\title{
SOURCES OF GEOLOGIC AND HYDROLOGIC INFORMATION PERTINENT TO GROUND-WATER RESOURCES IN RHODE ISLAND
}

\section{by Elaine C. Todd Trench}

U.S. GEOLOGICAL SURVEY

Open-File Report 93-464

Prepared in cooperation with the

RHODE ISLAND DEPARTMENT OF ENVIRONMENTAL MANAGEMENT

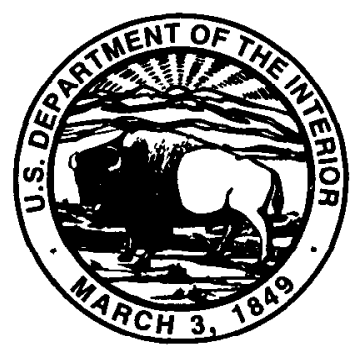

Providence, Rhode Island 1995

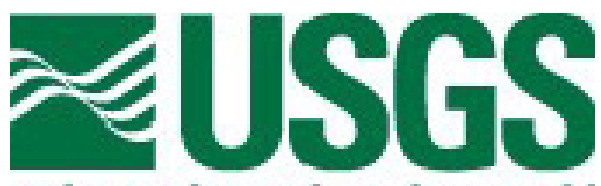




\section{SOURCES OF GEOLOGIC AND HYDROLOGIC INFORMATION PERTINENT TO GROUND-WATER RESOURCES IN RHODE ISLAND}

\section{by Elaine C. Todd Trench}

U.S. GEOLOGICAL SURVEY

Open-File Report 93-464

Prepared in cooperation with the

RHODE ISLAND DEPARTMENT OF ENVIRONMENTAL MANAGEMENT

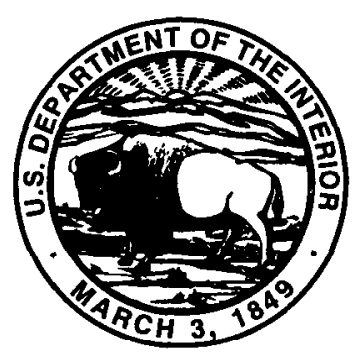

Providence, Rhode Island 1995 


\title{
U.S. DEPARTMENT OF THE INTERIOR \\ BRUCE BABBIT, Secretary
}

\author{
U.S. GEOLOGICAL SURVEY \\ Gordon P. Eaton, Director
}

For additional information, write to:

Subdistrict Chief

Massachusetts-Rhode Island District

U.S. Geological Survey

275 Promenade Street, Suite 150

Providence, Rl 02908
Copies of this report can be purchased from:

U.S. Geological Survey

Earth Science Information Center

Open-File Reports Section

Box 25286. MS 517

Denver Federal Center

Denver, CO 80225 


\section{CONTENTS}

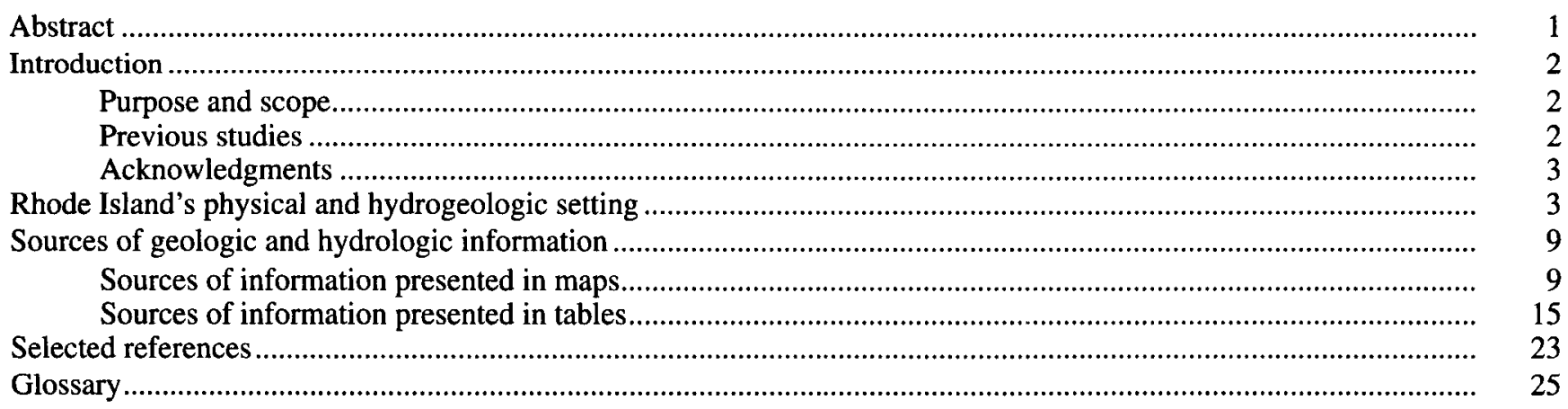

\section{FIGURES}

1,2. Maps showing:

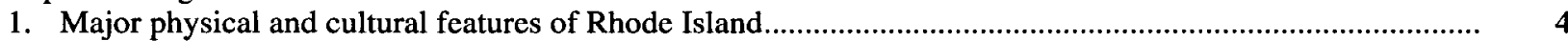

2. Rhode Island's major drainage basins, including basins shared with adjacent States ................................. 5

3,4. Block diagrams showing:

3. Generalized hydrologic cycle.

4. Typical hydrogeologic setting in glaciated terrain ................................................................................... 7

5-11. Maps of Rhode Island showing:

5. Distribution of ground-water reservoirs

6. Major drainage-basin boundaries and town lines.

7. Town lines and 7.5-minute quadrangle boundaries.

8. Availability of

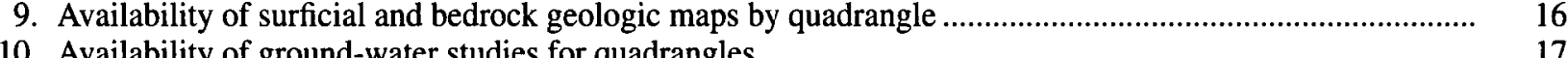

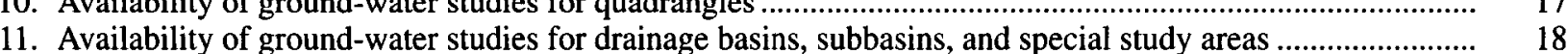

12. Map showing availability of ground-water studies for subbasins and special study areas in the Pawcatuck River Basin

\section{TABLES}

1. List of 7.5-minute topographic quadrangles covering Rhode Island, showing date of publication ....................... 9

2. List of Rhode Island cities and towns showing 7.5-minute quadrangles covering each municipality ................... 10

3. Types of geologic and hydrologic information for which sources are summarized in tables 4-40 for quadrangles in Rhode Island

4-40. Geologic and hydrologic information for Rhode Island quadrangles

4. Ashaway Quadrangle

5. Attleboro Quadrangle.

6. Blackstone Quadrangle.

7. Block Island Quadrangle ......

8. Bristol Quadrangle

9. Carolina Quadrangle.

10. Chepachet Quadrangle

11. Clayville Quadrangle...

12. Coventry Center Quadrangle

13. Crompton Quadrangle ....

14. East Greenwich Quadrangle

15. East Killingly Quadrangle ..

16. East Providence Quadrangle

17. Fall River Quadrangle 


\section{TABLES--Continued}

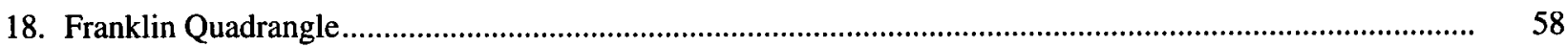

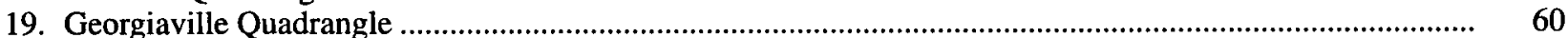

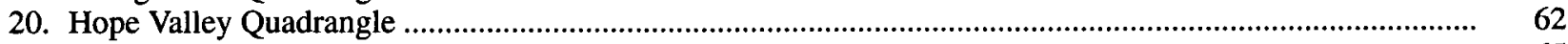

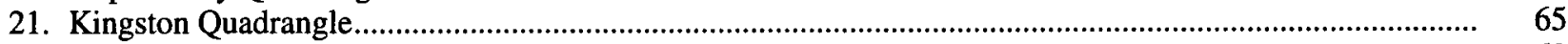

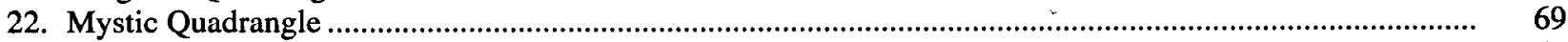

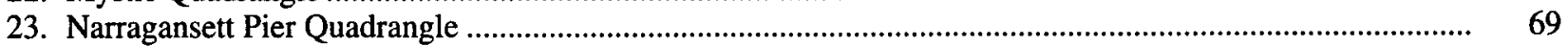

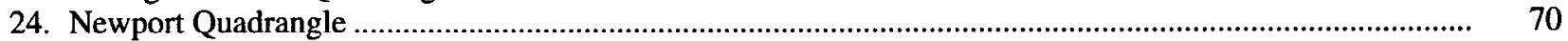

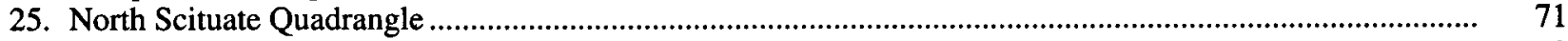

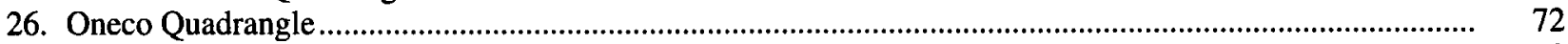

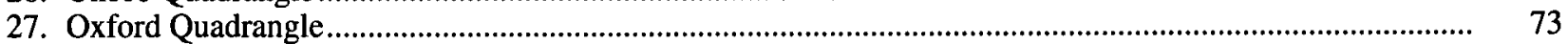

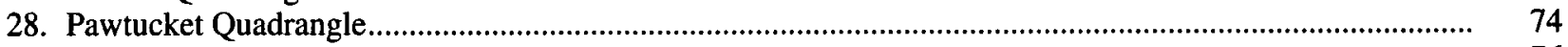

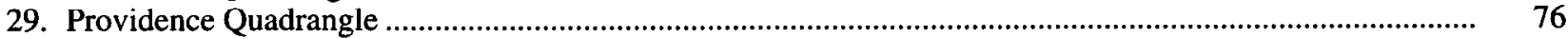

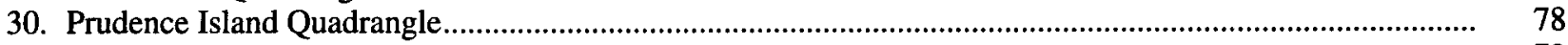

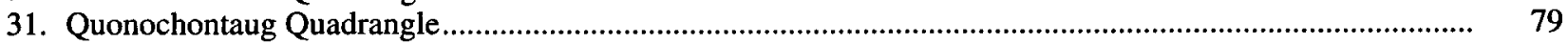

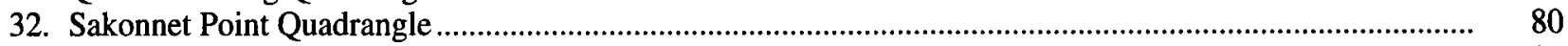

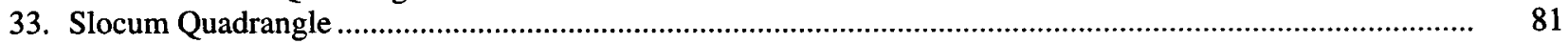

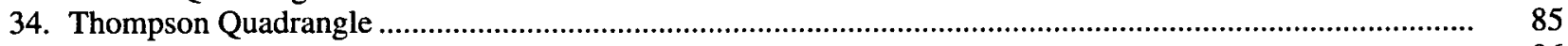

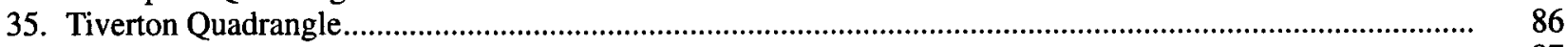

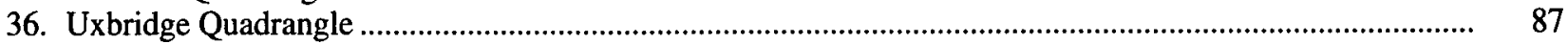

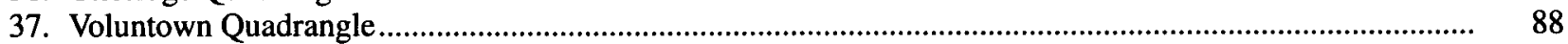

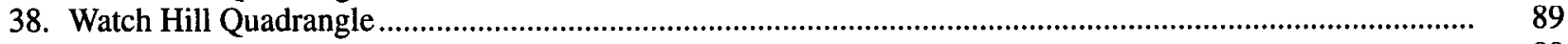

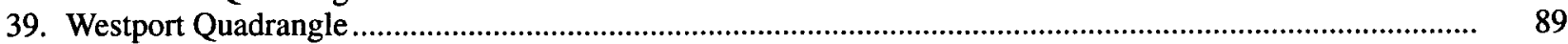

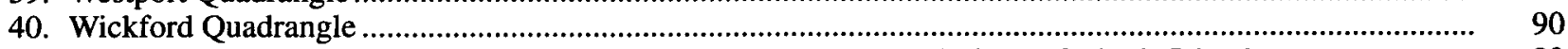

41. List of publications, by report series, pertaining to the geology and hydrology of Rhode Island..................... 


\section{CONVERSION FACTORS AND VERTICAL DATUM}

[Units of measure marked by an asterisk $\left(^{*}\right)$ are no longer in current usage, but are used in many of the older publications referenced in this report]

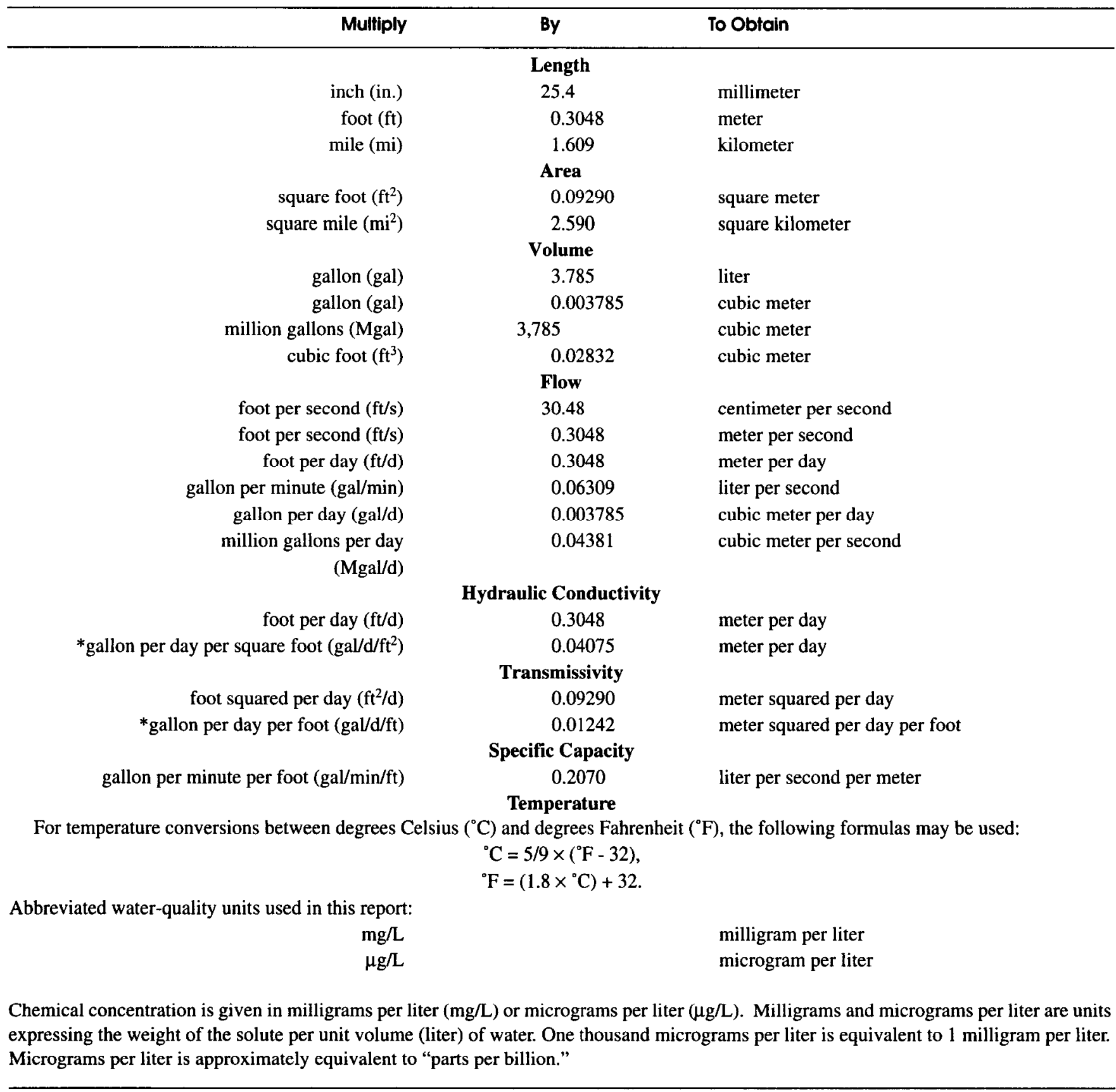

Sea Level: In this report "sea level" refers to the National Geodetic Vertical Datum of 1929 (NGVD of 1929)--a geodetic datum derived from a general adjustment of the first-order level nets of both the United States and Canada, formerly called Sea Level Datum of 1929. 


\title{
SOURCES OF GEOLOGIC AND HYDROLOGIC INFORMATION PERTINENT TO GROUND-WATER RESOURCES IN RHODE ISLAND
}

\author{
by Elaine $\mathrm{C}$. Todd Trench
}

\begin{abstract}
This report summarizes sources of geologic and hydrologic information useful to water managers and others involved in the investigation, appraisal, development, and protection of ground-water resources in Rhode Island. The geographic scope of the report includes Rhode Island and small adjoining areas of Massachusetts and Connecticut, where drainage basins are shared with these States. The information summarized is found in maps and reports prepared by the U.S. Geological Survey and published by either the U.S. Geological Survey or by the State of Rhode Island. Information sources are presented in maps and tables.

Reference maps show drainage divides, town lines, and the 7.5-minute grid of latitude and longitude for the State. Maps show availability of surficial geologic maps, bedrock geologic maps, and ground-water studies by 7.5minute quadrangle, and show availability of ground-water studies by drainage basin, subbasin, and special study area.
\end{abstract}

Sources of geologic and hydrologic information for the thirty-seven 7.5-minute quadrangles covering Rhode Island have been compiled based on the following information categories: surficial geology, bedrock geology, subsurface materials, altitude of bedrock surface, watertable altitudes, water-table contours, saturated thickness, hydraulic conductivity, transmissivity, drainage divides, recharge areas, ground-water reservoirs, induced infiltration, and ground-water quality. A table for each of the 37 quadrangles lists the major categories of information available for that quadrangle, provides references to the publications in which the information can be found, and indicates the format, scale, and other pertinent attributes of the information. A table organized by report series gives full citations for publications prepared by the U.S. Geological Survey pertaining to the geology and hydrology of Rhode Island. To facilitate location of information for particular municipalities, a table lists cities and towns in the State and the quadrangles that cover each municipality. 


\section{INTRODUCTION}

Ground water is an abundant resource in Rhode Island. In 1990, ground water supplied approximately 19 percent of the freshwater used for all purposes in the State, including domestic, industrial, and agricultural uses (Solley and others, 1993, p. 11, 25, 29). Ground water provided drinking water for 19 percent of the State's residents in 1990 . Public and private wells withdrew ground water from all the hydrogeologic settings of the State during the 1980's, in at least 35 of the State's 39 towns and cities. Ground water was the only source of drinking water for several towns.

Ground water in Rhode Island is generally suitable for human consumption and other uses that require high-quality water. However, ground-water contamination in Rhode Island and nationwide has increased public awareness of the risks to drinking-water supplies. Contaminants from a variety of sources have affected private and public ground-water supplies in Rhode Island. Most of the ground-water contamination in Rhode Island has been caused by human activities at or near the land surface.

Citizens understandably want drinking water resources to be protected from contamination. A technically sound ground-water protection program requires geologic and hydrologic information. Geologic and hydrologic information can be used to obtain understanding of hydrologic systems, identify significant aquifers, determine directions of ground-water flow, and identify land areas that provide recharge to aquifers or wells. In the area of ground-water quality, information can be used to define near-natural water-quality conditions, define existing problems, determine directions of contaminant movement, determine effects of land use, determine compliance with water-quality criteria and pollution control programs, and detect trends (S.M. Hindall, U.S. Geological Survey, written commun., 1985). The better the understanding of the ground-water system, the greater the likelihood that effective plans can be developed to protect ground water from contamination.

The Rhode Island Department of Environmental Management is the regulatory agency responsible for developing a ground-water protection program for the State. The mission of the U.S. Geological Survey is to collect, interpret, and disseminate geologic and hydrologic information that contributes to the wise management of the Nation's natural resources and promotes the well-being of its people (U.S. Geological Survey, 1986, p. 2). The complementary responsibilities of the Rhode Island Department of Environmental Management and the U.S. Geological Survey led to the cooperative project that has produced this report.

\section{Purpose and Scope}

The purpose of this report is to summarize available sources of geologic and hydrologic information useful to water managers and others involved in the investigation, appraisal, development, and protection of ground-water resources in Rhode Island. The geographic scope of the report includes Rhode Island and small adjoining areas of Massachusetts and Connecticut, where drainage basins are shared with these States. The information summarized is found in maps and reports prepared by the U.S. Geological Survey and published by either the U.S. Geological Survey or by the State of Rhode Island. Information sources are presented in maps and tables.

Information on the geology and hydrology of Rhode Island may be contained in studies of adjacent areas of Massachusetts or Connecticut. Reports dealing primarily with Massachusetts or Connecticut are not tabulated here. Interested readers may consult publication lists of U.S. Geological Survey offices or State water-resource agencies in those States.

\section{Previous Studies}

Principles of ground-water hydrology are described by Meinzer (1923, 1942), Baldwin and McGuinness (1963), Freeze and Cherry (1979), Todd (1980), Heath (1983), and Morrissey (1989). Hydrologic definitions are provided by Langbein and Iseri (1960) and Lohman and others (1972). Factors affecting ground-water quality are discussed by Johnston and Barlow (1988). The use of natural resources data in water-resources and land-use planning is discussed by Leopold and others (1971), Hill and Thomas (1972), Pessl and others (1972), and Harrison and Dickinson (1984). 
Statewide appraisals of ground-water availability in Rhode Island include reports by Allen (1953) and Lang (1961). A lay reader report on the ground-water resources of Rhode Island provides information on the occurrence, source, and movement of ground water in Rhode Island's hydrogeologic setting, and on major ground-water contamination problems in the State (Trench, 1991). Numerous statewide reports and reports for specific study areas in the State were consulted in the preparation of this report. These reports range in date from 1945 to 1993. In addition to the published studies inventoried in this report, unpublished data for some locations are available in the files of the Rhode Island Subdistrict Office, U.S. Geological Survey.

Under the ground-water protection program of the Rhode Island Department of Environmental Management, some of the geologic and hydrologic information summarized in the tables and maps of this report has been entered into the Rhode Island Geographic Information System, a computerized cartographic data base. Interested readers may contact the Rhode Island Department of Environmental Management to determine whether specific information is available through the Rhode Island Geographic Information System.

\section{Acknowledgments}

Margaret G. Dein Bradley and Ernest C. Panciera of the Rhode Island Department of Environmental Management Groundwater Section reviewed the report and provided information on agency responsibilities related to ground water.

Assistance in map compilation was provided by the Environmental Data Center in the Department of Natural Resources Science at the University of Rhode Island. The Environmental Data Center, under contract to the Rhode Island Department of Environmental Management, compiled information for the maps in the report through the Rhode Island Geographic Information System. Carol Pringle Baker, Groundwater Coordinator for the Rhode Island Geographic Information System at the Environmental Data Center, was most helpful and resourceful in developing these illutrations.
Special thanks are extended to Lisa J. Sosa, Brown University, and Scott Graham, University of Rhode Island, who made an important contribution in compiling information for the tables in this report during their student internships in the Rhode Island Office of the U.S. Geological Survey.

\section{RHODE ISLAND'S PHYSICAL AND HYDROGEOLOGIC SETTING}

Rhode Island (fig. 1) is in southeastern New England and has a land area of 1,045 square miles. The State lies within two major physiographic sections of the New England province described by Fenneman (1938). The northwestern part of the State is in the hilly New England Upland section. Southern and eastern parts of the State are in the Seaboard Lowland section, an area of flat or gently rolling land that includes coastal areas, Narragansett Bay, and the Bay islands (fig. 1). Altitudes in the State range from sea level along the coast to a maximum of 812 feet at Jerimoth Hill in the northwestern part of the State (fig. 1).

The climate of Rhode Island is humid and temperate. Most parts of the State usually receive at least 40 inches of rain annually. For the period 1954 to 1983, the average annual precipitation across the State ranged from 41 to 53 inches (R.W. Bell, U.S. Geological Survey, written commun., 1987). Hilly areas in the northwestern part of the State receive larger amounts of precipitation than coastal areas.

Surface water and ground water are both plentiful resources in Rhode Island. The boundaries of Rhode Island's major drainage basins show the regional framework of Rhode Island's water resources (fig. 2). In some areas, surface water and ground water from neighboring areas of Massachusetts and Connecticut flow into Rhode Island. In other areas, surface water and ground water from Rhode Island flow into Massachusetts and Connecticut.

Ground water is present below the land surface everywhere in Rhode Island, although the quantity available for use differs considerably from place to place. Ground-water flow in Rhode Island is part of 


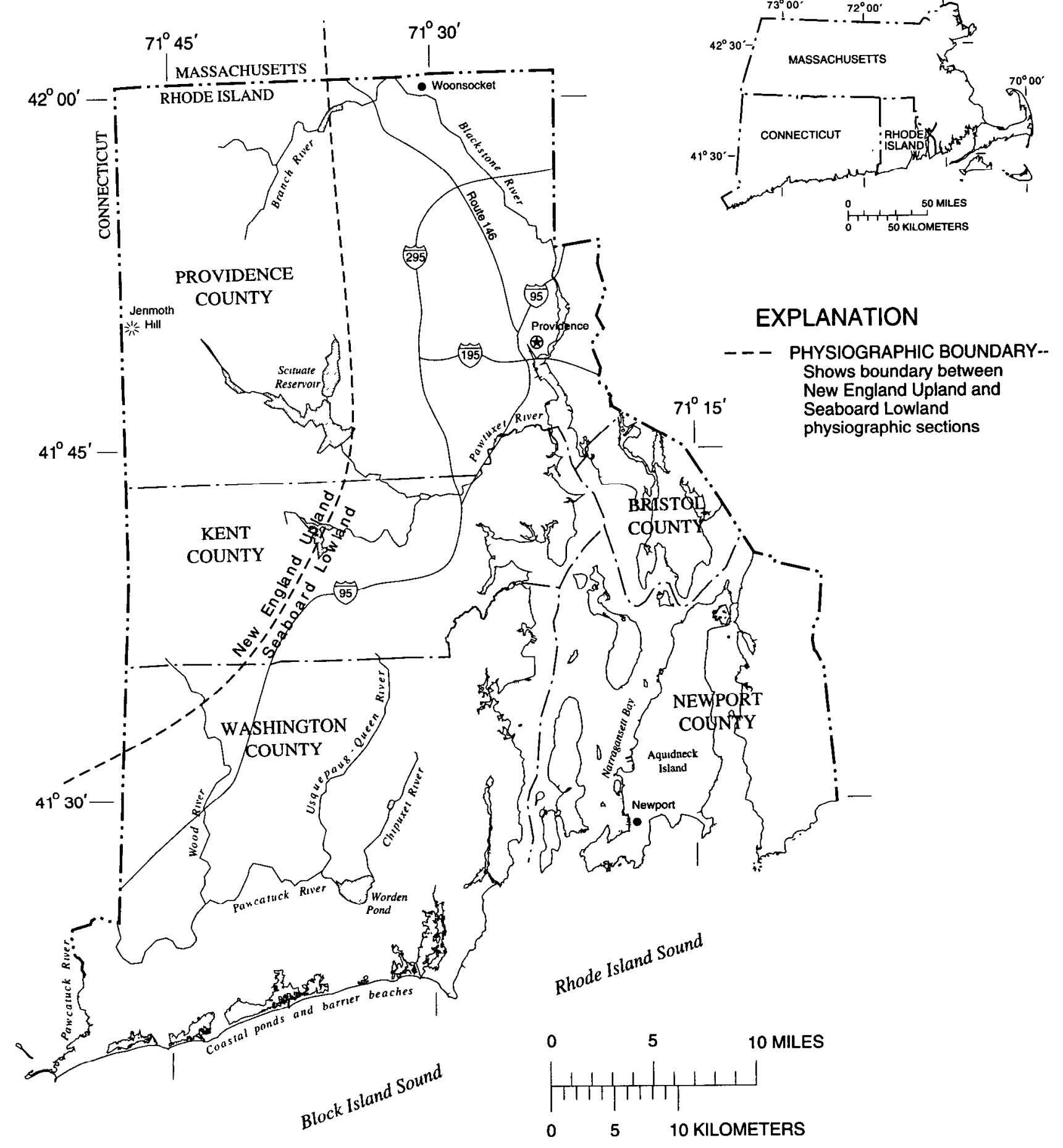

Base from U S. Geological Survey digital data, 1:100,000, 1983 Universal Transverse Mercator Projection Zone 19

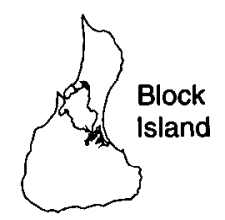

Figure 1. Major physical and cultural features of Rhode Island. (Source: Boundary between New England Upland and Seaboard Lowland from Fenneman, 1938, pl. 1.) 


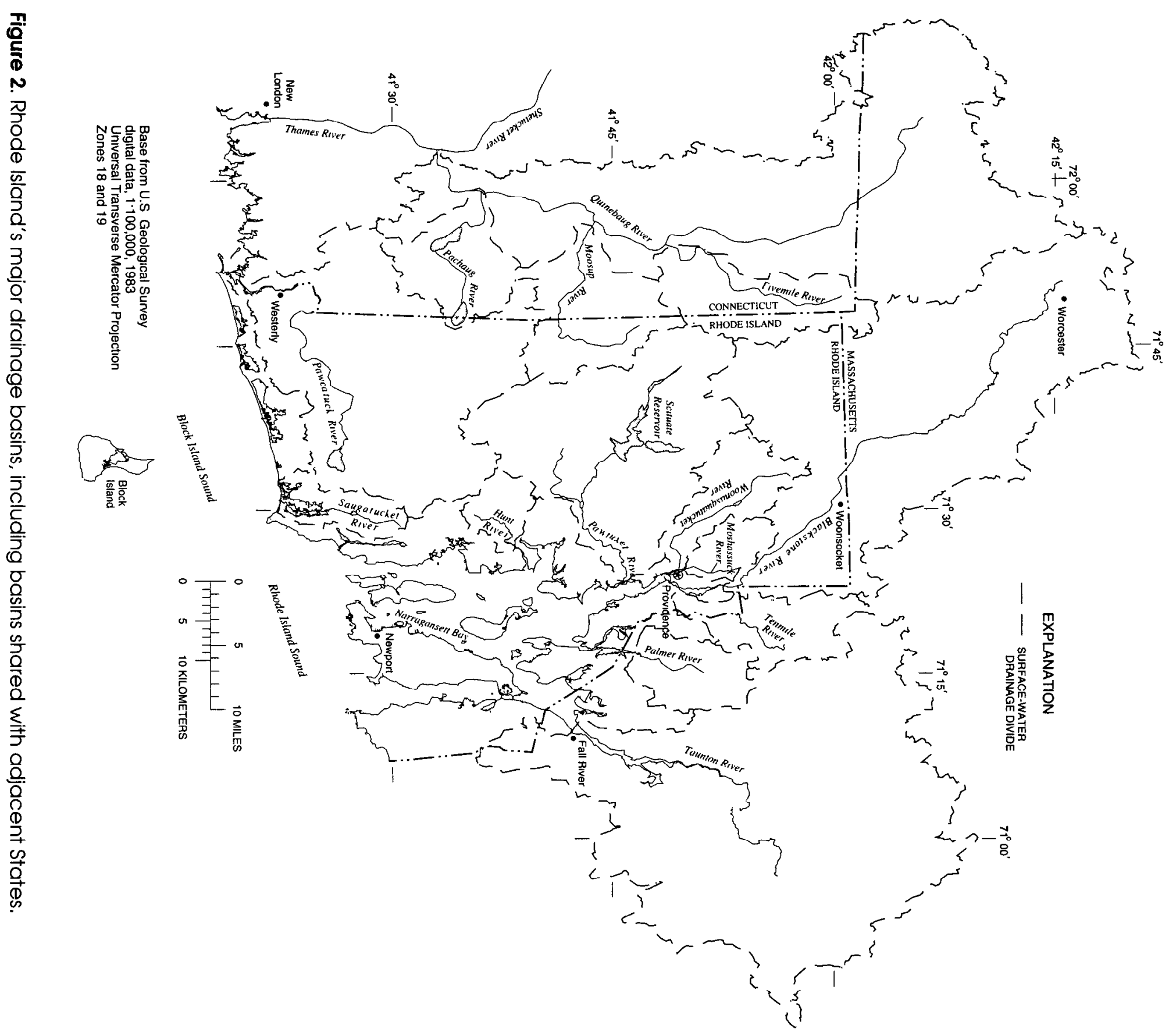


the planetary circulation of water known as the hydrologic cycle (fig. 3). Ground water flows slowly through the small pore spaces in unconsolidated materials and the joints and fractures in bedrock. The general direction of ground-water flow is from highlands toward nearby stream valleys or toward the coast (figs. 3, 4). Rhode Island's surface water and ground water are interconnected bodies of freshwater.

All of Rhode Island, with the exception of Block Island (fig. 1), is part of the Northeast and Superior Uplands ground-water region, which includes most of New England and parts of other northeastern States (Heath, 1984, p. 48). In this region, unconsolidated glacial deposits overlie fractured bedrock (fig. 4). Ground water is found in both the glacial deposits and the underlying bedrock, which form an interconnected aquifer system.
Block Island is part of the Atlantic and Gulf Coastal Plain ground-water region (Heath, 1984, p. 52). Glacial sediments on Block Island were deposited on thick layers of older unconsolidated and semiconsolidated coastal plain sediments. These sediments in turn overlie the bedrock, which is about 1,000 feet below sea level near Block Island (Hansen and Schiner, 1964, p. 7).

Glacial deposits in Rhode Island include till, stratified drift, and mixed deposits of till and stratified drift. Till is the most extensive glacial deposit in Rhode Island, as in the rest of the glaciated northeastern United States. The thickness of the till ranges from a few inches to as much as 100 feet, and averages about 20 feet. Stratified-drift deposits fill most major stream valleys and many tributary stream valleys (fig. 4), and form extensive sandy lowlands in some coastal areas. Stratified-drift deposits cover about

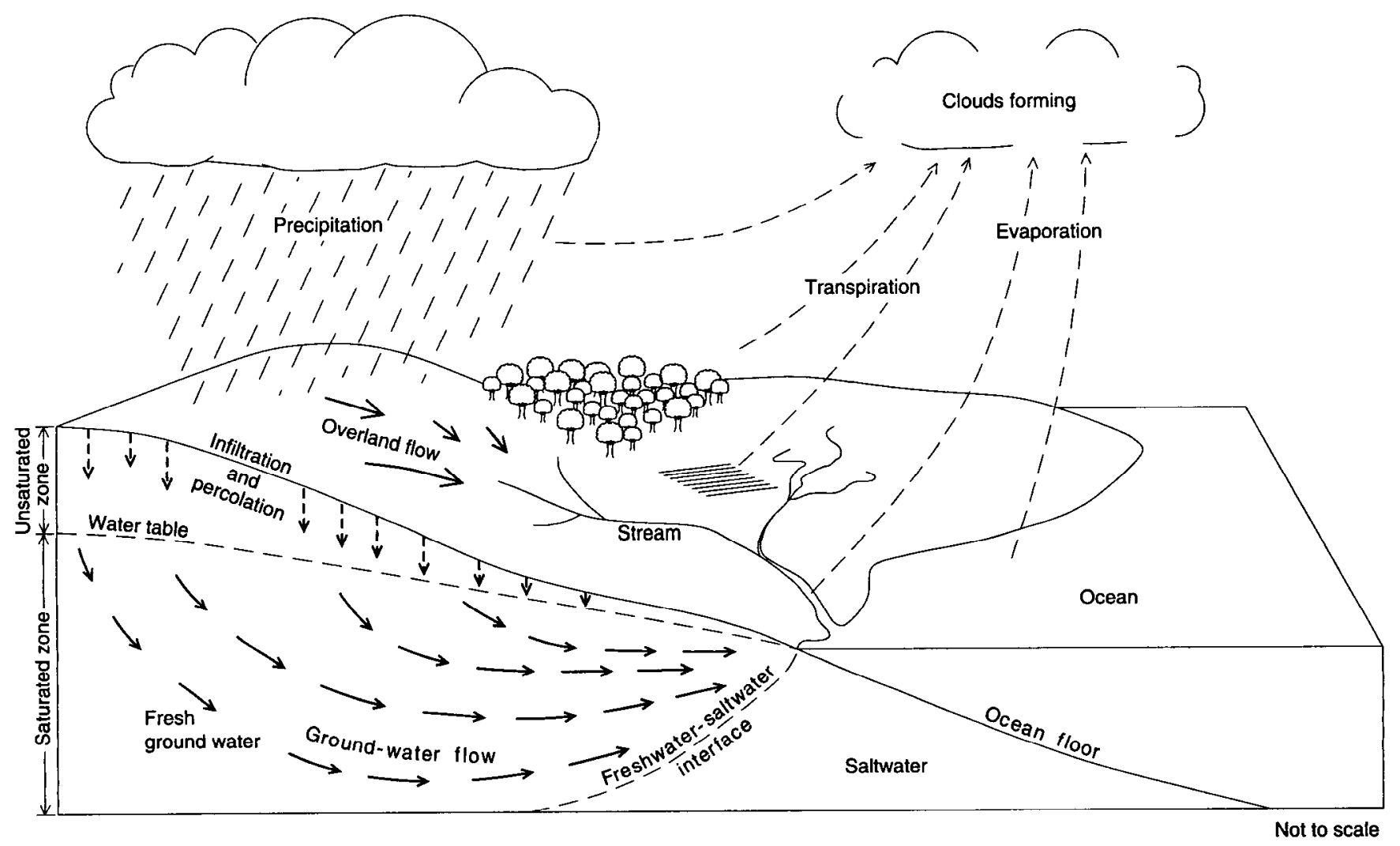

Figure 3. Generalized hydrologic cycle. Arrows show movement of water and water vapor. (Modified from Heath, 1983, p. 5.) 


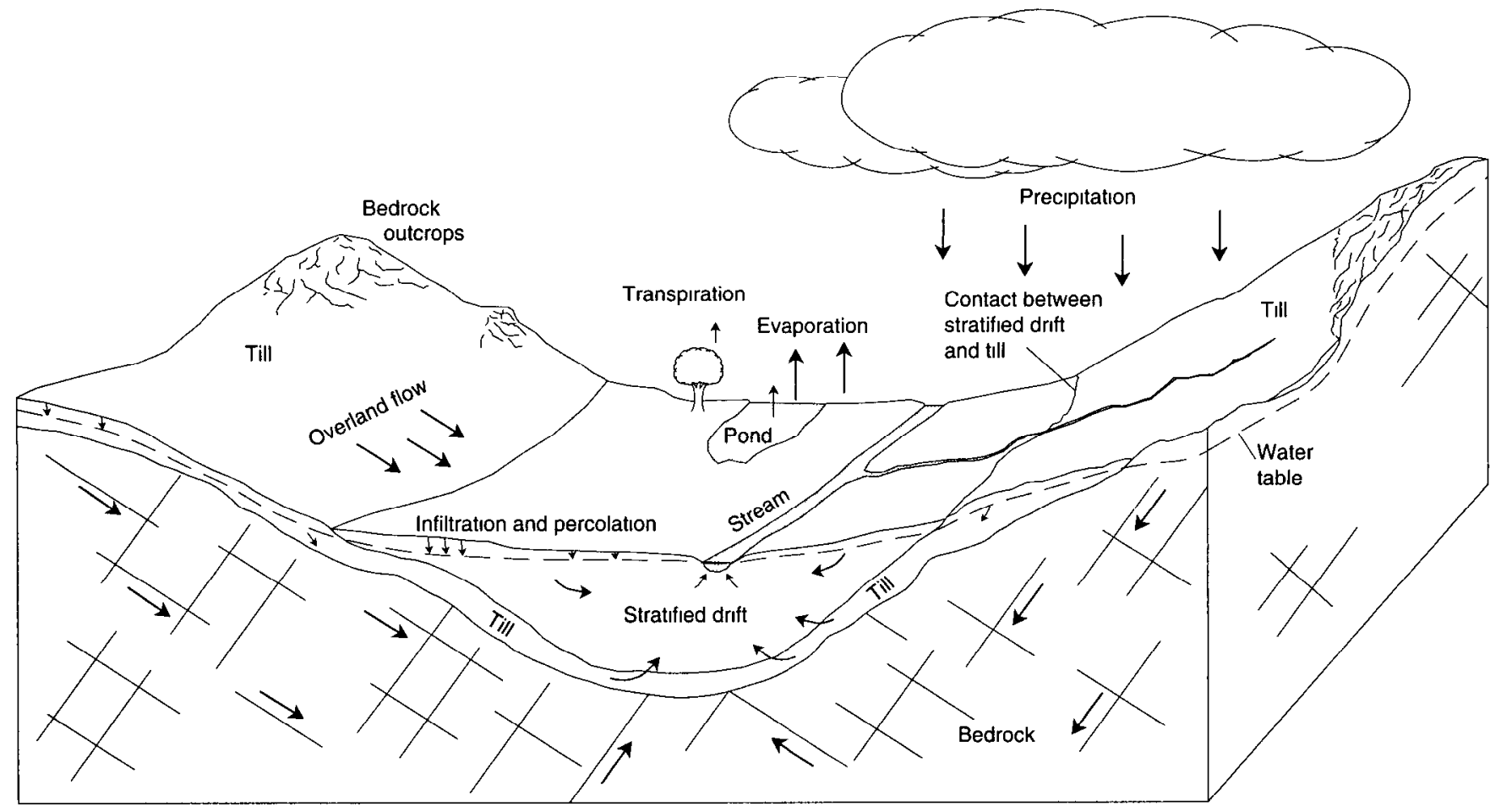

Not to scale

Figure 4. Typical hydrogeologic setting in glaciated terrain. Unconsolidated glacial deposits overlie fractured bedrock. Till blankets the bedrock surface and is exposed at the land surface in upland areas. Till generally underlies the stratified drift that fills bedrock valleys. Arrows indicate directions of flow or movement of water and water vapor. (Modified from Trench and Morrissey, 1985, p. 4, fig. 1.)

one-third of the State's land surface. Thick deposits of coarse-grained stratified drift form the State's most important aquifers.

The term "ground-water reservoir" is often used to refer to stratified-drift aquifers with the greatest potential for development. The Rhode Island Water Resources Board has identified 21 stratified-drift aquifers that have the best potential of all aquifers in the State for yielding large amounts of water (fig. 5). These high-yield aquifers are termed "ground-water reservoirs" by the State.

Major public-supply wells tap many of the ground-water reservoirs. Some ground-water reservoirs have been investigated more intensively than others, and the acquisition of new data could alter the boundaries of ground-water reservoirs shown in figure 5. The ground-water reservoirs represent only a small part of the total area underlain by stratified drift.

Till, although widespread geographically, is not used for public water supplies and is used for few private supply wells because of its generally low permeability and limited saturated thickness. Bedrock is the most extensive aquifer in the State, and the most common source of water in rural areas not served by public water supplies. At least small quantities of ground water are available virtually everywhere in the State, and ground water is withdrawn from all the major geologic units. 


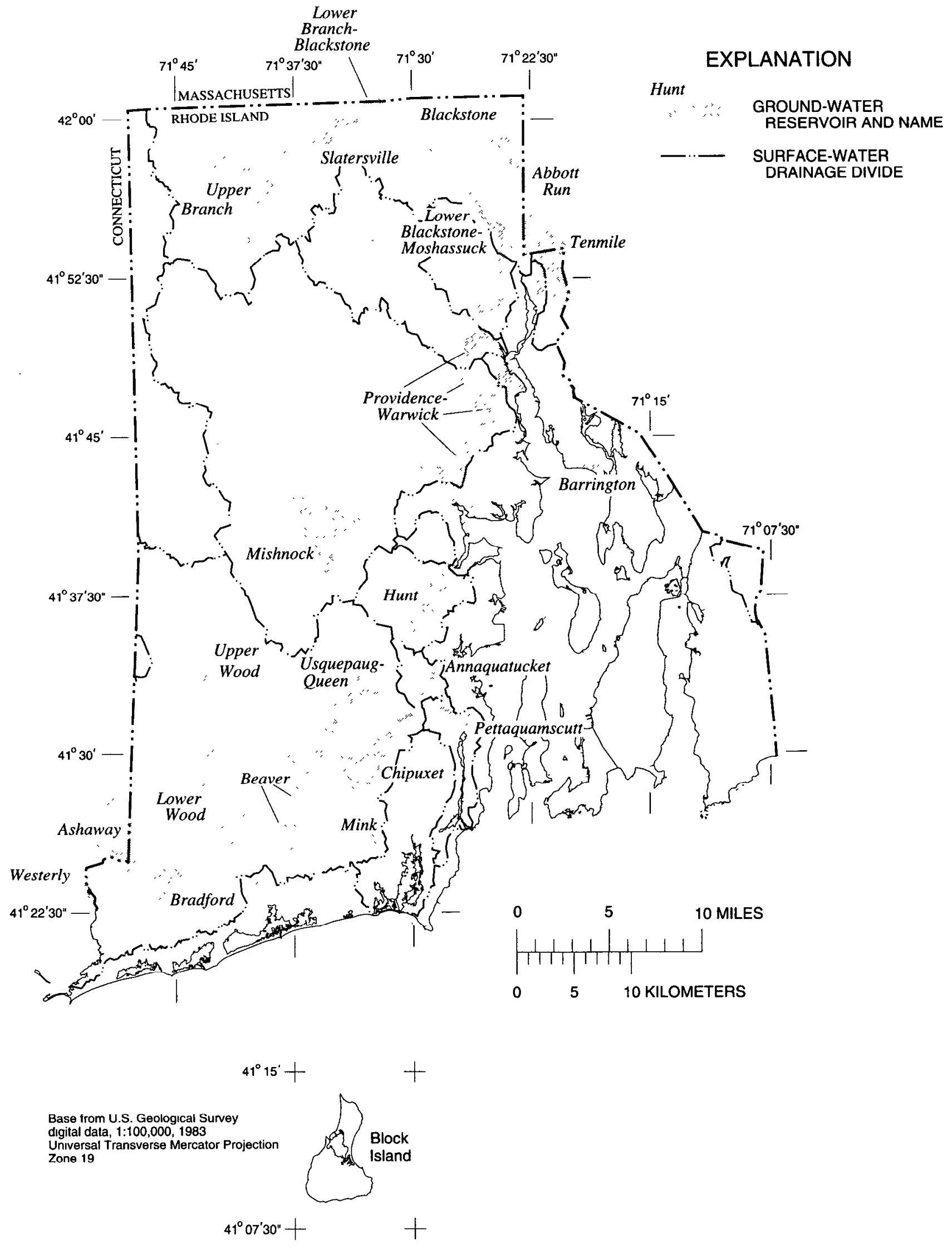

Figure 5. Distribution of ground-water reservoirs in Rhode Island. (Source for boundaries of ground-water reservoirs: W.B. Allen, Rhode Island Water Resources Board, written commun., 1978; modified by Rhode Island Department of Environmental Management, 1988.) 


\section{SOURCES OF GEOLOGIC AND HYDROLOGIC INFORMATION}

Sources of geologic and hydrologic information for Rhode Island have been summarized in maps and tables for this report. Information has been compiled primarily by 7.5 -minute quadrangle or by drainage basin, because these have been the most commonly used study area boundaries for geologic and hydrologic investigations. Some studies using political or other arbitrary boundaries are also included in this inventory.

Several report series on the geology and hydrology of Rhode Island are based on the boundaries of the U.S. Geological Survey's 7.5-minute topographic quadrangle map series. An alphabetical list of the 37 topographic quadrangles that cover Rhode Island is shown in table 1. To facilitate location of information for particular municipalities, table 2 includes an alphabetical list of cities and towns in Rhode Island and a list of the quadrangles that cover each municipality.

\section{Sources of Information Presented in Maps}

Maps in this report are intended to provide a quick pictorial summary of information available for different parts of the State. Boundaries shown on maps include drainage divides for major drainage basins or subbasins, the 7.5-minute grid of latitude and longitude covering the State (also referred to as USGS quadrangle boundaries) and (or) town lines. Town lines are shown to help local decisionmakers locate information for specific cities and towns. On maps where the complete quadrangle grid is not shown, latitude and longitude tick marks are shown at 7.5-minute intervals along the borders so that readers can locate USGS quadrangle maps of interest.

Drainage divides and town lines are shown in figure 6 , the quadrangle grid and town lines are shown in figure 7 , and drainage divides and the quadrangle grid are shown in figure 8 . These three maps provide the geographic reference material for other maps and tables showing the availability of publications for different quadrangles or drainage basins. Note in figures 7 and 8 that the coastal Kingston, Narragansett Pier, and Westport quadrangles extend beyond the standard 7.5 minutes of latitude.
Table 1. List of 7.5-minute topographic quadrangles covering Rhode Island, showing date of publication

[Scale 1:24,000. Quadrangles marked with an asterisk $\left({ }^{*}\right)$ are also available at 1:25,000. Source: U.S. Geological

Survey, 1987, p. 11-12]

\begin{tabular}{|c|c|}
\hline Quadrangle & Date \\
\hline 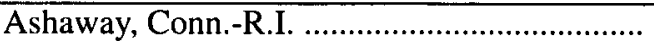 & 1975 \\
\hline Attleboro, Mass.-R.I.*. & 1979 \\
\hline Blackstone, Mass.-R.I. $* . . . . . . . . . .$. & 1979 \\
\hline Block Island, R.I. & 1970 \\
\hline 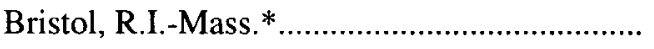 & 1975 \\
\hline 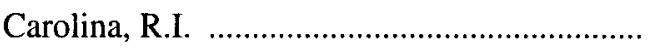 & 1970 \\
\hline 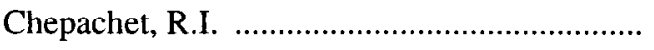 & 1975 \\
\hline Clayville, R.I. & 1970 \\
\hline Coventry Center, R.I. & 1970 \\
\hline Crompton, R.I. ....................... & 1970 \\
\hline East Greenwich, R.I. ................ & 1975 \\
\hline East Killingly, Conn.-R.I. ......... & 1974 \\
\hline East Providence, R.I.-Mass. * ................................. & 1979 \\
\hline Fall River, Mass.-R.I. & 1979 \\
\hline Franklin, Mass.-R.I.*................. & 1979 \\
\hline Georgiaville, R.I. & 1975 \\
\hline Hope Valley, R.I. & 1970 \\
\hline 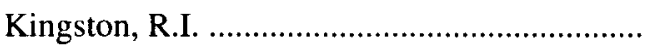 & 1975 \\
\hline 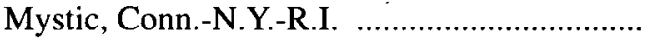 & 1984 \\
\hline 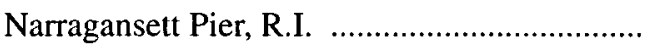 & 1975 \\
\hline 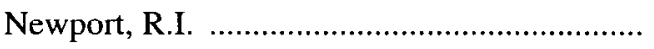 & 1970 \\
\hline North Scituate, R.I. & 1975 \\
\hline 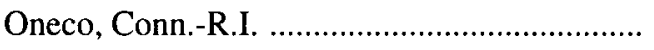 & 1970 \\
\hline 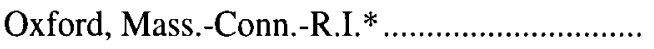 & 1979 \\
\hline 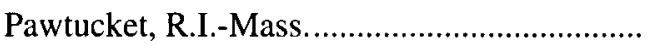 & 1975 \\
\hline Providence, R.I. . & 1975 \\
\hline Prudence Island, R.I. & 1975 \\
\hline Quonochontaug, R.I. .......... & 1970 \\
\hline Sakonnet Point, R.I. ............ & 1970 \\
\hline Slocum, R.I. ......................... & 1970 \\
\hline 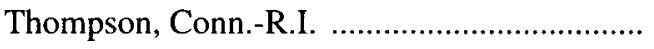 & 1970 \\
\hline 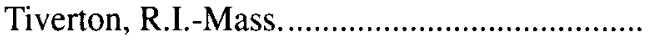 & 1975 \\
\hline 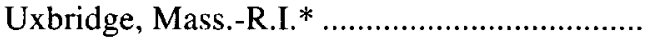 & 1969 \\
\hline Voluntown, Conn.-R.I. & 1975 \\
\hline Watch Hill, R.I.-Conn. & 1984 \\
\hline 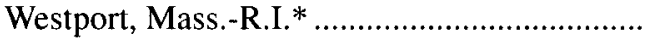 & 1977 \\
\hline Wickford, R.I. . & 1975 \\
\hline
\end{tabular}


Table 2. List of Rhode Island cities and towns showing 7.5-minute quadrangles covering each municipality

\begin{tabular}{|c|c|c|c|}
\hline Municipality & Quadrangle & Municipality & Quadrangle \\
\hline Barrington & $\begin{array}{l}\text { Bristol } \\
\text { East Providence }\end{array}$ & Hopkinton & $\begin{array}{l}\text { Ashaway } \\
\text { Carolina } \\
\text { Hope Valley }\end{array}$ \\
\hline Bristol & $\begin{array}{l}\text { Bristol } \\
\text { Fall River }\end{array}$ & & Voluntown \\
\hline \multirow[t]{2}{*}{ Burrillville } & $\begin{array}{l}\text { Blackstone } \\
\text { Chepachet } \\
\text { Georgiaville } \\
\text { Oxford }\end{array}$ & Jamestown & $\begin{array}{l}\text { Narragansett Pier } \\
\text { Newport } \\
\text { Prudence Island } \\
\text { Wickford }\end{array}$ \\
\hline & $\begin{array}{l}\text { Thompson } \\
\text { Uxbridge }\end{array}$ & Johnston & $\begin{array}{l}\text { North Scituate } \\
\text { Providence }\end{array}$ \\
\hline Central Falls & Pawtucket & Lincoln & $\begin{array}{l}\text { Pawtucket } \\
\text { Providence }\end{array}$ \\
\hline Charlestown & $\begin{array}{l}\text { Carolina } \\
\text { Kingston } \\
\text { Quonochontaug }\end{array}$ & Little Compton & $\begin{array}{l}\text { Sakonnet Puint } \\
\text { Tiverton } \\
\text { Westport }\end{array}$ \\
\hline Coventry & $\begin{array}{l}\text { Coventry Center } \\
\text { Crompton } \\
\text { Oneco }\end{array}$ & Middletown & $\begin{array}{l}\text { Newport } \\
\text { Prudence Island } \\
\text { Sakonnet Point }\end{array}$ \\
\hline \multirow[t]{2}{*}{ Cranston } & $\begin{array}{l}\text { Crompton } \\
\text { East Greenwich }\end{array}$ & & Tiverton \\
\hline & $\begin{array}{l}\text { North Scituate } \\
\text { Providence }\end{array}$ & Narragansett & $\begin{array}{l}\text { Kingston } \\
\text { Narragansett Pier } \\
\text { Wickford }\end{array}$ \\
\hline Cumberland & $\begin{array}{l}\text { Franklin } \\
\text { Pawtucket }\end{array}$ & New Shoreham & Block Island \\
\hline \multirow[t]{2}{*}{ East Greenwich } & $\begin{array}{l}\text { Crompton } \\
\text { East Greenwich }\end{array}$ & Newport & $\begin{array}{l}\text { Newport } \\
\text { Prudence Island }\end{array}$ \\
\hline & $\begin{array}{l}\text { Slocum } \\
\text { Wickford }\end{array}$ & North Kingstown & $\begin{array}{l}\text { East Greenwich } \\
\text { Kingston }\end{array}$ \\
\hline East Providence & $\begin{array}{l}\text { Bristol } \\
\text { East Providence } \\
\text { Providence }\end{array}$ & & $\begin{array}{l}\text { Narragansett Pier } \\
\text { Slocum } \\
\text { Wickford }\end{array}$ \\
\hline Exeter & $\begin{array}{l}\text { Hope Valley } \\
\text { Slocum }\end{array}$ & North Providence & $\begin{array}{l}\text { Pawtucket } \\
\text { Providence }\end{array}$ \\
\hline \multirow[t]{2}{*}{ Foster } & $\begin{array}{l}\text { Voluntown } \\
\text { Clayville } \\
\text { Coventry Center }\end{array}$ & North Smithfield & $\begin{array}{l}\text { Blackstone } \\
\text { Georgiaville } \\
\text { Pawtucket }\end{array}$ \\
\hline & $\begin{array}{l}\text { East Killingly } \\
\text { Oneco }\end{array}$ & Pawtucket & $\begin{array}{l}\text { Attleboro } \\
\text { East Providence }\end{array}$ \\
\hline \multirow[t]{2}{*}{ Glocester } & $\begin{array}{l}\text { Chepachet } \\
\text { Clayville }\end{array}$ & & $\begin{array}{l}\text { Pawtucket } \\
\text { Providence }\end{array}$ \\
\hline & $\begin{array}{l}\text { East Killingly } \\
\text { Georgiaville } \\
\text { North Scituate } \\
\text { Thompson }\end{array}$ & Portsmouth & $\begin{array}{l}\text { Bristol } \\
\text { Fall River } \\
\text { Prudence Island } \\
\text { Tiverton }\end{array}$ \\
\hline
\end{tabular}


Table 2. List of Rhode Island cities and towns showing 7.5-minute quadrangles covering each municipality--Continued

\begin{tabular}{|c|c|c|c|}
\hline Municipality & Quadrangle & Municipality & Quadrangle \\
\hline Providence & Providence & Warwick & Bristol \\
\hline \multirow[t]{2}{*}{ Richmond } & $\begin{array}{l}\text { Carolina } \\
\text { Hope Valley } \\
\text { Kingston }\end{array}$ & & $\begin{array}{l}\text { Crompton } \\
\text { East Greenwich } \\
\text { Providence }\end{array}$ \\
\hline & Slocum & West Greenwich & Coventry Center \\
\hline Scituate & $\begin{array}{l}\text { Clayville } \\
\text { Coventry Center } \\
\text { Crompton } \\
\text { North Scituate }\end{array}$ & & $\begin{array}{l}\text { Crompton } \\
\text { Hope Valley } \\
\text { Oneco } \\
\text { Slocum } \\
\text { Voluntown }\end{array}$ \\
\hline Smithfield & $\begin{array}{l}\text { Georgiaville } \\
\text { North Scituate } \\
\text { Pawtucket }\end{array}$ & West Warwick & $\begin{array}{l}\text { Crompton } \\
\text { East Greenwich }\end{array}$ \\
\hline South Kingstown & $\begin{array}{l}\text { Providence } \\
\text { Kingston } \\
\text { Narragansett Pier } \\
\text { Slocum }\end{array}$ & Westerly & $\begin{array}{l}\text { Ashaway } \\
\text { Carolina } \\
\text { Mystic } \\
\text { Quonochontaug } \\
\text { Watch Hill }\end{array}$ \\
\hline Tiverton & $\begin{array}{l}\text { Fall River } \\
\text { Tiverton }\end{array}$ & Woonsocket & $\begin{array}{l}\text { Blackstone } \\
\text { Franklin }\end{array}$ \\
\hline Warren & $\begin{array}{l}\text { Bristol } \\
\text { East Providence } \\
\text { Fall River }\end{array}$ & & $\begin{array}{l}\text { Georgiaville } \\
\text { Pawtucket }\end{array}$ \\
\hline
\end{tabular}




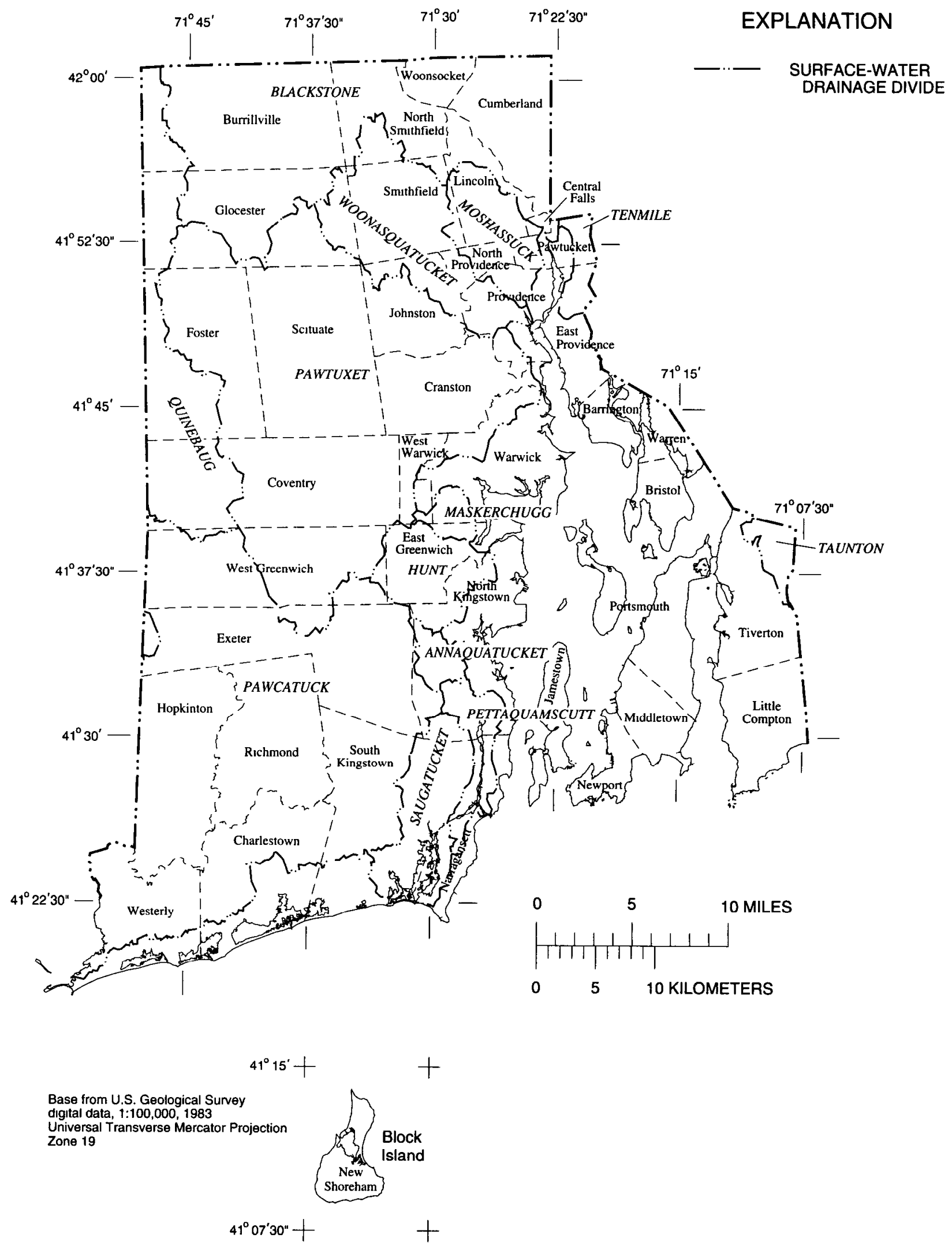

Figure 6. Major drainage basin boundaries and town lines in Rhode Island. 


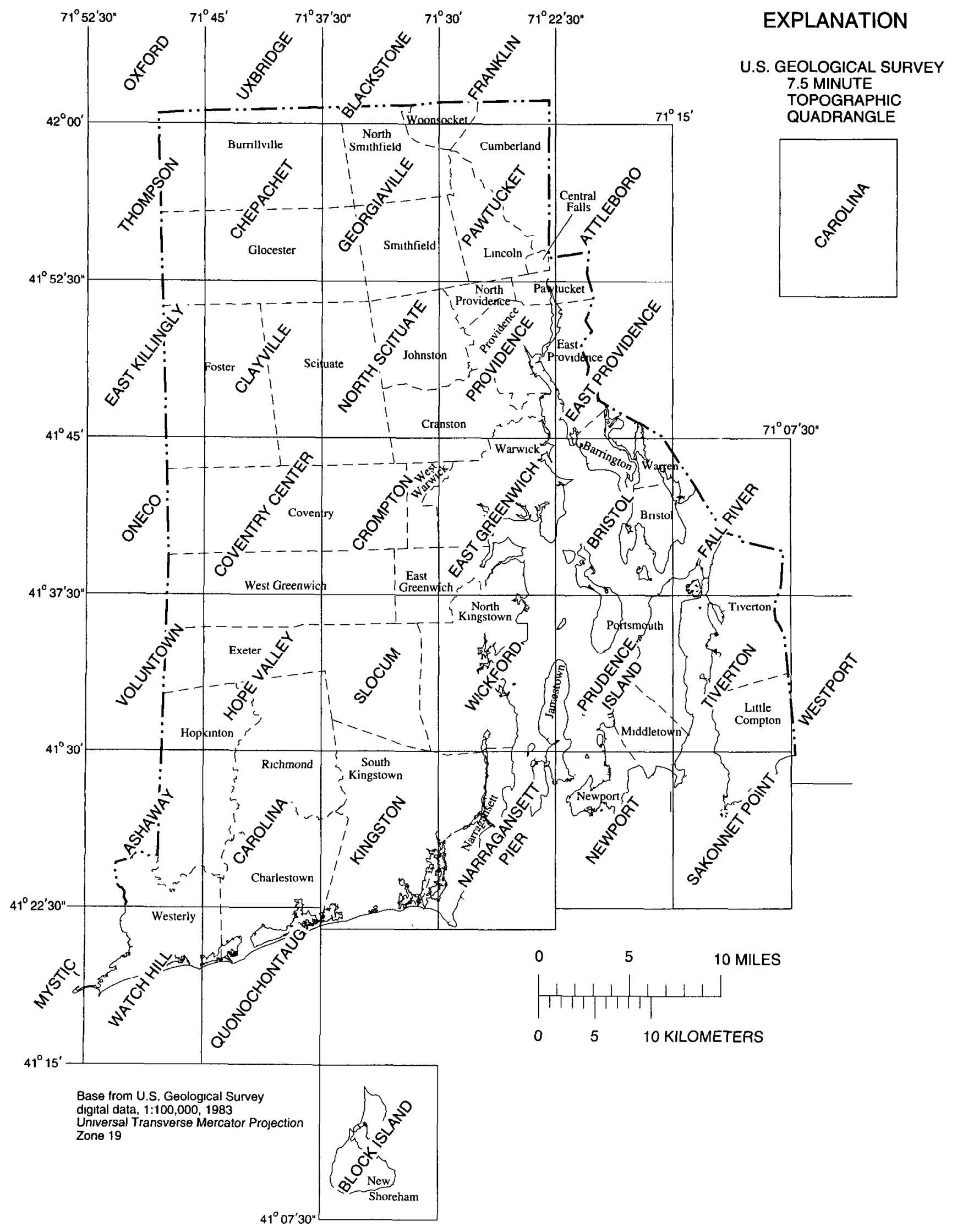

Figure 7. Town lines and 7.5-minute quadrangle boundaries in Rhode Island. Dates for topographic quadrangle maps shown in table 1 . 


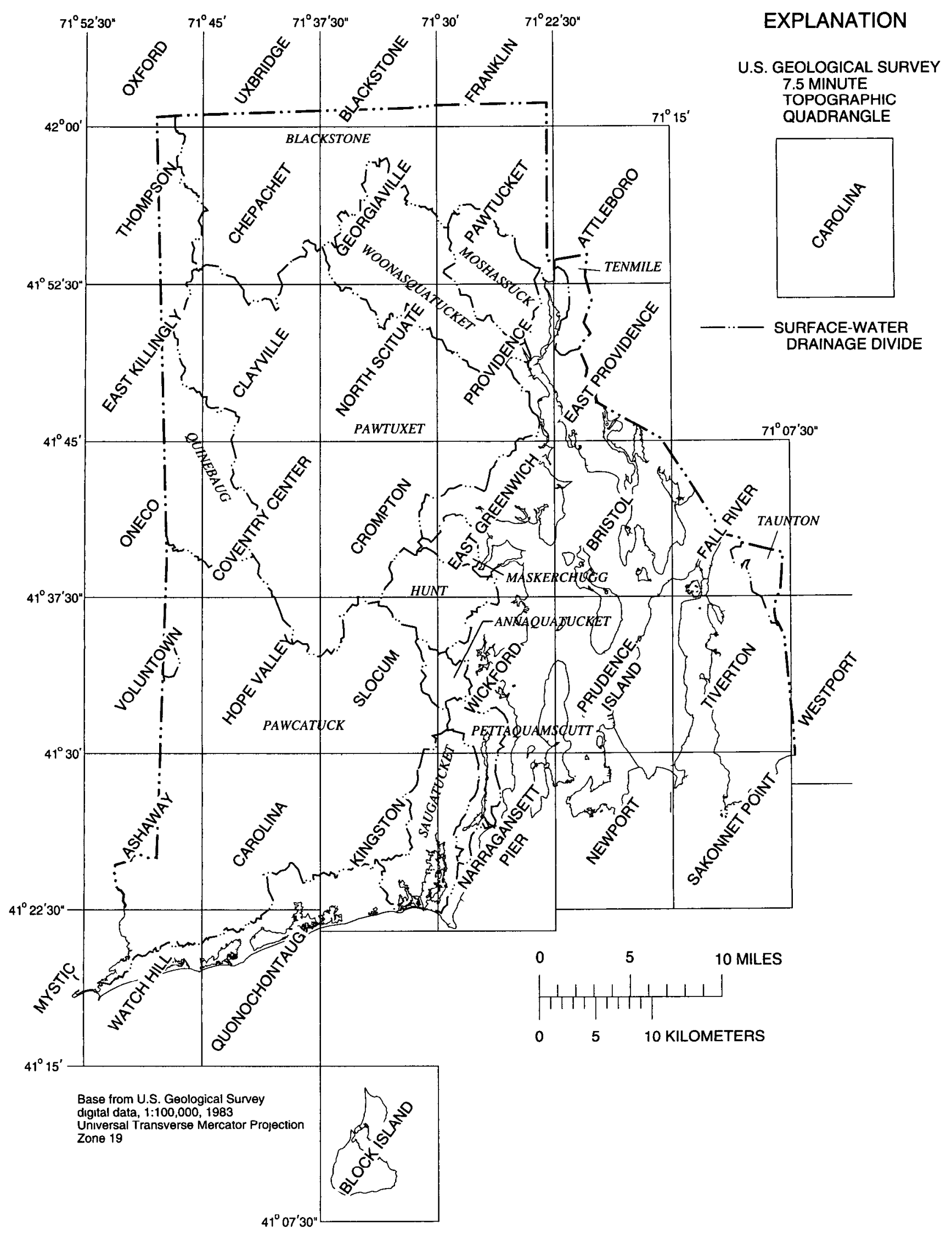

Figure 8. Major drainage basin boundaries and 7.5-minute quadrangle boundaries in Rhode Island. Dates for topographic quadrangle maps shown in table 1. 
Availability of surficial and bedrock geologic maps by quadrangle is shown in figure 9 . Geologic maps have been published by the U.S. Geological Survey in the Bulletin series (B), the Geologic Quadrangle series (GQ), or the Open-File Report series (OFR). The Bulletin series is published in a book format along with map plates, whereas the Geologic Quadrangle series is published in map format. All three series have used the quadrangle grid for geologic map boundaries in Rhode Island.

The Hope Valley quadrangle and the town of West Greenwich provide an example of the use of figure 9, in conjunction with figures 7 and 8 . Figure 9 shows that both a surficial and a bedrock geologic map are available for the Hope Valley quadrangle. Figure 7 shows that geologic maps for the Hope Valley quadrangle provide information for parts of the towns of West Greenwich, Exeter, Hopkinton, and Richmond. Figure 8 shows that the geologic maps encompass a large part of the Pawcatuck River Basin and a small corner of the southern part of the Pawtuxet River Basin. If information on surficial geology is required for the town of West Greenwich, figure 7 shows that maps for six quadrangles are needed: Oneco, Coventry Center, Crompton, Voluntown, Hope Valley, and Slocum. Figure 9 shows that surficial maps are available for each of these quadrangles except Coventry Center.

Availability of ground-water studies by quadrangle is shown in figure 10. The State of Rhode Island published ground-water studies by quadrangle in the Geologic Bulletin series (GB) and the Ground-Water Map series (GWM) from 1945 to 1964. The two series, which do not overlap geographically, are general areal reconnaissance studies. The older Geologic Bulletin series includes text in a book format as well as map plates, whereas the Ground-Water Map series is in map format only. The maps show the contact between till and stratified drift, water-table and bedrock-surface altitudes at selected wells, and generalized water-table contours and bedrock contours in some areas. Again using the town of West Greenwich (fig. 7) as an example, figure 10 shows that ground-water maps are available for the six quadrangles-Oneco, Coventry Center, Crompton, Voluntown, Hope Valley, and Slocumcovering that town.
Figure 11 shows availability of ground-water studies for drainage basins, subbasins, and special study areas in Rhode Island. Information on studics within the Pawcatuck River Basin, where there have been numerous investigations, is shown in more detail in figure 12. Most of the study areas shown in figures 11 and 12 are bounded by drainage divides. Some study area boundaries also include political or arbitrary boundaries.

An approximate indication of towns covered by basin studies can be obtained by use of figure 11 in conjunction with figure 6 . For example, figure 6 shows that the town of Cumberland is within the Blackstone River Basin. Reports listed for the Blackstone River area in figure 11 cover an area of northeastern Rhode Island that includes the town of Cumberland.

Report series shown in figures 11 and 12 include series published by the U.S. Geological Survey and the State of Rhode Island over a period of several decades. The series are varied in content, including geohydrologic data reports, general areal appraisals, and detailed aquifer investigations.

Complete citations for all the publications referenced in figures $9,10,11$, and 12 are listed by report series in table 41 (at back of report).

\section{Sources of Information Presented in Tables}

Sources of geologic and hydrologic information for the 37 quadrangles covering Rhode Island have been compiled based on information categories listed in table 3 . The 14 categories listed in table 3 cover the general subjects of geology, ground-water occurrence, ground-water movement, and ground-water quality. Technical terms used in these information categories are defined in the Glossary.

Sources of information for each of the 37 quadrangles covering Rhode Island are tabulated in tables 4-40 (at back of report). A headnote preceding table 4 lists abbreviations used in tables 4-40. Tables 4-40 are arranged alphabetically by quadrangle name (see table 1 for list). Each table lists the major categories of geologic and hydrologic information available for that quadrangle, provides references to the publications in which the information can be found, and indicates the format and scale of the information. If the information from a particular source does not cover the whole quadrangle, this is noted in the remarks. 


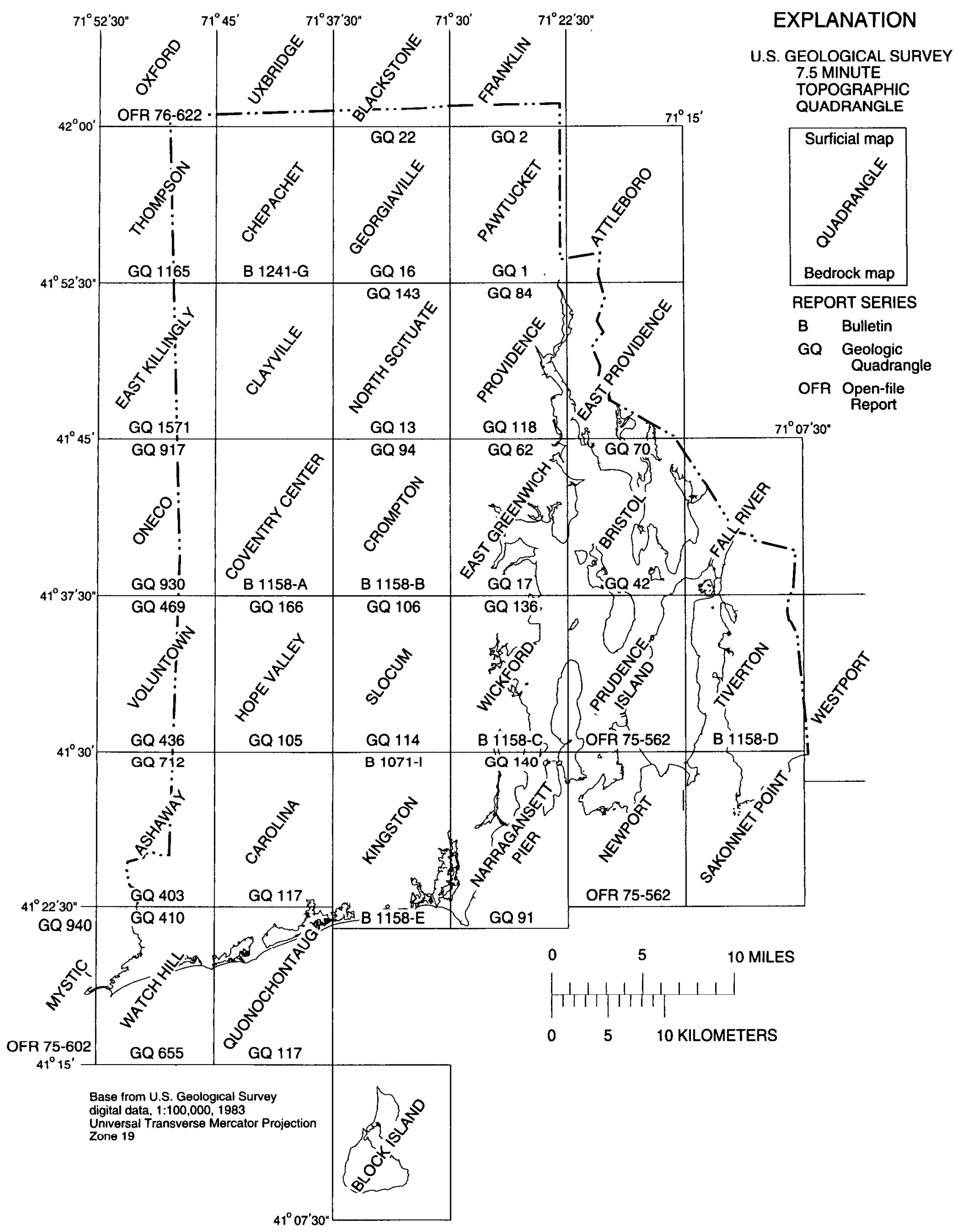

Figure 9. Avallabillty of surficlal and bedrock geologic maps by quadrangle in Rhode Island. Full citations for publications are listed by report series in table 41. All report series shown are U.S. Geological Survey publications. 


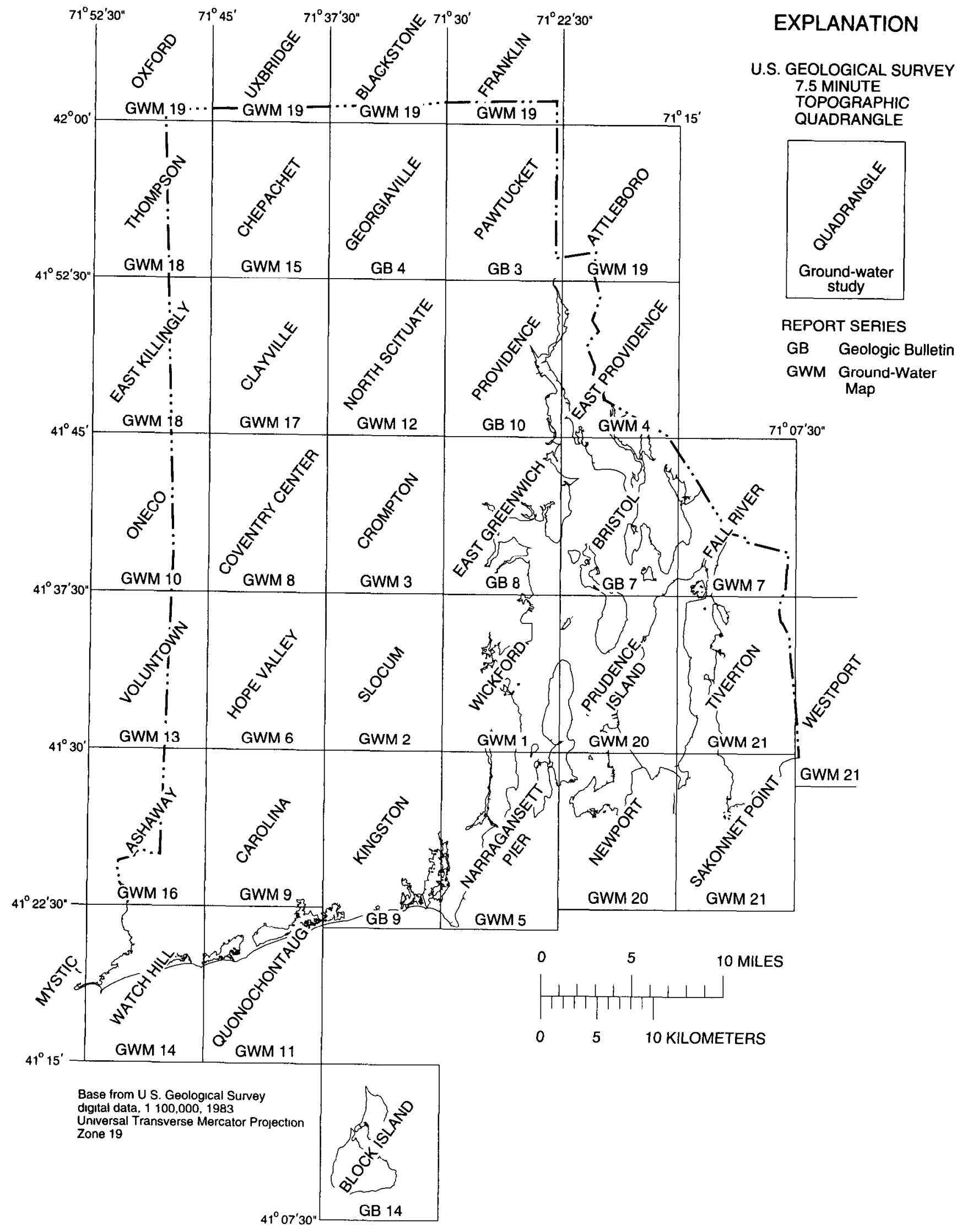

Figure 10. Availability of ground-water studies for quadrangles in Rhode Island. Full citations for publications are listed by report series in table 41. Both report series shown are published by the State of Rhode Island. 


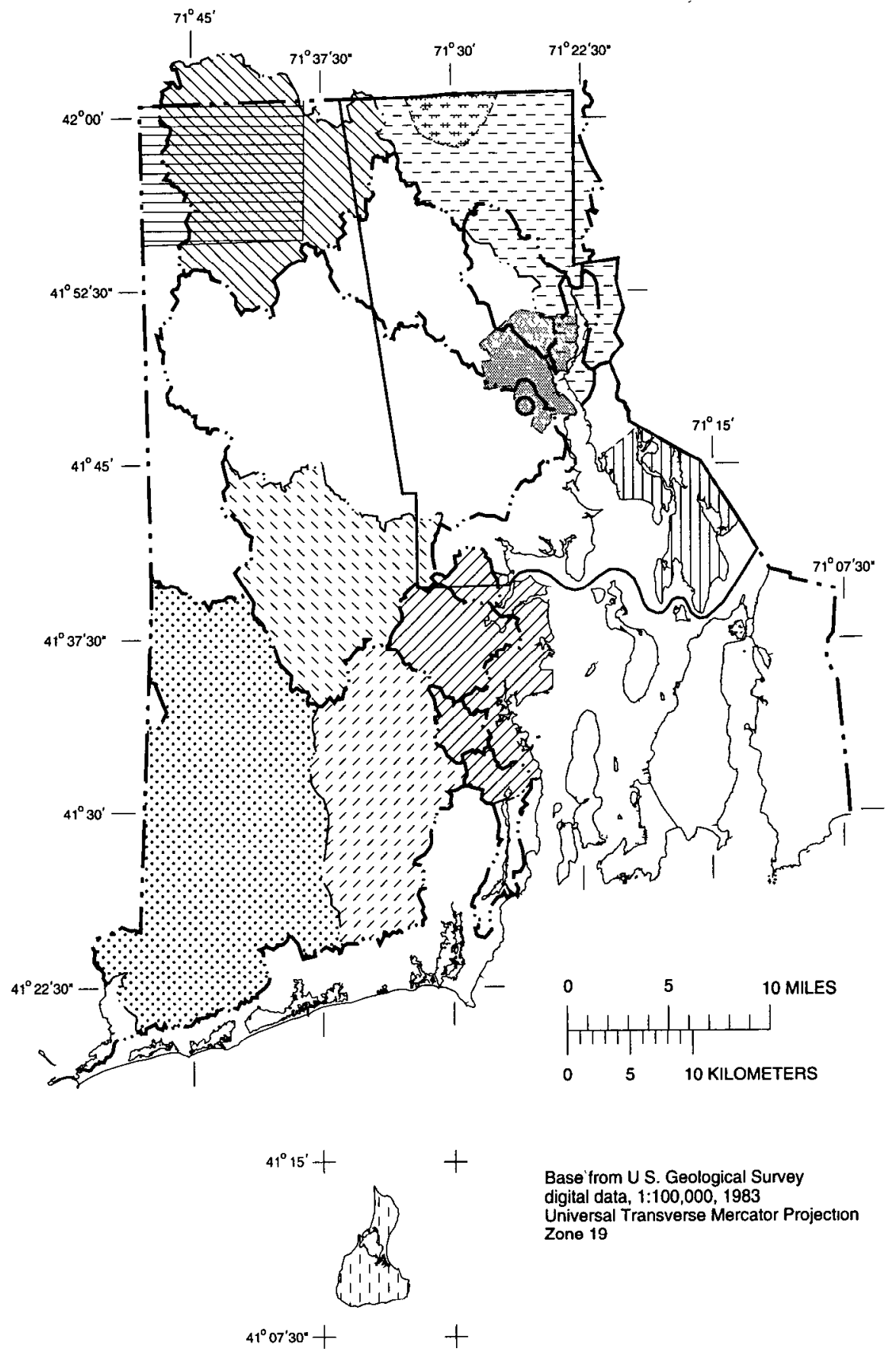

EXPLANATION

Study Areas and Reports

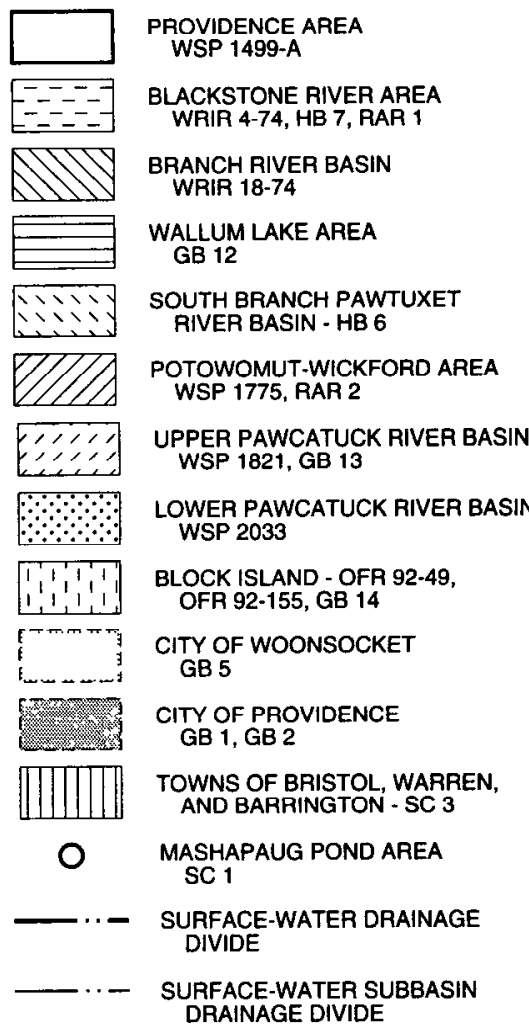

REPORT SERIES

$\begin{array}{ll}\text { GB } & \text { Geologic Bulletin } \\ \text { HB } & \text { Hydrologic Bulletin } \\ \text { OFR } & \text { Open-File Report } \\ \text { RAR } & \text { Recharge-Area Report } \\ \text { SC } & \text { Scientific Contribution } \\ \text { WRIR } & \begin{array}{l}\text { Water-Resources } \\ \text { Investigations Report }\end{array} \\ \text { WSP } & \text { Water-Supply Paper }\end{array}$

Figure 11. Availability of ground-water studies for drainage basins, subbasins, and special study areas in Rhode Island. Study-area boundaries are formed by surface-water drainage divides unless otherwise indicated. Full citations for publications are listed by report series in table 41. Report serles shown include U.S. Geological Survey and State of Rhode Island publications. Studies for subbasins of the Pawcatuck River basin are shown in figure 12. 


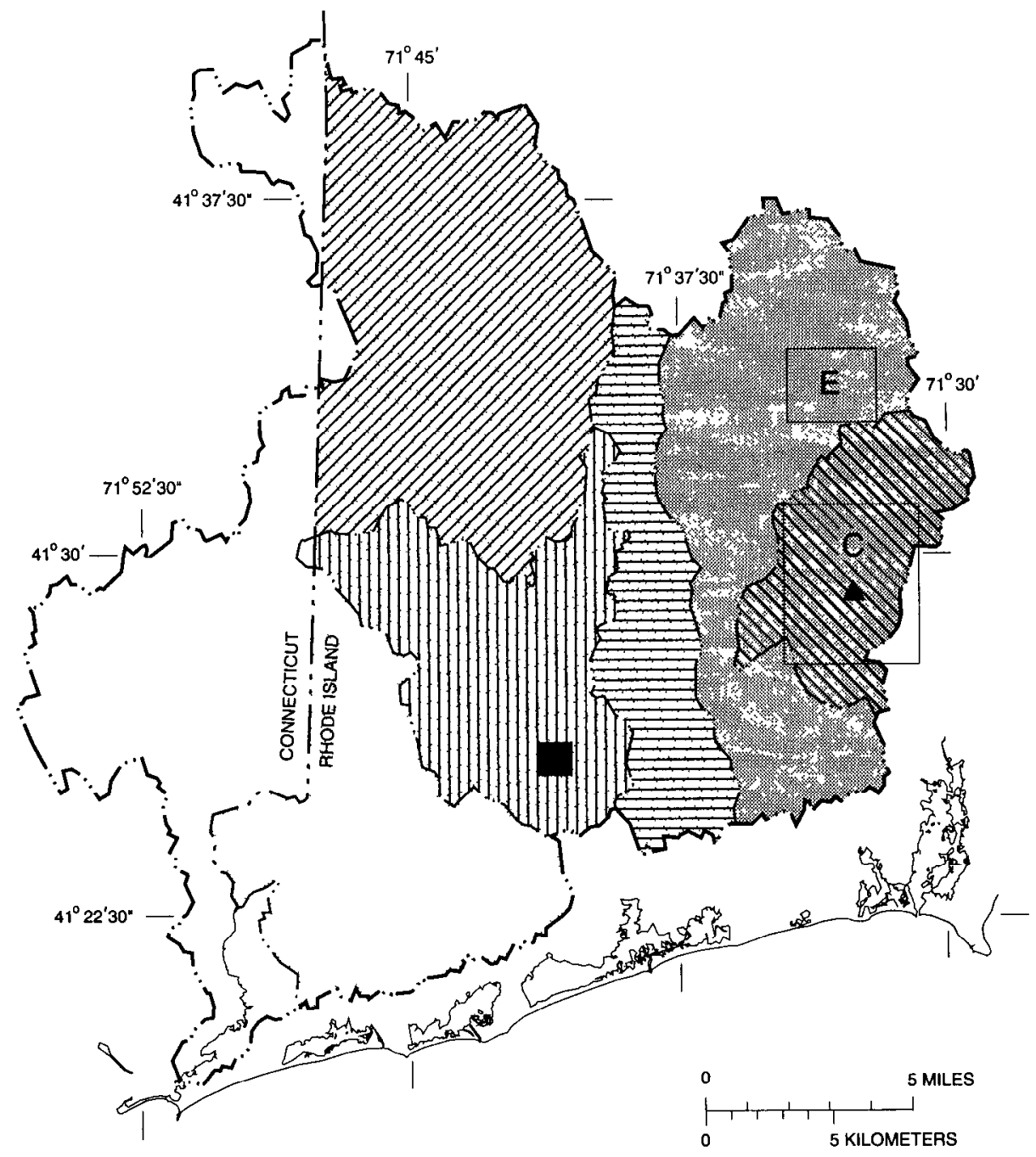

EXPLANATION

Study Areas and Reports

1.17) UPPER PAWCATUCK RIVER BASIN 1..2 WSP 1821, GB 13

LOWER PAWCATUCK RIVER BASIN

C CHIPUXET RIVER BASIN AREA

C WRIR 83-4231, WRIR 84-4254, WISR

NIIIV CHIPUXET RIVER BASIN

$E$ EXETER AREA

E
EXETER AREA
SC 2
BEAVER-PASQUISET RIVER B
WRIR 85-4190, WISR 3
UPPER WOOD RIVER BASIN
WRIR 92-4119, WISR 5
LOWER WOOD RIVER BASIN
WRIR 89-4031, WISR 4

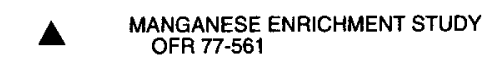

LOW-LEVEL RADIONUCLIDE STUDY WSP 2270, OFA 84-725

-... SURFACE-WATER DRAINAGE DIVIDE

$-\cdots-$ SURFACE-WATER SUBBASIN DRAINAGE DIVIDE

REPORT SERIES

$\begin{array}{ll}\text { GB } & \text { Geologic Bulletin } \\ \text { OFR } & \text { Open-File Report } \\ \text { RAR } & \text { Recharge-Area Report } \\ \text { WISA } & \begin{array}{l}\text { Water Information Series } \\ \text { Report }\end{array} \\ \text { WRIR } & \begin{array}{l}\text { Water-Resources } \\ \text { Investigations Report }\end{array} \\ \text { WSP } & \text { Water-Supply Paper } \\ \text { SC } & \text { Scientific Contribution }\end{array}$

Base from U S Geological Survey

digital data, $1100,000,1983$

Universal Transverse Mercator Projection

Zone 19

Figure 12. Availability of ground-water studies for subbasins and special study areas in the Pawcatuck River Basin. Study-area boundaries are formed by surface-water drainage divides unless otherwise indicated. Full citations for publications are listed by report series in table 41 . Report series shown include U.S. Geological Survey and State of Rhode Island publications. Note: Patterns for Upper Pawcatuck and Lower Pawcatuck River basins overlap with several subbasin patterns. 
Table 3. Types of geologic and hydrologic Information for which sources are summarized in tables $4-40$ for quadrangles in Rhode Island

\begin{tabular}{ll}
\hline \multicolumn{1}{c}{ Information category } \\
\hline Surficial geology \\
Bedrock geology \\
Subsurface materials \\
Altitude of bedrock surface \\
Water-table altitudes \\
Water-table contours \\
Saturated thickness \\
Hydraulic conductivity \\
Transmissivity \\
Drainage divides \\
Recharge areas \\
Ground-water reservoirs \\
Induced infiltration \\
Ground-water quality \\
\hline
\end{tabular}

Publications in tables 4-40 are referenced by a publication series abbreviation and number. Series abbreviations are explained in the headnote to tables 4-40. The series abbreviations refer to the report series listed in table 41 . Table 41 lists, by report series, full citations for publications prepared by the U.S. Geological Survey pertaining to the geology and hydrology of Rhode Island. Report series published by the U.S. Geological Survey are listed first, followed by report series published by several State agencies.

Publications are cited under an information category in tables 4-40 only if the information is directly available or can be quickly calculated by the reader. In many instances, data or interpretive material in a publication can be used by the reader, with more extensive effort, to make additional estimates or interpretations regarding the ground-water resource. Thus, even where an information category is not listed in a quadrangle table, it may be possible to derive information on this subject from the published literature.

A brief discussion of each information category (table 3) used in tables 4-40 is included here. Technical terms used in these information categories are defined in the Glossary.

Surficial Geology.-Information on surficial geology refers to the unconsolidated sediments that overlie bedrock in most of Rhode Island. Surticial geologic maps in the Geologic Quadrangle and Bulletin series typically describe in detail the deposits visible at the Earth's surface. Publications in other series may only show the general distribution of till and stratified drift.

Bedrock Geology.-Detailed information on the types of bedrock underlying different parts of the State can be found in the bedrock maps of the Geologic Quadrangle, Bulletin, and Open-File Report series. More gencralized maps showing major bedrock features are included in some publications.

Subsurface Materials. - Where unconsolidated deposits are moderately thick, surficial geologic maps may only describe the deposits closest to the Earth's surface. Well records, lithologic logs, geologic sections, and interpretive maps may provide information on subsurface materials not shown in surficial geologic maps, and in some cases information on bedrock as well. Publications vary considerably in the amount of detail provided on subsurface materials and in the format of the information.

Altitude of Bedrock Surface.-Maps in several publication series may show bedrock outcrops, bedrock altitudes at well locations, or contours providing an approximate description of the bedrock surface. Where tables of well records provide land-surface altitude and depth to bedrock, the bedrock altitude can be calculated. Conversely, where land-surface altitude and bedrock altitude are given, the depth to bedrock (that is, the thickness of unconsolidated material) can be determined. Bedrock altitudes are generally determined from wells and test borings. In some publications, the altitude of the bedrock surface has been determined from seismic refraction data.

Water-Table Altitudes.-Maps or tables of well records may show water-table altitudes at well locations. Where well records give land-surface altitude and depth to water, the water-table altitude can be calculated. Conversely, where land-surface altitude and water-table altitude are given, depth to water can be calculated. Water-table altitudes vary seasonally and from year to year. Individual publications provide information on the dates of water-level data collection. Some publications show extreme values (maximum and minimum water levels for the period of record) for selected wells. 
Water-Table Contours.-Maps may show contours providing an approximate description of the water-table surface. Where water-table contours are shown, actual water-table altitudes at selected wells may also be shown. Individual publications give information on dates of data collection, and may also reference data reports containing detailed information on water levels.

Saturated Thickness. - This term is usually used in reference to stratified-drift aquifers. Saturated thickness is usually calculated as the difference between the water-table altitude (the top of the aquifer) and the altitude of the bedrock surface (the bottom of the aquifer), where the till layer between the stratified drift and the bedrock is thin or absent. Maps may show lines of equal saturated thickness, an interpretation based on watertable altitude and bedrock-surface altitude. Saturated thickness can be calculated from well data on watertable altitude and bedrock altitude, or determined approximately from maps that present water-table contours and bedrock contours.

Hydraulic Conductivity.-Hydraulic conductivity values may be estimated from lithologic logs, computed from laboratory analyses of sediment samples, or computed from aquifer tests or specific capacity data. Individual publications give information on the data and methods used to determine aquifer hydraulic properties. Hydraulic conductivity is a property that varies with direction in an aquifer. The horizontal hydraulic conductivity in a stratified-drift aquifer is typically much greater than the vertical hydraulic conductivity. Publications may present information on horizontal or vertical hydraulic conductivity or both. Hydraulic conductivity values are usually presented in tables. Where lines of equal transmissivity and equal saturated thickness are available on maps, approximate values for hydraulic conductivity can be calculated.

Transmissivity.-Transmissivity values may be estimated from lithologic logs or computed from specific capacity data or from aquifer tests. Individual publications give information on the data and methods used to determine transmissivity. Data reports such as the Water Information Series Reports give detailed descriptions of aquifer test sites and extensive tabulated data. Interpretive reports such as some of those in the Water-Resources Investigations Reports or Water-Supply Paper series may summarize aquifer test data in tables and show lines of equal transmissivity on maps. Some older publications may use the term "transmissibility" for this aquifer property rather than transmissivity.

Drainage Divides.-Information on drainage divides in tables 4-40 refers to surface-water drainage divides unless otherwise noted in the remarks. A few publications contain information on groundwater drainage divides that do not coincide with surface-water drainage divides. In the till-covered bedrock uplands throughout much of Rhode Island, groundwater drainage divides coincide approximately with surface-water drainage divides.

Recharge Areas.-Most of Rhode Island is a recharge area, that is, an area in which water infiltrates the land surface, percolates downward, and reaches the zone of saturation. As used in tables 4-40, the term "recharge area" refers to a land area that contributes ground-water recharge to a specific location of interest, such as a well field or an entire aquifer. Recharge areas for aquifers or wells have only been delineated in a few areas of Rhode Island, and are shown on maps in a small number of reports. The absence of this information category in a quadrangle table means that recharge areas have not been delineated within the quadrangle; it does not mean that no recharge areas are present.

Ground-Water Reservoirs.-The term "groundwater reservoir" has had various meanings and definitions historically and among different water-resource agencies. The Rhode Island Water Resources Board has defined "ground-water reservoir" to mean a stratifieddrift deposit with transmissivity equal to or greater than 4,000 feet squared per day and saturated thickness equal to or greater than 40 fect (W.B. Allen, Rhode Island Water Resources Board, written commun., 1978). The Rhode Island Water Resources Board has identified 21 ground-water reservoirs (fig. 5) based on this definition, which is used widely by State water-resource agencies in Rhode Island. Historically, the U.S. Geological Survey in Rhode Island has used the term in a broader sense to indicate a stratified-drift aquifer with good potential for development. In a number of recent U.S. Geological Survey publications, the perimeter of the ground-water reservoir is defined primarily by the contact between till and stratified drift, rather than by the 40-foot saturated thickness contour in stratified drift. Thus the term as used in U.S. Geological Survey publications typically encompasses a larger area of aquifer than that defined by the Rhode Island Water 
Resources Board. Individual publications referenced in tables 4-40 use various definitions for ground-water reservoirs.

Aquifer-test information for sites in some groundwater reservoirs is tabulated in the Water Information Series Reports. Interpretive reports such as the WaterResources Investigations Reports and the Water-Supply Papers may include tabled estimates of potential well yields in ground-water reservoirs, based on aquifer tests, mathematical models, or computer simulation models. Most interpretive reports, rather than showing an agency-defined boundary for a ground-water reservoir, show the defining geologic and hydraulic characteristics--the contact between stratified drift and till, lines of equal saturated thickness, and lines of equal transmissivity. The Recharge-Area Report series shows the ground-water reservoir boundaries as defined by the Rhode Island Water Resources Board and modified by the Rhode Island Department of Environmental Management. The absence of this information category in a quadrangle table may mean either that there is no portion of an identified ground-water reservoir within the quadrangle, or that detailed information is not available for ground-water reservoirs within the quadrangle. However, publications covering the quadrangle may contain information that can be used to estimate, at least roughly, the ground-water development potential of an aquifer.

Induced Infiltration.-Estimates of streambed infiltration rates or estimates of the potential amount of infiltration that hypothetical wells may induce into an aquifer from nearby streams may be presented in tables or discussed in the text of some report series. Individual reports indicate the data and methods used to estimate induced infiltration.

Ground-Water Quality.-Most publications present ground-water quality data in tables. A few publications show selected ground-water-quality data in maps or hydrogeologic sections.
Sources of information on surface-water quality have not been compiled in tables 4-40. Information on surface-water quality may be pertinent to ground-water quality in areas where wells induce water into aquifers from nearby streams. Several report series listed in table 41 contain surface-water-quality data, in particular the Water-Data Reports, Water-Resources Investigations Reports, and Water-Supply Papers published by the U.S. Geological Survey, and the Water Information Series Reports published by the Rhode Island Water Resources Board.

The following example illustrates the use of tables 4-40. A previous example noted that surficial geologic maps are available for all the quadrangles covering the town of West Greenwich except for the Coventry Center quadrangle. Information for the Coventry Center quadrangle is summarized in table 12 . This table shows that, although a detailed surficial map is not available, four other reports show till and stratified-drift deposits for all or part of the quadrangle. Thus, some generalized information on surficial geology is available for the part of West Greenwich covered by the Coventry Center quadrangle. Table 12 lists several other sources of hydrogeologic information that may be useful in understanding the ground-water resources of the West Greenwich area.

Review of the information for quadrangles in tables 4-40 shows substantial variation in the availability of geologic and hydrologic information throughout the State. In general, the northern, northeastern, and southwestern parts of the State have been investigated more intensively than the central, western, and southeastern parts of the State, as shown in figures 11 and 12. Information is particularly abundant in parts of the Pawcatuck River Basin, as shown in tables for the Carolina, Hope Valley, and Kingston quadrangles (tables 9, 20, and 21). Comparison of these three tables with tables for Clayville, East Killingly, and Tiverton (tables 11, 15, and 35) shows that there are substantial variations in quantity and variety of data, and also in how recently different areas of the State have been investigated. 


\section{SELECTED REFERENCES}

Allen, W.B., 1953, The ground-water resources of Rhode Island: Rhode Island Development Council Geological Bulletin 6, 170 p., 1 pl.

Baldwin, H.L., and McGuinness, C.L., 1963, A primer on ground water: U.S. Geological Survey, 26 p.

Boothroyd, J.C., and Hermes, O.D., 1981, Guidebook to geological field studies in Rhode Island and adjacent areas: University of Rhode Island, 383 p.

Fenneman, N.M., 1938, Physiography of eastern United States: New York, McGraw-Hill, 714 p.

Flint, R.F., 1957, Glacial and Pleistocene geology: New York, John Wiley \& Sons, 553 p., 5 pl.

Freeze, R.A., and Cherry, J.A., 1979, Groundwater: Englewood Cliffs, N.J., Prentice-Hall, 604 p.

Handman, E.H., 1986, Delineating recharge areas for stratified-drift aquifers in Connecticut with geologic and topographic maps: U.S. Gcological Survey WaterResources Investigations Report 83-4230, 39 p.

Hansen, A.J., and Schiner, G.R., 1964, Ground-water resources of Block Island, Rhode Island: Rhode Island Water Resources Coordinating Board Geological Bulletin 14, 35 p., 1 pl.

Harrison, E.Z., and Dickinson, M.A., 1984, Protecting Connecticut's groundwater; a guide to groundwater protection for local officials: Connecticut Department of Environmental Protection, 37 p., 4 appendixes.

Heath, R.C., 1983, Basic ground-water hydrology: U.S. Geological Survey Water-Supply Paper 2220, 84 p.

1984, Ground-water regions of the United States: U.S. Geological Survey Water-Supply Paper 2242, 78 p.

Hem, J.D., 1985, Study and interpretation of the chemical characteristics of natural water ( $3 \mathrm{~d}$ ed.): U.S. Geological Survey Water-Supply Paper 2254, 263 p., 3 pl.

Hill, D.E., and Thomas, H.F., 1972, Use of natural resource data in land and water planning: Connecticut GeologySoil Task Force Report, Connecticut Agricultural Experiment Station Bulletin 733, 47 p.

Johnston, H.E., 1985, Rhode Island ground-water resources, in U.S. Geological Survey, National water summary 1984 hydrologic events, selected water-quality trends, and ground-water resources: U.S. Geological Survey Water-Supply Paper 2275, p. 373-378.
1986, Rhode Island surface-water resources, in U.S. Geological Survey, National water summary 1985hydrologic events and surface-water resources: U.S. Geological Survey Water-Supply Paper 2300, p. 407412.

1988, U.S. Geological Survey ground-water studies in Rhode Island: U.S. Geological Survey Open-File Report 88-139, 1 sheet.

Johnston, H.E., and Barlow, P.M., 1988, Rhode Island groundwater quality, in U.S. Geological Survey, National water summary 1986-hydrologic events and ground-water quality: U.S. Geological Survey Water-Supply Paper 2325, p. 443-448.

Lang, S.M., 1961, Appraisal of the ground-water reservoir areas in Rhode Island: Rhode Island Water Resources Coordinating Board Geological Bulletin 11, 38 p., 5 pl.

Langbein, W.B., and Iseri, K.T., 1960, Manual of hydrology, Part 1, General surface-water techniques-general introduction and hydrologic definitions: U.S. Geological Survey Water-Supply Paper 1541-A, 29 p.

Larson, G.J., and Stone, B.D., eds., 1982, Late Wisconsinan glaciation of New England: Dubuque, Iowa, Kendall/ Hunt Publishing Company, $242 \mathrm{p}$.

Leopold, L.B., Clarke, F. E., Hanshaw, B.B., and Balsley, J.R., 1971, A procedure for evaluating environmental impact: U.S. Geological Survey Circular 645, 13 p., 1 pl.

Levere, A.M., 1990, Connecticut natural resources information directory and list of publications for the Connecticut Geological and Natural History Survey, 1989-90: Connecticut Department of Environmental Protection, 39 p., 2 appendixes.

Lohman, S.W., and others, 1972, Definitions of selected ground-water terms-revisions and conceptual refinements: U.S. Geological Survey Water-Supply Paper 1988, $21 \mathrm{p}$.

Massachusetts Audubon Society, 1983, An introduction to groundwater and aquifers: Lincoln, Mass., Community Groundwater Protection Project, Groundwater Information Flyer 1, $11 \mathrm{p}$.

1985, Protecting and maintaining private wells: Lincoln, Mass., Community Groundwater Protection Project, Groundwater Information Flyer 6, 22 p.

1986a, Landfills and groundwater protection: Lincoln, Mass., Community Groundwater Protection Project, Groundwater Information Flyer 8, 19 p. 
Massachusetts Audubon Society, 1986b, Pesticides and groundwater protection: Lincoln, Mass., Community Groundwater Protection Project, Groundwater Information Flyer 7, 22 p.

1986c, Underground storage tanks and groundwater protection: Lincoln, Mass., Community Groundwater Protection Project, Groundwater Information Flyer 5, $15 \mathrm{p}$.

1987, Road salt and groundwater protection: Lincoln, Mass., Community Groundwater Protection Project, Groundwater Information Flyer 9, 18 p.

McGuinness, C.L., 1963, The role of ground water in the National water situation: U.S. Geological Survey WaterSupply Paper 1800, 1121 p., 4 pl.

McIntosh, W.L., Eister, M.F., and Sparks, D.M., 1982 , Geologic map index of Massachusetts, Rhode Island, and Connecticut: U.S. Geological Survey.

Meinzer, O.E., 1923, Outline of ground-water hydrology, with definitions: U.S. Geological Survey Water-Supply Paper 494, $71 \mathrm{p}$.

1942, Ground water, in Meinzer, O.E., ed., Hydrology: New York, Dover Publications, p. 385-477.

Morrissey, D.J., 1989, Estimation of the recharge area contributing water to a pumped well in a glacial-drift, river-valley aquifer: U.S. Geological Survey WaterSupply Paper 2338, 41 p.

National Oceanic and Atmospheric Administration, 19541983, Climatological data-New England: Asheville, N.C., National Climatic Data Center.

Office of Technology Assessment, 1984, Protecting the Nation's groundwater from contamination: U.S. Congress, Office of Technology Assessment, v. 1, Summary and findings, OTA-0-233, 244 p.

Quinn, A.W., 1971, Bedrock geology of Rhode Island: U.S. Geological Survey Bulletin 1295, 68 p., 1 pl.

Pessl, Fred, Jr., Langer, W.H., and Ryder, R.B., 1972, Geologic and hydrologic maps for land-use planning in the Connecticut Valley with examples from the folio of the Hartford North Quadrangle, Connecticut: U.S. Geological Survey Circular 674, 12 p.

Rhode Island Department of Environmental Management, 1988, The state of the State's waters-Rhode Island; a report to Congress (PL 92-500, 305b): Division of Water Resources, variously paged.
Sinnott, Allen, 1982, Summary appraisals of the Nation's ground-water resources--New England Region: U.S. Geological Survey Professional Papcr 813-T, 23 p.

Solley, W.B., Merk, C.F., and Pierce, R.R., 1988, Estimated use of water in the United States in 1985: U.S. Geological Survey Circular 1004, 82 p.

Solley, W.B., Pierce, R.R., and Perlman, H.A., 1993, Estimated use of water in the United States in 1990: U.S. Geological Survey Circular 1081, 76 p.

Todd, D.K., 1980, Groundwater hydrology (2d ed.): New York, John Wiley \& Sons, 535 p.

Trench, E.C.T., 1991, Ground-water resources of Rhode Island: U.S. Geological Survey Open-File Report 91$199,169 \mathrm{p}$.

Trench, E.C.T., and Morrissey, D.J., 1985, Classification and delineation of recharge areas to the Blackstone and lower Blackstone-Moshassuck ground-water reservoirs in northeastern Rhode Island: Rhode Island Department of Environmental Management and Rhode Island Department of Administration, Office of State Planning, Recharge Area Report 1, 21 p., 1 pl.

U.S. Department of the Interior, 1987, List of U.S. Geological Survey geologic and water-supply reports and maps for Massachusetts, Rhode Island, and Connecticut: U.S. Government Printing Office, 98 p.

U.S. Environmental Protection Agency, 1984, Ground-water protection strategy: Office of Ground-Water Protection, $56 \mathrm{p}$. plus appendixes.

U.S. Geological Survey, 1977, Water-resources investigations in Rhode Island, 1977, 7 p.

1985a, Massachusetts, Rhode Island, and Connecticut; index to topographic and other map coverage, $23 \mathrm{p}$.

1985b, National water summary 1984-hydrologic events, selected water quality trends, and ground-water resources: U.S. Geological Survey Water-Supply Paper 2275,467 p.

1986, Goals of the U.S. Geological Survey: U.S. Geological Survey Circular 1010, 17 p.

1987, Massachusetts, Rhode Island, and Connecticut; catalog of topographic and other published maps, $19 \mathrm{p}$.

Wiltshire, D.A., Lyford, F.P., and Cohen, A.J., 1986, Bibliography on ground water in glacial-aquifer systems in the northeastern United States: U.S. Geological Survey Circular 972, 26 p. 


\section{GLOSSARY}

Aquifer: A geologic formation, group of formations, or part of a formation that contains sufficient saturated permeable material to yield significant quantities of water to wells and springs.

Aquifer test: A test to determine the water-yielding capacity of an aquifer. The test involves withdrawing a measured quantity of water from a well and measuring the resulting changes in water level in observation wells surrounding the pumped well. Potential yield of the well is estimated by analysis of the distance, time, and drawdown data.

Bacteria: Microscopic one-celled organisms, often aggregated into colonies. Some bacteria perform an essential role in nature in the recycling of materials, such as by decomposing organic matter into a form available for reuse by plants; others cause diseasc. See also Coliform bacteria.

Bedrock: Solid rock, commonly called "ledge" in Rhode Island, which forms the Earth's crust. It is locally exposed at the surface but more commonly is buried beneath a few inches to more than 300 feet of unconsolidated deposits.

Coliform bacteria: A particular group of bacteria, some of which inhabit the intestinal tracts of vertebrates. Although generally considered to be nonpathogenic, their presence in a water sample is regarded as evidence of possible pollution by sewage.

Color unit: A standard of color in water measured by the platinum-cobalt method. The color produced by 1 milligram per liter of platinum in water equals one color unit.

Computer simulation model: A computer program to solve a sct of cquations which simulate a given system. In the studies tabulated for this report, the equations simulate the ground-water-flow system.

Concentration: The amount of a solute, such as a mineral, dissolved in a specitied amount of a solvent, such as water.

Cone of depression: A depression produced in the water table or other potentiometric surface by the withdrawal of water from an aquifer. It is shaped like an inverted cone with its apex at the pumped well.

Confined aquifer: An aquifer bounded above and below by impermeable beds or by beds of distinctly lower permeability than that of the aquifer itself. Also called an artesian aquifer. See also Unconfined aquifer.

Confined ground water: Water in an aquifer that is bounded by beds of low or negligible permeability (confining beds). The ground water is under pressure that is significantly greater than that of the atmosphere.
Contact: A plane or irregular interface between two types or ages of rock or sediment. Also refers to the interface between two fluids, such as gasoline and water.

Contamination: The degradation of water quality as a result of human activity.

Contour line: A line on a map connecting points of equal value. A water-table contour line connects points of equal water-table altitude.

Crystalline bedrock: A general term including several igneous and metamorphic rocks. The most common types in Rhode Island are granite, gneiss, and schist.

Discharge: In hydraulics, the rate of flow; a volume of fluid passing a point per unit time, commonly expressed as cubic feet per second, million gallons per day, or gallons per minute.

Dissolved solids: The residue from a clear sample of water after evaporation and drying for one hour at $180^{\circ}$ Celsius. Dissolved solids consist primarily of dissolved mineral constituents, but may also contain organic matter and water of crystallization.

Drainage area: The land area, as measured on a map, that contributes water to a particular stream channel, lake, reservoir, or other body of water.

Drainage basin: A part of the surface of the Earth that is occupied by a drainage system, consisting of a stream or body of impounded surface water and all its tributary streams and bodies of surface water. Also referred to as river basin or watershed.

Drainage divide: The boundary between one drainage basin and another. The rim of a drainage basin. Unless otherwise specified, usually refers to a surface-water drainage divide.

Drawdown: The lowering of the ground-water level or potentiometric surface by pumping. It is equal to the difference between the static (nonpumping) level and the pumping level.

Formation: A part of the Earth's crust that is more or less distinct from other parts, either because of its origin, its mineral composition and arrangement, or its structure.

Fracture: A structural break or opening in bedrock along which water is able to move. A crack, joint, or fault.

Freshwater: Water that contains less than 1,000 milligrams per liter of dissolved solids. Generally, more than 500 milligrams per liter of dissolved solids is undesirable for drinking and many industrial uses.

Geologic section: A diagram drawn to scale representing successive rock units and geologic structures of the Earth's crust, as they would appear if cut through by an intersecting plane. Geologic sections referred to in this report are vertical sections. 
Geophysical log: A continuous record, obtained during drilling a well, of a geophysical characteristic of the rock units or well fluids penetrated, such as electrical properties, radiation, or temperature.

Glacier: A large mass of ice, formed on land by the compaction and recrystallization of snow, which moves slowly by creep downslope or outward in all directions because of the stress of its own weight, and which survives from year to year. Included are small mountain glaciers as well as ice sheets continental in size and ice shelves that float on the ocean but are fed in part by ice formed on land.

Gravel: Unconsolidated rock debris composed principally of particles larger than 0.08 inch in diameter.

Gravel-packed well: A type of well, commonly used for public-supply wells in stratified drift, in which gravel is placed in the space around the well screen to increase the effective diameter of the well and to prevent fine-grained sediments from entering the well.

Ground water: Water in the saturated zone.

Ground-water discharge: The release of water from the saturated zone by (1) natural processes such as discharge to streams and springs, or evaporation and transpiration from the saturated zone, and (2) withdrawal from wells.

Ground-water drainage divide: A ridge or hill in the irregular surface of the saturated zone. The water table slopes downward in a direction away from the divide on both sides of the divide. A ground-water drainage divide is analogous to, but not always coincident with, a topographic drainage divide on the land surface between two surface-water drainage basins.

Ground-water recharge: (1) The amount of water that is added to the saturated zone. (2) The process by which water is added to the saturated zone.

Ground-water reservoir: Generally, a stratified-drift aquifer with good potential for yielding large amounts of water. As defined by the Rhode Island Water Resources Board, a ground-water reservoir is an area underlain by stratified drift with transmissivity equal to or greater than 4,000 feet squared per day and a saturated thickness equal to or greater than 40 feet. In reports of the U.S. Geological Survey, ground-water reservoirs are generally bounded by the contact between stratified drift and till rather than by the 40 -foot saturated thickness contour.

Hardness (water): A property of water causing formation of an insoluble residue when the water is used with soap, and forming a scale in containers in which water has been allowed to evaporate. It is caused primarily by the presence of ions of calcium and magnesium. Generally expressed as milligrams per liter $(\mathrm{mg} / \mathrm{L})$ as calcium carbonate $\left(\mathrm{CaCO}_{3}\right)$. A general hardness scale is: soft, $0-60 \mathrm{mg} / \mathrm{L}$; moderately hard, $61-120 \mathrm{mg} / \mathrm{L}$; hard, $121-180 \mathrm{mg} / \mathrm{L}$; very hard, more than $180 \mathrm{mg} / \mathrm{L}$ (U.S. Geological Survey, 1985b, p. 461).

Hazardous waste: Any substance that is toxic, or otherwise is a threat to life, that is discharged through human activity to the land, water, or atmosphere. Synthetic organic chemicals and trace metals are some of the more significant contaminants associated with hazardous waste.

Head (static): The height above a standard datum of the surface of a column of water that can be supported by the static pressure at a given point. The static head, which is the sum of the elevation head and the pressure head, is the height to which water will rise in a tightly cased well. Ground water is in motion, and head is a measure of the mechanical energy of the ground water at a given point in space and time.

Hydraulic conductivity: The volume of water at the existing kinematic viscosity that will move in unit time under a unit hydraulic gradient through a unit area measured at right angles to the direction of flow in an isotropic porous medium. More simply, hydraulic conductivity is a measure of the ease with which a fluid will pass through a porous earth material, such as stratified drift or till. Hydraulic conductivity is determined by the sizc and shape of the pore spaces in the material, and their degree of interconnection, as well as by the viscosity of the fluid. In this report, hydraulic conductivity is given in units of feet per day, which is a simplified form of cubic feet of water per day per square foot cross-section of earth material. Many of the older publications referenced in this report show hydraulic conductivity values in gallons per day per square foot; this unit of measure is no longer used.

Hydraulic gradient: In an aquifer, the change in static head per unit of distance in a given direction. If not specified, the direction is generally understood to be that of the maximum rate of decrease in head.

Hydrocarbons: A large and diverse group of natural and synthetic organic compounds, composed primarily of hydrogen and carbon, with varying amounts of other elements.

Hydrogeology: The science that deals with subsurface waters and with related geologic aspects of surface waters.

Hydrology: The science that relates to the water of the Earth.

Induced infiltration: The process by which water in a stream or lake moves into an aquifer when a hydraulic gradient from the surface-water body toward the aquifer has been established because of the withdrawal of water from a pumped well or wells.

Induced recharge: The amount of water entering an aquifer from an adjacent surface-water body by the process of induced infiltration. 
Infiltration: The passage of a gas or liquid into or through soil or rock by way of pores or small openings in the earth material.

Inorganic constituents: Chemical compounds that do not contain carbon as the principal element (excepting carbonates, cyanides, and cyanates). Major inorganic constituents in Rhode Island ground water include: silica, iron, manganese, calcium, magnesium, sodium, potassium, hydrogen ion $(\mathrm{pH})$, carbonate, bicarbonate, sulfate, chloride, fluoride, nitrate, dissolved oxygen. Chemical properties that are closely related to the major inorganic constituents include dissolved solids, hardness, and alkalinity.

Ion: An atom or group of atoms that carries an electric charge as a result of having lost or gained electrons.

Isotropic: Having properties that are uniform in all directions. Earth materials are seldom isotropic.

Kinematic: Pertaining to the motions of materials.

Lacustrine: Pertaining to, produced by, or formed in a lake or lakes, such as lacustrine sediments formed on a lake bottom. Many fine-grained lacustrine sediments in Rhode Island were formed in glacial lakes.

Lithologic log: A log, or continuous record, depicting the sequence of lithologic characteristics of the soil, sediments, and rocks penetrated in drilling a well. The descriptive information is related to the depth of origin of the materials. Lithologic logs referred to in this report may be narrative in format or may be graphic and plotted to scale.

Lithology: The physical character of a sediment or rock, including such characteristics as color, mineralogic composition, and grain size.

Low-level radioactive waste: Nuclear wastes resulting from a variety of activities, including university research programs, medical treatment, and electrical power generation. The radioactivity of low-level wastes is considerably less than that of high-level nuclear wastes associated with nuclear fuel.

Mathematical model: A model commonly used to determine aquifer characteristics from aquifer tests and to predict drawdowns that will occur in the vicinity of a pumped well. The use of the model requires simplification of the aquifer geometry and hydraulic properties. Some typical simplifying assumptions are that aquifer properties are homogeneous and isotropic and that the aquifer is confined (Morrissey, 1989, p. 9, 11). Mathematical models, sometimes referred to as analytical models, have been used to estimate aquifer yields in many of the older interpretive studies referenced in this report.

Methylene blue active substance (MBAS): A measure of apparent detergents, as indicated by the formation of a blue color when methylene blue dye reacts with synthetic detergent compounds.
Micrograms per liter $(\mu \mathrm{g} / \mathrm{L})$ : A unit for expressing the concentration of chemical constituents in solution. Micrograms per liter represents the weight of solute per unit volume of water; 1,000 micrograms equal 1 milligram. One microgram equals $1 \times 10^{-6}$ gram. Micrograms per liter and parts per billion (ppb) are approximately equivalent, with $1 \mu \mathrm{g} / \mathrm{L}$ equal to $1 \mathrm{ppb}$. However, micrograms per liter is the standard unit for reporting dissolved constituents.

Milligrams per liter (mg/L): A unit for expressing the concentration of chemical constituents in solution. Milligrams per liter represents the weight of solute per unit volume of water; 1 milligram equals 1,000 micrograms. One milligram equals $1 \times 10^{-3}$ gram. At the low concentrations of dissolved solids typically found in fresh ground water, milligrams per liter and parts per million (ppm) are approximately equivalent, with $1 \mathrm{mg} / \mathrm{L}$ equal to $1 \mathrm{ppm}$. However, milligrams per liter is the standard unit for reporting dissolved constituents.

Nutrients: Compounds of nitrogen, phosphorous, and other elements essential for plant growth.

Organochlorine compounds: A group of synthetic organic compounds that are toxic and persistent in the environment. They include aldrin, chlordane, DDT, lindane, and toxaphene.

Outcrop: A place where a geologic formation is visible at the Earth's surface.

Overland flow: The flow of rainwater or snowmelt over the land surface toward stream channels. After it enters a stream, it becomes runoff.

Perched ground water: A thin, local, unconfined saturated zone separated from an underlying main body of ground water by an unsaturated zone. The perched ground water is supported by material of low permeability that prevents downward percolation of water.

Percolation: Streamline flow of water, usually downward, by the force of gravity or under hydrostatic pressure, through small openings within a porous material such as rock or sediment.

Permeability: A qualitative term used to describe the ease with which water will pass through a porous earth material. See also Hydraulic conductivity, the quantitative term used by the U.S. Geological Survey to define this property.

Pesticides: Chemical compounds used to control undesirable plants and animals. The major categories of pesticides include insecticides, miticides, fungicides, herbicides, and rodenticides.

pH: The hydrogen-ion activity of a solution. A pH value is a number, on a scale of 1 to 14 , that is equal to the negative logarithm of the hydrogen-ion concentration. This value is used by chemists to measure the reactive 
characteristics of water. A pH value of 7 is neutral. Values less than 7 indicate acidic solutions that are corrosive and tend to dissolve metals and other substances. Values greater than 7 indicate alkaline or basic solutions that tend to form scale when heated. The difference between each unit on the scale represents one order of magnitude. For example, a pH of 5 is 10 times more acidic than a $\mathrm{pH}$ of 6 , and a $\mathrm{pH}$ of 5 is 100 times more acidic than a pH of 7 .

Physical properties: Characteristics of water that describe the nature of the water as a whole, as contrasted to chemical characteristics that describe specific constitucnts dissolved within the water. Physical properties of ground water include: temperature, color, taste, odor, turbidity, and specific electrical conductance.

Physiographic province: A region in which all parts have a similar geologic structure and climate, and in which all parts have had a similar development of the present landforms. A region where the pattern of surface features or landforms differs substantially from that of adjacent regions.

Physiography: A description of the surface features of the Earth.

Pollution: The presence in or addition to water of any substance that is or could become injurious to the public health, safety, or welfare; or that is or could become injurious to domestic, commercial, industrial, agricultural, or other uses being made of the water.

Potentiometric surface: A surface that represents the total head in an aquifer, that is, the level to which water will rise in tightly cased wells that penetrate the aquifer. The water table is a particular potentiometric surface.

Precipitation: (1) The discharge of water from the atmosphere in the forms of rain, sleet, snow, or hail; the opposite process is evaporation. (2) The process by which ions dissolved in a solution join together to form solid particles that settle out of the solution by gravity or adhere to nearby solid surfaces; the opposite process is solution, or the process of becoming dissolved.

Radionuclide: A species of atom that emits alpha, beta, or gamma rays for a measurable length of time.

Recharge: (1) Water that infiltrates to and supplies the saturated zone; recharge may be natural or artificial depending upon the source of the water. (2) The process that allows water to infiltrate to an aquifer.

Recharge area: As used in this report, a land area that contributes ground-water recharge to a location of interest, such as a well field or an entire aquifer. More generally, an area in which infiltrating water reaches the zone of saturation.

Saltwater: Water containing about 35,000 milligrams per liter of dissolved solids, including about 19,000 milligrams per liter of chloride $(\mathrm{Cl})$.
Saturated thickness: The thickness of an aquifer below the water table.

Saturated zone: The subsurface zone in which all open spaces are filled with water. The water table is the upper limit of this zone. Below the water table, water in the saturated zone is under pressure greater than that of the atmosphere.

Screened interval: The intake section of a well through which water is obtained from an unconsolidated aquifer, such as stratified drift. Ground water enters the well only along the screened interval; the rest of the well is cased to prevent entry of water.

Seismic refraction: A geophysical method of determining the depth to the water table or depth to a major change in earth material, such as the bedrock surface. A seismograph is used to determine the time it takes sound energy created by a small explosion to reach a series of sensors. Because sound travels at different velocities in different rock materials and is refracted (bent) at the boundary between these materials, it is possible to determine depths to different types of material or to the water table.

Seismic survey: The use of seismic refraction techniques in a study area to determine depth to the water table or depth to different types of earth material.

Specific capacity (of a well): The rate of discharge of water from a well divided by the drawdown of water level within the well, commonly expressed in gallons per minute per foot.

Specific conductance (of water): A measure of the ability of water to conduct an electric current, expressed in microsiemens per centimeter at 25 degrees Celsius. It is related to the concentration of dissolved solids, for which it serves as an approximate, indirect measure.

Stratified drift: Predominantly sorted sediments laid down in layers, by or in meltwater from a glacier. Includes gravel, sand, silt, or clay deposited in layers of similar grain size. The term "drift" is a historical remnant from the early 19 th century, when scientists believed that glacial materials had been deposited when debris-filled icebergs melted as they drifted across prehistoric oceans (Flint, 1957, p. 4).

Stream-aquifer system: Consists of a stream that is hydraulically connected to the aquifer across which it flows. Ground water generally discharges from the aquifer to the stream. Surface water may infiltrate the aquifer naturally under some conditions, or may be induced into the aquifer where ground water is withdrawn from wells near the stream.

Subsurface materials: Unconsolidated and consolidated rock materials lying beneath the Earth's surface.

Surficial sediments (deposits): Unconsolidated deposits lying on top of bedrock. 
Till: Predominantly unsorted, unstratified sediments deposited directly by a glacier and composed of boulders, gravel, sand, silt, and clay mixed in various proportions. Sometimes called unsorted drift. Colloquially, it is sometimes referred to as "hardpan."

Trace constituent: A substance that always or nearly always occurs in concentrations of less than 1.0 milligram per liter in natural water (Hem, 1985, p. 129).

Transmissivity: The rate at which water of the prevailing kinematic viscosity is transmitted through a unit width of the aquifer under a unit hydraulic gradient. More simply, transmissivity is a measure of the ability of an aquifer to transmit water. An aquifer's transmissivity is equal to its average horizontal hydraulic conductivity multiplied by its saturated thickness. Reported in units of feet squared per day, which is a simplified form of cubic feet of water per day per vertical prism of aquifer 1 foot wide. Many of the older publications referenced in this report show transmissivity values in gallons per day per foot; this unit of measure is no longer used. Older publications may also use the term "transmissibility" rather than "transmissivity."

Transpiration: The process whereby plants release water vapor to the atmosphere.

Unconfined aquifer: An aquifer in which the upper surface of the saturated zone, the watcr table, is at atmospheric pressure and is free to rise and fall. Also called a water-table aquifer.

Unconsolidated: A term used to describe earth materials in which the particles are loose, not firmly cemented or interlocked. For example, sand is unconsolidated and sandstone is consolidated.

Unsaturated zone: The subsurface zone between the land surface and the water table, containing air, gases, and variable amounts of water.
Viscosity: The property of a fluid that allows the fluid to resist motion and deformation under an applied force. The greater the viscosity of a fluid, the more slowly it flows. Viscosity in liquids is caused by the cohesiveness of the molecules, and is affected by temperature and pressure.

Volatile organic compounds (VOC's): Synthetic organic compounds that include hydrocarbon or halogenated hydrocarbon molecules. Halogenated hydrocarbons include the element chlorine or related elements. Many VOC's are industrial solvents and degreasers.

Water table: The upper surface of the saturated zone in an unconfined aquifer. It is defined by the levels at which water stands in wells that penetrate just deep enough to contain standing water. In wells that penetrate to greater depths, the water level will stand above the water table if an upward component of ground-water flow exists, or below the water table if a downward component of ground-water flow exists.

Water year: A continuous, 12-month period, selected to present data relative to hydrologic or meteorologic phenomena, during which a complete annual hydrologic cycle normally occurs. The water year used by the U.S. Geological Survey is October 1 through September 30. For example, October 1, 1984 through September 30, 1985 is the 1985 water year.

Watershed: (1) Drainage basin; (2) the divide separating one drainage basin from another. The first meaning is the more current usage, whereas the second meaning was common in the past. The terms "drainage basin" and "drainage divide" are preferred, because the meaning of the term "watershed" may be ambiguous.

Well screen: The intake section of a well, specially designed for obtaining water from unconsolidated materials, such as sand. The screen allows water to flow freely into the well and prevents sand from entering with the water.

Yield (of an aquifer): The amount of water that can be withdrawn continuously from an aquifer. 
TABLES 4-41 
Tables 4-40. Geologic and hydrologic information for Rhode Island quadrangles

Many publications have multiple maps or plates, which may be at different scales. Consequently, more than one scale may be shown for the same publication in tables $4-40$. The following abbreviations refer to publication series. Complete citations for these publications are listed by series in table 41 .

Published by the U.S. Geological Survey:

Other abbreviations:

\section{B Bulletin \\ GQ Geologic Quadrangle \\ OFR Open-File Report \\ PP Professional Paper \\ WRIR Water-Resources Investigations Report \\ WSP Water-Supply Paper}

Published by the State of Rhode Island:
GB Geologic Bulletin
GWM Ground-Water Map
HB Hydrologic Bulletin
RAR Recharge Area Report
SC Scientific Contribution
WISR Water Information Series Report

$\begin{array}{ll}\mathrm{NA} & \text { not applicable } \\ \mathrm{U} & \text { unpublished } \\ > & \text { greater than } \\ \geq & \text { greater than or equal to } \\ < & \text { less than } \\ \mathrm{d} & \text { day } \\ \mathrm{cm} / \mathrm{s} & \text { centimeter per second } \\ \mathrm{ft} & \text { foot or feet } \\ \mathrm{ft} / \mathrm{d} & \text { foot per day } \\ \mathrm{ft} / / \mathrm{d} & \text { foot squared per day } \\ \mathrm{gal} / \mathrm{d} & \text { gallon per day } \\ \mathrm{gal} / \mathrm{d} / \mathrm{ft}^{2} & \text { gallon per day per foot } \\ \mathrm{gal} / \mathrm{d} / \mathrm{ft}^{2} & \text { gallon per day per square foot } \\ \mathrm{Mgal} / \mathrm{d} & \text { million gallons per day } \\ \mathrm{mg} / \mathrm{L} & \text { milligram per liter } \\ \mu \mathrm{g} / \mathrm{L} & \text { microgram per liter } \\ & \end{array}$


Table 4. Geologic and hydrologic information for the Ashaway Quadrangle

\begin{tabular}{|c|c|c|c|c|}
\hline Information & Date & Publication & Scale & Remarks \\
\hline \multirow[t]{2}{*}{ Surficial geology ............................... } & 1961 & GWM 16 & $1: 24,000$ & Till and stratified-drift deposits. \\
\hline & 1968 & GQ 712 & $1: 24,000$ & $\begin{array}{l}\text { Detailed surficial map. Geology mapped in } 1961,1963 \text {, } \\
\text { and } 1965 .\end{array}$ \\
\hline \multirow[t]{2}{*}{ 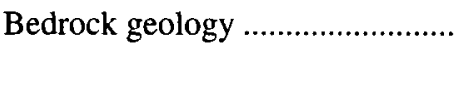 } & 1965 & GQ 403 & $1: 24,000$ & Detailed bedrock map. Geology mapped 1958-61. \\
\hline & 1971 & В 1295 & $1: 125,000$ & Bedrock geologic map of Rhode Island. \\
\hline \multirow[t]{3}{*}{ 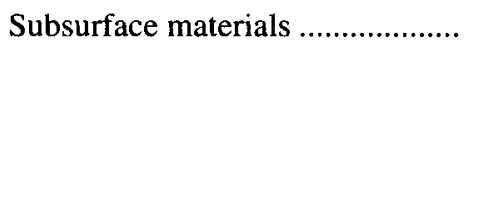 } & 1953 & GB 6 & $1: 122,000$ & $\begin{array}{l}\text { Records of wells and test borings show principal aquifer. } \\
\text { Not on topographic base. }\end{array}$ \\
\hline & 1960 & HB 3 & $1: 148,000$ & Lithologic $\log$ for 1 well. \\
\hline & 1961 & GB 11 & $1: 61,400$ & $\begin{array}{l}\text { Shows stratified-drift deposits } 0-50 \mathrm{ft} \text { thick. For Rhode } \\
\text { Island part of quadrangle. Not on topographic base. }\end{array}$ \\
\hline \multirow[t]{3}{*}{ Altitude of bedrock surface ............ } & 1953 & GB 6 & $1: 122,000$ & $\begin{array}{l}\text { Records of wells and test borings give land-surface alti- } \\
\text { tude and depth to bedrock. Not on topographic base. }\end{array}$ \\
\hline & 1961 & GWM 16 & $1: 24,000$ & $\begin{array}{l}\text { Approximate bedrock contours in stratified drift, } 50 \mathrm{ft} \\
\text { interval. Altitude of bedrock surface shown at well } \\
\text { locations. Bedrock outcrops shown. }\end{array}$ \\
\hline & 1974 & WSP 2033 & $1: 48,000$ & $\begin{array}{l}\text { Approximate bedrock contours, } 50 \mathrm{ft} \text { interval. For Lower } \\
\text { Pawcatuck Basin. }\end{array}$ \\
\hline \multirow[t]{2}{*}{ 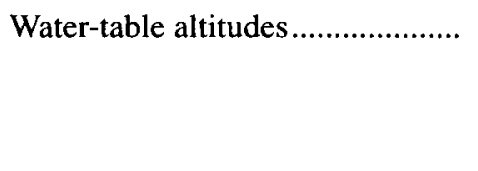 } & 1953 & GB 6 & $1: 122,000$ & $\begin{array}{l}\text { Well records give land-surface altitude and depth to } \\
\text { water. Not on topographic base. }\end{array}$ \\
\hline & 1961 & GWM 16 & $1: 24,000$ & $\begin{array}{l}\text { Water-table altitudes shown at well locations. Data on } \\
\text { wells collected chiefly in } 1961 .\end{array}$ \\
\hline \multirow[t]{2}{*}{ 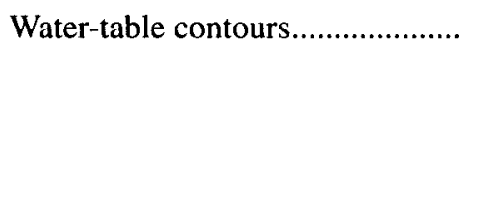 } & 1961 & GWM 16 & $1: 24,000$ & $\begin{array}{l}\text { Approximate water-table contours in stratified drift, } 10 \\
\text { and } 20 \mathrm{ft} \text { intervals. Data on wells collected chiefly in } \\
1961 .\end{array}$ \\
\hline & 1974 & WSP 2033 & $1: 48,000$ & $\begin{array}{l}\text { Water-table contours in stratified drift, } 10 \mathrm{ft} \text { interval. For } \\
\text { Lower Pawcatuck Basin. }\end{array}$ \\
\hline Saturated thickness............................. & 1974 & WSP 2033 & $1: 48,000$ & $\begin{array}{l}\text { Lines of equal saturated thickness, } 20 \mathrm{ft} \text { interval. For } \\
\text { Lower Pawcatuck Basin. }\end{array}$ \\
\hline 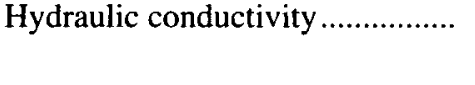 & 1960 & HB 3 & $1: 148,000$ & $\begin{array}{l}\text { Computed from aquifer test on } 1 \text { well. Shown in } \\
\mathrm{gal} / \mathrm{d} / \mathrm{ft}^{2} \text {. }\end{array}$ \\
\hline \multirow[t]{2}{*}{ Transmissivity .................................. } & 1960 & HB 3 & $1: 148,000$ & $\begin{array}{l}\text { Computed from aquifer test on } 1 \text { well. Shown in } \\
\mathrm{gal} / \mathrm{d} / \mathrm{ft} \text {. }\end{array}$ \\
\hline & 1974 & WSP 2033 & $1: 48,000$ & $\begin{array}{l}\text { Computed from specific-capacity data and aquifer tests } \\
\text { for } 5 \text { sites, shown in } \mathrm{ft}^{2} / \mathrm{d} \text { and gal } / \mathrm{d} / \mathrm{ft} \text {. Lines of equal } \\
\text { transmissivity, intervals of } 2,500 \text { and } 3,000 \mathrm{ft}^{2} / \mathrm{d} \text {. For } \\
\text { Lower Pawcatuck Basin. }\end{array}$ \\
\hline Drainage divides................................ & 1974 & WSP 2033 & $1: 48,000$ & For Lower Pawcatuck Basin. \\
\hline Ground-water reservoirs.................. & 1974 & WSP 2033 & $1: 48,000$ & $\begin{array}{l}\text { Yields estimated from mathematical models for } \\
\text { Ashaway and Bradford ground-water reservoirs. }\end{array}$ \\
\hline 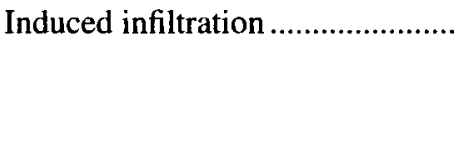 & 1974 & WSP 2033 & $1: 48,000$ & $\begin{array}{l}\text { Vertical hydraulic conductivity of streambed sediments } \\
\text { used to estimate potential recharge by induced } \\
\text { infiltration. For Ashaway and Bradford ground-water } \\
\text { reservoirs. }\end{array}$ \\
\hline \multirow[t]{2}{*}{ Ground-water quality ..................... } & 1953 & GB 6 & $1: 122,000$ & $\begin{array}{l}\text { Major inorganic constituents, physical properties. For } 3 \\
\text { wells. Not on topographic base. }\end{array}$ \\
\hline & 1974 & WSP 2033 & $1: 48,000$ & $\begin{array}{l}\text { Major inorganic constituents, physical properties. For } 3 \\
\text { wells. For Lower Pawcatuck Basin. }\end{array}$ \\
\hline
\end{tabular}


Table 5. Geologic and hydrologic information for the Attleboro Quadrangle

\begin{tabular}{|c|c|c|c|c|}
\hline Information & Date & Publication & Scale & Remarks \\
\hline \multirow[t]{3}{*}{ 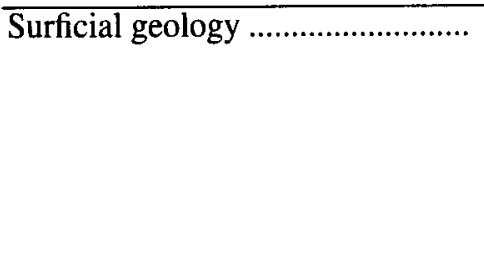 } & 1961 & WSP 1499-A & $1: 125,000$ & $\begin{array}{l}\text { Till and stratified-drift deposits. For northeastern Rhode } \\
\text { Island. }\end{array}$ \\
\hline & 1962 & GWM 19 & $1: 24,000$ & $\begin{array}{l}\text { Shows stratified drift. For Rhode Island part of } \\
\text { quadrangle. }\end{array}$ \\
\hline & 1974 & HB 7 & $1: 24,000$ & $\begin{array}{l}\text { Shows stratified-drift deposits. For Tenmile Basin and } \\
\text { coastal areas. }\end{array}$ \\
\hline \multirow[t]{3}{*}{ 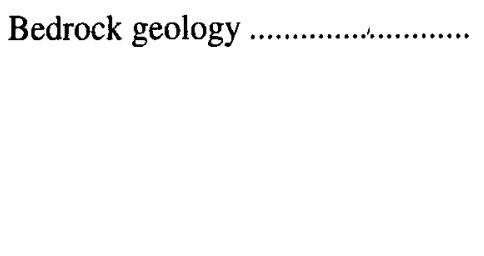 } & 1961 & WSP 1499-A & $1: 362,100$ & $\begin{array}{l}\text { Generalized bedrock map. For northeastern Rhode } \\
\text { Island. }\end{array}$ \\
\hline & 1971 & В 1295 & $1: 125,000$ & Bedrock geologic map of Rhode Island. \\
\hline & 1977 & OFR 77-816 & $1: 31,250$ & $\begin{array}{l}\text { Handwritten information on a topographic base. Plates } \\
\text { on file at U.S. Geological Survey National Center } \\
\text { Library, Reston, Va. }\end{array}$ \\
\hline \multirow[t]{6}{*}{ Subsurface materials ........................ } & 1953 & GB 6 & $1: 122,000$ & $\begin{array}{l}\text { Records of wells and test borings show principal } \\
\text { aquifer. Lithologic log for } 1 \text { well. Not on topographic } \\
\text { base. }\end{array}$ \\
\hline & 1960 & HB 3 & $1: 148,000$ & Lithologic $\log$ for 1 well. \\
\hline & 1961 & WSP 1499-A & $1: 125,000$ & $\begin{array}{l}\text { Shows thickness of stratified-drift deposits in ranges of } \\
<50,50-100 \text {, and }>100 \mathrm{ft} \text {. For northeastern Rhode } \\
\text { Island. }\end{array}$ \\
\hline & 1961 & GB 11 & $1: 62,400$ & $\begin{array}{l}\text { Shows thickness of stratificd-drift deposits in ranges of } \\
0-50,50-100 \text {, and } \geq 100 \mathrm{ft} \text {. For Rhode Island part of } \\
\text { quadrangle. Not on topographic base. }\end{array}$ \\
\hline & 1974 & HB 7 & $1: 24,000$ & $\begin{array}{l}\text { Records of wells and test holes show water-bearing } \\
\text { materials for } 19 \text { wells. Lithologic logs for } 21 \text { wells. } \\
\text { For Tenmile Basin and coastal areas. }\end{array}$ \\
\hline & 1974 & WRIR 4-74 & $1: 24,000$ & $\begin{array}{l}\text { Shows areas where substantial part of saturated zone is } \\
\text { composed of silt and clay. }\end{array}$ \\
\hline \multirow[t]{3}{*}{ Altitude of bedrock surface ............ } & 1953 & GB 6 & $1: 122,000$ & $\begin{array}{l}\text { Records of wells and test borings give land-surface } \\
\text { altitude and depth to bedrock. Not on topographic } \\
\text { base. }\end{array}$ \\
\hline & 1962 & GWM 19 & $1: 24,000$ & $\begin{array}{l}\text { Approximate bedrock contours in stratified drift, } 50 \mathrm{ft} \\
\text { interval. Altitude of bedrock surface shown at well } \\
\text { locations. }\end{array}$ \\
\hline & 1974 & HB 7 & $1: 24,000$ & $\begin{array}{l}\text { Records of wells and test holes give land-surface } \\
\text { altitude and depth to bedrock for } 9 \text { wells. For Tenmile } \\
\text { Basin and coastal areas. }\end{array}$ \\
\hline \multirow[t]{2}{*}{ 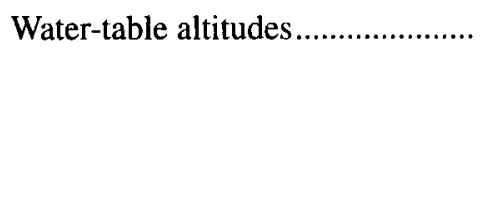 } & 1953 & GB 6 & $1: 122,000$ & $\begin{array}{l}\text { Well records give land-surface altitude and depth to } \\
\text { water. Not on topographic base. }\end{array}$ \\
\hline & 1974 & HB 7 & $1: 24,000$ & $\begin{array}{l}\text { Records of wells and test holes give land-surface } \\
\text { altitude and depth to water for } 17 \text { wells. For Tenmile } \\
\text { Basin and coastal areas. }\end{array}$ \\
\hline 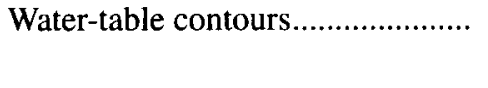 & 1962 & GWM 19 & $1: 24,000$ & $\begin{array}{l}\text { Contours in stratified drift, } 10 \mathrm{ft} \text { interval. Data on wells } \\
\text { collected chiefly in } 1961 \text {. }\end{array}$ \\
\hline Saturated thickness .............................. & 1974 & WRIR 4-74 & $1: 24,000$ & $\begin{array}{l}\text { Lines of equal saturated thickness; } 10,30 \text {, and } 40 \mathrm{ft} \\
\text { intervals. For Abbott Run, Blackstone, and Tenmile } \\
\text { Basins and coastal areas. }\end{array}$ \\
\hline Hydraulic conductivity ....................... & 1960 & HB 3 & $1: 148,000$ & $\begin{array}{l}\text { Computed from aquifer tests on } 1 \text { well. Shown in } \\
\mathrm{gal} / \mathrm{d} / \mathrm{ft}^{2} \text {. }\end{array}$ \\
\hline Transmissivity .................................... & 1960 & HB 3 & $1: 148,000$ & $\begin{array}{l}\text { Computed from aquifer tests on } 1 \text { well. Shown in } \\
\mathrm{gal} / \mathrm{d} / \mathrm{ft} \text {. }\end{array}$ \\
\hline
\end{tabular}


Table 5. Geologic and hydrologic information for the Attleboro Quadrangle--Continued

\begin{tabular}{|c|c|c|c|c|}
\hline Information & Date & Publication & Scale & Remarks \\
\hline Transmissivity--Continued ............. & 1974 & WRIR 4-74 & $1: 24,000$ & $\begin{array}{l}\text { Estimated from lithologic logs, aquifer tests, or specific } \\
\text { capacity data. Shown in intervals of } 4,000 \mathrm{ft}^{2} / \mathrm{d} \\
(30,000 \mathrm{gal} / \mathrm{d} / \mathrm{ft}) \text {. For Abbott Run, Blackstone, and } \\
\text { Tenmile Basins and coastal areas. }\end{array}$ \\
\hline \multirow[t]{2}{*}{ 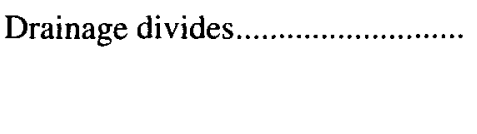 } & 1974 & WRIR 4-74 & $1: 24,000$ & For Abbott Run, Blackstone, and Tenmile Basins. \\
\hline & 1990 & WRIR 89-4164 & $1: 125,000$ & $\begin{array}{l}\text { For Abbott Run and Tenmile Basins. Not on } \\
\text { topographic base. }\end{array}$ \\
\hline Ground-water reservoirs................... & 1974 & WRIR 4-74 & $1: 24,000$ & $\begin{array}{l}\text { Yields estimated from mathematical models for Abbott } \\
\text { Run and Tenmile ground-water reservoirs. }\end{array}$ \\
\hline 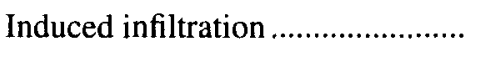 & 1974 & WRIR 4-74 & NA & Discussed for Abbott Run. \\
\hline \multirow[t]{3}{*}{ 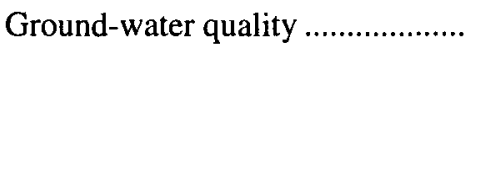 } & 1961 & WSP 1499-A & $1: 125,000$ & $\begin{array}{l}\text { Major inorganic constituents, physical properties. For } 1 \\
\text { well. }\end{array}$ \\
\hline & 1974 & WRIR 4-74 & various & Major inorganic constituents. For 1 well. \\
\hline & 1974 & HB 7 & $1: 24,000$ & Major inorganic constituents. For 1 well. \\
\hline
\end{tabular}


Table 6. Geologic and hydrologic information for the Blackstone Quadrangle

\begin{tabular}{|c|c|c|c|c|}
\hline Information & Date & Publication & Scale & Remarks \\
\hline \multirow[t]{5}{*}{ 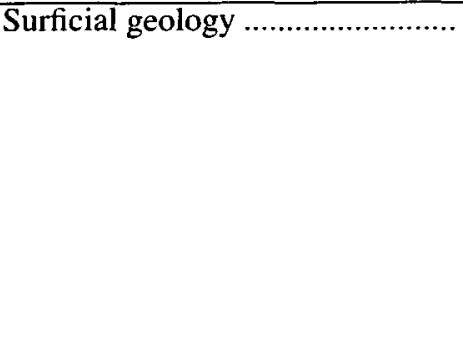 } & 1950 & GB 5 & $1: 15,700$ & $\begin{array}{l}\text { Till and stratified-drift deposits. For the city of } \\
\text { Woonsocket. }\end{array}$ \\
\hline & 1961 & WSP 1499-A & $1: 125,000$ & $\begin{array}{l}\text { Till and stratified-drift deposits. For northeastern Rhode } \\
\text { Island. }\end{array}$ \\
\hline & 1962 & GWM 19 & $1: 24,000$ & $\begin{array}{l}\text { Till and stratified-drift deposits. For Rhode Island part of } \\
\text { quadrangle. }\end{array}$ \\
\hline & 1974 & HB 7 & $1: 24,000$ & Till and stratified-drift deposits. For Blackstone Basin. \\
\hline & 1985 & RAR 1 & $1: 24,000$ & Till and stratified-drift deposits. For Blackstone Basin. \\
\hline \multirow[t]{3}{*}{ Bedrock geology .............................. } & 1950 & GB 5 & $1: 15,700$ & Detailed bedrock map. For the city of Woonsocket. \\
\hline & 1961 & WSP 1499-A & $1: 362,100$ & $\begin{array}{l}\text { Generalized bedrock map shows Pennsylvanian/ } \\
\text { pre-Pennsylvanian contact. For northeastern Rhode } \\
\text { Island. }\end{array}$ \\
\hline & 1971 & В 1295 & $1: 125,000$ & Bedrock geologic map of Rhode Island. \\
\hline \multirow[t]{9}{*}{ Subsurface materials ....................... } & 1950 & GB 5 & $1: 15,700$ & $\begin{array}{l}\text { Well records show materials penetrated for } \\
\text { approximately } 20 \text { wells. }\end{array}$ \\
\hline & & & $1: 12,600$ & Lithologic logs for 34 wells. For the city of Woonsocket. \\
\hline & 1953 & GB 6 & $1: 122,000$ & $\begin{array}{l}\text { Records of wells and test borings show principal aquifer. } \\
\text { Not on topographic base. }\end{array}$ \\
\hline & 1960 & HB 3 & $1: 148,000$ & Lithologic $\log$ for 1 well. \\
\hline & 1961 & WSP 1499-A & $1: 125,000$ & $\begin{array}{l}\text { Shows thickness of stratified-drift deposits in ranges of } \\
<50 \text { and } 50-100 \mathrm{ft} \text {. For northeastern Rhode Island. }\end{array}$ \\
\hline & 1961 & GB 11 & $1: 62,400$ & $\begin{array}{l}\text { Shows stratified-drift deposits in ranges of } 0-50 \text { and } \\
50-100 \mathrm{ft} \text { thick. For Rhode Island part of quadrangle. } \\
\text { Not on topographic base. }\end{array}$ \\
\hline & 1974 & WRIR 18-74 & $1: 24,000$ & Shows areas of till $\geq 40 \mathrm{ft}$ thick. \\
\hline & 1974 & HB 7 & $1: 24,000$ & $\begin{array}{l}\text { Records of wells and test holes show water-bearing } \\
\text { materials for } 17 \text { wells. Lithologic logs for } 46 \text { wells. } \\
\text { For Blackstone Basin. }\end{array}$ \\
\hline & 1974 & WRIR 4-74 & $1: 24,000$ & $\begin{array}{l}\text { Shows areas where substantial part of the saturated zone } \\
\text { is composed of silt and clay. }\end{array}$ \\
\hline \multirow[t]{4}{*}{ Altitude of bedrock surface.......... } & 1950 & GB 5 & $1: 15,700$ & $\begin{array}{l}\text { Well records give land-surface altitude and depth to } \\
\text { bedrock for approximately } 20 \text { wells. Bedrock outcrops } \\
\text { shown. For the city of Woonsocket. }\end{array}$ \\
\hline & 1953 & GB 6 & $1: 122,000$ & $\begin{array}{l}\text { Records of wells and test borings give land-surface } \\
\text { altitude and depth to bedrock. Not on topographic } \\
\text { base. }\end{array}$ \\
\hline & 1962 & GWM 19 & $1: 24,000$ & $\begin{array}{l}\text { Approximate bedrock contours in stratified drift, } 50 \text { and } \\
100 \mathrm{ft} \text { intervals. Altitude of bedrock surface shown at } \\
\text { well locations. Seismic survey lines shown. Bedrock } \\
\text { outcrops in stratified drift shown. }\end{array}$ \\
\hline & 1974 & HB 7 & $1: 24,000$ & $\begin{array}{l}\text { Records of wells and test holes give land-surface altitude } \\
\text { and depth to bedrock for } 32 \text { wells. For Blackstone } \\
\text { Basin. }\end{array}$ \\
\hline \multirow[t]{3}{*}{ 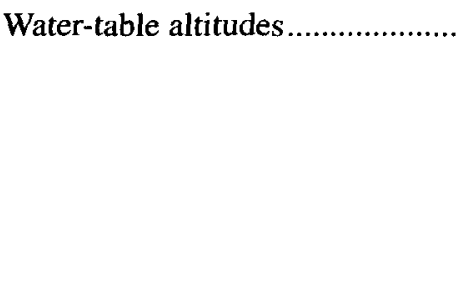 } & 1950 & GB 5 & $1: 15,700$ & $\begin{array}{l}\text { Well records give land-surface altitude and depth to } \\
\text { water for approximately } 20 \text { wells. For the city of } \\
\text { Woonsocket. }\end{array}$ \\
\hline & 1953 & GB 6 & $1: 122,000$ & $\begin{array}{l}\text { Well records give land-surface altitude and depth to } \\
\text { water. Not on topographic base. }\end{array}$ \\
\hline & 1962 & GWM 19 & $1: 24,000$ & $\begin{array}{l}\text { Water-table altitudes shown at well locations. Data on } \\
\text { wells collected chiefly in } 1961 \text {. }\end{array}$ \\
\hline
\end{tabular}


Table 6. Geologic and hydrologic information for the Blackstone Quadrangle--Continued

\begin{tabular}{|c|c|c|c|c|}
\hline Information & Date & Publication & Scale & Remarks \\
\hline \multicolumn{5}{|l|}{ Water-table altitudes-- } \\
\hline 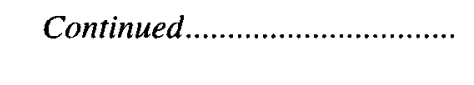 & 1974 & HB 7 & $1: 24,000$ & $\begin{array}{l}\text { Records of wells and test holes give land-surface altitude } \\
\text { and depth to water for } 51 \text { wells. For Blackstone Basin. }\end{array}$ \\
\hline \multirow[t]{2}{*}{ 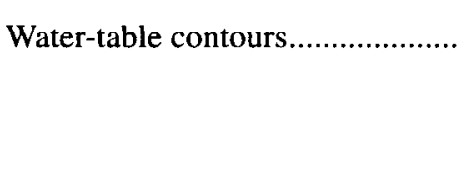 } & 1962 & GWM 19 & $1: 24,000$ & $\begin{array}{l}\text { Approximate contours in stratified drift, } 20 \mathrm{ft} \text { interval. } \\
\text { Data on wells collected chiefly in } 1961 .\end{array}$ \\
\hline & 1985 & RAR 1 & $1: 24,000$ & $\begin{array}{l}\text { Water-table contours, } 10 \mathrm{ft} \text { interval. For Blackstone } \\
\text { Basin. }\end{array}$ \\
\hline \multirow[t]{2}{*}{ 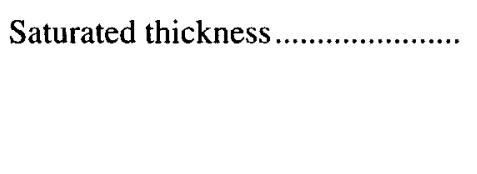 } & 1974 & WRIR 4-74 & $1: 24,000$ & $\begin{array}{l}\text { Lines of equal saturated thickness; } 10,30 \text {, and } 40 \mathrm{ft} \\
\text { intervals. For Blackstone Basin. }\end{array}$ \\
\hline & 1974 & WRIR 18-74 & $1: 24,000$ & $\begin{array}{l}\text { Lines of equal saturated thickness, } 20 \mathrm{ft} \text { interval. For } \\
\text { Branch Basin. }\end{array}$ \\
\hline Hydraulic conductivity ..................... & 1960 & HB 3 & $1: 148,000$ & $\begin{array}{l}\text { Computed from aquifer test on } 1 \text { well. Shown in } \\
\mathrm{gal} / \mathrm{d} / \mathrm{ft}^{2} \text {. }\end{array}$ \\
\hline \multirow[t]{3}{*}{ 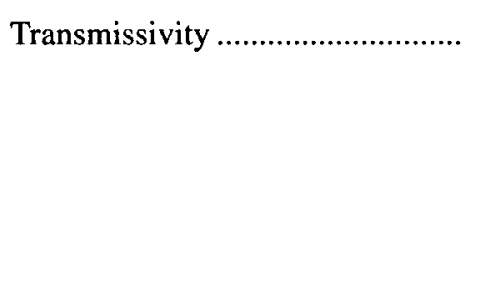 } & 1960 & HB 3 & $1: 148,000$ & $\begin{array}{l}\text { Computed from aquifer test on } 1 \text { well. Shown in } \\
\mathrm{gal} / \mathrm{d} / \mathrm{ft} \text {. }\end{array}$ \\
\hline & 1974 & WRIR 18-74 & $1: 24,000$ & $\begin{array}{l}\text { Estimated from lithologic logs. Shown in intervals of } \\
2,500 \text { and } 3,000 \mathrm{ft}^{2} / \mathrm{d} \text {. For Branch Basin. }\end{array}$ \\
\hline & 1974 & WRIR 4-74 & $1: 24,000$ & $\begin{array}{l}\text { Estimated from lithologic logs, aquifer tests, or specific } \\
\text { capacity data. Shown in intervals of } 4,000 \mathrm{ft}^{2} / \mathrm{d} \\
(30,000 \mathrm{gal} / \mathrm{d} / \mathrm{ft}) . \text { For Blackstone Basin. }\end{array}$ \\
\hline \multirow[t]{4}{*}{ Drainage divides............................. } & 1974 & WRIR 18-74 & $1: 24,000$ & For Branch Basin. \\
\hline & 1974 & HB 7 & $1: 24,000$ & For Branch Basin. \\
\hline & 1974 & WRIR 4-74 & $1: 24,000$ & For Branch Basin. \\
\hline & 1990 & WRIR $89-4164$ & $1: 125,000$ & $\begin{array}{l}\text { For Blackstone and Branch Basins. Not on topographic } \\
\text { base. }\end{array}$ \\
\hline 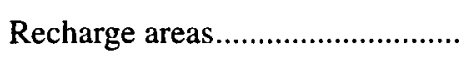 & 1985 & RAR 1 & $1: 24,000$ & For Blackstone ground-water reservoir. \\
\hline \multirow[t]{2}{*}{ Ground-water reservoirs................ } & 1974 & WRIR 4-74 & $1: 24,000$ & $\begin{array}{l}\text { Yields estimated from analytical models for Lower } \\
\text { Branch-Blackstone and Blackstone ground-water } \\
\text { reservoirs. }\end{array}$ \\
\hline & 1985 & RAR 1 & $1: 24,000$ & Shows Blackstone ground-water reservoir. \\
\hline \multirow[t]{5}{*}{ Ground-water quality ..................... } & 1950 & GB 5 & $1: 15,700$ & $\begin{array}{l}\text { Major inorganic constituents, physical properties; for } 1 \\
\text { well. Hardness for several wells. For the city of Woon- } \\
\text { socket. }\end{array}$ \\
\hline & 1953 & GB 6 & $1: 122,000$ & $\begin{array}{l}\text { Major inorganic constituents, physical properties. For } 3 \\
\text { wells. Not on topographic base. }\end{array}$ \\
\hline & 1974 & HB 7 & $1: 24,000$ & $\begin{array}{l}\text { Major inorganic constituents, physical properties. For } 6 \\
\text { wells. For Blackstone Basin. }\end{array}$ \\
\hline & 1974 & WRIR 4-74 & $1: 156,000$ & $\begin{array}{l}\text { Dissolved solids, iron, and manganese trends for } 1 \text { well. } \\
\text { For Blackstone Basin. }\end{array}$ \\
\hline & 1974 & WRIR 18-74 & $1: 133,300$ & $\begin{array}{l}\text { Major inorganic constituents, physical properties. For } 1 \\
\text { well. For Branch Basin. }\end{array}$ \\
\hline
\end{tabular}


Table 7. Geologic and hydrologic information for the Block Island Quadrangle

\begin{tabular}{|c|c|c|c|c|}
\hline Information & Date & Publication & Scale & Remarks \\
\hline 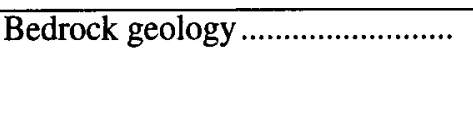 & 1971 & B 1295 & $1: 125,000$ & $\begin{array}{l}\text { Bedrock geologic map of Rhode Island. Shows } \\
\text { exposures of unconsolidated Cretaceous rocks on } \\
\text { Block Island. }\end{array}$ \\
\hline \multirow[t]{4}{*}{ Subsurface materials ...................... } & 1953 & GB 6 & $1: 122,000$ & $\begin{array}{l}\text { Records of wells and test borings show principal } \\
\text { aquifer. Not on topographic base. }\end{array}$ \\
\hline & 1961 & PP 424-C & NA & $\begin{array}{l}\text { Subsurface profile showing thickness of weathered, } \\
\text { unconsolidated, and semi-consolidated zones, and } \\
\text { depth to crystalline zone. From seismic surveys. }\end{array}$ \\
\hline & 1964 & GB 14 & $\begin{array}{l}1: 15,000 \\
1: 8,000\end{array}$ & $\begin{array}{l}\text { Records of selected wells show aquifer material. } \\
\text { Lithologic logs for } 29 \text { wells and test holes. } \\
\text { Generalized geologic sections. Well locations not } \\
\text { on topographic base. }\end{array}$ \\
\hline & 1993 & OFR 92-155 & $1: 12,000$ & Lithologic logs for 375 wells and test borings. \\
\hline \multirow[t]{3}{*}{ 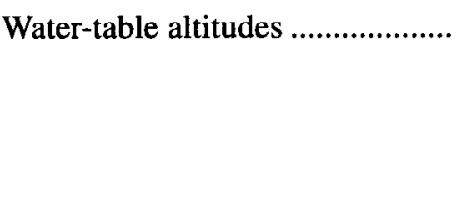 } & 1953 & GB 6 & $1: 122,000$ & $\begin{array}{l}\text { Well records give land-surface altitude and depth to } \\
\text { water. Not on topographic base. }\end{array}$ \\
\hline & 1964 & GB 14 & $\begin{array}{l}1: 15,000 \\
1: 8,000\end{array}$ & $\begin{array}{l}\text { Well records give land-surface altitude and depth to } \\
\text { water. }\end{array}$ \\
\hline & 1993 & OFR 92-155 & $1: 12,000$ & Water-level measurements for 159 wells. \\
\hline \multirow[t]{2}{*}{ 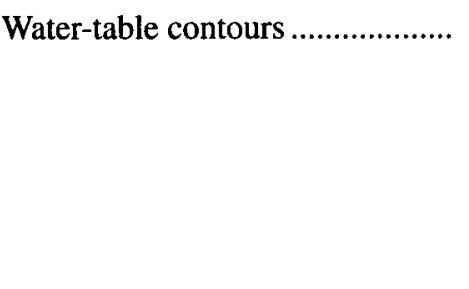 } & 1964 & GB 14 & $1: 56,320$ & $\begin{array}{l}\text { Contours in lower perched zone, } 25 \mathrm{ft} \text { interval. Contours } \\
\text { in main zone of saturation, } 3 \mathrm{ft} \text { interval, September } \\
\text { 1962. Not on topographic base. }\end{array}$ \\
\hline & 1994 & OFR 92-49 & $1: 12,000$ & $\begin{array}{l}\text { Generalized water-table contours in glacial deposits, } 20 \\
\mathrm{ft} \text { interval. Water-table altitudes shown at locations } \\
\text { for } 117 \text { shallow wells (less than } 35 \mathrm{ft} \text { deep). Data } \\
\text { collected } 1962,1988-90 .\end{array}$ \\
\hline 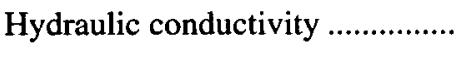 & 1964 & GB 14 & $\begin{array}{l}1: 15,000 \\
1: 8,000\end{array}$ & $\begin{array}{l}\text { Computed from aquifer tests on } 13 \text { wells. Shown in } \\
\mathrm{gal} / \mathrm{d} / \mathrm{ft}^{2} \text {. }\end{array}$ \\
\hline 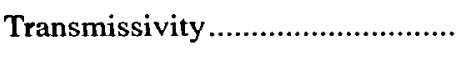 & 1964 & GB 14 & $\begin{array}{l}1: 15,000 \\
1: 8,000\end{array}$ & $\begin{array}{l}\text { Computed from aquifer tests on } 13 \text { wells. Shown in } \\
\mathrm{gal} / \mathrm{d} / \mathrm{ft} \text {. }\end{array}$ \\
\hline \multirow[t]{3}{*}{ 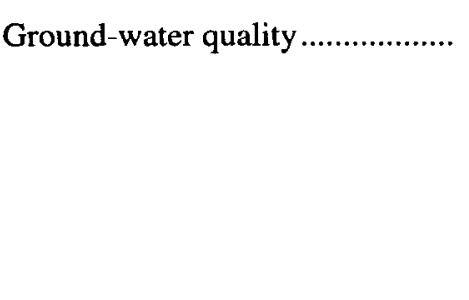 } & 1953 & GB 6 & $1: 122,000$ & $\begin{array}{l}\text { Major inorganic constituents, physical properties. For } 1 \\
\text { well. Not on topographic base. }\end{array}$ \\
\hline & 1964 & GB 14 & $\begin{array}{l}1: 15,000 \\
1: 8,000 \\
1: 56,320\end{array}$ & $\begin{array}{l}\text { Major inorganic constituents, physical properties, for } 47 \\
\text { wells. Maps in text show chloride concentrations. } \\
\text { Temperature and chloride values for additional wells. }\end{array}$ \\
\hline & 1993 & OFR 92-155 & $1: 12,000$ & $\begin{array}{l}\text { Data for } 150 \text { samples. Specific conductance for } 52 \\
\text { wells. Data for public-supply wells, } 1976-91 \text {. }\end{array}$ \\
\hline
\end{tabular}


Table 8. Geologic and hydrologic information for the Bristol Quadrangle

\begin{tabular}{|c|c|c|c|c|}
\hline Information & Date & Publication & Scale & Remarks \\
\hline \multirow[t]{4}{*}{ Surficial geology ........................... } & 1950 & $\mathrm{SC} 3$ & $1: 33,500$ & $\begin{array}{l}\text { Till and stratified-drift deposits. For towns of Barrington, } \\
\text { Warren, and Bristol. }\end{array}$ \\
\hline & 1954 & GB 7 & $1: 31,680$ & Till and stratified-drift deposits. \\
\hline & 1955 & GQ 70 & $1: 31,680$ & Detailed surficial map. Geology mapped in 1950. \\
\hline & 1961 & WSP 1499-A & $1: 125,000$ & $\begin{array}{l}\text { Till and stratified-drift deposits. For northeastern Rhode } \\
\text { Island. }\end{array}$ \\
\hline \multirow[t]{5}{*}{ 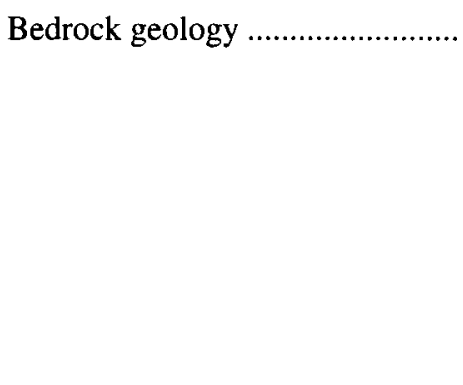 } & 1954 & GQ 42 & $1: 31,680$ & Detailed bedrock map. Geology mapped 1952. \\
\hline & 1954 & GB 7 & $1: 31,680$ & $\begin{array}{l}\text { Approximate contact between Carboniferous and } \\
\text { pre-Carboniferous bedrock. }\end{array}$ \\
\hline & 1961 & WSP 1499-A & $1: 362,100$ & $\begin{array}{l}\text { Generalized bedrock map shows Pennsylvanian/ } \\
\text { pre-Pennsylvanian contact. For northeastern Rhode } \\
\text { Island. }\end{array}$ \\
\hline & 1971 & B 1295 & $1: 125,000$ & Bedrock geologic map of Rhode Island. \\
\hline & 1979 & WSP 2062 & NA & $\begin{array}{l}\text { Information on bedrock from geophysical logs. For } 3 \\
\text { wells. }\end{array}$ \\
\hline \multirow[t]{6}{*}{ Subsurface materials .................... } & 1950 & $\mathrm{SC} 3$ & $1: 33,500$ & $\begin{array}{l}\text { Well records show materials penetrated. For } 157 \text { wells. For } \\
\text { towns of Barrington, Warren, and Bristol. }\end{array}$ \\
\hline & 1953 & GB 6 & $1: 122,000$ & $\begin{array}{l}\text { Records of wells and test borings show principal aquifer. } \\
\text { Lithologic logs for } 7 \text { wells. Not on topographic base. }\end{array}$ \\
\hline & 1954 & GB 7 & $1: 31,680$ & $\begin{array}{l}\text { Records of wells and test borings show principal aquifer } \\
\text { for approximately } 180 \text { wells and test borings. Lithologic } \\
\text { logs for } 17 \text { wells. Gencralized gcologic sections. }\end{array}$ \\
\hline & 1960 & HB 3 & $1: 148,000$ & Lithologic logs for 2 wells. \\
\hline & 1961 & WSP 1499-A & $1: 125,000$ & $\begin{array}{l}\text { Shows thickness of stratified-drift deposits in ranges of } \\
<50,50-100 \text {, and }>100 \mathrm{ft} \text {. For northeastern Rhode } \\
\text { Island. }\end{array}$ \\
\hline & 1961 & GB 11 & $1: 62,400$ & $\begin{array}{l}\text { Shows thickness of stratified-drift deposits in ranges of } \\
0-50,50-100 \text {, and } \geq 100 \mathrm{ft} \text {. Not on topographic base. }\end{array}$ \\
\hline \multirow[t]{3}{*}{ Altitude of bedrock surface ......... } & 1950 & $\mathrm{SC} 3$ & $1: 33,500$ & $\begin{array}{l}\text { Well records give approximate altitude of bedrock surface. } \\
\text { For } 51 \text { wells. For towns of Barrington, Warren, and } \\
\text { Bristol. }\end{array}$ \\
\hline & 1953 & GB 6 & $1: 122,000$ & $\begin{array}{l}\text { Records of wells and test borings give land-surface alitude } \\
\text { and depth to bedrock. Not on topographic base. }\end{array}$ \\
\hline & 1954 & GB 7 & $1: 31,680$ & $\begin{array}{l}\text { Approximate bedrock contours in stratified drift, } 50 \mathrm{ft} \\
\text { interval. Bedrock altitude at well locations. Bedrock } \\
\text { outcrops in stratified drift shown. }\end{array}$ \\
\hline \multirow[t]{3}{*}{ Water-table altitudes ..................... } & 1950 & SC 3 & $1: 33,500$ & $\begin{array}{l}\text { Well records give approximate land-surface altitude and } \\
\text { depth to water. For } 48 \text { wells. For towns of Barrington, } \\
\text { Warren, and Bristol. }\end{array}$ \\
\hline & 1953 & GB 6 & $1: 122,000$ & $\begin{array}{l}\text { Well records give land-surface altitude and depth to water. } \\
\text { Not on topographic base. }\end{array}$ \\
\hline & 1954 & GB 7 & $1: 31,680$ & $\begin{array}{l}\text { Well records give land-surface altitude and depth to water. } \\
\text { For approximately } 100 \text { wells. }\end{array}$ \\
\hline Saturated thickness ............................ & 1954 & GB 7 & $1: 31,680$ & $\begin{array}{l}\text { Can be estimated from depth to bedrock and depth to } \\
\text { water at some well locations. }\end{array}$ \\
\hline Hydraulic conductivity ................ & 1960 & HB 3 & $1: 148,000$ & $\begin{array}{l}\text { Computed from aquifer tests on } 2 \text { wells. Shown in } \\
\mathrm{gal} / \mathrm{d} / \mathrm{ft}^{2} \text {. }\end{array}$ \\
\hline 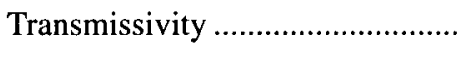 & 1954 & GB 7 & $1: 31,680$ & $\begin{array}{l}\text { Computed from aquifer tests on } 2 \text { wells. Shown in } \\
\mathrm{gal} / \mathrm{d} / \mathrm{ft} \text {. }\end{array}$ \\
\hline
\end{tabular}


Table 8. Geologic and hydrologic information for the Bristol Quadrangle--Continued

\begin{tabular}{|c|c|c|c|c|}
\hline Information & Date & Publication & Scale & Remarks \\
\hline \multirow[t]{2}{*}{ Transmissivity--Continued............ } & 1960 & HB 3 & $1: 148,000$ & $\begin{array}{l}\text { Computed from aquifer tests on } 2 \text { wells. Shown in } \\
\mathrm{gal} / \mathrm{d} / \mathrm{ft} \text {. }\end{array}$ \\
\hline & 1979 & WSP 2062 & NA & Specific-capacity data from aquifer tests on 2 wells. \\
\hline \multirow[t]{5}{*}{ Ground-water quality ....................... } & 1950 & SC 3 & $1: 33,500$ & $\begin{array}{l}\text { Major inorganic constituents for } 7 \text { wells. Saltwater } \\
\text { intrusion discussed. For towns of Barrington, Warren, } \\
\text { and Bristol. }\end{array}$ \\
\hline & 1953 & GB 6 & $1: 122,000$ & $\begin{array}{l}\text { Major inorganic constituents, physical properties. For } 5 \\
\text { wells. Not on topographic base. }\end{array}$ \\
\hline & 1954 & GB 7 & $1: 31,680$ & $\begin{array}{l}\text { Major inorganic constituents, physical properties. For } 16 \\
\text { wells. }\end{array}$ \\
\hline & 1961 & WSP 1499-A & $1: 125,000$ & $\begin{array}{l}\text { Major inorganic constituents, physical properties. For } 4 \\
\text { wells. }\end{array}$ \\
\hline & 1979 & WSP 2062 & NA & $\begin{array}{l}\text { Temperature and specific conductance for } 3 \text { wells. } \\
\text { Discussion of saltwater intrusion. }\end{array}$ \\
\hline
\end{tabular}


Table 9. Geologic and hydrologic information for the Carolina Quadrangle

\begin{tabular}{|c|c|c|c|c|}
\hline Information & Date & Publication & Scale & Remarks \\
\hline \multirow[t]{7}{*}{ 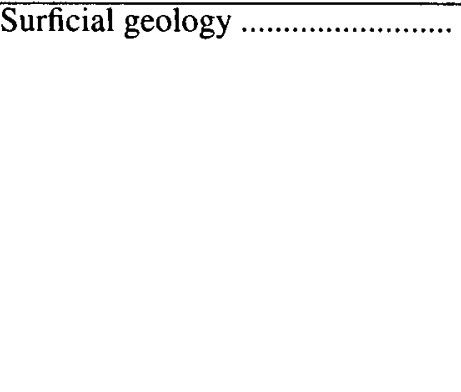 } & 1960 & GWM 9 & $1: 24,000$ & Till, stratified drift, and mixed deposits. \\
\hline & 1977 & WISR 3 & $1: 12,000$ & $\begin{array}{l}\text { Till, stratified drift, and mixed deposits. For Beaver- } \\
\text { Pasquiset Basin. }\end{array}$ \\
\hline & 1980 & WISR 4 & $1: 12,000$ & Till and stratified-drift, deposits. For Lower Wood Basin. \\
\hline & 1985 & WRIR $85-4190$ & $1: 36,200$ & $\begin{array}{l}\text { Till, stratified drift, and mixed deposits. For Beaver- } \\
\text { Pasquiset Basin. }\end{array}$ \\
\hline & 1989 & WISR 5 & $1: 24,000$ & Till and stratified-drift deposits. For Upper Wood Basin. \\
\hline & 1990 & WRIR 89-4031 & $1: 44,100$ & Till and stratified-drift deposits. For Lower Wood Basin. \\
\hline & 1993 & WRIR 92-4119 & $1: 68,700$ & Till and stratified-drift deposits. For Upper Wood Basin. \\
\hline \multirow[t]{2}{*}{ Bedrock geology . } & 1959 & GQ 117 & $1: 31,680$ & $\begin{array}{l}\text { Detailed bedrock map. Geology mapped in } 1953,1954 \text {, } \\
\text { and } 1956 .\end{array}$ \\
\hline & 1971 & B 1295 & $1: 125,000$ & Bedrock geologic map of Rhode Island. \\
\hline \multirow[t]{9}{*}{ 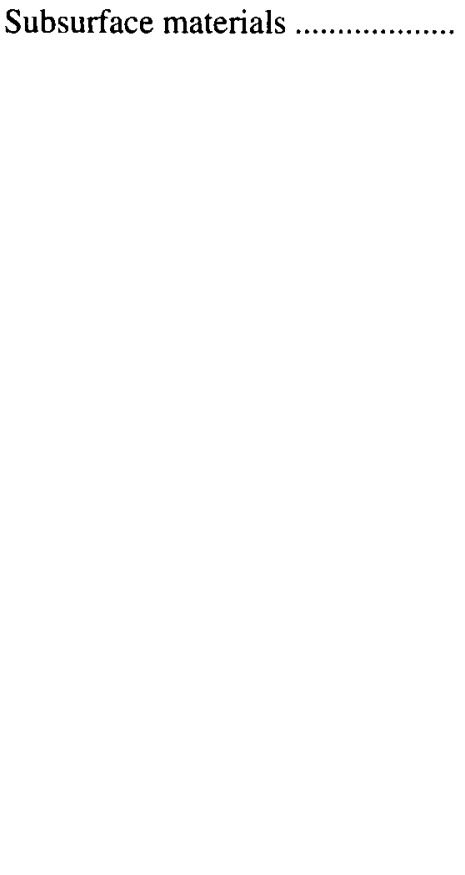 } & 1953 & GB 6 & $1: 122,000$ & $\begin{array}{l}\text { Records of wells and test borings show principal aquifer. } \\
\text { Not on topographic base. }\end{array}$ \\
\hline & 1961 & GB 11 & $1: 61,400$ & $\begin{array}{l}\text { Shows thickness of stratified-drift deposits in ranges of } \\
0-50,50-100 \text {, and } \geq 100 \mathrm{ft} \text {. Not on topographic base. }\end{array}$ \\
\hline & 1974 & WSP 2033 & $1: 48,000$ & $\begin{array}{l}\text { Map shows areas where silt or clay layers are reported to } \\
\text { separate water-bearing sand and gravel layers. }\end{array}$ \\
\hline & 1977 & WISR 3 & $1: 12,000$ & $\begin{array}{l}\text { Records of wells and test holes show water-bearing } \\
\text { materials for approximately } 120 \text { wells. Lithologic logs } \\
\text { for approximately } 90 \text { wells. For Beaver-Pasquiset } \\
\text { Basin. }\end{array}$ \\
\hline & 1980 & WISR 4 & $1: 12,000$ & $\begin{array}{l}\text { Records of wells and test holes show water-bearing } \\
\text { materials for approximately } 300 \text { wells. Lithologic logs } \\
\text { for approximately } 190 \text { wells. For Lower Wood Basin. }\end{array}$ \\
\hline & 1985 & OFR 84-725 & $1: 2,400$ & $\begin{array}{l}\text { Detailed lithologic logs for approximately } 165 \text { wells and } \\
\text { test holes. For area near Wood River Junction. Not on } \\
\text { topographic base. }\end{array}$ \\
\hline & 1985 & WRIR 85-4190 & various & $\begin{array}{l}\text { Generalized geologic sections. Lithologic logs for several } \\
\text { wells. For Bcaver-Pasquiset Basin. }\end{array}$ \\
\hline & 1989 & WISR 5 & $1: 24,000$ & $\begin{array}{l}\text { Records of wells and test holes show principal water- } \\
\text { bearing material. For } 2 \text { wells. For Upper Wood Basin. }\end{array}$ \\
\hline & 1990 & WRIR 89-4031 & NA & Generalized geologic sections. For Lower Wood Basin. \\
\hline \multirow[t]{7}{*}{ Altitude of bedrock surface ........... } & 1953 & GB 6 & $1: 122,000$ & $\begin{array}{l}\text { Records of wells and test borings give land-surface } \\
\text { altitude and depth to bedrock. Not on topographic base. }\end{array}$ \\
\hline & 1960 & GWM 9 & $1: 24,000$ & $\begin{array}{l}\text { Approximate bedrock contours in stratified drift and } \\
\text { mixed deposits, } 50 \mathrm{ft} \text { interval. Altitude of bedrock } \\
\text { surface shown at well locations. Some bedrock } \\
\text { altitudes determined by seismic survey. Bedrock } \\
\text { outcrops in stratified drift and mixed deposits shown. }\end{array}$ \\
\hline & 1963 & GB 13 & $1: 24,000$ & From seismic data. \\
\hline & 1974 & WSP 2033 & $1: 48,000$ & $\begin{array}{l}\text { Approximate bedrock contours, } 50 \mathrm{ft} \text { interval. For Lower } \\
\text { Pawcatuck Basin. }\end{array}$ \\
\hline & 1977 & WISR 3 & $1: 12,000$ & $\begin{array}{l}\text { Records of wells and test holes give land-surface altitude } \\
\text { and depth to bedrock surface. For several wells. For } \\
\text { Beaver-Pasquiset Basin. }\end{array}$ \\
\hline & 1980 & WISR 4 & $1: 12,000$ & $\begin{array}{l}\text { Well records give land-surface altitude and depth to } \\
\text { bedrock. For } 40 \text { wells. For Lower Wood Basin. }\end{array}$ \\
\hline & 1985 & OFR $84-725$ & $1: 27,000$ & $\begin{array}{l}\text { From seismic refraction data. For area near Wood River } \\
\text { Junction. }\end{array}$ \\
\hline
\end{tabular}


Table 9. Geologic and hydrologic information for the Carolina Quadrangle--Continued

\begin{tabular}{|c|c|c|c|c|}
\hline Information & Date & Publication & Scale & Remarks \\
\hline \multirow[t]{2}{*}{ 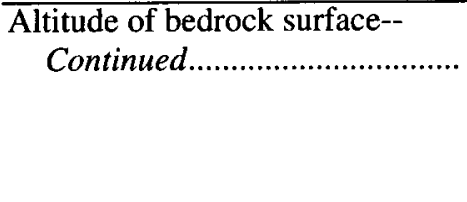 } & 1985 & WRIR 85-4190 & various & $\begin{array}{l}\text { Generalized geologic sections show depth to bedrock. } \\
\text { For Beaver-Pasquiset Basin. }\end{array}$ \\
\hline & 1990 & WRIR 89-4031 & NA & $\begin{array}{l}\text { Shown in generalized geologic sections. For Lower } \\
\text { Wood Basin. }\end{array}$ \\
\hline \multirow[t]{6}{*}{ Water-table altitudes...... } & 1953 & GB 6 & $1: 122,000$ & $\begin{array}{l}\text { Well records give land-surface altitude and depth to } \\
\text { water. Not on topographic base. }\end{array}$ \\
\hline & 1960 & GWM 9 & $1: 24,000$ & $\begin{array}{l}\text { Water-table altitudes shown at well locations. Data on } \\
\text { wells collected chiefly in } 1955 .\end{array}$ \\
\hline & 1977 & WISR 3 & $1: 12,000$ & $\begin{array}{l}\text { Records of wells and test holes give land-surface altitude } \\
\text { and depth to water. For approximately } 100 \text { wells. For } \\
\text { Beaver-Pasquiset Basin. }\end{array}$ \\
\hline & 1980 & WISR 4 & $1: 12,000$ & $\begin{array}{l}\text { Records of wells and test holes give land-surface altitude } \\
\text { and depth to water. For approximately } 360 \text { wells. For } \\
\text { Lower Wood Basin. }\end{array}$ \\
\hline & 1985 & OFR $84-725$ & $1: 2,400$ & $\begin{array}{l}\text { Tables show land-surface altitude and depth to water. } \\
\text { Monthly or intermittent water levels from December } \\
1978 \text { to December } 1983 \text {. For } 137 \text { wells. For area near } \\
\text { Wood River Junction. Not on topographic base. }\end{array}$ \\
\hline & 1989 & WISR 5 & $1: 24,000$ & $\begin{array}{l}\text { Records of wells and test holes give land-surface altitude } \\
\text { and depth to water. For } 2 \text { wells. For Upper Wood } \\
\text { Basin. }\end{array}$ \\
\hline \multirow[t]{6}{*}{ 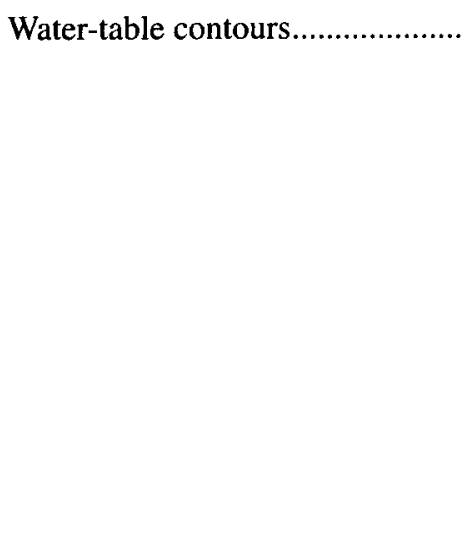 } & 1960 & GWM 9 & $1: 24,000$ & $\begin{array}{l}\text { Approximate water-table contours in stratified drift and } \\
\text { mixed deposits, } 10 \text { and } 20 \mathrm{ft} \text { intervals. Data on wells } \\
\text { collected chiefly in } 1955 .\end{array}$ \\
\hline & 1974 & WSP 2033 & $1: 48,000$ & $\begin{array}{l}\text { Water-table contours in stratified drift, } 10 \mathrm{ft} \text { interval. For } \\
\text { Lower Pawcatuck Basin. }\end{array}$ \\
\hline & 1985 & WSP 2270 & various & $\begin{array}{l}\text { For area near Wood River Junction, } 2 \mathrm{ft} \text { interval. July } \\
1982 \text { to June } 1983 \text {. Not on topographic base }\end{array}$ \\
\hline & 1985 & WRIR $85-4190$ & $1: 36,200$ & $\begin{array}{l}\text { Water-table contours in stratified drift, } 5 \text { to } 10 \mathrm{ft} \text { intervals. } \\
\text { August-November, 1975. For Beaver-Pasquiset Basin. }\end{array}$ \\
\hline & 1990 & WRIR 89-4031 & $1: 44,100$ & $\begin{array}{l}\text { Water-table contours in stratified drift, } 5 \text { and } 10 \mathrm{ft} \\
\text { intervals. For Lower Wood Basin. }\end{array}$ \\
\hline & 1993 & WRIR 92-4119 & $1: 54,100$ & $\begin{array}{l}\text { Water-table contours in stratified drift, } 10 \mathrm{ft} \text { interval. For } \\
\text { Upper Wood Basin. Not on topographic base. }\end{array}$ \\
\hline \multirow[t]{4}{*}{ 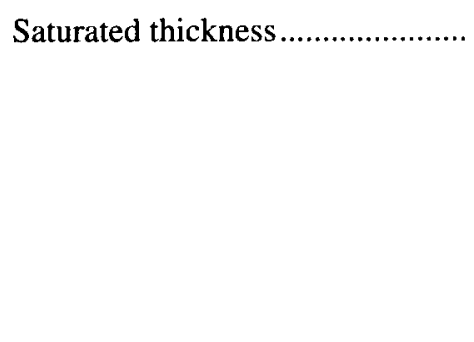 } & 1974 & WSP 2033 & $1: 48,000$ & $\begin{array}{l}\text { Lines of equal saturated thickness, } 20 \mathrm{ft} \text { interval. For } \\
\text { Lower Pawcatuck Basin. }\end{array}$ \\
\hline & 1985 & WRIR $85-4190$ & $1: 36,200$ & $\begin{array}{l}\text { Lines of equal saturated thickness, } 20 \mathrm{ft} \text { interval. For } \\
\text { Beaver-Pasquiset Basin. Not on topographic base. }\end{array}$ \\
\hline & 1990 & WRIR 89-4031 & $1: 44,100$ & $\begin{array}{l}\text { Lines of equal saturated thickness, } 20 \mathrm{ft} \text { interval. For } \\
\text { Lower Wood Basin. Not on topographic base. }\end{array}$ \\
\hline & 1993 & WRIR 92-4119 & $1: 54,100$ & $\begin{array}{l}\text { Lines of equal saturated thickness, } 20 \mathrm{ft} \text { interval. For } \\
\text { Upper Wood Basin. Not on topographic base. }\end{array}$ \\
\hline Hydraulic conductivity ...................... & 1990 & WRIR 89-4031 & NA & $\begin{array}{l}\text { Estimated from lithologic } \log \text { for } 1 \text { well. Range of values } \\
\text { for horizontal and vertical hydraulic conductivity } \\
\text { estimated from aquifer test data for } 11 \text { wells. Shown in } \\
\mathrm{ft} / \mathrm{d} \text {. For Lower Wood Basin. }\end{array}$ \\
\hline \multirow[t]{2}{*}{ 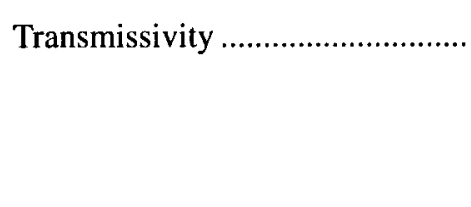 } & 1974 & WSP 2033 & $1: 48,000^{1}$ & $\begin{array}{l}\text { Map shows lines of equal transmissivity, intervals of } \\
2,500 \text { and } 3,000 \mathrm{ft}^{2} / \mathrm{d} \text {. For Lower Pawcatuck Basin. }\end{array}$ \\
\hline & 1985 & WRIR 85-4190 & $1: 36,200$ & $\begin{array}{l}\text { Lines of equal transmissivity, interval of } 3,000 \mathrm{ft}^{2} / \mathrm{d} \text {. For } \\
\text { Beaver-Pasquiset Basin. Not on topographic base. } \\
\text { Estimated from lithologic logs and aquifer test data. }\end{array}$ \\
\hline
\end{tabular}


Table 9. Geologic and hydrologic information for the Carolina Quadrangle--Continued

\begin{tabular}{|c|c|c|c|c|}
\hline Information & Date & Publication & Scale & Remarks \\
\hline \multirow[t]{3}{*}{ 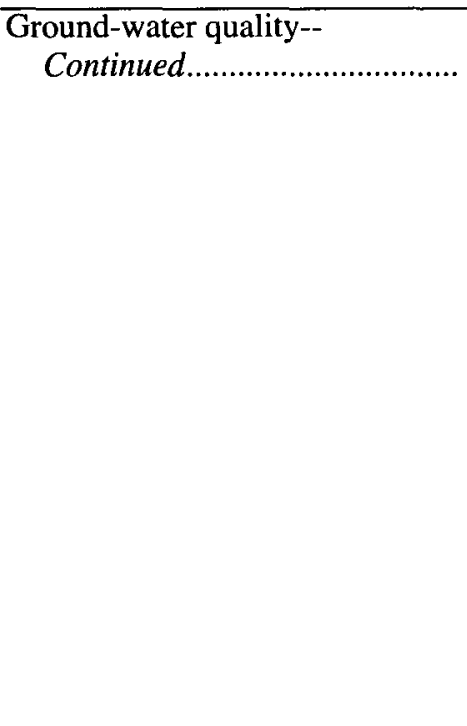 } & 1985 & OFR 84-725 & $1: 2,400$ & $\begin{array}{l}\text { Major inorganic constituents, trace metals, physical } \\
\text { properties, detergents, nutrients, radiochemical } \\
\text { constituents, other minor elements. Data collected } \\
\text { chiefly April 1981-June 1983. For approximately } 120 \\
\text { wells. For area near Wood River Junction. Not on } \\
\text { topographic base. }\end{array}$ \\
\hline & 1985 & WSP 2270 & various & $\begin{array}{l}\text { Maps and cross-sections showing concentrations of } \\
\text { strontium-90 and nitrate and values of specific } \\
\text { conductance. }\end{array}$ \\
\hline & 1990 & WRIR 89-4031 & NA & $\begin{array}{l}\text { Summary of major inorganic constituents, physical } \\
\text { properties. Iron, manganese, dissolved oxygen, and } \\
\text { specific conductance data for } 4 \text { wells, 1976-77. } \\
\text { Pesticide data for } 11 \text { wells, } 1984-85 \text {. Lines of equal } \\
\text { concentration of total aldicarb residues, } 1984-85 \text {, } \\
\text { shown in hydrologic sections; interval } 25 \mu \mathrm{g} / \mathrm{L} \text {. } \\
\text { Selected data for low-level radionuclide contamination } \\
\text { site, 1981-82. For Lower Wood Basin. }\end{array}$ \\
\hline
\end{tabular}

${ }^{1}$ Computed from specific capacity data for 4 sites, shown in $\mathrm{ft}^{2} / \mathrm{d}$ and $\mathrm{gal} / \mathrm{d} / \mathrm{ft}$. 
Table 10. Geologic and hydrologic information for the Chepachet Quadrangle

\begin{tabular}{|c|c|c|c|c|}
\hline Information & Date & Publication & Scale & Remarks \\
\hline \multirow[t]{2}{*}{ Surficial geology .............................. } & 1961 & GWM 15 & $1: 24,000$ & Till and stratified-drift deposits. \\
\hline & 1961 & GB 12 & $1: 24,800$ & $\begin{array}{l}\text { Till and stratified-drift deposits. Not on topographic base. } \\
\text { For Wallum Lake study area. }\end{array}$ \\
\hline \multirow[t]{2}{*}{ Bedrock geology ............................. } & 1967 & B 1241-G & $1: 24,000$ & $\begin{array}{l}\text { Detailed bedrock map. Geology mapped in 1956-57 and } \\
1962-64 \text {. }\end{array}$ \\
\hline & 1971 & В 1295 & $1: 125,000$ & Bedrock geologic map of Rhode Island. \\
\hline \multirow[t]{5}{*}{ 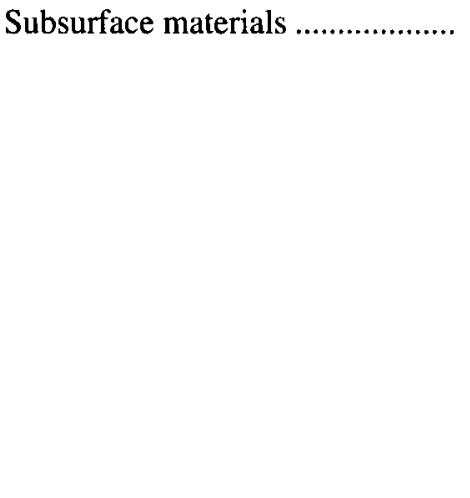 } & 1953 & GB 6 & $1: 122,000$ & $\begin{array}{l}\text { Records of wells and test borings show principal aquifer. } \\
\text { Lithologic logs for } 3 \text { wells. Not on topographic base. }\end{array}$ \\
\hline & 1960 & HB 3 & $1: 148,000$ & Lithologic $\log$ for 1 well. \\
\hline & 1961 & GB 11 & $1: 38,300$ & $\begin{array}{l}\text { Shows stratified-drift deposits } 0-50 \mathrm{ft} \text { thick. Not on } \\
\text { topographic base. }\end{array}$ \\
\hline & 1961 & GB 12 & $1: 24,800$ & $\begin{array}{l}\text { Well records show water-bearing material for } \\
\text { approximately } 90 \text { wells. Lithologic logs for } 17 \text { wells. } \\
\text { For Wallum Lake study area. Not on topographic base. } \\
\text { Generalized geologic sections. }\end{array}$ \\
\hline & 1974 & WRIR 18-74 & $1: 24,000$ & $\begin{array}{l}\text { Shows areas of till } \geq 40 \mathrm{ft} \text { thick and areas where till } \geq 40 \mathrm{ft} \\
\text { thick is reportedly underlain by stratified sand and } \\
\text { gravel. }\end{array}$ \\
\hline \multirow[t]{3}{*}{ Altitude of bedrock surface .......... } & 1953 & GB 6 & $1: 122,000$ & $\begin{array}{l}\text { Records of wells and test borings give land-surface } \\
\text { altitude and depth to bedrock. Not on topographic base. }\end{array}$ \\
\hline & 1961 & GWM 15 & $1: 24,000$ & $\begin{array}{l}\text { Approximate bedrock contours in stratified drift, } 50 \mathrm{ft} \\
\text { interval. Altitude of bedrock surface shown at well } \\
\text { locations. Bedrock outcrops shown. }\end{array}$ \\
\hline & 1961 & GB 12 & $1: 24,800$ & $\begin{array}{l}\text { Approximate hedrock contours in stratified drift, } 50 \mathrm{ft} \\
\text { interval. Not on topographic base. For Wallum Lake } \\
\text { study area. Well records give land-surface altitude and } \\
\text { depth to bedrock. }\end{array}$ \\
\hline \multirow[t]{2}{*}{ Water-table altitudes .......................... } & 1953 & GB 6 & $1: 122,000$ & $\begin{array}{l}\text { Well records give land-surface altitude and depth to } \\
\text { water. Not on topographic base. }\end{array}$ \\
\hline & 1961 & GWM 15 & $1: 24,000$ & $\begin{array}{l}\text { Water-table altitudes shown at well locations. Data on } \\
\text { wells collected chiefly in } 1960-61 .\end{array}$ \\
\hline \multirow[t]{2}{*}{ 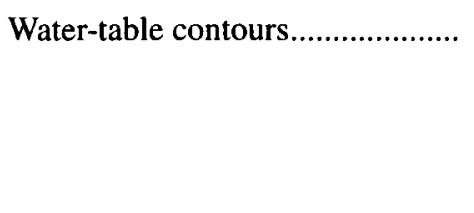 } & 1961 & GWM 15 & $1: 24,000$ & $\begin{array}{l}\text { Approximate water-table contours in stratified drift, } 20 \mathrm{ft} \\
\text { interval. Data on wells collected chiefly in } 1960-61 \text {. }\end{array}$ \\
\hline & 1961 & GB 12 & $1: 24,800$ & $\begin{array}{l}\text { Approximate water-table contours in stratified drift, } 40 \mathrm{ft} \\
\text { interval. Not on topographic base. For Wallum Lake } \\
\text { study area. }\end{array}$ \\
\hline 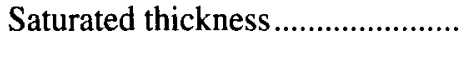 & 1974 & WRIR 18-74 & $1: 24,000$ & $\begin{array}{l}\text { Lines of equal saturated thickness, } 20 \mathrm{ft} \text { interval. For } \\
\text { Branch Basin. }\end{array}$ \\
\hline \multirow[t]{2}{*}{ 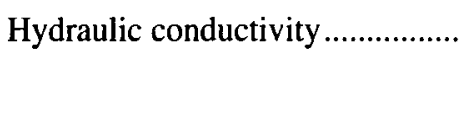 } & 1960 & HB 3 & $1: 148,000$ & Computed from aquifer test on 1 well. Shown in gal $/ \mathrm{d} / \mathrm{ft}^{2}$. \\
\hline & 1974 & WRIR 18-74 & $1: 24,000$ & $\begin{array}{l}\text { Estimated from lithologic logs and specific capacity data. } \\
\text { Shown in } \mathrm{ft} / \mathrm{d} \text {. For } 3 \text { wells. For Branch Basin. }\end{array}$ \\
\hline \multirow[t]{2}{*}{ 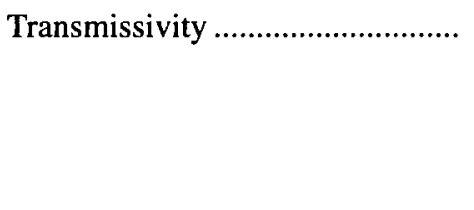 } & 1960 & HB 3 & $1: 148,000$ & $\begin{array}{l}\text { Computed from aquifer test on } 1 \text { well. Shown in } \\
\mathrm{gal} / \mathrm{d} / \mathrm{ft} \text {. }\end{array}$ \\
\hline & 1974 & WRIR 18-74 & $1: 24,000$ & $\begin{array}{l}\text { Estimated from lithologic logs and specific capacity data. } \\
\text { Shown in intervals of } 2,500 \text { and } 3,000 \mathrm{ft}^{2} / \mathrm{d} \text {. For } \\
\text { Branch Basin. }\end{array}$ \\
\hline \multirow[t]{2}{*}{ 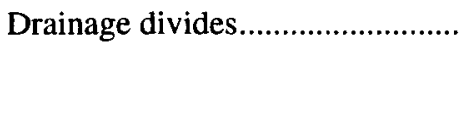 } & 1961 & GB 12 & $1: 24,800$ & $\begin{array}{l}\text { For subbasin of Quinebaug Basin. Not on topographic } \\
\text { base. }\end{array}$ \\
\hline & 1974 & WRIR 18-74 & $1: 24,000$ & For Branch Basin and subbasins. \\
\hline
\end{tabular}


Table 10. Geologic and hydrologic information for the Chepachet Quadrangle--Continued

\begin{tabular}{|c|c|c|c|c|}
\hline Information & Date & Publication & Scale & Remarks \\
\hline Drainage divides--Continued ....... & 1990 & WRIR 89-4164 & $1: 125,000$ & $\begin{array}{l}\text { For Branch and North Branch Pawtuxet Basins. Not on } \\
\text { topographic base. }\end{array}$ \\
\hline Ground-water reservoirs................. & 1974 & WRIR 18-74 & $1: 24,000$ & $\begin{array}{l}\text { Yields estimated for the Chepachet, Harrisville, and } \\
\text { Oakland areas of the Upper Branch ground-water } \\
\text { reservoir, using mathematical models. }\end{array}$ \\
\hline 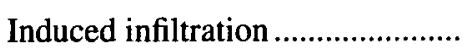 & 1974 & WRIR 18-74 & NA & Rates estimated for Branch Basin. \\
\hline \multirow[t]{3}{*}{ Ground-water quality ..................... } & 1953 & GB 6 & $1: 122,000$ & $\begin{array}{l}\text { Major inorganic constituents, physical properties. For } 5 \\
\text { wells. Not on topographic base. }\end{array}$ \\
\hline & 1961 & GB 12 & $1: 24,800$ & $\begin{array}{l}\text { Major inorganic constituents, physical properties. For } 5 \\
\text { wells. For Wallum Lake study area. }\end{array}$ \\
\hline & 1974 & WRIR 18-74 & $\begin{array}{l}1: 133,300 \\
1: 24,000\end{array}$ & $\begin{array}{l}\text { Major inorganic constituents, physical properties. For } 7 \\
\text { wells. For Branch Basin. }\end{array}$ \\
\hline
\end{tabular}


Table 11. Geologic and hydrologic information for the Clayville Quadrangle

\begin{tabular}{|c|c|c|c|c|}
\hline Information & Date & Publication & Scale & Remarks \\
\hline Surficial geology ............................. & 1962 & GWM 17 & $1: 24,000$ & Till and stratified-drift deposits. \\
\hline Bedrock geology .............................. & 1971 & В 1295 & $1: 125,000$ & Bedrock geologic map of Rhode Island. \\
\hline \multirow[t]{2}{*}{ Suhsurface materials .................. } & 1953 & GB 6 & $1: 122,000$ & $\begin{array}{l}\text { Records of wells and test borings show principal aquifer. } \\
\text { Not on topographic base. }\end{array}$ \\
\hline & 1961 & GB 11 & $\begin{array}{l}1: 38,300 \\
1: 55,500\end{array}$ & $\begin{array}{l}\text { Shows stratified-drift deposits } 0-50 \mathrm{ft} \text { thick for part of } \\
\text { the quadrangle. Not on topographic base. }\end{array}$ \\
\hline \multirow[t]{2}{*}{ Altitude of bedrock surface.......... } & 1953 & GB 6 & $1: 122,000$ & $\begin{array}{l}\text { Records of wells and test borings give land-surface } \\
\text { altitude and depth to bedrock. Not on topographic } \\
\text { base. }\end{array}$ \\
\hline & 1962 & GWM 17 & $1: 24,000$ & $\begin{array}{l}\text { Approximate bedrock contours in stratified drift, } 50 \mathrm{ft} \\
\text { interval. Altitude of bedrock surface shown at well } \\
\text { locations. Bedrock outcrops shown. }\end{array}$ \\
\hline \multirow[t]{2}{*}{ Water-table altitudes ........................ } & 1953 & GB 6 & $1: 122,000$ & $\begin{array}{l}\text { Well records give land-surface altitude and depth to } \\
\text { water. Not on topographic base. }\end{array}$ \\
\hline & 1962 & GWM 17 & $1: 24,000$ & $\begin{array}{l}\text { Water-table altitudes shown at well locations. Data on } \\
\text { wells collected chiefly in } 1961 .\end{array}$ \\
\hline Water-table contours...................... & 1962 & GWM 17 & $1: 24,000$ & $\begin{array}{l}\text { Approximate water-table contours in stratified drift, } 20 \mathrm{ft} \\
\text { interval. Data on wells collected chiefly in } 1961 \text {. }\end{array}$ \\
\hline 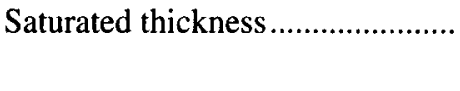 & 1974 & WRIR 18-74 & $1: 24,000$ & $\begin{array}{l}\text { Lines of equal saturated thickness, } 20 \mathrm{ft} \text { interval. For } \\
\text { Branch Basin. }\end{array}$ \\
\hline Transmissivity .................................. & 1974 & WRIR 18-74 & $1: 24,000$ & $\begin{array}{l}\text { Estimated from lithologic logs. Shown in intervals of } \\
2,500 \mathrm{ft}^{2} / \mathrm{d} \text {. For Branch Basin. }\end{array}$ \\
\hline \multirow[t]{3}{*}{ 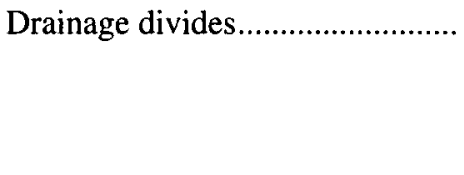 } & 1966 & HB 6 & $1: 24,000$ & For South Branch Pawtuxet Basin. \\
\hline & 1974 & WRIR 18-74 & $1: 24,000$ & For Branch Basin. \\
\hline & 1990 & WRIR 89-4164 & $1: 125,000$ & $\begin{array}{l}\text { For Branch and North Branch Pawtuxet Basins. Not on } \\
\text { topographic base. }\end{array}$ \\
\hline 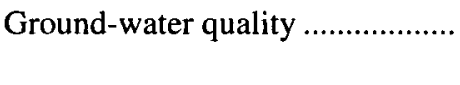 & 1953 & GB 6 & $1: 122,000$ & $\begin{array}{l}\text { Major inorganic constituents, physical properties. For } 1 \\
\text { well. Not on topographic base. }\end{array}$ \\
\hline
\end{tabular}


Table 12. Geologic and hydrologic information for the Coventry Center Quadrangle

\begin{tabular}{|c|c|c|c|c|}
\hline Information & Date & Publication & Scale & Remarks \\
\hline \multirow[t]{4}{*}{ 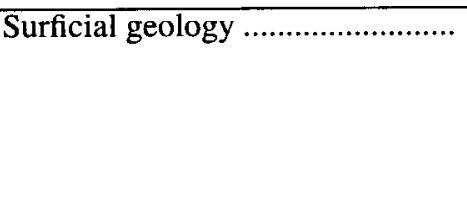 } & 1960 & GWM 8 & $1: 24,000$ & Till and stratified-drift deposits. \\
\hline & 1966 & HB 6 & $1: 24,000$ & $\begin{array}{l}\text { Till and stratified-drift deposits. For South Branch } \\
\text { Pawtuxet Basin. }\end{array}$ \\
\hline & 1989 & WISR 5 & $1: 24,000$ & Till and stratified-drift deposits. For Upper Wood Basin. \\
\hline & 1993 & WRIR 92-4119 & $1: 68,700$ & Till and stratified-drift deposits. For Upper Wood Basin. \\
\hline \multirow[t]{2}{*}{ 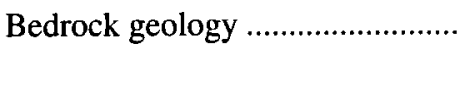 } & 1963 & B 1158-A & $1: 24,000$ & Detailed bedrock map. Geology mapped 1956-57. \\
\hline & 1971 & В 1295 & $1: 125,000$ & Bedrock geologic map of Rhude Island. \\
\hline \multirow[t]{4}{*}{ 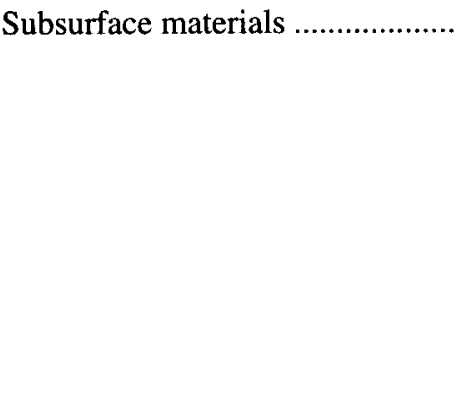 } & 1953 & GB 6 & $1: 122,000$ & $\begin{array}{l}\text { Records of wells and test borings show principal aquifer. } \\
\text { Not on topographic base. }\end{array}$ \\
\hline & 1961 & GB 11 & $\begin{array}{l}1: 55,500 \\
1: 61,400\end{array}$ & $\begin{array}{l}\text { Shows thickness of stratified-drift deposits in ranges of } \\
0-50,50-100 \text {, and } \geq 100 \mathrm{ft} \text {. Not on topographic base. }\end{array}$ \\
\hline & 1966 & HB 6 & $1: 24,000$ & $\begin{array}{l}\text { Records of wells and test borings show water-bearing } \\
\text { materials for many wells. For South Branch Pawtuxet } \\
\text { Basin. }\end{array}$ \\
\hline & 1989 & WISR 5 & $1: 24,000$ & $\begin{array}{l}\text { Records of wells and test holes show principal water- } \\
\text { bearing material. For approximately } 30 \text { wells. For } \\
\text { Upper Wood Basin. }\end{array}$ \\
\hline \multirow[t]{5}{*}{ Altitude of bedrock surface .......... } & 1953 & GB 6 & $1: 122,000$ & $\begin{array}{l}\text { Records of wells and test borings give land-surface } \\
\text { altitude and depth to bedrock. Not on topographic } \\
\text { base. }\end{array}$ \\
\hline & 1960 & GWM 8 & $1: 24,000$ & $\begin{array}{l}\text { Altitude of bedrock surface shown at well locations. } \\
\text { Bedrock outcrops in stratified drift shown. }\end{array}$ \\
\hline & 1966 & HB 6 & $1: 24,000$ & $\begin{array}{l}\text { Records of wells and test borings give land-surface } \\
\text { altitude and depth to bedrock. For many wells. For } \\
\text { South Branch Pawtuxet Basin. }\end{array}$ \\
\hline & 1989 & WISR 5 & $1: 24,000$ & $\begin{array}{l}\text { Records of wells and test holes give land-surface altitude } \\
\text { and depth to bedrock. For } 10 \text { wells. For Upper Wood } \\
\text { Basin. }\end{array}$ \\
\hline & 1993 & WRIR 92-4119 & $1: 54,100$ & $\begin{array}{l}\text { Bedrock contours, } 40 \mathrm{ft} \text { interval. For Upper Wood Basin. } \\
\text { Not on topographic base. }\end{array}$ \\
\hline \multirow[t]{4}{*}{ 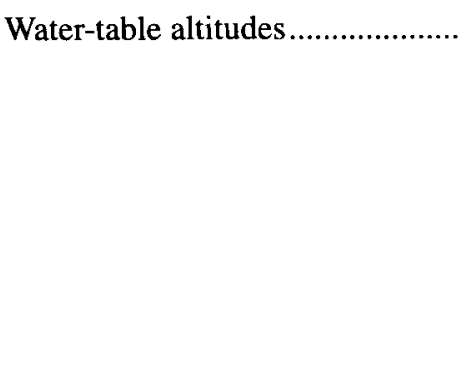 } & 1953 & GB 6 & $1: 122,000$ & $\begin{array}{l}\text { Well records give land-surface altitude and depth to } \\
\text { water. Not on topographic base. }\end{array}$ \\
\hline & 1960 & GWM 8 & $1: 24,000$ & Water-table altitudes shown at well locations. \\
\hline & 1966 & HB 6 & $1: 24,000$ & $\begin{array}{l}\text { Well records give land-surface altitude and depth to } \\
\text { water. For many wells. For South Branch Pawtuxet } \\
\text { Basin. }\end{array}$ \\
\hline & 1989 & WISR 5 & $1: 24,000$ & $\begin{array}{l}\text { Records of wells and test holes give land-surface altitude } \\
\text { and depth to water. For approximately } 20 \text { wells. For } \\
\text { Upper Wood Basin. }\end{array}$ \\
\hline \multirow[t]{2}{*}{ 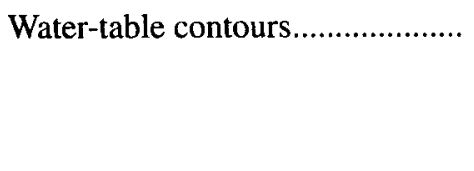 } & 1960 & GWM 8 & $1: 24,000$ & $\begin{array}{l}\text { Approximate contours in stratified drift, } 20 \mathrm{ft} \text { interval. } \\
\text { Data on wells collected chiefly in } 1953 \text {. }\end{array}$ \\
\hline & 1993 & WRIR 92-4119 & $1: 54,100$ & $\begin{array}{l}\text { Water-table contours in stratified drift, } 10 \mathrm{ft} \text { interval. For } \\
\text { Upper Wood Basin. Not on topographic base. }\end{array}$ \\
\hline \multirow[t]{2}{*}{ 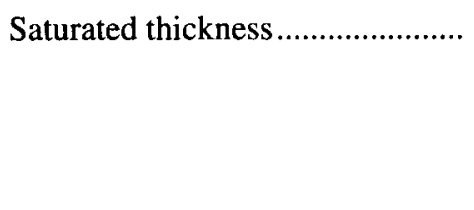 } & 1966 & HB 6 & $1: 24,000$ & $\begin{array}{l}\text { Can be estimated from water-table altitude and bedrock } \\
\text { altitude at well locations. For South Branch Pawtuxet } \\
\text { Basin. }\end{array}$ \\
\hline & 1993 & WRIR 92-4119 & $1: 54,100$ & $\begin{array}{l}\text { Lines of equal saturated thickness, } 20 \mathrm{ft} \text { interval. For } \\
\text { Upper Wood Basin. Not on topographic base. }\end{array}$ \\
\hline 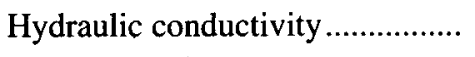 & 1992 & OFR 91-481 & NA & Values for till in $\mathrm{cm} / \mathrm{s}$ for 1 site. \\
\hline 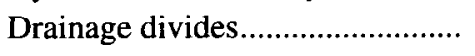 & 1966 & HB 6 & $1: 24,000$ & For South Branch Pawtuxet Basin. \\
\hline
\end{tabular}


Table 12. Geologic and hydrologic information for the Coventry Center Quadrangle--Continued

\begin{tabular}{|c|c|c|c|c|}
\hline Information & Date & Publication & Scale & Remarks \\
\hline \multirow{4}{*}{ Drainage divides--Continued ...... } & 1974 & WSP 2033 & $1: 48,000$ & For Lower Pawcatuck Basin. \\
\hline & 1989 & WISR 5 & $1: 24,000$ & For Upper Wood Basin. \\
\hline & 1990 & WRIR 89-4164 & $1: 125,000$ & $\begin{array}{l}\text { For North Branch and South Branch Pawtuxet Basins. } \\
\text { Not on topographic base. }\end{array}$ \\
\hline & 1993 & WRIR $92-4119$ & $1: 68,700$ & For Upper Wood Basin. \\
\hline Ground-water quality ....................... & 1966 & HB 6 & $1: 24,000$ & $\begin{array}{l}\text { Major inorganic constituents, physical properties. For } 4 \\
\text { wells. For South Branch Pawtuxet Basin. }\end{array}$ \\
\hline
\end{tabular}


Table 13. Geologic and hydrologic information for the Crompton Quadrangle

\begin{tabular}{|c|c|c|c|c|}
\hline Information & Date & Publication & Scale & Remarks \\
\hline \multirow[t]{6}{*}{ Surficial geology .............................. } & 1956 & GQ 94 & $1: 31,680$ & Detailed surficial map. Geology mapped 1951-52. \\
\hline & 1959 & GWM 3 & $1: 24,000$ & Till and stratified-drift deposits. \\
\hline & 1961 & WSP 1499-A & $1: 125,000$ & $\begin{array}{l}\text { Till and stratified-drift deposits. For northeastern Rhode } \\
\text { Island. }\end{array}$ \\
\hline & 1966 & HB 6 & $1: 24,000$ & $\begin{array}{l}\text { Till and stratified-drift deposits. For South Branch } \\
\text { Pawtuxet Basin. }\end{array}$ \\
\hline & 1966 & WSP 1821 & $1: 24,000$ & $\begin{array}{l}\text { Till and stratified-drift deposits. For small area of Upper } \\
\text { Pawcatuck Basin. }\end{array}$ \\
\hline & $\mathrm{U}$ & RAR 2 & $1: 24,000$ & $\begin{array}{l}\text { Till and stratified-drift deposits. For Hunt Basin. } \\
\text { Unpublished report, available at Rhode Island } \\
\text { Subdistrict Office, U.S. Geological Survey. }\end{array}$ \\
\hline \multirow[t]{2}{*}{ 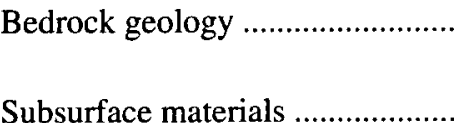 } & 1963 & B 1158-B & $1: 24,000$ & Detailed bedrock map. Geology mapped 1953-60. \\
\hline & 1971 & B 1295 & $1: 125,000$ & Bedrock geologic map of Rhode Island. \\
\hline \multirow[t]{4}{*}{ 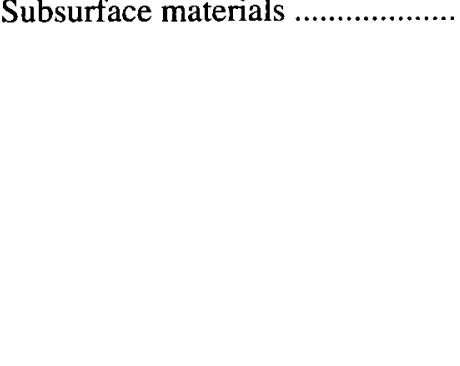 } & 1953 & GB 6 & $1: 122,000$ & $\begin{array}{l}\text { Records of wells and test borings show principal aquifer. } \\
\text { Lithologic logs for } 5 \text { wells. Not on topographic base. }\end{array}$ \\
\hline & 1961 & WSP 1499-A & $1: 125,000$ & $\begin{array}{l}\text { Shows stratified-drift deposits }<50 \mathrm{ft} \text { thick. For } \\
\text { northeastern Rhode Island. }\end{array}$ \\
\hline & 1961 & GB 11 & $\begin{array}{l}1: 55,500 \\
1: 62,400\end{array}$ & $\begin{array}{l}\text { Shows thickness of stratified-drift deposits in ranges of } \\
0-50,50-100 \text {, and } \geq 100 \mathrm{ft} \text {. Not on topographic base. }\end{array}$ \\
\hline & 1966 & HB 6 & $1: 24,000$ & $\begin{array}{l}\text { Records of wells and test borings show water-bearing } \\
\text { materials for many wells. Lithologic logs for many } \\
\text { wells. For South Branch Pawtuxet Basin. }\end{array}$ \\
\hline \multirow[t]{3}{*}{ Altitude of bedrock surface ........... } & 1953 & GB 6 & $1: 122,000$ & $\begin{array}{l}\text { Records of wells and test borings give land-surface } \\
\text { altitude and depth to bedrock. Not on topographic base. }\end{array}$ \\
\hline & 1959 & GWM 3 & $1: 24,000$ & $\begin{array}{l}\text { Approximate bedrock contours in stratified drift, } 50 \mathrm{ft} \\
\text { interval. Altitude of bedrock surface shown at well } \\
\text { locations. Bedrock outcrops in stratified drift shown. }\end{array}$ \\
\hline & 1966 & HB 6 & $1: 24,000$ & $\begin{array}{l}\text { Records of wells and test borings give land-surface } \\
\text { altitude and depth to bedrock. For many wells. For } \\
\text { South Branch Pawtuxet Basin. }\end{array}$ \\
\hline \multirow[t]{3}{*}{ 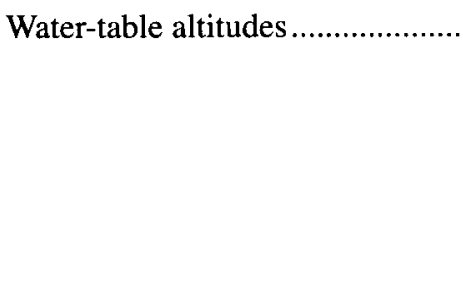 } & 1953 & GB 6 & $1: 122,000$ & $\begin{array}{l}\text { Well records give land-surface altitude and depth to } \\
\text { water. Not on topographic base. }\end{array}$ \\
\hline & 1959 & GWM 3 & $1: 24,000$ & $\begin{array}{l}\text { Water-table altitudes shown at well locations. Data on } \\
\text { wells collected chiefly in } 1953 \text {. }\end{array}$ \\
\hline & 1966 & HB 6 & $1: 24,000$ & $\begin{array}{l}\text { Well records give land-surface altitude and depth to } \\
\text { water. For many wells. For South Branch Pawtuxet } \\
\text { Basin. }\end{array}$ \\
\hline 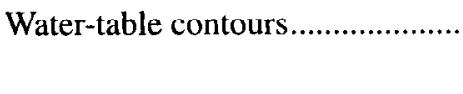 & 1959 & GWM 3 & $1: 24,000$ & $\begin{array}{l}\text { Approximate water-table contours in stratified drift, } 20 \mathrm{ft} \\
\text { interval. Data on wells collected chiefly in } 1953 \text {. }\end{array}$ \\
\hline 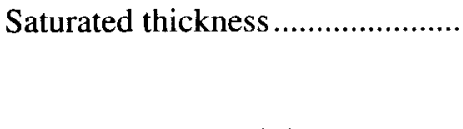 & 1966 & HB 6 & $1: 24,000$ & $\begin{array}{l}\text { Can be estimated from water-table altitude and bedrock } \\
\text { altitude at well locations. For South Branch Pawtuxet } \\
\text { Basin. }\end{array}$ \\
\hline Hydraulic conductivity .................. & 1966 & WSP 1821 & $1: 24,000$ & $\begin{array}{l}\text { Shows stratified drift with average range of } \\
20-100 \mathrm{gal} / \mathrm{d} / \mathrm{ft}^{2} \text {. For small area of Upper Pawcatuck } \\
\text { Basin. }\end{array}$ \\
\hline \multirow[t]{4}{*}{ Drainage divides..... } & 1963 & GB 13 & $1: 24,000$ & For small part of Upper Pawcatuck Basin. \\
\hline & 1966 & HB 6 & $1: 24,000$ & For South Branch Pawtuxet Basin. \\
\hline & 1966 & WSP 1821 & $1: 24,000$ & For small part of Upper Pawcatuck Basin. \\
\hline & 1968 & WSP 1775 & $1: 24,000$ & For Hunt and Maskerchugg Basins. \\
\hline
\end{tabular}


Table 13. Geologic and hydrologic information for the Crompton Quadrangle--Continued

\begin{tabular}{|c|c|c|c|c|}
\hline Information & Date & Publication & Scale & Remarks \\
\hline \multirow[t]{2}{*}{ Drainage divides--Continued ....... } & $\mathrm{U}$ & RAR 2 & $1: 24,000$ & $\begin{array}{l}\text { For Hunt and Maskerchugg basins. Unpublished report, } \\
\text { available at Rhode Island Subdistrict Office, U.S. } \\
\text { Geological Survey. }\end{array}$ \\
\hline & 1990 & WRIR 89-4164 & $1: 125,000$ & $\begin{array}{l}\text { For North Branch Pawtuxet, South Branch Pawtuxet, } \\
\text { Pawtuxet, Hunt, and Maskerchugg Basins. Not on } \\
\text { topographic base. }\end{array}$ \\
\hline 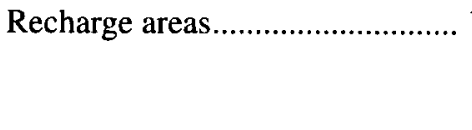 & $\mathrm{U}$ & RAR 2 & $1: 24,000$ & $\begin{array}{l}\text { For Hunt ground-water reservoir. Unpublished report, } \\
\text { available at Rhode Island Subdistrict Office, U.S. } \\
\text { Geological Survey. }\end{array}$ \\
\hline \multirow[t]{3}{*}{ Ground-water quality .... } & 1953 & GB 6 & $1: 122,000$ & $\begin{array}{l}\text { Major inorganic constituents, physical properties. For } 1 \\
\text { well. Not on topographic base. }\end{array}$ \\
\hline & 1961 & WSP 1499-A & $1: 125,000$ & $\begin{array}{l}\text { Major inorganic constituents, physical properties. For } 1 \\
\text { well. }\end{array}$ \\
\hline & 1966 & HB 6 & $1: 24,000$ & $\begin{array}{l}\text { Major inorganic constituents, physical properties. For } 12 \\
\text { wells. For South Branch Pawtuxet Basin. }\end{array}$ \\
\hline
\end{tabular}


Table 14. Geologic and hydrologic information for the East Greenwich Quadrangle

\begin{tabular}{|c|c|c|c|c|}
\hline Information & Date & Publication & Scale & Remarks \\
\hline \multirow[t]{5}{*}{ Surficial geology ................................ } & 1955 & GQ 62 & $1: 31,680$ & Detailed surficial map. Geology mapped 1949. \\
\hline & 1956 & GB 8 & $1: 31,680$ & Till and stratified-drift deposits. \\
\hline & 1961 & WSP 1499-A & $1: 125,000$ & $\begin{array}{l}\text { Till and stratified-drift deposits. For northeastern Rhode } \\
\text { Island. }\end{array}$ \\
\hline & 1966 & HB 6 & $1: 24,000$ & $\begin{array}{l}\text { Till and stratified-drift deposits. For South Branch Pawtuxet } \\
\text { Basin. }\end{array}$ \\
\hline & $\mathrm{U}$ & RAR 2 & $1: 24,000$ & $\begin{array}{l}\text { Till and stratified-drift deposits. For Hunt and Maskerchugg } \\
\text { Basins. Unpublished report, available at Rhode Island } \\
\text { Subdistrict Office, U.S. Geological Survey. }\end{array}$ \\
\hline \multirow[t]{4}{*}{ 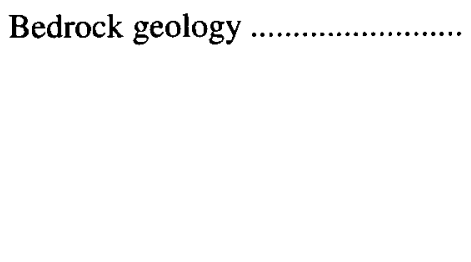 } & 1952 & GQ 17 & $1: 31,680$ & Detailed bedrock map. Geology mapped 1948-49. \\
\hline & 1956 & GB 8 & $1: 31,680$ & $\begin{array}{l}\text { Approximate contact between Pennsylvanian and pre- } \\
\text { Pennsylvanian bedrock shown. }\end{array}$ \\
\hline & 1961 & WSP 1499-A & $1: 362,100$ & $\begin{array}{l}\text { Generalized bedrock map shows Pennsylvanian/pre- } \\
\text { Pennsylvanian contact. }\end{array}$ \\
\hline & 1971 & B 1295 & $1: 125,000$ & Bedrock geologic map of Rhode Island. \\
\hline \multirow[t]{5}{*}{ Subsurface materials ..................... } & 1953 & GB 6 & $1: 122,000$ & $\begin{array}{l}\text { Records of wells and test borings show principal aquifer. } \\
\text { Lithologic logs for } 4 \text { wells. Not on topographic base. }\end{array}$ \\
\hline & 1956 & GB 8 & $1: 31,680$ & $\begin{array}{l}\text { Records of wells and test borings show water-bearing } \\
\text { materials for approximately } 300 \text { wells. Lithologic logs for } \\
64 \text { wells and test borings. Three generalized geologic } \\
\text { sections. }\end{array}$ \\
\hline & 1961 & WSP 1499-A & $1: 125,000$ & $\begin{array}{l}\text { Shows thickness of stratified-drift deposits in ranges of }<50 \text {, } \\
50-100 \text {, and }>100 \mathrm{ft} \text {. For northeastern Rhode Island. }\end{array}$ \\
\hline & 1961 & GB 11 & $\begin{array}{l}1: 55,500 \\
1: 62,400\end{array}$ & $\begin{array}{l}\text { Shows thickness of stratified-drift deposits in ranges of } 0-50 \text {, } \\
50-100 \text {, and } \geq 100 \mathrm{ft} \text {. Not on topographic base. }\end{array}$ \\
\hline & 1966 & HB 6 & $1: 24,000$ & $\begin{array}{l}\text { Records of wells and test borings show water-bearing } \\
\text { materials. For } 10 \text { wells. For South Branch Pawtuxet Basin. }\end{array}$ \\
\hline \multirow[t]{3}{*}{ Altitude of bedrock surface ........... } & 1953 & GB 6 & $1: 122,000$ & $\begin{array}{l}\text { Records of wells and test borings give land-surface altitude } \\
\text { and depth to bedrock. Not on topographic base. }\end{array}$ \\
\hline & 1956 & GB 8 & $1: 31,680$ & $\begin{array}{l}\text { Approximate bedrock contours in stratified drift, } 50 \mathrm{ft} \\
\text { interval. Bedrock altitudes shown at well locations. }\end{array}$ \\
\hline & 1966 & HB 6 & $1: 24,000$ & $\begin{array}{l}\text { Records of wells and test borings give land-surface altitude } \\
\text { and depth to bedrock. For } 9 \text { wells. For South Branch } \\
\text { Pawtuxet Basin. }\end{array}$ \\
\hline \multirow[t]{3}{*}{ 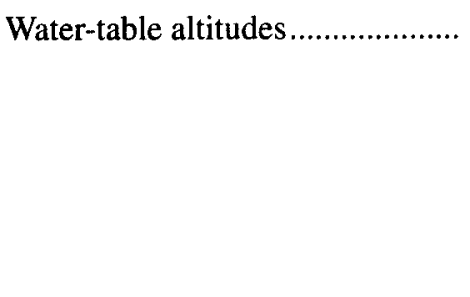 } & 1953 & GB 6 & $1: 122,000$ & $\begin{array}{l}\text { Well records give land-surface altitude and depth to water. } \\
\text { Not on topographic base. }\end{array}$ \\
\hline & 1956 & GB 8 & $1: 31,680$ & $\begin{array}{l}\text { Records of wells and test borings give land-surface altitude } \\
\text { and depth to water. For approximately } 200 \text { wells and test } \\
\text { borings. }\end{array}$ \\
\hline & 1966 & HB 6 & $1: 24,000$ & $\begin{array}{l}\text { Well records give land-surface altitude and depth to water. } \\
\text { For } 7 \text { wells. For South Branch Pawtuxet Basin. }\end{array}$ \\
\hline \multirow{3}{*}{ 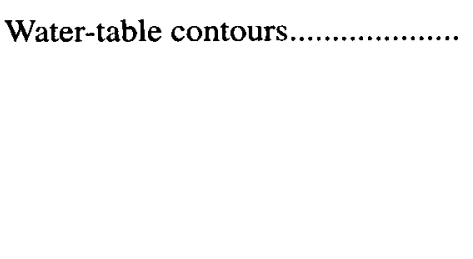 } & 1956 & GB 8 & $1: 79,000$ & For area north of Greenwich Bay. Not on topographic base. \\
\hline & 1968 & WSP 1775 & $1: 24,000$ & $\begin{array}{l}\text { Water-table contours, } 10 \text { and } 20 \mathrm{ft} \text { intervals. For Hunt and } \\
\text { Maskerchugg Basins and coastal areas. }\end{array}$ \\
\hline & $\mathrm{U}$ & RAR 2 & $1: 24,000$ & $\begin{array}{l}\text { Water-table contours, } 10 \mathrm{ft} \text { interval. For Hunt and Masker- } \\
\text { chugg Basins. Unpublished report, available at Rhode } \\
\text { Island Subdistrict Office, U.S. Geological Survey }\end{array}$ \\
\hline 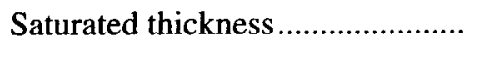 & 1956 & GB 8 & $1: 31,680$ & $\begin{array}{l}\text { Can be estimated from depth to bedrock and depth to water at } \\
\text { well locations. }\end{array}$ \\
\hline
\end{tabular}


Table 14. Geologic and hydrologic information for the East Greenwich Quadrangle--Continued

\begin{tabular}{|c|c|c|c|c|}
\hline Information & Date & Publication & Scale & Remarks \\
\hline \multirow[t]{2}{*}{ Saturated thickness--Continued... } & 1966 & HB 6 & $1: 24,000$ & $\begin{array}{l}\text { Can be estimated from water-table altitude and bedrock } \\
\text { altitude at well lociations. For South Branch Pawtuxet } \\
\text { Basin. }\end{array}$ \\
\hline & 1968 & WSP 1775 & $1: 24,000$ & $\begin{array}{l}\text { Lines of equal saturated thickness, } 20 \mathrm{ft} \text { interval. For the } \\
\text { Hunt and Maskerchugg Basins and coastal areas. }\end{array}$ \\
\hline Transmissivity ................................ & 1968 & WSP 1775 & $1: 24,000$ & $\begin{array}{l}\text { Lines of equal transmissivity, } 20,000 \text { and } 100,000 \mathrm{gal} / \mathrm{d} / \mathrm{ft} \\
\text { intervals. For the Hunt and Maskerchugg Basins and } \\
\text { coastal areas. }\end{array}$ \\
\hline \multirow[t]{4}{*}{ Drainage divides............................ } & 1966 & HB 6 & $1: 24,000$ & For South Branch Pawtuxet Basin. \\
\hline & 1968 & WSP 1775 & $1: 24,000$ & For Maskcrchugg Basin. \\
\hline & $\mathrm{U}$ & RAR 2 & $1: 24,000$ & $\begin{array}{l}\text { For Hunt and Maskerchugg Basins. Unpublished report, } \\
\text { available at Rhode Island Subdistrict Office, U.S. } \\
\text { Geological Survey. }\end{array}$ \\
\hline & 1990 & $\begin{array}{l}\text { WRIR 89- } \\
4164\end{array}$ & $1: 125,000$ & $\begin{array}{l}\text { For Pawtuxet, Buckeye, Maskerchugg, and Hunt Basins. Not } \\
\text { on topographic base. }\end{array}$ \\
\hline 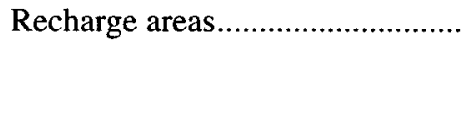 & $\mathrm{U}$ & RAR 2 & $1: 24,000$ & $\begin{array}{l}\text { For Hunt ground-water reservoir. Unpublished report, } \\
\text { available at Rhode Island Subdistrict Office, U.S. } \\
\text { Geological Survey. }\end{array}$ \\
\hline \multirow[t]{2}{*}{ Ground-water reservoirs............... } & 1968 & WSP 1775 & $1: 24,000$ & $\begin{array}{l}\text { Mathematical model used to evaluate yield for Hunt ground- } \\
\text { water reservoir. }\end{array}$ \\
\hline & $\mathrm{U}$ & RAR 2 & $1: 24,000$ & $\begin{array}{l}\text { Shows Hunt ground-water reservoir. Unpublished report, } \\
\text { available at Rhode Island Subdistrict Office, U.S. } \\
\text { Geological Survey. }\end{array}$ \\
\hline Induced infiltration & 1968 & WSP 1775 & NA & $\begin{array}{l}\text { Potential streambed infiltration rates estimated for the Hunt } \\
\text { River. }\end{array}$ \\
\hline \multirow[t]{3}{*}{ Ground-water quality ................... } & 1953 & GB 6 & $1: 122,000$ & $\begin{array}{l}\text { Major inorganic constituents, physical properties. For } 6 \\
\text { wells. Not on topographic base. }\end{array}$ \\
\hline & 1956 & GB 8 & $1: 31,680$ & $\begin{array}{l}\text { Major inorganic constituents, physical properties. For } 17 \\
\text { wells. }\end{array}$ \\
\hline & 1961 & WSP 1499-A & $1: 125,000$ & $\begin{array}{l}\text { Major inorganic constituents, physical properties. For } 3 \\
\text { wells. }\end{array}$ \\
\hline
\end{tabular}


Table 15. Geologic and hydrologic information for the East Killingly Quadrangle

\begin{tabular}{|c|c|c|c|c|}
\hline Information & Date & Publication & Scale & Remarks \\
\hline 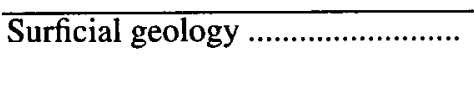 & 1962 & GWM 18 & $1: 24,000$ & $\begin{array}{l}\text { Till and stratified-drift deposits. For Rhode Island part of } \\
\text { quadrangle. }\end{array}$ \\
\hline \multirow[t]{2}{*}{ 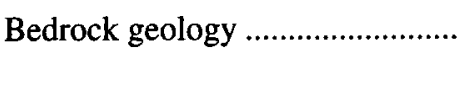 } & 1983 & GQ 1571 & $1: 24,000$ & Detailed bedrock map. Geology mapped 1965-67. \\
\hline & 1971 & B 1295 & $1: 125,000$ & Bedrock geologic map of Rhode Island. \\
\hline Subsurface materials .................... & 1953 & GB 6 & $1: 122,000$ & $\begin{array}{l}\text { Records of wells and test borings show principal aquifer. } \\
\text { Not on topographic base. }\end{array}$ \\
\hline \multirow[t]{2}{*}{ Altitude of bedrock surface } & 1953 & GB 6 & $1: 122,000$ & $\begin{array}{l}\text { Records of wells and test borings give land-surface } \\
\text { altitude and depth to bedrock. Not on topographic base. }\end{array}$ \\
\hline & 1962 & GWM 18 & $1: 24,000$ & $\begin{array}{l}\text { Approximate contours in stratified drift, } 100 \mathrm{ft} \text { interval. } \\
\text { Altitude of bedrock surface shown at well locations. }\end{array}$ \\
\hline \multirow[t]{2}{*}{ 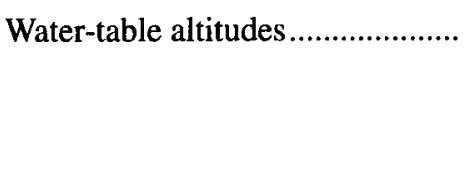 } & 1953 & GB 6 & $1: 122,000$ & $\begin{array}{l}\text { Well records give land-surface altitude and depth to water. } \\
\text { Not on topographic base. }\end{array}$ \\
\hline & 1962 & GWM 18 & $1: 24,000$ & $\begin{array}{l}\text { Water-table altitude shown at well locations. Data on } \\
\text { wells collected chiefly in } 1961 .\end{array}$ \\
\hline 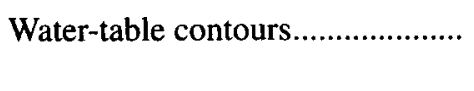 & 1962 & GWM 18 & $1: 24,000$ & $\begin{array}{l}\text { Approximate contours in stratified drift, } 40 \mathrm{ft} \text { interval. } \\
\text { Data on wells collected chiefly in } 1961 \text {. }\end{array}$ \\
\hline Drainage divides.............................. & 1990 & WRIR 89-4164 & $1: 125,000$ & $\begin{array}{l}\text { For North Branch Pawtuxet Basin. Not on topographic } \\
\text { base. }\end{array}$ \\
\hline
\end{tabular}


Table 16. Geologic and hydrologic information for the East Providence Quadrangle

\begin{tabular}{|c|c|c|c|c|}
\hline Information & Date & Publication & Scale & Remarks \\
\hline \multirow[t]{4}{*}{ Surficial geology ............................. } & 1950 & SC 3 & $1: 33,500$ & $\begin{array}{l}\text { Till and stratified-drift deposits. For towns of Barrington } \\
\text { and Warren. }\end{array}$ \\
\hline & 1959 & GWM 4 & $1: 24,000$ & Till and stratified-drift deposits. \\
\hline & 1961 & WSP 1499-A & $1: 125,000$ & $\begin{array}{l}\text { Till and stratified-drift deposits. For northeastern Rhode } \\
\text { Island. }\end{array}$ \\
\hline & 1974 & HB 7 & $1: 24,000$ & $\begin{array}{l}\text { Till and stratified-drift deposits. For Tenmile Basin and } \\
\text { coastal areas. }\end{array}$ \\
\hline \multirow[t]{2}{*}{ Bedrock geology ........... } & 1971 & B 1295 & $1: 125,000$ & Bedrock geologic map of Rhode Island. \\
\hline & 1977 & OFR $77-816$ & $1: 31,250$ & $\begin{array}{l}\text { Handwritten information on a topographic base. Plates on } \\
\text { file at U.S. Geological Survey National Center Library, } \\
\text { Reston, Va. }\end{array}$ \\
\hline \multirow[t]{7}{*}{ Subsurface materials ....................... } & 1950 & SC 3 & $1: 33,500$ & $\begin{array}{l}\text { Well records show materials penetrated. For } 17 \text { wells. For } \\
\text { towns of Barrington and Warren. }\end{array}$ \\
\hline & 1953 & GB 6 & $1: 122,000$ & $\begin{array}{l}\text { Records of wclls and test borings show principal aquifer. } \\
\text { Lithologic logs for } 13 \text { wells. Not on topographic base. }\end{array}$ \\
\hline & 1960 & HB 3 & $1: 148,000$ & Lithologic $\log$ for 1 well. \\
\hline & 1961 & WSP 1499-A & $1: 125,000$ & $\begin{array}{l}\text { Shows thickness of stratified-drift deposits in ranges of } \\
<50,50-100 \text {, and }>100 \mathrm{ft} \text {. For northeastern Rhode } \\
\text { Island. }\end{array}$ \\
\hline & 1961 & GB 11 & $1: 62,400$ & $\begin{array}{l}\text { Shows thickness of stratified-drift deposits in ranges of } \\
0-50,50-100 \text {, and } \geq 100 \mathrm{ft} \text {. For Rhode Island part of } \\
\text { quadrangle. Not on topographic base. }\end{array}$ \\
\hline & 1974 & HB 7 & $1: 24,000$ & $\begin{array}{l}\text { Records of wells and test holes show water-bearing } \\
\text { materials for } 50 \text { wells. Lithologic logs for } 109 \text { wells. }\end{array}$ \\
\hline & 1974 & WRIR 4-74 & $1: 24,000$ & $\begin{array}{l}\text { Shows areas where substantial part of saturated zone is } \\
\text { composed of silt and clay. }\end{array}$ \\
\hline \multirow[t]{4}{*}{ Altitude of bedrock surface........... } & 1950 & $\mathrm{SC} 3$ & $1: 33,500$ & $\begin{array}{l}\text { Well records give approximate altitude of bedrock } \\
\text { surface. For } 3 \text { wells. For town of Barrington. }\end{array}$ \\
\hline & 1953 & GB 6 & $1: 122,000$ & $\begin{array}{l}\text { Records of wells and test borings give land-surface } \\
\text { altitude and depth to bedrock. Not on topographic base. }\end{array}$ \\
\hline & 1959 & GWM 4 & $1: 24,000$ & $\begin{array}{l}\text { Approximate bedrock contours in stratified drift, } 50 \mathrm{ft} \\
\text { interval. Altitude of bedrock surface shown at well } \\
\text { locations. Bedrock outcrops in stratified drift shown. }\end{array}$ \\
\hline & 1974 & HB 7 & $1: 24,000$ & $\begin{array}{l}\text { Records of wells and test holes give land-surface altitude } \\
\text { and depth to bedrock for } 39 \text { wells. For Tenmile Basin } \\
\text { and coastal areas. }\end{array}$ \\
\hline \multirow[t]{4}{*}{ 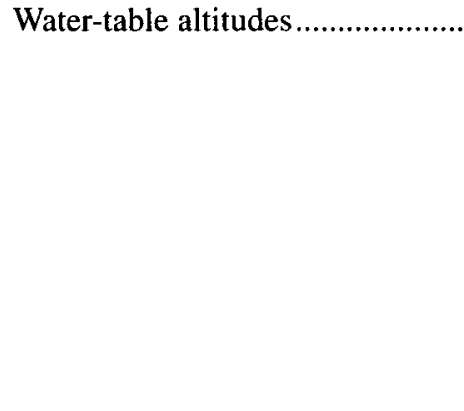 } & 1950 & $\mathrm{SC} 3$ & $1: 33,500$ & $\begin{array}{l}\text { Well records give approximate land-surface altitude and } \\
\text { depth to water. For } 2 \text { wells. For towns of Barrington } \\
\text { and Warren. }\end{array}$ \\
\hline & 1953 & GB 6 & $1: 122,000$ & $\begin{array}{l}\text { Well records give land-surface altitude and depth to water. } \\
\text { Not on topographic base. }\end{array}$ \\
\hline & 1959 & GWM 4 & $1: 24,000$ & $\begin{array}{l}\text { Water-table altitudes shown at well locations. Data on } \\
\text { wells collected chiefly in } 1952 .\end{array}$ \\
\hline & 1974 & HB 7 & $1: 24,000$ & $\begin{array}{l}\text { Records of wells and test holes give land-surface altitude } \\
\text { and depth to water for } 81 \text { wells. For Tenmile Basin and } \\
\text { coastal areas. }\end{array}$ \\
\hline Water-table contours......................... & 1959 & GWM 4 & $1: 24,000$ & $\begin{array}{l}\text { Approximate water-table contours in stratified drift, } 10 \\
\text { and } 20 \mathrm{ft} \text { intervals. Data on wells collected chiefly in } \\
1952 .\end{array}$ \\
\hline Saturated thickness & 1974 & WRIR 4-74 & $1: 24,000$ & $\begin{array}{l}\text { Lines of equal saturated thickness; } 10,30 \text {, and } 40 \mathrm{ft} \\
\text { intervals. For Tenmile Basin and coastal areas. }\end{array}$ \\
\hline
\end{tabular}


Table 16. Geologic and hydrologic information for the East Providence Quadrangle--Continued

\begin{tabular}{|c|c|c|c|c|}
\hline Information & Date & Publication & Scale & Remarks \\
\hline Hydraulic conductivity .................... & 1960 & HB 3 & $1: 148,000$ & Computed from aquifer test on 1 well. Shown in $\mathrm{gal} / \mathrm{d} / \mathrm{ft}^{2}$. \\
\hline \multirow{2}{*}{ 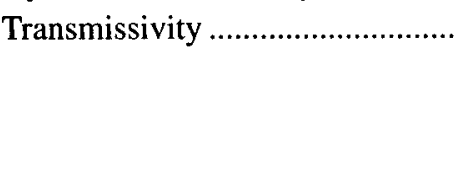 } & 1960 & HB 3 & $1: 148,000$ & Computed from aquifer test on 1 well. Shown in $\mathrm{gal} / \mathrm{d} / \mathrm{ft}$. \\
\hline & 1974 & WRIR 4-74 & $1: 24,000$ & $\begin{array}{l}\text { Estimated from lithologic logs, aquifer tests, or specific } \\
\text { capacity data. Shown in intervals of } 4,000 \mathrm{ft}^{2} / \mathrm{d} \\
(30,000 \mathrm{gal} / \mathrm{d} / \mathrm{ft}) \text {. For Tenmile Basin and coastal areas. }\end{array}$ \\
\hline \multirow{2}{*}{ Drainage divides.................................. } & 1974 & WRIR 4-74 & $1: 24,000$ & For Tenmile Basin. \\
\hline & 1990 & WRIR 89-4164 & $1: 125,000$ & $\begin{array}{l}\text { For Tenmile and Runnins Basins. Not on topographic } \\
\text { base. }\end{array}$ \\
\hline Ground-water reservoirs.................. & 1974 & WRIR 4-74 & $1: 24,000$ & $\begin{array}{l}\text { Yield estimated from mathematical model for Tenmile } \\
\text { ground-water reservoir. }\end{array}$ \\
\hline \multirow[t]{4}{*}{ 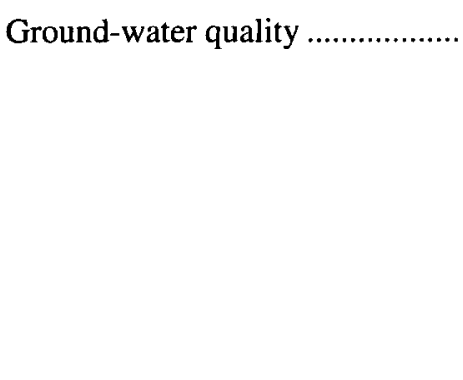 } & 1953 & GB 6 & $1: 122,000$ & $\begin{array}{l}\text { Major inorganic constituents, physical properties. For } 5 \\
\text { wells. Not on topographic base. }\end{array}$ \\
\hline & 1961 & WSP 1499-A & $1: 125,000$ & $\begin{array}{l}\text { Major inorganic constituents, physical properties. For } 1 \\
\text { well. }\end{array}$ \\
\hline & 1974 & WRIR 4-74 & various & $\begin{array}{l}\text { Major inorganic constituents for } 1 \text { well. Dissolved solids, } \\
\text { iron, and manganese trends for } 1 \text { well. For Tenmile } \\
\text { Basin. }\end{array}$ \\
\hline & 1974 & HB 7 & $1: 24,000$ & $\begin{array}{l}\text { Major inorganic constituents, physical properties. For } 14 \\
\text { wells. For Tenmile Basin and coastal areas. }\end{array}$ \\
\hline
\end{tabular}


Table 17. Geologic and hydrologic information for the Fall River Quadrangle

\begin{tabular}{|c|c|c|c|c|}
\hline Information & Date & Publication & Scale & Remarks \\
\hline \multirow[t]{4}{*}{ 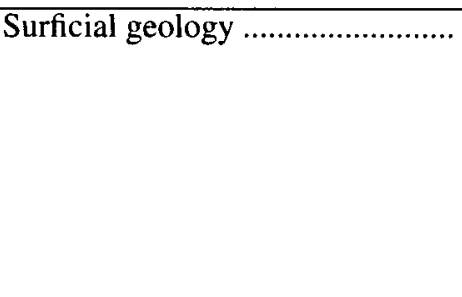 } & 1950 & $\mathrm{SC} 3$ & $1: 33,500$ & $\begin{array}{l}\text { Till and stratified-drift deposits. For towns of Warren and } \\
\text { Bristol. }\end{array}$ \\
\hline & 1955 & GQ 70 & $1: 31,680$ & $\begin{array}{l}\text { Detailed surficial map for small area of quadrangle. } \\
\text { Geology mapped in } 1950 .\end{array}$ \\
\hline & 1960 & GWM 7 & $1: 24,000$ & Till and stratified-drift deposits. \\
\hline & 1961 & WSP $1499-\Lambda$ & $1: 125,000$ & $\begin{array}{l}\text { Till and stratified-drift deposits. For northcastern Rhode } \\
\text { Island. }\end{array}$ \\
\hline \multirow[t]{4}{*}{ 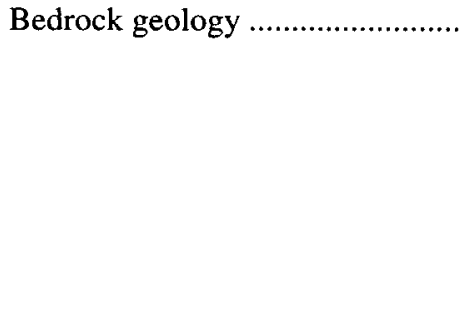 } & 1954 & GQ 42 & $1: 31,680$ & $\begin{array}{l}\text { Detailed bedrock map for small arca of quadrangle. } \\
\text { Geology mapped in } 1952 \text {. }\end{array}$ \\
\hline & 1961 & WSP 1499-A & $1: 362,100$ & $\begin{array}{l}\text { Generalized bedrock map shows Pennsylvanian/pre- } \\
\text { Pennsylvanian contact. For northeastern Rhode Island. }\end{array}$ \\
\hline & 1971 & В 1295 & $1: 125,000$ & Bedrock geologic map of Rhode Island. \\
\hline & 1977 & OFR 77-816 & $1: 31,250$ & $\begin{array}{l}\text { Handwritten information on a topographic base. Plates } \\
\text { on file at U.S. Geological Survey National Center } \\
\text { Library, Reston, Va. }\end{array}$ \\
\hline \multirow[t]{3}{*}{ 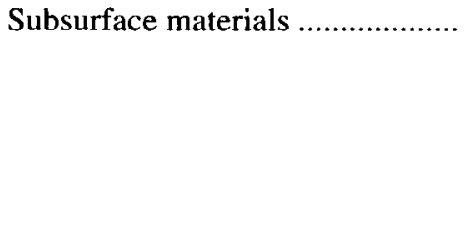 } & 1950 & SC 3 & $1: 33,500$ & $\begin{array}{l}\text { Well records show materials penetrated. For } 19 \text { wells. } \\
\text { For towns of Warren and Bristol. }\end{array}$ \\
\hline & 1953 & GB 6 & $1: 122,000$ & $\begin{array}{l}\text { Records of wells and test borings show principal aquifer. } \\
\text { Lithologic logs for } 2 \text { wells. Not on topographic base. }\end{array}$ \\
\hline & 1961 & WSP 1499-A & $1: 125,000$ & $\begin{array}{l}\text { Shows stratified-drift deposits }<50 \mathrm{ft} \text { thick. For } \\
\text { northeastern Rhode Island. }\end{array}$ \\
\hline \multirow[t]{3}{*}{ Altitude of bedrock surface.......... } & 1950 & SC 3 & $1: 33,500$ & $\begin{array}{l}\text { Well records give approximate altitude of bedrock } \\
\text { surface. For } 3 \text { wells. For towns of Warren and Bristol. }\end{array}$ \\
\hline & 1953 & GB 6 & $1: 122,000$ & $\begin{array}{l}\text { Records of wells and test borings give land-surface } \\
\text { altitude and depth to bedrock. Not on topographic } \\
\text { base. }\end{array}$ \\
\hline & 1960 & GWM 7 & $1: 24,000$ & $\begin{array}{l}\text { Approximate bedrock contours in stratified drift, } 100 \mathrm{ft} \\
\text { interval. Altitude of bedrock surface shown at well } \\
\text { locations. Bedrock outcrops in stratified drift shown. }\end{array}$ \\
\hline \multirow[t]{3}{*}{ Water-table altitudes............................ } & 1950 & SC 3 & $1: 33,500$ & $\begin{array}{l}\text { Well records give approximate land-surface altitude and } \\
\text { depth to water. For } 6 \text { wells. For towns of Warren and } \\
\text { Bristol. }\end{array}$ \\
\hline & 1953 & GB 6 & $1: 122,000$ & $\begin{array}{l}\text { Well records give land-surface altitude and depth to } \\
\text { water. Not on topographic base. }\end{array}$ \\
\hline & 1960 & GWM 7 & $1: 24,000$ & $\begin{array}{l}\text { Water-table altitudes shown at well locations. Data on } \\
\text { wells collected chiefly in } 1948 \text { and } 1952 .\end{array}$ \\
\hline 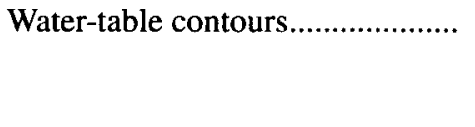 & 1960 & GWM 7 & $1: 24,000$ & $\begin{array}{l}\text { Approximate water-table contours in stratified drift, } 10 \mathrm{ft} \\
\text { interval. Data on wells collected chiefly in } 1948 \text { and } \\
1952 \text {. }\end{array}$ \\
\hline 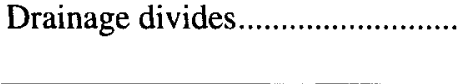 & 1990 & WRIR 89-4164 & $1: 125,000$ & $\begin{array}{l}\text { For Quequechan and Adamsville Basins. Not on } \\
\text { topographic base. }\end{array}$ \\
\hline
\end{tabular}


Table 18. Geologic and hydrologic information for the Franklin Quadrangle

\begin{tabular}{|c|c|c|c|c|}
\hline Information & Date & Publication & Scale & Remarks \\
\hline \multirow[t]{5}{*}{ Surficial geology ................................. } & 1950 & GB 5 & $1: 15,700$ & $\begin{array}{l}\text { Till and stratified-drift deposits. For the city of } \\
\text { Woonsocket. }\end{array}$ \\
\hline & 1961 & WSP 1499-A & $1: 125,000$ & $\begin{array}{l}\text { Till and stratified-drift deposits. For northeastern Rhode } \\
\text { Island. }\end{array}$ \\
\hline & 1962 & GWM 19 & $1: 24,000$ & $\begin{array}{l}\text { Till and stratified-drift deposits. For Rhode Island part } \\
\text { of quadrangle. }\end{array}$ \\
\hline & 1974 & HB 7 & $1: 24,000$ & $\begin{array}{l}\text { Till and stratified-drift deposits. For Blackstone and } \\
\text { Abbott Run Basins. }\end{array}$ \\
\hline & 1985 & RAR 1 & $1: 24,000$ & Till and stratified-drift deposits. For Blackstone Basin. \\
\hline \multirow[t]{4}{*}{ 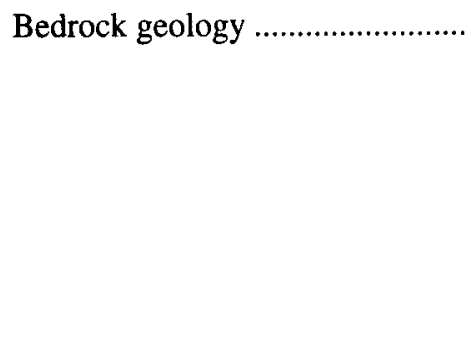 } & 1950 & GB 5 & $1: 15,700$ & Detailed bedrock map. For the city of Woonsocket. \\
\hline & 1961 & WSP 1499-A & $1: 362,100$ & $\begin{array}{l}\text { Generalized bedrock map shows Pennsylvanian/pre- } \\
\text { Pennsylvanian contact. For northeastern Rhode } \\
\text { Island. }\end{array}$ \\
\hline & 1971 & B 1295 & $1: 125,000$ & Bedrock geologic map of Rhode Island. \\
\hline & 1977 & OFR 77-816 & $1: 31,250$ & $\begin{array}{l}\text { Handwritten information on a topographic base. Plates } \\
\text { on file at U.S. Geological Survey National Center } \\
\text { Library, Reston, Va. }\end{array}$ \\
\hline \multirow[t]{7}{*}{ Subsurface materials ...................... } & 1950 & GB 5 & $1: 15,700$ & $\begin{array}{l}\text { Well records show materials penetrated for approxi- } \\
\text { mately } 20 \text { wells. Lithologic log for } 1 \text { well. For the } \\
\text { city of Woonsocket. }\end{array}$ \\
\hline & 1953 & GB 6 & $1: 122,000$ & $\begin{array}{l}\text { Records of wells and test borings show principal } \\
\text { aquifer. Not on topographic base. }\end{array}$ \\
\hline & 1960 & HB 3 & $1: 148,000$ & Lithologic $\log$ for 1 well. \\
\hline & 1961 & WSP 1499-A & $1: 125,000$ & $\begin{array}{l}\text { Shows thickness of stratified-drift deposits in ranges of } \\
<50 \text { and } 50-100 \mathrm{ft} \text {. For northeastern Rhode Island. }\end{array}$ \\
\hline & 1961 & GB 11 & $1: 62,400$ & $\begin{array}{l}\text { Shows thickness of stratified-drift deposits in ranges } \\
\text { of } 0-50 \text { and } 50-100 \mathrm{ft} \text {. For Rhode Island part of quad- } \\
\text { rangle. Not on topographic basc. }\end{array}$ \\
\hline & 1974 & HB 7 & $1: 24,000$ & $\begin{array}{l}\text { Records of wells and test holes show water-bearing } \\
\text { materials for } 11 \text { wells. Lithologic logs for } 10 \text { wells. } \\
\text { For Blackstone and Abbott Run Basins. }\end{array}$ \\
\hline & 1974 & WRIR 4-74 & $1: 24,000$ & $\begin{array}{l}\text { Shows areas where substantial part of saturated zone is } \\
\text { composed of silt and clay. }\end{array}$ \\
\hline \multirow[t]{4}{*}{ Altitude of bedrock surface ........... } & 1950 & GB 5 & $1: 15,700$ & $\begin{array}{l}\text { Well records give land-surface altitude and depth to } \\
\text { bedrock for approximately } 20 \text { wells. Bedrock out- } \\
\text { crops shown. For the city of Woonsocket. }\end{array}$ \\
\hline & 1953 & GB 6 & $1: 122,000$ & $\begin{array}{l}\text { Records of wells and test borings give land-surface } \\
\text { altitude and depth to bedrock. Not on topographic } \\
\text { base. }\end{array}$ \\
\hline & 1962 & GWM 19 & $1: 24,000$ & $\begin{array}{l}\text { Approximate bedrock contours in stratified drift, } 100 \mathrm{ft} \\
\text { interval. Altitude of bedrock surface shown at well } \\
\text { locations. Bedrock outcrops in stratified drift shown. }\end{array}$ \\
\hline & 1974 & HB 7 & $1: 24,000$ & $\begin{array}{l}\text { Records of wells and test holes give land-surface } \\
\text { altitude and depth to bedrock for } 11 \text { wells. For } \\
\text { Blackstone and Abbott Run Basins. }\end{array}$ \\
\hline \multirow[t]{2}{*}{ 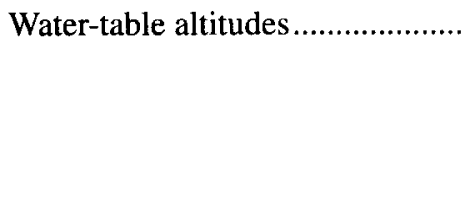 } & 1950 & GB 5 & $1: 15,700$ & $\begin{array}{l}\text { Well records give land-surface altitude and depth to } \\
\text { water for approximately } 20 \text { wells. For the city of } \\
\text { Woonsocket. }\end{array}$ \\
\hline & 1953 & GB 6 & $1: 122,000$ & $\begin{array}{l}\text { Well records give land-surface altitude and depth to } \\
\text { water. Not on topographic base. }\end{array}$ \\
\hline
\end{tabular}


Table 18. Geologic and hydrologic information for the Franklin Quadrangle--Continued

\begin{tabular}{|c|c|c|c|c|}
\hline Information & Date & Publication & Scale & Remarks \\
\hline \multicolumn{5}{|l|}{ Water-table altitudes-- } \\
\hline \multirow[t]{2}{*}{ Continued .................... } & 1962 & GWM 19 & $1: 24,000$ & $\begin{array}{l}\text { Water-table altitudes shown at well locations. Data on } \\
\text { wells collected chiefly in } 1961 \text {. }\end{array}$ \\
\hline & 1974 & HB 7 & $1: 24,000$ & $\begin{array}{l}\text { Records of wells and test holes give land-surface } \\
\text { altitude and depth to water for } 20 \text { wells. For } \\
\text { Blackstone and Abbott Run Basins. }\end{array}$ \\
\hline \multirow[t]{2}{*}{ 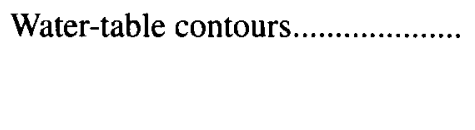 } & 1962 & GWM 19 & $1: 24,000$ & $\begin{array}{l}\text { Contours in stratified drift, } 20 \mathrm{ft} \text { interval. Data on wells } \\
\text { collected chiefly in } 1961 .\end{array}$ \\
\hline & 1985 & RAR 1 & $1: 24,000$ & Contour interval $10 \mathrm{ft}$. For Blackstone Basin. \\
\hline Saturated thickness .......................... & 1974 & WRIR 4-74 & $1: 24,000$ & $\begin{array}{l}\text { Lines of equal saturated thickness; } 10,30 \text {, and } 40 \mathrm{ft} \\
\text { intervals. For Blackstone and Abbott Run Basins. }\end{array}$ \\
\hline Hydraulic conductivity .................. & 1960 & HB 3 & $1: 148,000$ & $\begin{array}{l}\text { Computed from aquifer test on } 1 \text { well. Shown in } \\
\mathrm{gal} / \mathrm{d} / \mathrm{ft}^{2} \text {. }\end{array}$ \\
\hline \multirow[t]{2}{*}{ 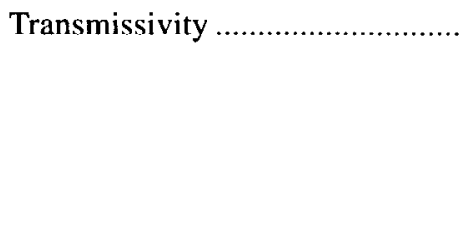 } & 1960 & HB 3 & $1: 148,000$ & $\begin{array}{l}\text { Computed from aquifer test on } 1 \text { well. Shown in } \\
\mathrm{gal} / \mathrm{d} / \mathrm{ft} \text {. }\end{array}$ \\
\hline & 1974 & WRIR $4-74$ & $1: 24,000$ & $\begin{array}{l}\text { Estimated from lithologic logs, aquifer tests, or specific } \\
\text { capacity data. Shown in intervals of } 4,000 \mathrm{ft}^{2} / \mathrm{d} \\
(30,000 \mathrm{gal} / \mathrm{d} / \mathrm{ft}) . \text { For Blackstone and Abbott Run } \\
\text { Basins. }\end{array}$ \\
\hline \multirow[t]{3}{*}{ Drainage divides............................... } & 1974 & WRIR 4-74 & $1: 24,000$ & For Blackstone and Abbott Run Basins. \\
\hline & 1985 & RAR 1 & $1: 24,000$ & For Blackstone Basin. \\
\hline & 1990 & WRIR 89-4164 & $1: 125,000$ & $\begin{array}{l}\text { For Blackstone and Abbott Run Basins. Not on } \\
\text { topographic base. }\end{array}$ \\
\hline 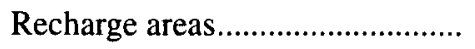 & 1985 & RAR 1 & $1: 24,000$ & For Blackstone ground-water reservoir. \\
\hline \multirow[t]{2}{*}{ Ground-water reservoirs................. } & 1974 & WRIR 4-74 & $1: 24,000$ & $\begin{array}{l}\text { Yield estimated from analytical models for Blackstone } \\
\text { ground-water reservoir. }\end{array}$ \\
\hline & 1985 & RAR 1 & $1: 24,000$ & Shows Blackstone ground-water reservoir. \\
\hline \multirow[t]{3}{*}{ 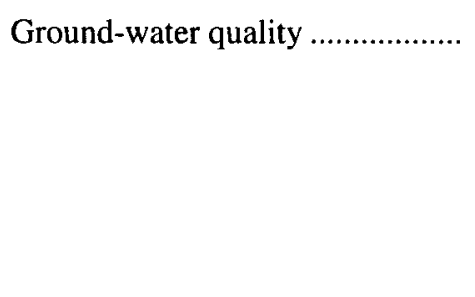 } & 1950 & GB 5 & $1: 15,700$ & $\begin{array}{l}\text { Major inorganic constituents, physical properties; for } 1 \\
\text { well. Hardness for several wells. For the city of } \\
\text { Woonsocket. }\end{array}$ \\
\hline & 1953 & GB 6 & $1: 122,000$ & $\begin{array}{l}\text { Major inorganic constituents, physical properties. For } 1 \\
\text { well. Not on topographic base. }\end{array}$ \\
\hline & 1974 & HB 7 & $1: 24,000$ & $\begin{array}{l}\text { Major inorganic constituents, physical properties. For } 4 \\
\text { wells. For Blackstone Basin. }\end{array}$ \\
\hline
\end{tabular}


Table 19. Geologic and hydrologic information for the Georgiaville Quadrangle

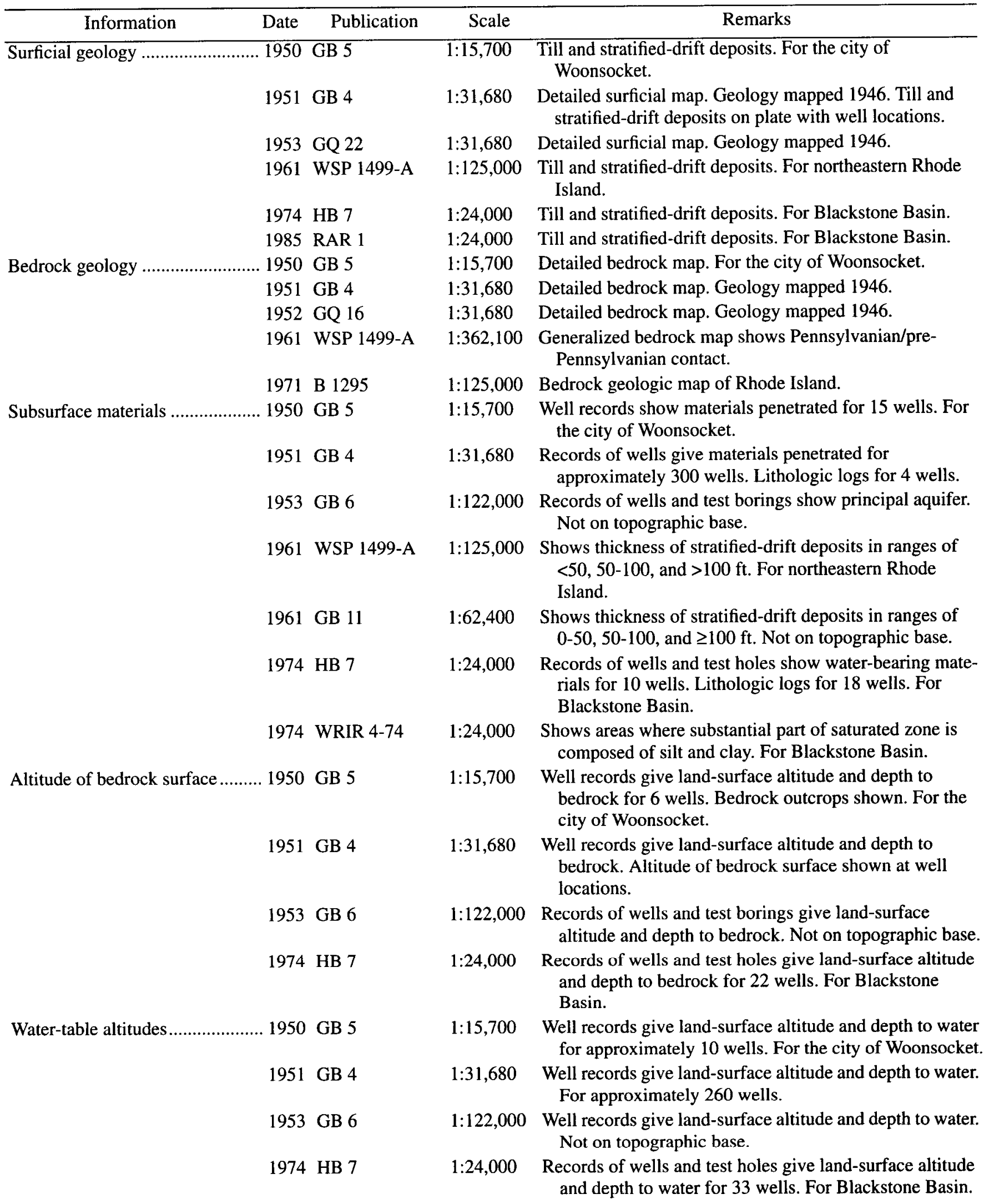


Table 19. Geologic and hydrologic information for the Georgiaville Quadrangle--Continued

\begin{tabular}{|c|c|c|c|c|}
\hline Information & Date & Publication & Scale & Remarks \\
\hline \multirow[t]{2}{*}{ Saturated thickness........ } & 1974 & WRIR 18-74 & $1: 24,000$ & $\begin{array}{l}\text { Lines of equal saturated thickness, } 20 \mathrm{ft} \text { interval. For } \\
\text { Branch Basin. }\end{array}$ \\
\hline & 1974 & WRIR 4-74 & $1: 24,000$ & $\begin{array}{l}\text { Lines of equal saturated thickness; } 10,30 \text {, and } 40 \mathrm{ft} \\
\text { intervals. For Blackstone Basin. }\end{array}$ \\
\hline \multirow[t]{2}{*}{ Hydraulic conductivity } & 1974 & WRIR 18-74 & $1: 24,000$ & $\begin{array}{l}\text { Estimated from lithologic logs and specific capacity data. } \\
\text { Shown in } \mathrm{ft} / \mathrm{d} \text {. For } 2 \text { wells. For Branch Basin. }\end{array}$ \\
\hline & 1992 & OFR 91-481 & NA & Values for till in $\mathrm{cm} / \mathrm{s}$ for 1 site. \\
\hline \multirow[t]{2}{*}{ Transmissivity .............. } & 1974 & WRIR 18-74 & $1: 24,000$ & $\begin{array}{l}\text { Estimated from lithologic logs and specific capacity data. } \\
\text { Shown in intervals of } 2,500 \text { and } 3,000 \mathrm{ft}^{2} / \mathrm{d} \text {. For Branch } \\
\text { Basin. }\end{array}$ \\
\hline & 1974 & WRIR 4-74 & $1: 24,000$ & $\begin{array}{l}\text { Estimated from lithologic logs. Shown in intervals of } \\
4,000 \mathrm{ft}^{2} / \mathrm{d}(30,000 \mathrm{gal} / \mathrm{d} / \mathrm{ft}) \text {. For Blackstone Basin. }\end{array}$ \\
\hline \multirow[t]{5}{*}{ Drainage divides..... } & 1974 & WRIR 18-74 & $1: 24,000$ & For Branch Basin. \\
\hline & 1974 & HB 7 & $1,24,000$ & For Blackstone and Branch Basins. \\
\hline & 1974 & WRIR 4-74 & $1: 24,000$ & For Blackstone and Branch Basins. \\
\hline & 1985 & RAR 1 & $1: 24,000$ & For Blackstone Basin. \\
\hline & 1990 & WRIR 89-4164 & $1: 125,000$ & $\begin{array}{l}\text { For Branch, Woonasquatucket, Blackstone, and North } \\
\text { Branch Pawtuxet Basins. Not on topographic base. }\end{array}$ \\
\hline Recharge areas............... & .1985 & RAR 1 & $1: 24,000$ & For Blackstone ground-water reservoir. \\
\hline \multirow[t]{2}{*}{ Ground-water reservoir } & 1974 & WRIR 4-74 & $1: 24,000$ & $\begin{array}{l}\text { Yield estimated from mathematical model for Lower } \\
\text { Branch-Blackstone ground-water reservoir. }\end{array}$ \\
\hline & 1974 & WRIR 18-74 & $1: 24,000$ & $\begin{array}{l}\text { Yield estimated for part of the Slatersville ground-water } \\
\text { reservoir, using a mathematical model. }\end{array}$ \\
\hline Induced infiltration ....... & 1974 & WRIR 18-74 & NA & Rates estimated for Branch Basin. \\
\hline \multirow[t]{7}{*}{ Ground-water quality .. } & 1950 & GB 5 & $1: 15,700$ & Hardness for a few wells. For the city of Woonsocket. \\
\hline & 1951 & GB 4 & $1: 31,680$ & $\begin{array}{l}\text { Major inorganic constituents, physical properties; for } 12 \\
\text { wells. Temperature for } 18 \text { wells. Hardness for } 16 \text { wells. }\end{array}$ \\
\hline & 1953 & GB 6 & $1: 122,000$ & $\begin{array}{l}\text { Major inorganic constituents, physical properties. For } 12 \\
\text { wells. Not on topographic base. }\end{array}$ \\
\hline & 1961 & WSP 1499-A & $1: 125,000$ & $\begin{array}{l}\text { Major inorganic constituents, physical properties. For } 5 \\
\text { wells. }\end{array}$ \\
\hline & 1974 & HB 7 & $1: 24,000$ & $\begin{array}{l}\text { Major inorganic constituents, physical properties. For } 4 \\
\text { wells. For Blackstone Basin. }\end{array}$ \\
\hline & 1974 & WRIR 18-74 & $\begin{array}{l}1: 133,300 \\
1: 24,000\end{array}$ & $\begin{array}{l}\text { Major inorganic constituents, physical properties. For } 4 \\
\text { wells. For Branch Basin. }\end{array}$ \\
\hline & 1974 & WRIR 4-74 & various & $\begin{array}{l}\text { Major inorganic constituents. For } 1 \text { well. For Blackstone } \\
\text { Basin. }\end{array}$ \\
\hline
\end{tabular}


Table 20. Geologic and hydrologic information for the Hope Valley Quadrangle

\begin{tabular}{|c|c|c|c|c|}
\hline Information & Date & Publication & Scale & Remarks \\
\hline \multirow[t]{9}{*}{ 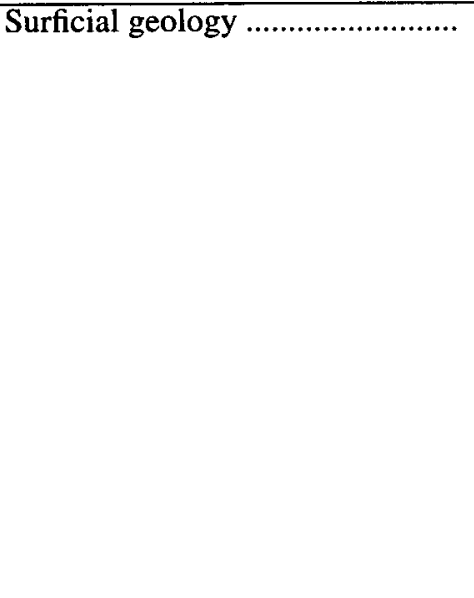 } & 1959 & GWM 6 & $1: 24,000$ & Till and stratified-drift deposits. \\
\hline & 1962 & GQ 166 & $1: 24,000$ & Detailed surficial map. Geology mapped 1956-57. \\
\hline & 1966 & WSP 1821 & $1: 24,000$ & Till deposits. For Upper Pawcatuck Basin. \\
\hline & 1966 & HB 6 & $1: 24,000$ & $\begin{array}{l}\text { Till and stratified-drift deposits. For South Branch } \\
\text { Pawtuxet Basin. }\end{array}$ \\
\hline & 1977 & WISR 3 & $1: 12,000$ & Till and stratified-drift deposits. For Beaver Basin. \\
\hline & 1980 & WISR 4 & $1: 12,000$ & $\begin{array}{l}\text { Till and stratified-drift deposits. For Lower Wood } \\
\text { Basin. }\end{array}$ \\
\hline & 1989 & WISR 5 & $1: 24,000$ & $\begin{array}{l}\text { Till and stratified-drift deposits. For Upper Wood } \\
\text { Basin. }\end{array}$ \\
\hline & 1990 & WRIR 89-4031 & $1: 44,100$ & $\begin{array}{l}\text { Till and stratified-drift deposits. For Lower Wood } \\
\text { Basin. }\end{array}$ \\
\hline & 1993 & WRIR 92-4119 & $1: 68,700$ & $\begin{array}{l}\text { Till and stratified-drift deposits. For Upper Wood } \\
\text { Basin. }\end{array}$ \\
\hline \multirow[t]{2}{*}{ Bedrock geology ............ } & 1958 & GQ 105 & $1: 31,680$ & Detailed bedrock map. Geology mapped 1952-53. \\
\hline & 1971 & В 1295 & $1: 125,000$ & Bedrock geologic map of Rhode Island. \\
\hline \multirow[t]{9}{*}{ Subsurface materials ....................... } & 1953 & GB 6 & $1: 122,000$ & $\begin{array}{l}\text { Records of wells and test borings show principal } \\
\text { aquifer. Not on topographic base. }\end{array}$ \\
\hline & 1961 & GB 11 & $1: 61,400$ & $\begin{array}{l}\text { Shows thickness of stratified-drift deposits in ranges of } \\
0-50,50-100 \text {, and } \geq 100 \mathrm{ft} \text {. Not on topographic base. }\end{array}$ \\
\hline & 1963 & GB 13 & $1: 24,000$ & $\begin{array}{l}\text { Records of wells show water-bearing materials. For } 1 \\
\text { well. }\end{array}$ \\
\hline & 1966 & HB 6 & $1: 24,000$ & $\begin{array}{l}\text { Records of wells and test borings show water-bearing } \\
\text { materials. For } 30 \text { wells. For South Branch Pawtuxet } \\
\text { Basin. }\end{array}$ \\
\hline & 1974 & WSP 2033 & $1: 48,000$ & $\begin{array}{l}\text { Map shows areas where silt or clay layers are reported } \\
\text { to separate water-bearing sand and gravel layers. }\end{array}$ \\
\hline & 1977 & WISR 3 & $1: 12,000$ & $\begin{array}{l}\text { Records of wells and test holes show water-bearing } \\
\text { materials. For } 5 \text { wells. Lithologic log for } 1 \text { well. For } \\
\text { Beaver Basin. }\end{array}$ \\
\hline & 1980 & WISR 4 & $1: 12,000$ & $\begin{array}{l}\text { Records of wells and test holes show water-bearing } \\
\text { materials. For } 12 \text { wells. For Lower Wood Basin. }\end{array}$ \\
\hline & 1989 & WISR 5 & $1: 24,000$ & $\begin{array}{l}\text { Records of wells and test holes show principal water- } \\
\text { bearing material. For approximately } 500 \text { wells. } \\
\text { Lithologic logs for approximately } 300 \text { wells. } \\
\text { Analyses of particle-size distribution for } 146 \\
\text { lithologic samples from } 11 \text { wells. For Upper Wood } \\
\text { Basin. }\end{array}$ \\
\hline & 1993 & WRIR 92-4119 & NA & Generalized geologic sections. For Upper Wood Basin. \\
\hline \multirow[t]{4}{*}{ Altitude of bedrock surface .......... } & 1953 & GB 6 & $1: 122,000$ & $\begin{array}{l}\text { Records of wells and test borings give land-surface } \\
\text { altitude and depth to bedrock. Not on topographic } \\
\text { base. }\end{array}$ \\
\hline & 1959 & GWM 6 & $1: 24,000$ & $\begin{array}{l}\text { Approximate bedrock contours in stratified drift, } 50 \mathrm{ft} \\
\text { interval. Altitude of bedrock surface shown at well } \\
\text { locations. Bedrock outcrops in stratified drift shown. }\end{array}$ \\
\hline & 1963 & GB 13 & $1: 24,000$ & $\begin{array}{l}\text { Records of wells give land-surface altitude and depth } \\
\text { to bedrock. For } 1 \text { well. }\end{array}$ \\
\hline & 1966 & HB 6 & $1: 24,000$ & $\begin{array}{l}\text { Records of wells and test borings give land-surface } \\
\text { altitude and depth to bedrock. For South Branch } \\
\text { Pawtuxet Basin. }\end{array}$ \\
\hline
\end{tabular}


Table 20. Geologic and hydrologic information for the Hope Valley Quadrangle--Continued

\begin{tabular}{|c|c|c|c|c|}
\hline Information & Datc & Publication & Scale & Remarks \\
\hline \multirow[t]{4}{*}{ Continued ............................... } & 1974 & WSP 2033 & $1: 48,000$ & $\begin{array}{l}\text { Approximate bedrock contours, } 50 \mathrm{ft} \text { interval. For } \\
\text { Lower Pawcatuck Basin. }\end{array}$ \\
\hline & 1980 & WISR 4 & $1: 12,000$ & $\begin{array}{l}\text { Records of wells and test holes give land-surface } \\
\text { altitude and depth to bedrock. For } 3 \text { wells. For } \\
\text { Lower Wood Basin. }\end{array}$ \\
\hline & 1989 & WISR 5 & $1: 24,000$ & $\begin{array}{l}\text { Records of wells and test holes give land-surface } \\
\text { altitude and depth to bedrock. For approximately } \\
100 \text { wells. Bedrock altitudes for } 36 \text { locations from } \\
\text { seismic surveys at } 4 \text { sites in stratified-drift aquifer. } \\
\text { For Upper Wood Basin. }\end{array}$ \\
\hline & 1993 & WRIR 92-4119 & $1: 54,100$ & $\begin{array}{l}\text { Shown on map, with } 20,40 \text {, and } 50 \mathrm{ft} \text { contour } \\
\text { intervals, and in generalized geologic sections. For } \\
\text { Upper Wood Basin. Not on topographic base. }\end{array}$ \\
\hline \multirow[t]{7}{*}{ Water-table altitudes ..................... } & 1953 & GB 6 & $1: 122,000$ & $\begin{array}{l}\text { Well records give land-surface altitude and depth to } \\
\text { water. Not on topographic base. }\end{array}$ \\
\hline & 1959 & GWM 6 & $1: 24,000$ & $\begin{array}{l}\text { Water-table altitudes shown at well locations. Data on } \\
\text { wells collected chiefly in } 1955 \text {. }\end{array}$ \\
\hline & 1963 & GB 13 & $1: 24,000$ & $\begin{array}{l}\text { Well records give land-surface altitude and depth to } \\
\text { water. For } 1 \text { well. }\end{array}$ \\
\hline & 1966 & HB 6 & $1: 24,000$ & $\begin{array}{l}\text { Well records give land-surface altitude and depth to } \\
\text { water. For South Branch Pawtuxet Basin. }\end{array}$ \\
\hline & 1977 & WISR 3 & $1: 12,000$ & $\begin{array}{l}\text { Well records give land-surface altitude and depth to } \\
\text { water. For } 3 \text { wells. For Beaver Basin. }\end{array}$ \\
\hline & 1980 & WISR 4 & $1: 12,000$ & $\begin{array}{l}\text { Records of wells and test holes give land-surface } \\
\text { altitude and depth to water. For } 15 \text { wells. For Lower } \\
\text { Wood Basin. }\end{array}$ \\
\hline & 1989 & WISR 5 & $1: 24,000$ & $\begin{array}{l}\text { Records of wells and test holes give land-surface } \\
\text { altitude and depth to water. For approximately } 400 \\
\text { wells. Water-level records for } 40 \text { observation wells; } \\
\text { data collected primarily 1981-86. For Upper Wood } \\
\text { Basin. }\end{array}$ \\
\hline \multirow[t]{3}{*}{ Water-table contours..................... } & 1959 & GWM 6 & $1: 24,000$ & $\begin{array}{l}\text { Approximate contours in stratified drift, } 20 \mathrm{ft} \text { interval. } \\
\text { Data on wells collected chiefly in } 1955 \text {. }\end{array}$ \\
\hline & 1974 & WSP 2033 & $1: 48,000$ & $\begin{array}{l}\text { Water-table contours in stratified drift, } 10 \mathrm{ft} \text { interval. } \\
\text { For Lower Pawcatuck Basin. }\end{array}$ \\
\hline & 1993 & WRIR 92-4119 & $1: 54,100$ & $\begin{array}{l}\text { Water-table contours in stratified drift, } 10 \mathrm{ft} \text { interval. } \\
\text { For Upper Wood Basin. Not on topographic base. }\end{array}$ \\
\hline \multirow[t]{2}{*}{ Saturated thickness...................... } & 1974 & WSP 2033 & $1: 48,000$ & $\begin{array}{l}\text { Lines of equal saturated thickness, } 20 \mathrm{ft} \text { interval. For } \\
\text { Lower Pawcatuck Basin. }\end{array}$ \\
\hline & 1993 & WRIR 92-4119 & $1: 54,100$ & $\begin{array}{l}\text { Lines of equal saturated thickness, } 20 \text { and } 40 \mathrm{ft} \\
\text { intervals. For Upper Wood Basin. Not on } \\
\text { topographic base. }\end{array}$ \\
\hline Hydraulic conductivity .................. & 1993 & WRIR 92-4119 & NA & $\begin{array}{l}\text { Range of values for horizontal and vertical hydraulic } \\
\text { conductivity estimated from aquifer-test data for } 11 \\
\text { sites. Shown in } \mathrm{ft} / \mathrm{d} \text {. For Upper Wood Basin. }\end{array}$ \\
\hline 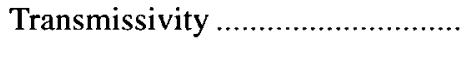 & 1974 & WSP 2033 & $1: 48,000$ & $\begin{array}{l}\text { Lines of equal transmissivity, intervals of } 2,500 \text { and } \\
3,000 \mathrm{ft}^{2} / \mathrm{d} \text {. For Lower Pawcatuck Basin. }\end{array}$ \\
\hline
\end{tabular}


Table 20. Geologic and hydrologic information for the Hope Valley Quadrangle--Continued

\begin{tabular}{|c|c|c|c|c|}
\hline Information & Date & Publication & Scale & Remarks \\
\hline Transmissivity--Continued............ & 1993 & WRIR 92-4119 & $1: 54,100$ & $\begin{array}{l}\text { Table shows range of values estimated from aquifer } \\
\text { test data for each of } 11 \text { sites. Shown in } \mathrm{ft}^{2} / \mathrm{d} \text {. Map } \\
\text { shows lines of equal transmissivity with variable } \\
\text { interval in } \mathrm{ft}^{2} / \mathrm{d} \text {. For Upper Wood Basin. Not on } \\
\text { topographic base. }\end{array}$ \\
\hline \multirow[t]{10}{*}{ Drainage divides................................ } & 1963 & GB 13 & $1: 24,000$ & For Upper Pawcatuck Basin. \\
\hline & 1966 & WSP 1821 & $1: 24,000$ & For Upper Pawcatuck Basin and subbasin. \\
\hline & 1966 & HB 6 & $1: 24,000$ & For South Branch Pawtuxet Basin. \\
\hline & 1974 & WSP 2033 & $1: 48,000$ & For Lower Pawcatuck Basin. \\
\hline & 1977 & WISR 3 & $1: 12,000$ & For Beaver Basin. \\
\hline & 1980 & WISR 4 & $1: 12,000$ & For Lower Wood Basin. \\
\hline & 1989 & WISR 5 & $1: 24,000$ & For Upper Wood Basin. \\
\hline & 1990 & WRIR 89-4031 & $1: 44,100$ & For Lower Wood Basin. \\
\hline & 1990 & WRIR 89-4164 & $1: 125,000$ & $\begin{array}{l}\text { For South Branch Pawtuxet Basin. Not on topographic } \\
\text { base. }\end{array}$ \\
\hline & 1993 & WRIR 92-4119 & $1: 68,700$ & For Upper Wood Basin. \\
\hline 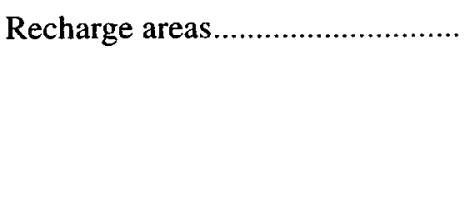 & 1993 & WRIR 92-4119 & variable & $\begin{array}{l}\text { Maps show estimated areas in stratified drift } \\
\text { contributing water to pumped wells under various } \\
\text { ground-water-development alternatives, using } \\
\text { computer simulation model. For Upper Wood } \\
\text { ground-water reservoir. Not on topographic base. }\end{array}$ \\
\hline \multirow[t]{3}{*}{ Ground-water reservoirs.................. } & 1974 & WSP 2033 & $1: 48,000$ & $\begin{array}{l}\text { Yield estimated from mathematical model for Upper } \\
\text { Wood ground-water reservoir. }\end{array}$ \\
\hline & 1989 & WISR 5 & $1: 24,000$ & $\begin{array}{l}\text { Aquifer-test data for } 11 \text { sites, 1980-86. For Upper } \\
\text { Wood ground-water reservoir. }\end{array}$ \\
\hline & 1993 & WRIR 92-4119 & NA & $\begin{array}{l}\text { Aquifer-test data for } 11 \text { sites. Estimated potential } \\
\text { yields at } 11 \text { sites, under various ground-water- } \\
\text { development alternatives, using computer } \\
\text { simulation model. For Upper Wood ground-water } \\
\text { reservoir. }\end{array}$ \\
\hline \multirow[t]{2}{*}{ 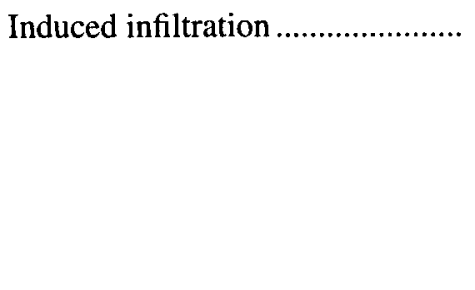 } & 1974 & WSP 2033 & $1: 48,000$ & $\begin{array}{l}\text { Vertical hydraulic conductivity of streambed } \\
\text { sediments used to estimate potential recharge by } \\
\text { induced infiltration. For Upper Wood ground-water } \\
\text { reservoir. }\end{array}$ \\
\hline & 1993 & WRIR $92-4119$ & NA & $\begin{array}{l}\text { Estimates of amount of induced infiltration under } \\
\text { various ground-water-development alternatives. For } \\
\text { Upper Wood ground-water reservoir. }\end{array}$ \\
\hline \multirow[t]{5}{*}{ 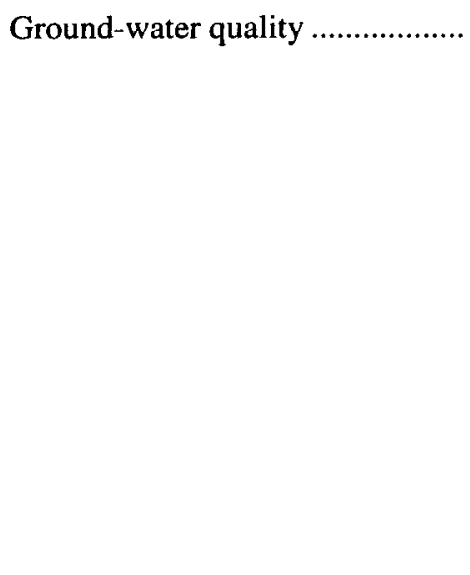 } & 1966 & HB 6 & $1: 24,000$ & $\begin{array}{l}\text { Major inorganic constituents, physical properties. For } \\
1 \text { well. For South Branch Pawtuxet Basin. }\end{array}$ \\
\hline & 1974 & WSP 2033 & $1: 48,000$ & $\begin{array}{l}\text { Major inorganic constituents, physical properties. For } \\
3 \text { wells. For Lower Pawcatuck Basin. }\end{array}$ \\
\hline & 1977 & WISR 3 & $1: 12,000$ & $\begin{array}{l}\text { Major inorganic constituents, physical properties. For } \\
1 \text { well. For Beaver Basin. }\end{array}$ \\
\hline & 1989 & WISR 5 & $1: 24,000$ & $\begin{array}{l}\text { Major inorganic constituents, physical properties, } \\
\text { nutrients. For approximately } 50 \text { wells. Trace metals, } \\
\text { other trace constituents, and pesticides for } 4 \text { wells. } \\
\text { For Upper Wood Basin. }\end{array}$ \\
\hline & 1993 & WRIR 92-4119 & NA & $\begin{array}{l}\text { Summary of major inorganic constituents, physical } \\
\text { properties. Selected trace elements and synthetic } \\
\text { organic compounds, for } 5 \text { wells. For Upper Wood } \\
\text { Basin. }\end{array}$ \\
\hline
\end{tabular}


Table 21. Geologic and hydrologic information for the Kingston Quadrangle

\begin{tabular}{|c|c|c|c|c|}
\hline Information & Date & Publication & Scale & Remarks \\
\hline \multirow[t]{7}{*}{ Surficial geology .................................. } & 1956 & GB 9 & $1: 31,680$ & Till, stratified drift, and mixed deposits. \\
\hline & 1960 & B $1071-\mathrm{I}$ & $1: 24,000$ & Detailed surficial map. Geology mapped 1954, 1958. \\
\hline & 1966 & WSP 1821 & $1: 24,000$ & $\begin{array}{l}\text { Till, stratified drift, and mixed deposits. Lacustrine } \\
\text { deposits differentiated. For Upper Pawcatuck Basin. }\end{array}$ \\
\hline & 1976 & WISR 2 & $1: 12,000$ & Till and stratified-drift deposits. For Chipuxet Basin. \\
\hline & 1977 & WISR 3 & $1: 12,000$ & $\begin{array}{l}\text { Till, stratified drift, and mixed deposits. For Beaver- } \\
\text { Pasquiset Basin. }\end{array}$ \\
\hline & 1985 & WRIR $85-4190$ & $1: 36,200$ & $\begin{array}{l}\text { Till, stratified drift, and mixed deposits. For Beaver- } \\
\text { Pasquiset Basin. }\end{array}$ \\
\hline & $\mathrm{U}$ & RAR 3 & $1: 24,000$ & $\begin{array}{l}\text { Till and stratified-drift deposits. For Chipuxet Basin. } \\
\text { Unpublished report available at Rhode Island } \\
\text { Subdistrict Office, U.S. Geological Survey. }\end{array}$ \\
\hline \multirow[t]{2}{*}{ Bedrock geology ……......................... } & 1964 & B 1158-E & $1: 24,000$ & Detailed bedrock map. Geology mapped 1957-58. \\
\hline & 1971 & B 1295 & $1: 125,000$ & Bedrock geologic map of Rhode Island. \\
\hline \multirow[t]{12}{*}{ Subsurface materials .......................... } & 1953 & GB 6 & $1: 122,000$ & $\begin{array}{l}\text { Records of wells and test borings show principal } \\
\text { aquifer. Lithologic logs for } 13 \text { wells. Not on topo- } \\
\text { graphic base. }\end{array}$ \\
\hline & 1956 & GB 9 & $1: 31,680$ & $\begin{array}{l}\text { Records of wells and test borings show water-bearing } \\
\text { materials for approximately } 500 \text { wells. Lithologic } \\
\text { logs available for } 36 \text { wells. }\end{array}$ \\
\hline & 1960 & HB 3 & $1: 148,000$ & Lithologic logs for 2 wells. \\
\hline & 1961 & GB 11 & $1: 61,400$ & $\begin{array}{l}\text { Shows thickness of stratified-drift deposits in ranges of } \\
0-50,50-100 \text {, and } \geq 100 \mathrm{ft} \text {. Not on topographic base. }\end{array}$ \\
\hline & 1963 & GB 13 & $1: 24,000$ & $\begin{array}{l}\text { Well records show water-bearing materials. Lithologic } \\
\text { logs for some wells. }\end{array}$ \\
\hline & 1966 & WSP 1821 & $1: 24,000$ & $\begin{array}{l}\text { Shows approximate area of buried lens of coarse sand } \\
\text { and gravel. }\end{array}$ \\
\hline & 1976 & WISR 2 & $1: 12,000$ & $\begin{array}{l}\text { Records of wells and test holes show water-bearing } \\
\text { material for } 124 \text { wells. Detailed lithologic logs for } 94 \\
\text { wells. For Chipuxet Basin. }\end{array}$ \\
\hline & 1977 & WISR 3 & $1: 12,000$ & $\begin{array}{l}\text { Records of wells and test holes show water-bearing } \\
\text { materials for approximately } 40 \text { wells. Detailed } \\
\text { lithologic logs for several wells. For Beaver- } \\
\text { Pasquiset Basin. }\end{array}$ \\
\hline & 1977 & OFR 77-561 & NA & $\begin{array}{l}\text { Generalized geologic section near University of Rhode } \\
\text { Island supply wells. Lithologic logs for } 16 \text { wells. For } \\
\text { Chipuxet Basin. }\end{array}$ \\
\hline & 1984 & WRIR 83-4231 & NA & $\begin{array}{l}\text { Generalized geologic sections. Lithologic logs for some } \\
\text { wells. For Chipuxet Basin. }\end{array}$ \\
\hline & 1985 & WRIR 84-4254 & NA & Generalized geologic sections. For Chipuxet Basin. \\
\hline & 1985 & WRIR $85-4190$ & NA & $\begin{array}{l}\text { Generalized geologic sections. For Beaver-Pasquiset } \\
\text { Basin. }\end{array}$ \\
\hline \multirow[t]{3}{*}{ Altitude of bedrock surface .............. } & 1953 & GB 6 & $1: 122,000$ & $\begin{array}{l}\text { Records of wells and test borings give land-surface alti- } \\
\text { tude and depth to bedrock. Not on topographic base. }\end{array}$ \\
\hline & 1956 & GB 9 & $1: 31,680$ & $\begin{array}{l}\text { Approximate bedrock contours in stratified drift and } \\
\text { mixed deposits, } 50 \mathrm{ft} \text { interval. Altitude of bedrock at } \\
\text { well locations. }\end{array}$ \\
\hline & 1963 & GB 13 & $1: 24,000$ & $\begin{array}{l}\text { Altitude of bedrock determined from seismic data and } \\
\text { well records. }\end{array}$ \\
\hline
\end{tabular}


Table 21. Geologic and hydrologic information for the Kingston Quadrangle--Continued

\begin{tabular}{|c|c|c|c|c|}
\hline Information & Date & Publication & Scale & Remarks \\
\hline \multirow[t]{5}{*}{ 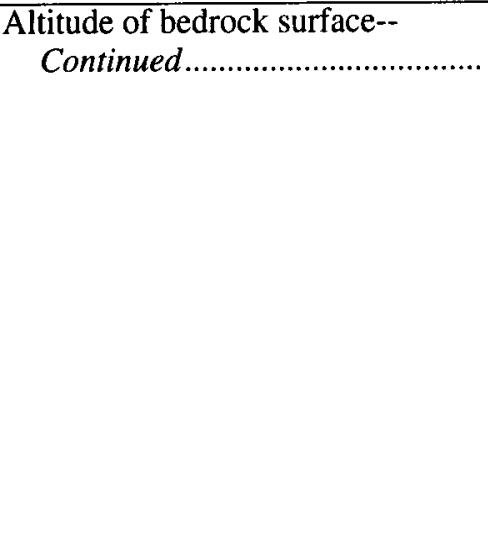 } & 1974 & WSP 2033 & $1: 48,000$ & $\begin{array}{l}\text { Approximate bedrock contours, } 50 \mathrm{ft} \text { interval. For } \\
\text { Lower Pawcatuck Basin. }\end{array}$ \\
\hline & 1976 & WISR 2 & $1: 12,000$ & $\begin{array}{l}\text { Records of wells and test holes give land-surface } \\
\text { altitude and depth to bedrock. For } 2 \text { wells. For } \\
\text { Chipuxet Basin. }\end{array}$ \\
\hline & 1977 & WISR 3 & $1: 12,000$ & $\begin{array}{l}\text { Records of wells and test holes give land-surface } \\
\text { altitude and depth to bedrock. For } 10 \text { wells. For } \\
\text { Beaver-Pasquiset Basin. }\end{array}$ \\
\hline & 1985 & WRIR 84-4254 & $1: 24,000$ & $\begin{array}{l}\text { Bedrock contours, } 25 \text { and } 50 \mathrm{ft} \text { intervals. For Chipuxet } \\
\text { Basin. }\end{array}$ \\
\hline & 1985 & WRIR 85-4190 & NA & $\begin{array}{l}\text { Generalized geologic sections show depth to bedrock. } \\
\text { For Beaver-Pasquiset Basin. }\end{array}$ \\
\hline \multirow[t]{5}{*}{ Water-table altitudes ............................ } & 1953 & GB 6 & $1: 122,000$ & $\begin{array}{l}\text { Well records give land-surface altitude and depth to } \\
\text { water. Not on topographic base. }\end{array}$ \\
\hline & 1956 & GB 9 & $1: 31,680$ & $\begin{array}{l}\text { Records give land-surface altitude and depth to water } \\
\text { for more than } 400 \text { wells. }\end{array}$ \\
\hline & 1963 & GB 13 & $1: 24,000$ & $\begin{array}{l}\text { Well records give land-surface altitude and depth to } \\
\text { water. Table of extreme values for some wells. }\end{array}$ \\
\hline & 1976 & WISR 2 & $1: 12,000$ & $\begin{array}{l}\text { Records of wells and test holcs give land-surface } \\
\text { altitude and depth to water. For } 138 \text { wells. For } \\
\text { Chipuxet Basin. }\end{array}$ \\
\hline & 1977 & WISR 3 & $1: 12,000$ & $\begin{array}{l}\text { Records of wells and test holes give land-surface } \\
\text { altitude and depth to water. For } 40 \text { wells. For Beaver- } \\
\text { Pasquiset Basin. }\end{array}$ \\
\hline \multirow[t]{6}{*}{ 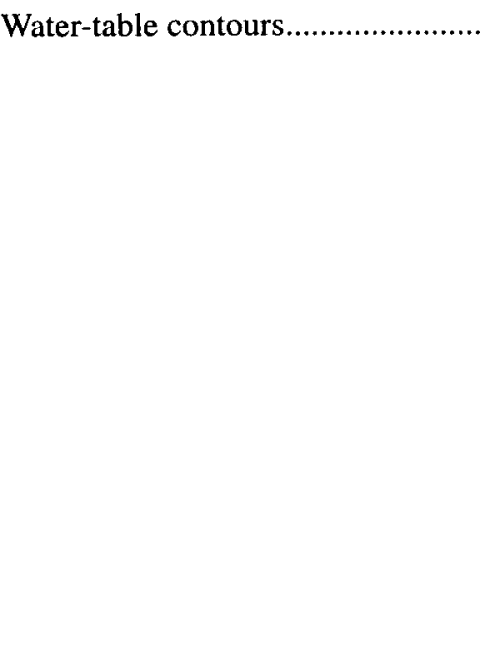 } & 1956 & GB 9 & $1: 31,680$ & $\begin{array}{l}\text { Approximate contours, } 10 \text { and } 20 \mathrm{ft} \text { intervals. Not on } \\
\text { topographic base. }\end{array}$ \\
\hline & 1966 & WSP 1821 & $1: 24,000$ & $\begin{array}{l}\text { Contours in stratified drift, } 5 \mathrm{ft} \text { interval. Water-table } \\
\text { altitude shown at well locations. For Upper } \\
\text { Pawcatuck Basin. }\end{array}$ \\
\hline & 1974 & WSP 2033 & $1: 48,000$ & $\begin{array}{l}\text { Water-table contours in stratified drift, } 10 \mathrm{ft} \text { interval. } \\
\text { For Lower Pawcatuck Basin. }\end{array}$ \\
\hline & 1985 & WRIR 84-4254 & $1: 24,000$ & $\begin{array}{l}\text { Water-table contours in stratified drift, August 1959; } 1 \text {, } \\
2 \text {, and } 5 \mathrm{ft} \text { intervals. For Chipuxet Basin. }\end{array}$ \\
\hline & 1985 & WRIR $85-4190$ & $1: 36,200$ & $\begin{array}{l}\text { Water-table contours in stratified drift, } 5 \text { and } 10 \mathrm{ft} \\
\text { intervals. August-November 1975. For Beaver- } \\
\text { Pasquiset Basin. }\end{array}$ \\
\hline & $\mathrm{U}$ & RAR 3 & $1: 24,000$ & $\begin{array}{l}\text { Water-table contours; } 1,2 \text {, and } 5 \mathrm{ft} \text { intervals. For } \\
\text { Chipuxet Basin. Unpublished report available at } \\
\text { Rhode Island Subdistrict Office, U.S. Geological } \\
\text { Survey. }\end{array}$ \\
\hline \multirow[t]{3}{*}{ 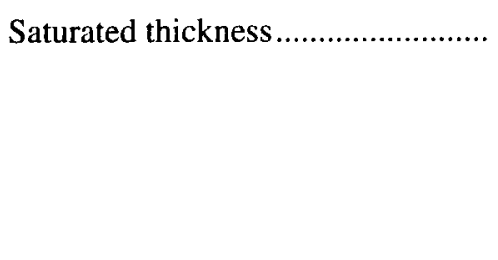 } & 1966 & WSP 1821 & $1: 24,000$ & $\begin{array}{l}\text { Lines of equal saturated thickness, } 25 \text { and } 50 \mathrm{ft} \\
\text { intervals. For Upper Pawcatuck Basin. }\end{array}$ \\
\hline & 1974 & WSP 2033 & $1: 48,000$ & $\begin{array}{l}\text { Lines of equal saturated thickness, } 20 \mathrm{ft} \text { interval. For } \\
\text { Lower Pawcatuck Basin. }\end{array}$ \\
\hline & 1985 & WRIR 85-4190 & $1: 36,200$ & $\begin{array}{l}\text { Lines of equal saturated thickness, } 20 \mathrm{ft} \text { interval. For } \\
\text { Beaver-Pasquiset Basin. Not on topographic base. }\end{array}$ \\
\hline \multirow[t]{2}{*}{ Hydraulic conductivity ...................... } & 1960 & HB 3 & $1: 148,000$ & $\begin{array}{l}\text { Computed from aquifer test on } 1 \text { well. Shown in } \\
\mathrm{gal} / \mathrm{d} / \mathrm{ft}^{2} \text {. }\end{array}$ \\
\hline & 1963 & GB 13 & $1: 24,000$ & $\begin{array}{l}\text { Computed from laboratory analysis of sediment } \\
\text { samples. Shown in gal/d//ft } \mathrm{ft}^{2} \text {. }\end{array}$ \\
\hline
\end{tabular}


Table 21. Geologic and hydrologic information for the Kingston Quadrangle--Continued

\begin{tabular}{|c|c|c|c|c|}
\hline Information & Date & Publication & Scale & Remarks \\
\hline \multicolumn{5}{|c|}{ Hydraulic conductivity-- } \\
\hline \multirow[t]{4}{*}{ 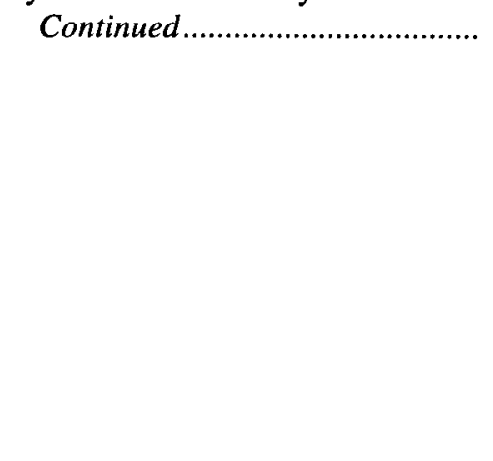 } & 1966 & WSP 1821 & $1: 24,000$ & $\begin{array}{l}\text { Computed from aquifer tests, laboratory tests, and } \\
\text { specific capacity data. Shown in ranges of }<1-20,20- \\
100,100-1,000 \text {, and }>1,000 \mathrm{gal} / \mathrm{d} / \mathrm{ft}^{2} \text {. Well locations } \\
\text { shown. For Upper Pawcatuck Basin. }\end{array}$ \\
\hline & 1984 & WRIR 83-4231 & various & $\begin{array}{l}\text { Estimated from lithologic logs and from aquifer-test } \\
\text { data. Shown in } \mathrm{ft} / \mathrm{d} \text {. For } 14 \text { sites. For Chipuxet Basin. }\end{array}$ \\
\hline & 1985 & WRIR 84-4254 & $1: 24,000$ & $\begin{array}{l}\text { Estimated from lithologic logs and aquifer-test data. } \\
\text { Shown in ranges of 5-50, 50-100, and }>100 \mathrm{ft} / \mathrm{d} \text {. For } \\
\text { Chipuxet Basin. Maps in text show ranges for } 4 \\
\text { layers within aquifer. }\end{array}$ \\
\hline & 1992 & OFR 91-481 & NA & Values for till in $\mathrm{cm} / \mathrm{s}$ for 4 sites. \\
\hline \multirow[t]{8}{*}{ 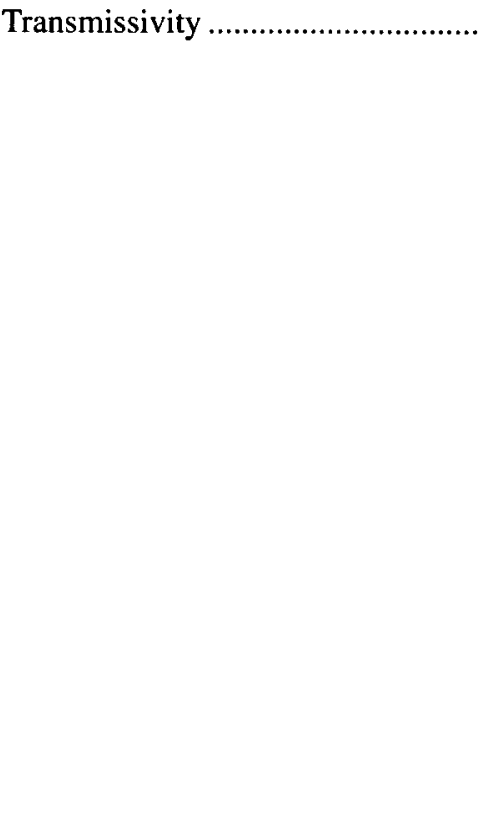 } & 1956 & GB 9 & $1: 31,680$ & $\begin{array}{l}\text { Computed from specific capacity data from aquifer tests } \\
\text { on } 5 \text { wells. Shown in gal/d/ft. }\end{array}$ \\
\hline & 1960 & HB 3 & $1: 148,000$ & $\begin{array}{l}\text { Computed from aquifer test on } 1 \text { well. Shown in } \\
\mathrm{gal} / \mathrm{d} / \mathrm{ft} \text {. }\end{array}$ \\
\hline & 1966 & WSP 1821 & $1: 24,000$ & $\begin{array}{l}\text { Estimated from aquifer tests and specific capacity data. } \\
\text { Shown in gal/d/ft. For Upper Pawcatuck Basin. }\end{array}$ \\
\hline & 1974 & WSP 2033 & $1: 48,000$ & $\begin{array}{l}\text { Lines of equal transmissivity, intervals of } 2,500 \text { and } \\
3,000 \mathrm{ft}^{2} / \mathrm{d} \text {. For Lower Pawcatuck Basin. }\end{array}$ \\
\hline & 1977 & OFR 77-561 & NA & $\begin{array}{l}\text { Computed from aquifer test on } 1 \text { well. Shown in } \mathrm{ft}^{2} / \mathrm{d} \text {. } \\
\text { For Chipuxet Basin. }\end{array}$ \\
\hline & 1984 & WRIR 83-4231 & NA & $\begin{array}{l}\text { Estimated from lithologic logs, specific capacity data, } \\
\text { and aquifer-test data. Shown in } \mathrm{ft}^{2} / \mathrm{d} \text {. For } 16 \text { sites. For } \\
\text { Chipuxet Basin. }\end{array}$ \\
\hline & 1985 & WRIR $84-4254$ & NA & $\begin{array}{l}\text { Estimated from lithologic logs, specific capacity data, } \\
\text { and aquifer-test data. For } 16 \text { sites. For Chipuxet } \\
\text { Basin. }\end{array}$ \\
\hline & 1985 & WRIR 85-4190 & $1: 36,200$ & $\begin{array}{l}\text { Lines of equal transmissivity, interval of } 3,000 \mathrm{ft}^{2} / \mathrm{d} \text {. } \\
\text { For Beaver-Pasquiset Basin. Not on topographic } \\
\text { base. Estimated from lithologic logs and aquifer-test } \\
\text { data. }\end{array}$ \\
\hline \multirow[t]{6}{*}{ Drainage divides..................................... } & 1963 & GB 13 & $1: 24,000$ & $\begin{array}{l}\text { Ground-water and surface-water divides. For Upper } \\
\text { Pawcatuck Basin. }\end{array}$ \\
\hline & 1966 & WSP 1821 & $1: 24,000$ & $\begin{array}{l}\text { Ground-water and surface-water divides. For Upper } \\
\text { Pawcatuck Basin and subbasins. }\end{array}$ \\
\hline & 1974 & WSP 2033 & $1: 48,000$ & For Lower Pawcatuck Basin. \\
\hline & 1977 & WISR 3 & $1: 12,000$ & For Beaver-Pasquiset Basin. \\
\hline & 1985 & WRIR 85-4190 & $1: 36,200$ & $\begin{array}{l}\text { For Beaver-Pasquiset Basin. Ground-water divide } \\
\text { shown where not coincident with surface-water } \\
\text { divide. }\end{array}$ \\
\hline & $\mathrm{U}$ & RAR 3 & $1: 24,000$ & $\begin{array}{l}\text { For Chipuxet Basin. Unpublished report available at } \\
\text { Rhode Island Subdistrict Office, U.S. Geological } \\
\text { Survey }\end{array}$ \\
\hline 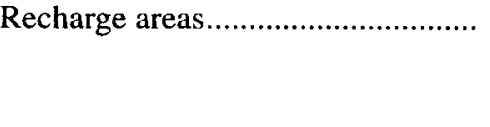 & $\mathrm{U}$ & RAR 3 & $1: 24,000$ & $\begin{array}{l}\text { For Chipuxet ground-water reservoir. Unpublished } \\
\text { report, available at Rhode Island Subdistrict Office, } \\
\text { U.S. Geological Survey. }\end{array}$ \\
\hline \multirow[t]{2}{*}{ 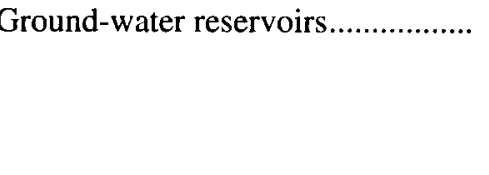 } & 1966 & WSP 1821 & NA & $\begin{array}{l}\text { Yields estimated for Chipuxet and Usquepaug-Queen } \\
\text { ground-water reservoirs. }\end{array}$ \\
\hline & 1974 & WSP 2033 & $1: 48,000$ & $\begin{array}{l}\text { Yield estimated from mathematical model for Beaver- } \\
\text { Pasquiset ground-water reservoir. }\end{array}$ \\
\hline
\end{tabular}


Table 21. Geologic and hydrologic information for the Kingston Quadrangle--Continued

\begin{tabular}{|c|c|c|c|c|}
\hline Information & Date & Publication & Scale & Remarks \\
\hline \multirow[t]{5}{*}{$\begin{array}{l}\text { Ground-water reservoirs-- } \\
\text { Continued }\end{array}$} & 1976 & WISR 2 & various & $\begin{array}{l}\text { Aquifer tests for } 13 \text { sites. For Chipuxet ground-water } \\
\text { reservoir. }\end{array}$ \\
\hline & 1977 & WISR 3 & $1: 12,000$ & $\begin{array}{l}\text { Well efficiency tests and aquifer test for } 1 \text { site. For } \\
\text { Beaver-Pasquiset ground-water reservoir. }\end{array}$ \\
\hline & 1985 & WRIR $85-4190$ & various & $\begin{array}{l}\text { Aquifer-test data for } 1 \text { site. Estimated potential well } \\
\text { yields for } 1 \text { site, under various ground-water- } \\
\text { development alternatives, using computer simulation } \\
\text { model. For Beaver-Pasquiset ground-water reservoir. }\end{array}$ \\
\hline & 1985 & WRIR 84-4254 & various & $\begin{array}{l}\text { Aquifer-test data for } 16 \text { sites. Estimated potential well } \\
\text { yields for } 8 \text { sites, under various ground-water- } \\
\text { development alternatives, using computer simulation } \\
\text { model. For Chipuxet ground-water reservoir. }\end{array}$ \\
\hline & $\mathbf{U}$ & RAR 3 & $1: 24,000$ & $\begin{array}{l}\text { Shows Chipuxet ground-water reservoir. Unpublished } \\
\text { report, available at Rhode Island Subdistrict Office, } \\
\text { U.S. Geological Survey. }\end{array}$ \\
\hline \multirow[t]{4}{*}{ 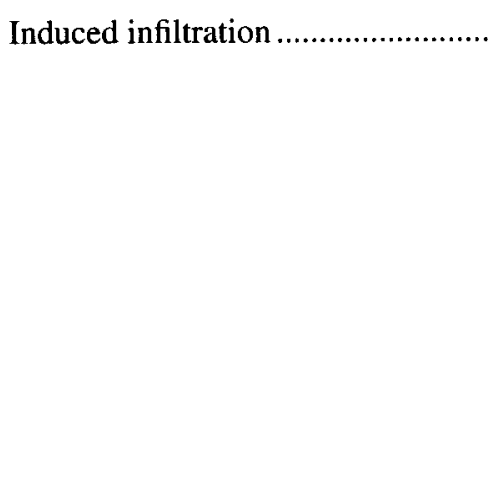 } & 1974 & WSP 2033 & $1: 48,000$ & $\begin{array}{l}\text { Vertical hydraulic conductivity of streambed sediments } \\
\text { used to estimate potential recharge by induced } \\
\text { infiltration. For Beaver-Pasquiset ground-water } \\
\text { reservoir. }\end{array}$ \\
\hline & 1977 & OFR 77-561 & NA & $\begin{array}{l}\text { Discussed for public-supply wells near pond on } \\
\text { Chipuxet River. }\end{array}$ \\
\hline & 1985 & WRIR $85-4190$ & NA & $\begin{array}{l}\text { Estimates of amount of induced infiltration under } \\
\text { various ground-water-development alternatives. For } \\
\text { Beaver-Pasquiset ground-water reservoir. }\end{array}$ \\
\hline & 1985 & WRIR 84-4254 & NA & $\begin{array}{l}\text { Effects of various ground-water-development } \\
\text { alternatives discussed. For Chipuxet ground-water } \\
\text { reservoir. }\end{array}$ \\
\hline \multirow[t]{8}{*}{ 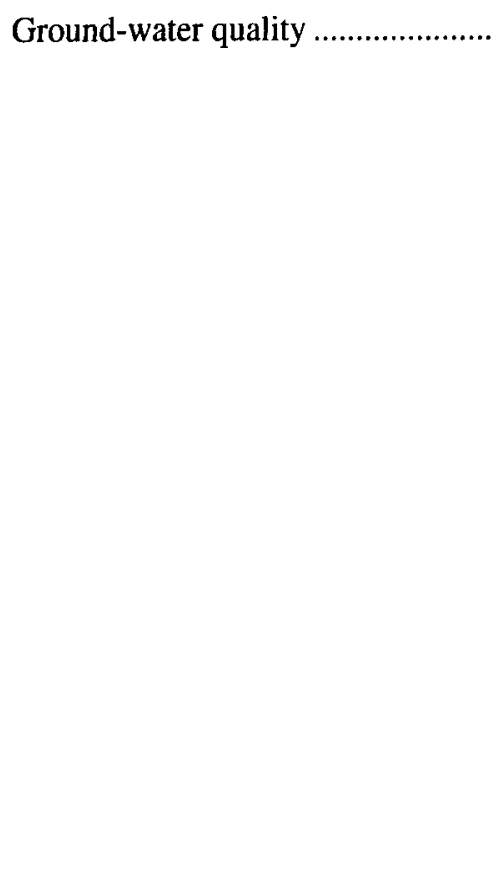 } & 1953 & GB 6 & $1: 122,000$ & $\begin{array}{l}\text { Major inorganic constituents, physical properties. For } 6 \\
\text { wells. Not on topographic base. }\end{array}$ \\
\hline & 1956 & GB 9 & $1: 31,680$ & $\begin{array}{l}\text { Major inorganic constituents, physical properties. For } \\
13 \text { wells. }\end{array}$ \\
\hline & 1963 & GB 13 & $1: 24,000$ & $\begin{array}{l}\text { Major inorganic constituents, physical properties. For } \\
\text { approximately } 20 \text { wells. For Upper Pawcatuck Basin. }\end{array}$ \\
\hline & 1966 & WSP 1821 & $1: 24,000$ & $\begin{array}{l}\text { Major inorganic constituents, physical properties. For } \\
17 \text { wells. For Upper Pawcatuck Basin. }\end{array}$ \\
\hline & 1976 & WISR 2 & $1: 12,000$ & $\begin{array}{l}\text { Major inorganic constituents, physical properties. For } \\
60 \text { wells. For Chipuxet Basin. }\end{array}$ \\
\hline & 1977 & WISR 3 & $1: 12,000$ & $\begin{array}{l}\text { Major inorganic constituents, physical properties, } \\
\text { nutrients. For a few wells. For Beaver-Pasquiset } \\
\text { Basin. }\end{array}$ \\
\hline & 1977 & OFR $77-561$ & NA & $\begin{array}{l}\text { Major inorganic constituents and physical properties for } \\
15 \text { wells; data collected 1973-75. Manganese data for } \\
3 \text { public-supply wells, 1960-75. Iron and manganese } \\
\text { content of sediment samples from aquifer; from } 4 \\
\text { wells; data collected 1974. For Chipuxet Basin. }\end{array}$ \\
\hline & 1985 & WRIR 84-4254 & NA & $\begin{array}{l}\text { Summary of major inorganic constituents, physical } \\
\text { properties, detergents. Values for nitrate at } 1 \text { aquifer- } \\
\text { test site. For Chipuxet Basin. }\end{array}$ \\
\hline
\end{tabular}


Table 22. Geologic and hydrologic information for the Mystic Quadrangle

\begin{tabular}{|c|c|c|c|c|}
\hline Information & Date & Publication & Scale & Remarks \\
\hline 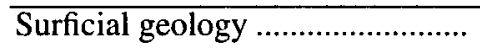 & 1971 & GQ 940 & $1: 24,000$ & Detailed surficial map. \\
\hline \multirow[t]{2}{*}{ 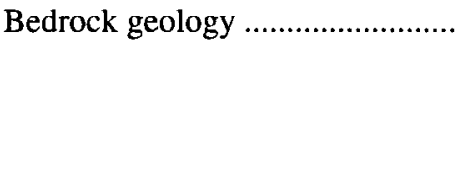 } & 1971 & В 1295 & $1: 125,000$ & Bedrock geologic map of Rhode Island. \\
\hline & 1975 & OFR $75-602$ & $1: 24,000$ & $\begin{array}{l}\text { Preliminary bedrock map. Handwritten information on } \\
\text { topographic base. No bedrock information for Rhode } \\
\text { Island part of quadrangle. }\end{array}$ \\
\hline Subsurface materials ........................ & 1953 & GB 6 & $1: 122,000$ & Lithologic log for 1 well. Not on topographic base. \\
\hline
\end{tabular}

Table 23. Geologic and hydrologic information for the Narragansett Pier Quadrangle

\begin{tabular}{|c|c|c|c|c|}
\hline Information & Date & Publication & Scale & Remarks \\
\hline \multirow[t]{2}{*}{ Surficial geology .............................. } & 1959 & GWM 5 & $1: 24,000$ & Till, stratified drift, and mixed deposits. \\
\hline & 1961 & GQ 140 & $1: 24,000$ & Detailed surficial map. Geology mapped in 1955-56. \\
\hline \multirow[t]{2}{*}{ Bedrock geology . } & 1956 & GQ 91 & $1: 31,680$ & Detailed bedrock map. Geology mapped in 1953. \\
\hline & 1971 & B 1295 & $1: 125,000$ & Bedrock geologic map of Rhode Island. \\
\hline \multirow[t]{2}{*}{ Subsurface materials .. } & 1953 & GB 6 & $1: 122,000$ & $\begin{array}{l}\text { Records of wells and test borings show principal aquifer. } \\
\text { Lithologic logs for } 15 \text { wells. Not on topographic base. }\end{array}$ \\
\hline & 1960 & HB 3 & $1: 148,000$ & Lithologic $\log$ for 1 well. \\
\hline \multirow[t]{2}{*}{ Altitude of bedrock surface ........... } & 1953 & GB 6 & $1: 122,000$ & $\begin{array}{l}\text { Records of wells and test borings give land-surface } \\
\text { altitude and depth to bedrock. Not on topographic } \\
\text { base. }\end{array}$ \\
\hline & 1959 & GWM 5 & $1: 24,000$ & $\begin{array}{l}\text { Approximate bedrock contours in stratified drift and } \\
\text { mixed deposits, } 50 \mathrm{ft} \text { interval. Altitude of bedrock } \\
\text { surface shown at well locations. }\end{array}$ \\
\hline \multirow[t]{2}{*}{ 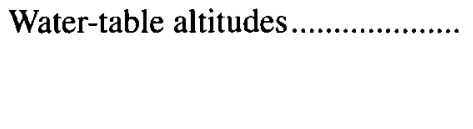 } & 1953 & GB 6 & $1: 122,000$ & $\begin{array}{l}\text { Well records give land-surface altitude and depth to } \\
\text { water. Not on topographic base. }\end{array}$ \\
\hline & 1959 & GWM 5 & $1: 24,000$ & Water-table altitudes shown at wells locations. \\
\hline 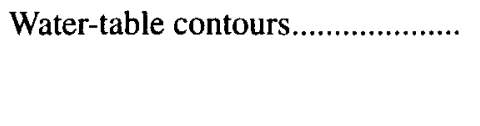 & 1959 & GWM 5 & $1: 24,000$ & $\begin{array}{l}\text { Approximate water-table contours in stratified drift and } \\
\text { mixed deposits, } 10 \text { and } 20 \mathrm{ft} \text { intervals. Data on wells } \\
\text { collected chiefly in } 1955 .\end{array}$ \\
\hline 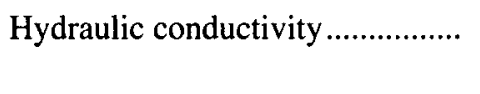 & 1960 & HB 3 & $1: 148,000$ & $\begin{array}{l}\text { Computed from aquifer test on } 1 \text { well. Shown in } \\
\mathrm{gal} / \mathrm{d} / \mathrm{ft}^{2} \text {. }\end{array}$ \\
\hline Transmissivity .................................... & 1960 & HB 3 & $1: 148,000$ & Computed from aquifer test on 1 well. Shown in $\mathrm{gal} / \mathrm{d} / \mathrm{ft}$. \\
\hline Drainage divides................................ & 1990 & WRIR 89-4164 & $1: 125,000$ & For small coastal basins. Not on topographic base. \\
\hline 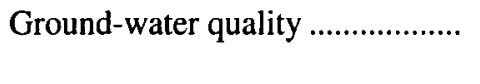 & 1953 & GB 6 & $1: 122,000$ & $\begin{array}{l}\text { Major inorganic constituents, physical properties. For } 1 \\
\text { well. Not on topographic base. }\end{array}$ \\
\hline
\end{tabular}


Table 24. Geologic and hydrologic information for the Newport Quadrangle

\begin{tabular}{|c|c|c|c|c|}
\hline Information & Date & Publication & Scale & Remarks \\
\hline Surficial geology .............................. & 1964 & GWM 20 & $1: 24,000$ & $\begin{array}{l}\text { Till and stratified-drift deposits. Not on topographic } \\
\text { base. }\end{array}$ \\
\hline \multirow[t]{3}{*}{ 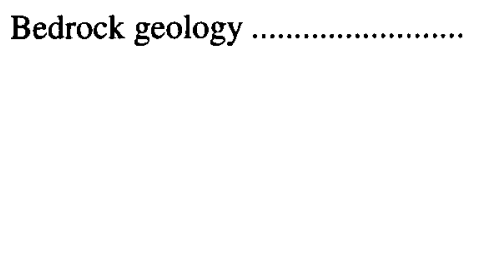 } & 1964 & GWM 20 & $1: 24,000$ & $\begin{array}{l}\text { Approximate contact between Pennsylvanian and pre- } \\
\text { Pennsylvanian bedrock shown. Not on topographic } \\
\text { base. }\end{array}$ \\
\hline & 1971 & B 1295 & $1: 125,000$ & Bedrock geologic map of Rhode Island. \\
\hline & 1975 & OFR 75-562 & $1: 24,000$ & $\begin{array}{l}\text { Preliminary bedrock map. Handwritten information on } \\
\text { topographic base. }\end{array}$ \\
\hline Subsurface materials ......................... & 1953 & GB 6 & $1: 122,000$ & $\begin{array}{l}\text { Records of wells and test borings show principal aquifer. } \\
\text { Not on topographic base. }\end{array}$ \\
\hline \multirow[t]{2}{*}{ Altitude of bedrock surface ........... } & 1953 & GB 6 & $1: 122,000$ & $\begin{array}{l}\text { Records of wells and test borings give land-surface } \\
\text { altitude and depth to bedrock. Not on topographic } \\
\text { base. }\end{array}$ \\
\hline & 1964 & GWM 20 & $1: 24,000$ & $\begin{array}{l}\text { Bedrock outcrops shown. Depth to bedrock shown at } \\
\text { well locations. Not on topographic base. }\end{array}$ \\
\hline \multirow[t]{2}{*}{ 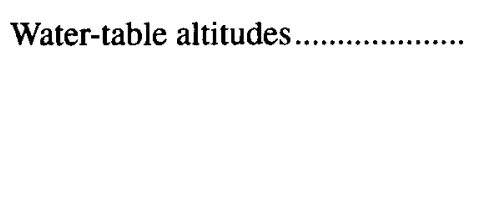 } & 1953 & GB 6 & $1: 122,000$ & $\begin{array}{l}\text { Well records give land surface-altitude and depth to } \\
\text { water. Not on topographic base. }\end{array}$ \\
\hline & 1964 & GWM 20 & $1: 24,000$ & $\begin{array}{l}\text { Depth to water shown at well locations. Not on } \\
\text { topographic base. Data on wells collected chiefly in } \\
1949 \text { and } 1963 \text {. }\end{array}$ \\
\hline Saturated thickness ............................ & 1964 & GWM 20 & $1: 24,000$ & $\begin{array}{l}\text { Can be estimated from depth to bedrock and depth to } \\
\text { water at some well locations. Not on topographic base. } \\
\text { Data on wells collected chiefly in } 1949 \text { and } 1963 \text {. }\end{array}$ \\
\hline Drainage divides................................. & 1990 & WRIR 89-4164 & $1: 125,000$ & For small coastal basins. Not on topographic base. \\
\hline \multirow[t]{2}{*}{ 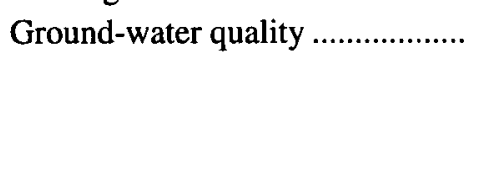 } & 1953 & GB 6 & $1: 122,000$ & $\begin{array}{l}\text { Major inorganic constituents, physical properties. For } 2 \\
\text { wells. Not on topographic base. }\end{array}$ \\
\hline & 1964 & GWM 20 & $1: 24,000$ & $\begin{array}{l}\text { Shows wells that yield salty water or water with high } \\
\text { iron content. Not on topographic base. }\end{array}$ \\
\hline
\end{tabular}


Table 25. Geologic and hydrologic information for the North Scituate Quadrangle

\begin{tabular}{|c|c|c|c|c|}
\hline Information & Date & Publication & Scale & Remarks \\
\hline \multirow[t]{3}{*}{ Surficial geology .............................. } & 1960 & GWM 12 & $1: 24,000$ & Till and stratified-drift deposits. \\
\hline & 1961 & GQ 143 & $1: 24,000$ & Detailed surficial map. Geology mapped in 1958. \\
\hline & 1961 & WSP 1499-A & $1: 125,000$ & $\begin{array}{l}\text { Till and stratified-drift deposits. For northeastern Rhode } \\
\text { Island. }\end{array}$ \\
\hline \multirow[t]{3}{*}{ 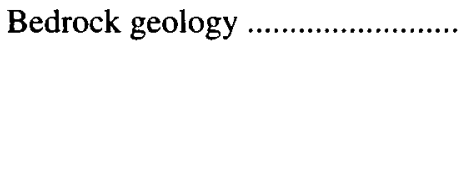 } & 1951 & GQ 13 & $1: 31,680$ & Detailed bedrock map. Geology mapped in $1946-47$. \\
\hline & 1961 & WSP 1499-A & $1: 362,100$ & $\begin{array}{l}\text { Generalized bedrock map shows Pennsylvanian/pre- } \\
\text { Pennsylvanian contact. }\end{array}$ \\
\hline & 1971 & B 1295 & $1: 125,000$ & Bedrock geologic map of Rhode Island. \\
\hline \multirow[t]{3}{*}{ 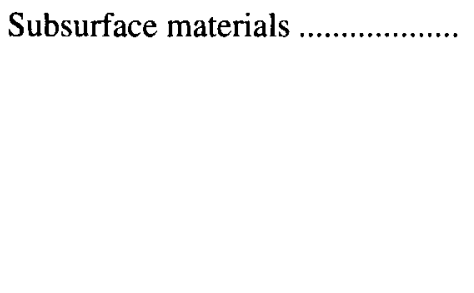 } & 1953 & GB 6 & $1: 122,000$ & $\begin{array}{l}\text { Records of wells and test borings show principal aquifer. } \\
\text { Lithologic log for } 1 \text { well. Not on topographic base. }\end{array}$ \\
\hline & 1961 & WSP 1499-A & $1: 125,000$ & $\begin{array}{l}\text { Shows thickness of stratified-drift deposits in ranges of } \\
<50,50-100 \text {, and }>100 \mathrm{ft} \text {. For northeastern Rhode } \\
\text { Island. }\end{array}$ \\
\hline & 1961 & GB 11 & $1: 62,400$ & $\begin{array}{l}\text { Shows stratified-drift deposits } 0-50 \mathrm{ft} \text { thick. Not on } \\
\text { topgraphic base. }\end{array}$ \\
\hline \multirow[t]{2}{*}{ Altitude of bedrock surface ........... } & 1953 & GB 6 & $1: 122,000$ & $\begin{array}{l}\text { Records of wells and test borings give land-surface } \\
\text { altitude and depth to bedrock. Not on topographic } \\
\text { base. }\end{array}$ \\
\hline & 1960 & GWM 12 & $1: 24,000$ & $\begin{array}{l}\text { Approximate bedrock contours in stratified drift, } 50 \mathrm{ft} \\
\text { interval. Altitude of bedrock surface shown at well } \\
\text { locations. Bedrock outcrops shown in stratified drift. }\end{array}$ \\
\hline \multirow[t]{2}{*}{ Water-table altitudes.......................... } & 1953 & GB 6 & $1: 122,000$ & $\begin{array}{l}\text { Well records give land-surface altitude and depth to } \\
\text { water. Not on topographic base. }\end{array}$ \\
\hline & 1960 & GWM 12 & $1: 24,000$ & $\begin{array}{l}\text { Water-table altitudes shown at well locations. Data on } \\
\text { wells collected chiefly in } 1958 .\end{array}$ \\
\hline Water-table contours...................... & 1960 & GWM 12 & $1: 24,000$ & $\begin{array}{l}\text { Approximate water-table contours in stratified drift, } 20 \mathrm{ft} \\
\text { interval. Data on wells collected chiefly in } 1958 .\end{array}$ \\
\hline \multirow[t]{2}{*}{ 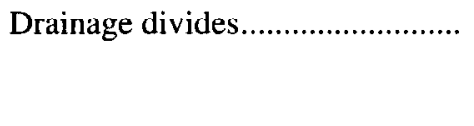 } & 1966 & HB 6 & $1: 24,000$ & For South Branch Pawtuxet Basin. \\
\hline & 1990 & WRIR 89-4164 & $1: 125,000$ & $\begin{array}{l}\text { For Woonasquatucket, Pocasset, and North Branch } \\
\text { Pawtuxet Basins. Not on topographic base. }\end{array}$ \\
\hline Ground-water quality ...................... & 1953 & GB 6 & $1: 122,000$ & $\begin{array}{l}\text { Major inorganic constituents, physical properties. For } \\
1 \text { well. Not on topographic base. }\end{array}$ \\
\hline
\end{tabular}


Table 26. Geologic and hydrologic information for the Oneco Quadrangle

\begin{tabular}{|c|c|c|c|c|}
\hline Information & Date & Publication & Scale & Remarks \\
\hline \multirow[t]{4}{*}{ 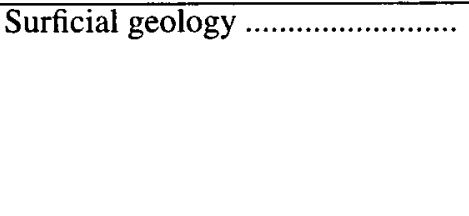 } & 1960 & GWM 10 & $1: 24,000$ & Till and stratified-drift deposits. \\
\hline & 1971 & GQ 917 & $1: 24,000$ & $\begin{array}{l}\text { Detailed surficial map. Geology mapped in } 1963 \text { and } \\
1968 .\end{array}$ \\
\hline & 1989 & WISR 5 & $1: 24,000$ & Till and stratified-drift deposits. For Upper Wood Basin. \\
\hline & 1993 & WRIR 92-4119 & $1: 68,700$ & Till and stratified-drift deposits. For Upper Wood Basin. \\
\hline \multirow[t]{2}{*}{ 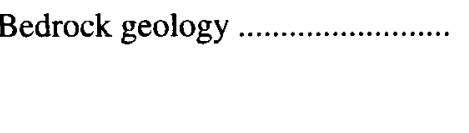 } & 1971 & GQ 930 & $1: 24,000$ & $\begin{array}{l}\text { Detailed bedrock map. Geology mapped in } 1962-63 \text { and } \\
1967-68 \text {. }\end{array}$ \\
\hline & 1971 & B 1295 & $1: 125,000$ & Bedrock geologic map of Rhode Island. \\
\hline \multirow[t]{3}{*}{ Subsurface materials ..................... } & 1953 & GB 6 & $1: 122,000$ & $\begin{array}{l}\text { Records of wells and test borings show principal aquifer. } \\
\text { Not on topographic base. }\end{array}$ \\
\hline & 1961 & GB 11 & $1: 61,400$ & $\begin{array}{l}\text { Shows stratified-drift deposits } 0-50 \mathrm{ft} \text { thick for part of } \\
\text { quadrangle. Not on topographic base. }\end{array}$ \\
\hline & 1989 & WISR 5 & $1: 24,000$ & $\begin{array}{l}\text { Records of wells and test holes show principal water- } \\
\text { bearing material for approximately } 20 \text { wells. } \\
\text { Lithologic logs for } 2 \text { wells. For Upper Wood Basin. }\end{array}$ \\
\hline \multirow[t]{4}{*}{ Altitude of bedrock surface ........... } & 1953 & GB 6 & $1: 122,000$ & $\begin{array}{l}\text { Records of wells and test borings give land-surface } \\
\text { altitude and depth to bedrock. Not on topographic } \\
\text { base. }\end{array}$ \\
\hline & 1960 & GWM 10 & $1: 24,000$ & $\begin{array}{l}\text { Approximate bedrock contours in stratified drift, } 50 \mathrm{ft} \\
\text { interval. Altitude of bedrock surface shown at well } \\
\text { locations. Bedrock outcrops in stratified drift shown. }\end{array}$ \\
\hline & 1974 & WSP 2033 & $1: 48,000$ & $\begin{array}{l}\text { Approximate bedrock contours, } 50 \mathrm{ft} \text { interval. For Lower } \\
\text { Pawcatuck Basin. }\end{array}$ \\
\hline & 1989 & WISR 5 & $1: 24,000$ & $\begin{array}{l}\text { Records of wells and test holes give land-surface altitude } \\
\text { and depth to bedrock. For } 3 \text { wells. For Upper Wood } \\
\text { Basin. }\end{array}$ \\
\hline \multirow[t]{3}{*}{ 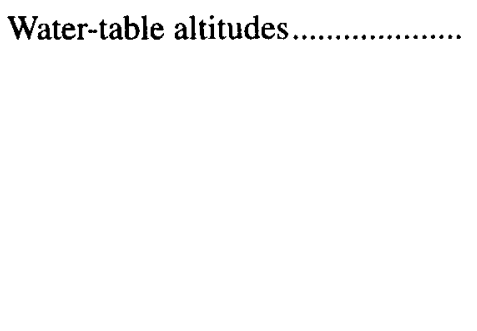 } & 1953 & GB 6 & $1: 122,000$ & $\begin{array}{l}\text { Well records give land-surface altitude and depth to } \\
\text { water. Not on topographic base. }\end{array}$ \\
\hline & 1960 & GWM 10 & $1: 24,000$ & $\begin{array}{l}\text { Water-table altitudes shown at well locations. Data on } \\
\text { wells and tcst borings collected chiefly in } 1960 .\end{array}$ \\
\hline & 1989 & WISR 5 & $1: 24,000$ & $\begin{array}{l}\text { Records of wells and test holes give land-surface altitude } \\
\text { and depth to water. For } 10 \text { wells. Water-level records } \\
\text { for } 1 \text { observation well; data collected 1969-88. For } \\
\text { Upper Wood Basin. }\end{array}$ \\
\hline \multirow[t]{2}{*}{ 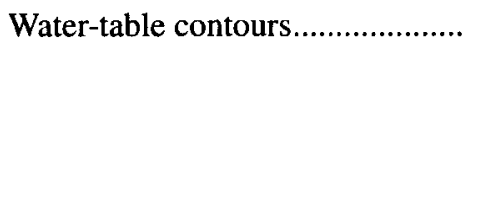 } & 1960 & GWM 10 & $1: 24,000$ & $\begin{array}{l}\text { Approximate water-table contours in stratified drift, } 20 \mathrm{ft} \\
\text { interval. Data on wells and test borings collected } \\
\text { chiefly in } 1960 .\end{array}$ \\
\hline & 1974 & WSP 2033 & $1: 48,000$ & $\begin{array}{l}\text { Water-table contours in stratified drift, } 10 \mathrm{ft} \text { interval. For } \\
\text { Lower Pawcatuck Basin. }\end{array}$ \\
\hline Saturated thickness......................... & 1974 & WSP 2033 & $1: 48,000$ & $\begin{array}{l}\text { Lines of equal saturated thickness, } 20 \mathrm{ft} \text { interval. For } \\
\text { Lower Pawcatuck Basin. }\end{array}$ \\
\hline 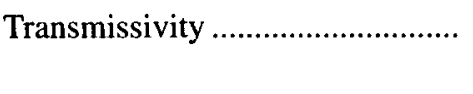 & 1974 & WSP 2033 & $1: 48,000$ & $\begin{array}{l}\text { Lines of equal transmissivity, interval of } 2,500 \mathrm{ft}^{2} / \mathrm{d} \text {. For } \\
\text { Lower Pawcatuck Basin. }\end{array}$ \\
\hline \multirow[t]{3}{*}{ 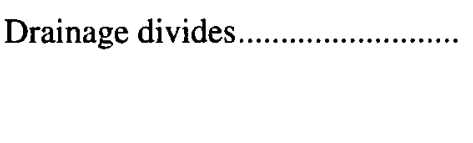 } & 1974 & WSP 2033 & $1: 48,000$ & For Lower Pawcatuck Basin. \\
\hline & 1989 & WISR 5 & $1: 24,000$ & For Upper Wood Basin. \\
\hline & 1993 & WRIR 92-4119 & $1: 68,700$ & For Upper Wood Basin. \\
\hline \multirow[t]{2}{*}{ Ground-water quality ...................... } & 1953 & GB 6 & $1: 122,000$ & $\begin{array}{l}\text { Major inorganic constituents, physical properties. For } 1 \\
\text { well. Not on topographic base. }\end{array}$ \\
\hline & 1974 & WSP 2033 & $1: 48,000$ & $\begin{array}{l}\text { Major inorganic constituents, physical properties. For } 1 \\
\text { well. Not on topographic base. }\end{array}$ \\
\hline
\end{tabular}


Table 27. Geologic and hydrologic information for the Oxford Quadrangle

\begin{tabular}{|c|c|c|c|c|}
\hline Information & Datc & Publication & Scale & Remarks \\
\hline \multirow[t]{2}{*}{ Surficial geology ............................. } & 1961 & GB 12 & $1: 24,800$ & $\begin{array}{l}\text { Till areas. For Wallum Lake study area. Not on } \\
\text { topographic base. }\end{array}$ \\
\hline & 1962 & GWM 19 & $1: 24,000$ & $\begin{array}{l}\text { Till and bedrock areas. For Rhode Island part of } \\
\text { quadrangle. }\end{array}$ \\
\hline \multirow[t]{2}{*}{ Bedrock geology ............................. } & 1971 & B 1295 & $1: 125,000$ & Bedrock geologic map of Rhode Island. \\
\hline & 1976 & OFR 76-622 & $1: 24,000$ & $\begin{array}{l}\text { Preliminary bedrock map. Handwritten information on } \\
\text { topographic base. }\end{array}$ \\
\hline Altitude of bedrock surface .......... & 1962 & GWM 19 & $1: 24,000$ & Altitude of bedrock shown for 2 wells. \\
\hline 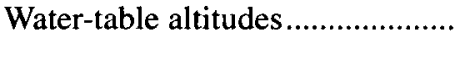 & 1962 & GWM 19 & $1: 24,000$ & $\begin{array}{l}\text { Water-table altitudes shown for } 2 \text { wells. Data on wells } \\
\text { collected chiefly in } 1961 \text {. }\end{array}$ \\
\hline \multirow[t]{3}{*}{ 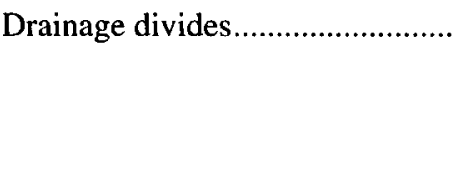 } & 1961 & GB 12 & $1: 24,800$ & $\begin{array}{l}\text { For subbasin of Quinebaug Basin. Not on topographic } \\
\text { base. }\end{array}$ \\
\hline & 1974 & WRIR 18-74 & $1: 24,000$ & For Branch Basin and subbasins. \\
\hline & 1990 & WRIR 89-4164 & $1: 125,000$ & For Blackstone Basin. Not on topographic base. \\
\hline
\end{tabular}


Table 28. Geologic and hydrologic information for the Pawtucket Quadrangle

\begin{tabular}{|c|c|c|c|c|}
\hline Information & Date & Publication & Scale & Remarks \\
\hline \multirow[t]{6}{*}{ Surficial geology ................................ } & 1948 & GB 3 & $1: 31,680$ & $\begin{array}{l}\text { Detailed surficial map. Geology mapped 1945-46. Till } \\
\text { and stratified-drift deposits on plate with well } \\
\text { locations. }\end{array}$ \\
\hline & 1949 & GQ 2 & $1: 31,680$ & Detailed surficial map. Geology mapped 1945-46. \\
\hline & 1950 & GB 5 & $1: 15,700$ & $\begin{array}{l}\text { Till and stratified-drift deposits. For the city of } \\
\text { Woonsocket. }\end{array}$ \\
\hline & 1961 & WSP 1499-A & $1: 125,000$ & $\begin{array}{l}\text { Till and stratified-drift deposits. For northeastern Rhode } \\
\text { Island. }\end{array}$ \\
\hline & 1974 & HB 7 & $1: 24,000$ & $\begin{array}{l}\text { Till and stratified-drift deposits. For Blackstone, } \\
\text { Moshassuck, and Abbott Run Basins. }\end{array}$ \\
\hline & 1985 & RAR 1 & $1: 24,000$ & $\begin{array}{l}\text { Till and stratified-drift deposits. For Blackstone and } \\
\text { Moshassuck Basins. }\end{array}$ \\
\hline \multirow[t]{5}{*}{ 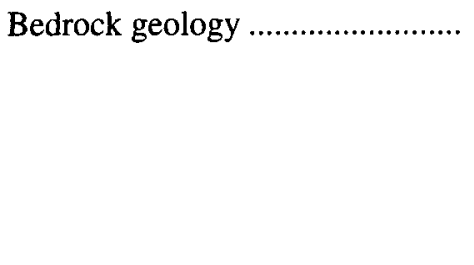 } & 1948 & GB 3 & $1: 31,680$ & Detailed bedrock map. Geology mapped 1945-46. \\
\hline & 1949 & GQ 1 & $1: 31,680$ & Detailed bedrock map. Geology mapped 1945-46. \\
\hline & 1950 & GB 5 & $1: 15,700$ & Detailed bedrock map. For the city of Woonsocket. \\
\hline & 1961 & WSP 1499-A & $1: 362,100$ & $\begin{array}{l}\text { Generalized bedrock map shows Pennsylvanian/pre- } \\
\text { Pennsylvanian contact. For northeastern Rhode Island. }\end{array}$ \\
\hline & 1971 & B 1295 & $1: 125,000$ & Bedrock geologic map of Rhode Island. \\
\hline \multirow[t]{8}{*}{ Subsurface materials ...................... } & 1948 & GB 3 & $1: 31,680$ & $\begin{array}{l}\text { Records of wells show materials penetrated for } \\
\text { approximately } 300 \text { wells. Lithologic logs for } 23 \text { wells. }\end{array}$ \\
\hline & 1950 & GB 5 & $1: 15,700$ & $\begin{array}{l}\text { Records of wells give materials penetrated for } 4 \text { wells. } \\
\text { For the city of Woonsocket. }\end{array}$ \\
\hline & 1953 & GB 6 & $1: 122,000$ & $\begin{array}{l}\text { Records of wells and test borings show principal aquifer. } \\
\text { Lithologic logs for } 6 \text { wells. Not on topographic base. }\end{array}$ \\
\hline & 1960 & HB 3 & $1: 148,000$ & Lithologic logs for 3 wells. \\
\hline & 1961 & WSP 1499-A & $1: 125,000$ & $\begin{array}{l}\text { Shows thickness of stratified-drift deposits in ranges of } \\
<50,50-100 \text {, and }>100 \mathrm{ft} \text {. For northeastern Rhode } \\
\text { Island. }\end{array}$ \\
\hline & 1961 & GB 11 & $1: 62,400$ & $\begin{array}{l}\text { Shows thickness of stratified-drift deposits in ranges of } \\
0-50,50-100 \text {, and } \geq 100 \mathrm{ft} \text {. Not on topographic base. }\end{array}$ \\
\hline & 1974 & HB 7 & $1: 24,000$ & $\begin{array}{l}\text { Records of wells and test holes show water-bearing } \\
\text { materials for } 210 \text { wells. Lithologic logs for } 173 \text { wells. } \\
\text { For Blackstone, Moshassuck, and Abbott Run Basins. }\end{array}$ \\
\hline & 1974 & WRIR 4-74 & $1: 24,000$ & $\begin{array}{l}\text { Shows areas where substantial part of saturated zone is } \\
\text { composed of silt and clay. }\end{array}$ \\
\hline \multirow[t]{4}{*}{ Altitude of bedrock surface .......... } & 1948 & GB 3 & $1: 31,680$ & $\begin{array}{l}\text { Approximate bedrock contours in stratified drift, } 100 \mathrm{ft} \\
\text { interval. Altitude of bedrock surface shown at well } \\
\text { locations. Bedrock outcrops shown on surficial map. }\end{array}$ \\
\hline & 1950 & GB 5 & $1: 15,700$ & $\begin{array}{l}\text { Bedrock altitude given for } 3 \text { wells. Bedrock outcrops } \\
\text { shown. For the city of Woonsocket. }\end{array}$ \\
\hline & 1953 & GB 6 & $1: 122,000$ & $\begin{array}{l}\text { Records of wells and test borings give land-surface } \\
\text { altitude and depth to bedrock. Not on topographic } \\
\text { base. }\end{array}$ \\
\hline & 1974 & HB 7 & $1: 24,000$ & $\begin{array}{l}\text { Records of wells and test holes give land-surface altitude } \\
\text { and depth to bedrock for } 89 \text { wells. For Blackstone, } \\
\text { Moshassuck, and Abbott Run Basins. }\end{array}$ \\
\hline \multirow[t]{2}{*}{ 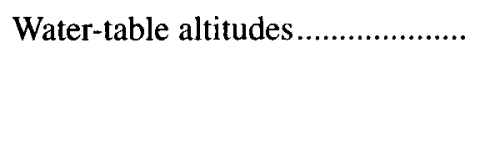 } & 1948 & GB 3 & $1: 31,680$ & $\begin{array}{l}\text { Well records give land-surface altitude and depth to } \\
\text { water for approximately } 275 \text { wells. }\end{array}$ \\
\hline & 1950 & GB 5 & $1: 15,700$ & $\begin{array}{l}\text { Well records give land-surface altitude and depth to } \\
\text { water for } 3 \text { wells. For the city of Woonsocket. }\end{array}$ \\
\hline
\end{tabular}


Table 28. Geologic and hydrologic information for the Pawtucket Quadrangle--Continued

\begin{tabular}{|c|c|c|c|c|}
\hline Information & Date & Publication & Scalc & Remarks \\
\hline \multirow[t]{2}{*}{ 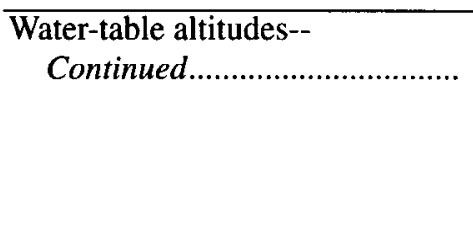 } & 1953 & GB 6 & $1: 122,000$ & $\begin{array}{l}\text { Well records give land-surface altitude and depth to } \\
\text { water. Not on topographic base. }\end{array}$ \\
\hline & 1974 & HB 7 & $1: 24,000$ & $\begin{array}{l}\text { Records of wells and test holes give land-surface altitude } \\
\text { and depth to water for } 212 \text { wells. For Blackstone, } \\
\text { Moshassuck, and Abbott Run Basins. }\end{array}$ \\
\hline Water-table contours........................... & 1985 & RAR 1 & $1: 24,000$ & $\begin{array}{l}\text { Water-table contours, } 10 \text { and } 20 \mathrm{ft} \text { intervals. For } \\
\text { Blackstone and Moshassuck Basins. }\end{array}$ \\
\hline 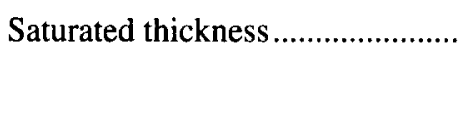 & 1974 & WRIR 4-74 & $1: 24,000$ & $\begin{array}{l}\text { Lines of equal saturated thickness; } 10,30 \text {, and } 40 \mathrm{ft} \\
\text { intervals. For Blackstone, Moshassuck, and } \Lambda \text { bbott } \\
\text { Run Basins and coastal areas. }\end{array}$ \\
\hline \multirow[t]{2}{*}{ 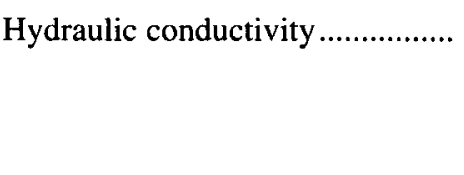 } & 1948 & GB 3 & $1: 31,680$ & $\begin{array}{l}\text { Computed from aquifer test on } 1 \text { well. Shown in } \\
\mathrm{gal} / \mathrm{d} / \mathrm{ft} 2 \text {. }\end{array}$ \\
\hline & 1960 & HB 3 & $1: 148,000$ & $\begin{array}{l}\text { Computed from aquifer tests on } 3 \text { wells. Shown in } \\
\text { gal } / \mathrm{d} / \mathrm{ft} 2 \text {. }\end{array}$ \\
\hline \multirow[t]{3}{*}{ Transmissivity . } & 1948 & GB 3 & $1: 31,680$ & Computed from aquifer test on 1 well. Shown in $\mathrm{gal} / \mathrm{d} / \mathrm{ft}$. \\
\hline & 1960 & HB 3 & $1: 148,000$ & $\begin{array}{l}\text { Computed from aquifer tests on } 3 \text { wells. Shown in } \\
\text { gal } / \mathrm{d} / \mathrm{ft} \text {. }\end{array}$ \\
\hline & 1974 & WRIR 4-74 & $1: 24,000$ & $\begin{array}{l}\text { Estimated from lithologic logs, aquifer tests, or specific } \\
\text { capacity data. Shown in intervals of } 4,000 \mathrm{ft}^{2} / \mathrm{d} \\
(30,000 \mathrm{gal} / \mathrm{d} / \mathrm{ft}) \text {. For Blackstone, Moshassuck, and } \\
\text { Abbott Run Basins and coastal areas. }\end{array}$ \\
\hline \multirow[t]{4}{*}{ Drainage divides................................ } & 1974 & HB 7 & $1: 24,000$ & For Blackstone and Moshassuck Basins. \\
\hline & 1974 & WRIR 4-74 & $1: 24,000$ & For Blackstone, Moshassuck, and Abbott Run Basins. \\
\hline & 1985 & RAR 1 & $1: 24,000$ & For Blackstone and Moshassuck Basins. \\
\hline & 1990 & WRIR 89-4164 & $1: 125,000$ & $\begin{array}{l}\text { For Blackstone, Abbott Run, Woonasquatucket, and } \\
\text { Moshassuck Basins. Not on topographic base. }\end{array}$ \\
\hline 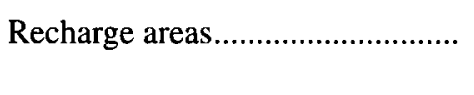 & 1985 & RAR 1 & $1: 24,000$ & $\begin{array}{l}\text { For Blackstone and Lower Blackstone-Moshassuck } \\
\text { ground-water reservoirs. }\end{array}$ \\
\hline \multirow[t]{2}{*}{ Ground-water reservoirs................ } & 1974 & WRIR 4-74 & $1: 24,000$ & $\begin{array}{l}\text { Yields estimated from mathematical models for } \\
\text { Blackstone, Lower Blackstone-Moshassuck, and } \\
\text { Abbott Run ground-water reservoirs. }\end{array}$ \\
\hline & 1985 & RAR 1 & $1: 24,000$ & $\begin{array}{l}\text { Shows Blackstone and Lower Blackstone-Moshassuck } \\
\text { ground-water reservoirs. }\end{array}$ \\
\hline 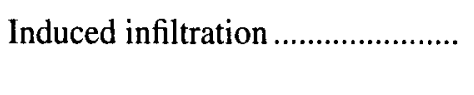 & 1974 & WRIR 4-74 & NA & $\begin{array}{l}\text { Streambed infiltration rates estimated for } 2 \text { sites on } \\
\text { Blackstone River. }\end{array}$ \\
\hline \multirow[t]{5}{*}{ 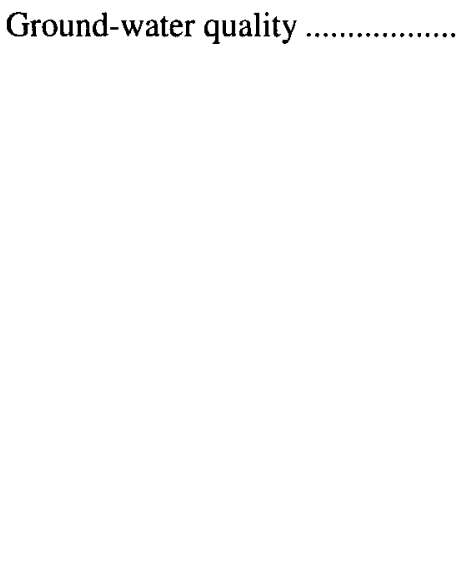 } & 1948 & GB 3 & $1: 31,680$ & $\begin{array}{l}\text { Major inorganic constituents, physical properties. For } 15 \\
\text { wells. Hardness for approximately } 50 \text { wells. }\end{array}$ \\
\hline & 1953 & GB 6 & $1: 122,000$ & $\begin{array}{l}\text { Major inorganic constituents, physical properties. For } 21 \\
\text { wells. Not on topographic base. }\end{array}$ \\
\hline & 1961 & WSP 1499-A & $1: 125,000$ & $\begin{array}{l}\text { Major inorganic constituents, physical properties. For } 8 \\
\text { wells. }\end{array}$ \\
\hline & 1974 & HB 7 & $1: 24,000$ & $\begin{array}{l}\text { Major inorganic constituents, physical properties. For } 51 \\
\text { wells. For Blackstone, Moshassuck, and Abbott Run } \\
\text { Basins. }\end{array}$ \\
\hline & 1974 & WRIR 4-74 & various & $\begin{array}{l}\text { Major inorganic constituents for } 4 \text { wells. Dissolved } \\
\text { solids, iron, and manganese trends for } 4 \text { wells. } \\
\text { Manganese, iron, pH, temperature, and specific } \\
\text { conductance for several wells. For Blackstone and } \\
\text { Abbott Run Basins. }\end{array}$ \\
\hline
\end{tabular}


Table 29. Geologic and hydrologic information for the Providence Quadrangle

\begin{tabular}{|c|c|c|c|c|}
\hline Information & Date & Publication & Scale & Remarks \\
\hline \multirow[t]{5}{*}{ Surficial geology ................................ } & 1956 & GQ 84 & $1: 31,680$ & Detailed surficial map. Geology mapped 1948 and 1952. \\
\hline & 1959 & GB 10 & $1: 31,680$ & Till and stratified-drift deposits. \\
\hline & 1961 & WSP 1499-A & $1: 125,000$ & Till and stratified-drift deposits. \\
\hline & 1974 & HB 7 & $1: 24,000$ & $\begin{array}{l}\text { Till and stratified-drift deposits. For Moshassuck Basin } \\
\text { and coastal areas. }\end{array}$ \\
\hline & 1985 & RAR 1 & $1: 24,000$ & $\begin{array}{l}\text { Till and stratified-drift deposits. For Moshassuck and } \\
\text { Lower Blackstone Basins. }\end{array}$ \\
\hline \multirow[t]{4}{*}{ 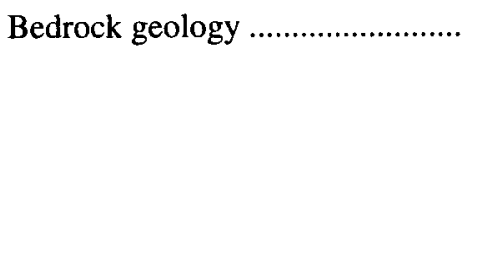 } & 1959 & GB 10 & $1: 31,680$ & $\begin{array}{l}\text { Approximate Pennsylvanian/pre-Pennsylvanian contact } \\
\text { shown. }\end{array}$ \\
\hline & 1959 & GQ 118 & $1: 24,000$ & Detailed bedrock map. Geology mapped 1952-57. \\
\hline & 1961 & WSP 1499-A & $1: 362,100$ & $\begin{array}{l}\text { Generalized bedrock map shows Pennsylvanian/pre- } \\
\text { Pennsylvanian contact. }\end{array}$ \\
\hline & 1971 & В 1295 & $1: 125,000$ & Bedrock geologic map of Rhode Island. \\
\hline \multirow[t]{9}{*}{ Subsurface materials ....................... } & 1945 & GB 1 & $\begin{array}{l}1: 31,680 \\
1: 14,400\end{array}$ & Lithologic logs for 67 wells and test borings. \\
\hline & 1945 & GB 2 & $\begin{array}{l}1: 31,680 \\
1: 14,400\end{array}$ & $\begin{array}{l}\text { Records of wells show geologic materials for } \\
\text { approximately } 200 \text { wells. Lithologic logs for } \\
\text { approximately } 150 \text { wells. }\end{array}$ \\
\hline & 1953 & GB 6 & $1: 122,000$ & $\begin{array}{l}\text { Records of wells and test borings show principal aquifer. } \\
\text { Lithologic logs for } 13 \text { wells. Not on topographic base. }\end{array}$ \\
\hline & 1959 & GB 10 & $1: 31,680$ & $\begin{array}{l}\text { Records of wells and test borings show water-bearing } \\
\text { materials. Lithologic logs for approximately } 130 \\
\text { wells. Generalized geologic sections. }\end{array}$ \\
\hline & 1960 & HB 3 & $1: 148,000$ & Lithologic logs for 5 wells. \\
\hline & 1961 & WSP 1499-A & $1: 125,000$ & $\begin{array}{l}\text { Shows thickness of stratified-drift deposits in ranges of } \\
<50,50-100 \text {, and }>100 \mathrm{ft} \text {. }\end{array}$ \\
\hline & 1961 & GB 11 & $1: 62,400$ & $\begin{array}{l}\text { Shows thickness of stratified-drift deposits in ranges of } \\
0-50,50-100, \text { and } \geq 100 \mathrm{ft} \text {. Not on topographic base. }\end{array}$ \\
\hline & 1974 & HB 7 & $1: 24,000$ & $\begin{array}{l}\text { Records of wells and test holes show water-bearing } \\
\text { materials for } 25 \text { wells. Lithologic logs for } 84 \text { wells. } \\
\text { For Moshassuck Basin and coastal areas. }\end{array}$ \\
\hline & 1974 & WRIR 4-74 & $1: 24,000$ & $\begin{array}{l}\text { Shows areas where substantial part of saturated zone is } \\
\text { composed of silt and clay. }\end{array}$ \\
\hline \multirow[t]{6}{*}{ Altitude of bedrock surface .......... } & 1945 & GB 1 & $1: 31,680$ & Approximate bedrock contours, $100 \mathrm{ft}$ interval. Altitude \\
\hline & & & $1: 14,400$ & $\begin{array}{l}\text { of bedrock surface shown at well locations. Seismic } \\
\text { survey lines shown. Bedrock altitudes for approximately } \\
160 \text { sites. }\end{array}$ \\
\hline & 1945 & GB 2 & $1: 31,680$ & $\begin{array}{l}\text { Approximate bedrock contours, } 100 \mathrm{ft} \text { interval. Altitude } \\
\text { of bedrock surface shown at well locations. Seismic } \\
\text { survey lines shown. }\end{array}$ \\
\hline & 1953 & GB 6 & $1: 122,000$ & $\begin{array}{l}\text { Records of wells and test borings give land-surface } \\
\text { altitude and depth to bedrock. Not on topographic } \\
\text { base. }\end{array}$ \\
\hline & 1959 & GB 10 & $1: 31,680$ & $\begin{array}{l}\text { Approximate bedrock contours in stratified drift, } 100 \mathrm{ft} \\
\text { interval. Altitude of bedrock surface shown at well } \\
\text { locations. Seismic sites shown. }\end{array}$ \\
\hline & 1974 & HB 7 & $1: 24,000$ & $\begin{array}{l}\text { Records of wells and test holes give land-surface } \\
\text { altitude and depth to bedrock for } 62 \text { wells. For } \\
\text { Moshassuck Basin and coastal areas. }\end{array}$ \\
\hline
\end{tabular}


Table 29. Geologic and hydrologic information for the Providence Quadrangle--Continued

\begin{tabular}{|c|c|c|c|c|}
\hline Information & Date & Publication & Scale & Remarks \\
\hline \multirow[t]{4}{*}{ Water-table altitudes ......................... } & 1945 & GB 2 & $\begin{array}{l}1: 31,680 \\
1: 14,400\end{array}$ & $\begin{array}{l}\text { Well records give depth to water for about } 75 \text { wells. } \\
\text { Land-surface altitudes for most sites given in well logs } \\
\text { or in GB } 1 \text {. }\end{array}$ \\
\hline & 1953 & GB 6 & $1: 122,000$ & $\begin{array}{l}\text { Well records give land-surface altitude and depth to } \\
\text { water. Not on topographic base. }\end{array}$ \\
\hline & 1959 & GB 10 & $1: 31,680$ & $\begin{array}{l}\text { Well records give land-surface altitude and depth to } \\
\text { water. }\end{array}$ \\
\hline & 1974 & HB 7 & $1: 24,000$ & $\begin{array}{l}\text { Records of wells and test holes give land-surface altitude } \\
\text { and depth to water for } 61 \text { wells. For Moshassuck } \\
\text { Basin and coastal areas. }\end{array}$ \\
\hline \multirow[t]{2}{*}{ Water-table contours....................... } & 1959 & GB 10 & $1: 31,680$ & $\begin{array}{l}\text { Water-table contours in stratified drift, } 10 \mathrm{ft} \text { interval. } \\
\text { Data collected in } 1956 . \text { Not on topographic base. }\end{array}$ \\
\hline & 1985 & RAR 1 & $1: 24,000$ & $\begin{array}{l}\text { Water-table contours, } 10 \text { and } 20 \mathrm{ft} \text { intervals. For } \\
\text { Moshassuck and Lower Blackstone Basins and coastal } \\
\text { areas. }\end{array}$ \\
\hline 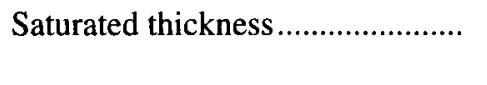 & 1974 & WRIR 4-74 & $1: 24,000$ & $\begin{array}{l}\text { Lines of equal saturated thickness; } 10,30 \text {, and } 40 \mathrm{ft} \\
\text { intervals. For Moshassuck Basin and coastal areas. }\end{array}$ \\
\hline \multirow[t]{2}{*}{ 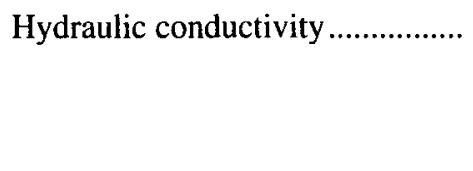 } & 1959 & GB 10 & $1: 31,680$ & $\begin{array}{l}\text { Computed from aquifer tests on } 5 \text { wells. Shown in } \\
\mathrm{gal} / \mathrm{d} / \mathrm{ft}^{2} \text {. }\end{array}$ \\
\hline & 1960 & HB 3 & $1: 148,000$ & $\begin{array}{l}\text { Computed from aquifer tests on } 5 \text { wells. Shown in } \\
\mathrm{gal} / \mathrm{d} / \mathrm{ft}^{2} \text {. }\end{array}$ \\
\hline \multirow[t]{4}{*}{ 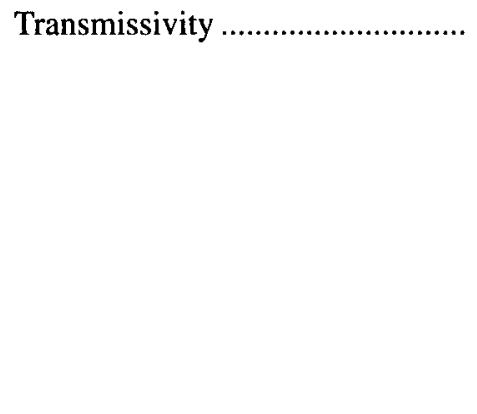 } & 1947 & SC 1 & NA & $\begin{array}{l}\text { Computed from aquifer-test data for } 1 \text { site. Shown in } \\
\mathrm{gal} / \mathrm{d} / \mathrm{ft} \text {. }\end{array}$ \\
\hline & 1959 & GB 10 & $1: 31,680$ & $\begin{array}{l}\text { Computed from aquifer tests on } 5 \text { wells. Shown in } \\
\mathrm{gal} / \mathrm{d} / \mathrm{ft} \text {. }\end{array}$ \\
\hline & 1960 & HB 3 & $1: 148,000$ & $\begin{array}{l}\text { Computed from aquifer tests on } 5 \text { wells. Shown in } \\
\mathrm{gal} / \mathrm{d} / \mathrm{ft} \text {. }\end{array}$ \\
\hline & 1974 & WRIR 4-74 & $1: 24,000$ & $\begin{array}{l}\text { Estimated from lithologic logs, aquifer tests, or specific } \\
\text { capacity data. Shown in intervals of } 4,000 \mathrm{ft}^{2} / \mathrm{d} \\
(30,000 \mathrm{gal} / \mathrm{d} / \mathrm{ft}) \text {. For Moshassuck Basin and coastal } \\
\text { areas. }\end{array}$ \\
\hline \multirow[t]{3}{*}{ 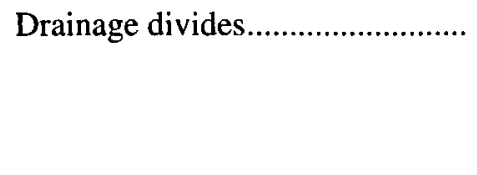 } & 1974 & WRIR 4-74 & $1: 24,000$ & For Moshassuck Basin. \\
\hline & 1985 & RAR 1 & $1: 24,000$ & For Moshassuck and Lower Blackstone Basins. \\
\hline & 1990 & WRIR 89-4164 & $1: 125,000$ & $\begin{array}{l}\text { For Moshassuck, Woonasquatucket, Pocasset, and } \\
\text { Pawtuxet Basins. Not on topographic base. }\end{array}$ \\
\hline 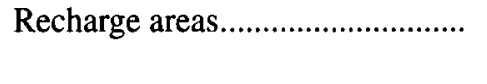 & 1985 & RAR 1 & $1: 24,000$ & $\begin{array}{l}\text { For Lower Blackstone-Moshassuck ground-water } \\
\text { reservoir. }\end{array}$ \\
\hline \multirow[t]{3}{*}{ Ground-water reservoirs................ } & 1947 & SC 1 & NA & $\begin{array}{l}\text { Aquifer-test data for } 1 \text { site. For Providence-Warwick } \\
\text { ground-water reservoir. }\end{array}$ \\
\hline & 1974 & WRIR 4-74 & $1: 24,000$ & $\begin{array}{l}\text { Yield estimated from mathematical models for Lower } \\
\text { Blackstone-Moshassuck ground-water reservoir. }\end{array}$ \\
\hline & 1985 & RAR 1 & $1: 24,000$ & $\begin{array}{l}\text { Shows Lower Blackstone-Moshassuck ground-water } \\
\text { reservoir. }\end{array}$ \\
\hline \multirow[t]{2}{*}{ 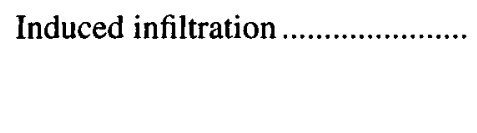 } & 1959 & GB 10 & NA & Discussed for Woonasquatucket and Pawtuxet Rivers. \\
\hline & 1974 & WRIR 4-74 & NA & $\begin{array}{l}\text { Streambed infiltration rate estimated for Moshassuck } \\
\text { River. }\end{array}$ \\
\hline \multirow[t]{2}{*}{ Ground-water quality ..................... } & 1945 & GB 1 & $\begin{array}{l}1: 31,680 \\
1: 14,400\end{array}$ & $\begin{array}{l}\text { Major inorganic constituents, physical properties. } \\
\text { For } 5 \text { wells. }\end{array}$ \\
\hline & 1945 & GB 2 & $\begin{array}{l}1: 31,680 \\
1: 14,400\end{array}$ & Well records give hardness for about 30 wells. \\
\hline
\end{tabular}


Table 29. Geologic and hydrologic information for the Providence Quadrangle--Continued

\begin{tabular}{|c|c|c|c|c|}
\hline Information & Date & Publication & Scale & Remarks \\
\hline \multirow[t]{4}{*}{ 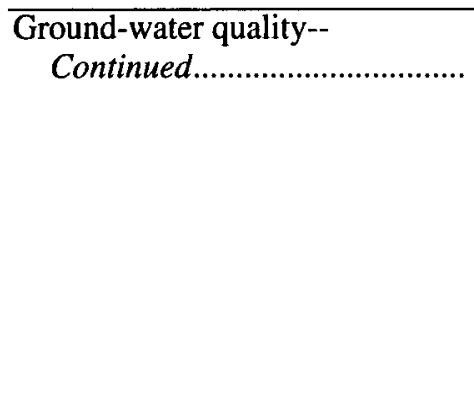 } & 1953 & GB 6 & $1: 122,000$ & $\begin{array}{l}\text { Major inorganic constituents, physical properties. For } 13 \\
\text { wells. Not on topographic base. }\end{array}$ \\
\hline & 1959 & GB 10 & $1: 31,680$ & $\begin{array}{l}\text { Major inorganic constituents, physical properties. For } 27 \\
\text { wells. Chloride concentrations for several additional } \\
\text { wells. Chloride fluctuations for } 3 \text { wells. }\end{array}$ \\
\hline & 1961 & WSP 1499-A & $1: 125,000$ & $\begin{array}{l}\text { Major inorganic constituents, physical properties. For } 7 \\
\text { wells. }\end{array}$ \\
\hline & 1974 & HB 7 & $1: 24,000$ & $\begin{array}{l}\text { Major inorganic constituents. For } 9 \text { wells. For } \\
\text { Moshassuck Basin and coastal areas. }\end{array}$ \\
\hline
\end{tabular}

Table 30. Geologic and hydrologic information for the Prudence Island Quadrangle

\begin{tabular}{|c|c|c|c|c|}
\hline Information & Date & Publication & Scale & Remarks \\
\hline Surficial geology ............................ & 1964 & GWM 20 & $1: 24,000$ & $\begin{array}{l}\text { Till and stratified-drift deposits. Not on topographic } \\
\text { base. }\end{array}$ \\
\hline \multirow[t]{2}{*}{ 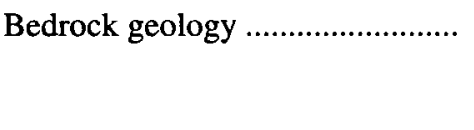 } & 1971 & B 1295 & $1: 125,000$ & Bedrock geologic map of Rhode Island. \\
\hline & 1975 & OFR 75-562 & $1: 24,000$ & $\begin{array}{l}\text { Preliminary bedrock map. Handwritten information on } \\
\text { topographic base. }\end{array}$ \\
\hline \multirow[t]{2}{*}{ 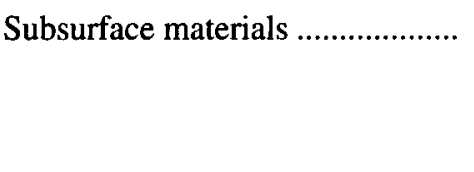 } & 1953 & GB 6 & $1: 122,000$ & $\begin{array}{l}\text { Records of wells and test borings show principal aquifer } \\
\text { Not on topographic base. }\end{array}$ \\
\hline & 1964 & GWM 20 & $1: 24,000$ & $\begin{array}{l}\text { Shows areas of till greater than } 50 \mathrm{ft} \text { thick. Not on } \\
\text { topographic base. }\end{array}$ \\
\hline \multirow[t]{2}{*}{ Altitude of bedrock surface .......... } & 1953 & GB 6 & $1: 122,000$ & $\begin{array}{l}\text { Records of wells and test borings give land-surface } \\
\text { altitude and depth to bedrock. Not on topographic } \\
\text { base. }\end{array}$ \\
\hline & 1964 & GWM 20 & $1: 24,000$ & $\begin{array}{l}\text { Bedrock outcrops shown. Depth to bedrock shown at } \\
\text { well locations. Not on topographic base. }\end{array}$ \\
\hline \multirow[t]{2}{*}{ Water-table altitudes............................ } & 1953 & GB 6 & $1: 122,000$ & $\begin{array}{l}\text { Well records give land-surface altitude and depth to } \\
\text { water. Not on topographic base. }\end{array}$ \\
\hline & 1964 & GWM 20 & $1: 24,000$ & $\begin{array}{l}\text { Depth to water shown at well locations. Not on } \\
\text { topographic base. Data on wells collected chiefly in } \\
1949 \text { and } 1963 \text {. }\end{array}$ \\
\hline 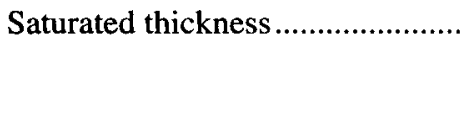 & 1964 & GWM 20 & $1: 24,000$ & $\begin{array}{l}\text { Can be estimated from depth to bedrock and depth to } \\
\text { water at some well locations. Not on topographic base } \\
\text { Data on wells collected chiefly in } 1949 \text { and } 1963 \text {. }\end{array}$ \\
\hline Drainage divides.............................. & 1990 & WRIR 89-4I64 & $1: 125,000$ & For small coastal basins. Not on topographic base. \\
\hline \multirow[t]{2}{*}{ 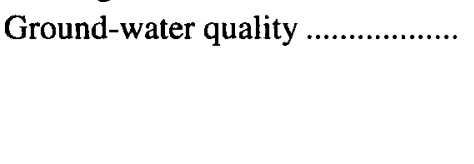 } & 1953 & GB 6 & $1: 122,000$ & $\begin{array}{l}\text { Major inorganic constituents, physical properties. For } 2 \\
\text { wells. Not on topographic base. }\end{array}$ \\
\hline & 1964 & GWM 20 & $1: 24,000$ & $\begin{array}{l}\text { Shows wells that yield water with high iron content and } \\
\text { wells that yield salty water. Not on topographic base. }\end{array}$ \\
\hline
\end{tabular}


Table 31. Geologic and hydrologic information for the Quonochontaug Quadrangle

\begin{tabular}{|c|c|c|c|c|}
\hline Information & Date & Publication & Scale & Remarks \\
\hline Surficial geology ............................. & 1960 & GWM 11 & $1: 24,000$ & Till, stratified drift, and mixed deposits. \\
\hline \multirow[t]{2}{*}{ Bedrock geology .............................. } & 1959 & GQ 117 & $1: 31,680$ & $\begin{array}{l}\text { Detailed bedrock map. Geology mapped in } 1953,1954 \text {, } \\
\text { and } 1956 .\end{array}$ \\
\hline & 1971 & B 1295 & $1: 125,000$ & Bedrock geologic map of Rhode Island. \\
\hline \multirow[t]{2}{*}{ Subsurface materials ....................... } & 1953 & GB 6 & $1: 122,000$ & $\begin{array}{l}\text { Records of wells and test borings show principal aquifer. } \\
\text { Lithologic logs for } 7 \text { wells. Not on topographic base. }\end{array}$ \\
\hline & 1961 & GB 11 & $1: 61,400$ & $\begin{array}{l}\text { Shows stratified-drift deposits } 0-50 \mathrm{ft} \text { thick. Not on } \\
\text { topographic base. }\end{array}$ \\
\hline \multirow[t]{3}{*}{ Altitude of bedrock surface .......... } & 1953 & GB 6 & $1: 122,000$ & $\begin{array}{l}\text { Records of wells and test borings give land-surface } \\
\text { altitude and depth to bedrock. Not on topographic } \\
\text { base. }\end{array}$ \\
\hline & 1960 & GWM 11 & $1: 24,000$ & $\begin{array}{l}\text { Approximate bedrock contours, } 50 \mathrm{ft} \text { interval. Nltitude } \\
\text { of bedrock surface shown at well locations. Bedrock } \\
\text { outcrops in stratified drift shown. }\end{array}$ \\
\hline & 1974 & WSP 2033 & $1: 48,000$ & $\begin{array}{l}\text { Approximate bedrock contours, } 50 \mathrm{ft} \text { interval. For Lower } \\
\text { Pawcatuck Basin. }\end{array}$ \\
\hline \multirow[t]{2}{*}{ Water-table altitudes ........................ } & 1953 & GB 6 & $1: 122,000$ & $\begin{array}{l}\text { Well records give land-surface altitude and depth to } \\
\text { water. Not on topographic base. }\end{array}$ \\
\hline & 1960 & GWM 11 & $1: 24,000$ & $\begin{array}{l}\text { Water-table altitudes shown at well locations. Data on } \\
\text { wells collected chiefly in } 1955 \text {. }\end{array}$ \\
\hline \multirow[t]{2}{*}{ Water-table contours........................... } & 1960 & GWM 11 & $1: 24,000$ & $\begin{array}{l}\text { Approximate water-table contours, } 10 \text { and } 20 \mathrm{ft} \\
\text { intervals. Data on wells collected chiefly in } 1955 \text {. }\end{array}$ \\
\hline & 1974 & WSP 2033 & $1: 48,000$ & $\begin{array}{l}\text { Water-table contours in stratified drift, } 10 \mathrm{ft} \text { interval. For } \\
\text { Lower Pawcatuck Basin. }\end{array}$ \\
\hline 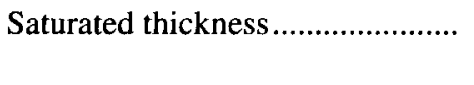 & 1974 & WSP 2033 & $1: 48,000$ & $\begin{array}{l}\text { Lines of equal saturated thickness, } 20 \mathrm{ft} \text { interval. For } \\
\text { Lower Pawcatuck Basin. }\end{array}$ \\
\hline Drainage divides................................ & 1974 & WSP 2033 & $1: 48,000$ & For Lower Pawcatuck Basin. \\
\hline
\end{tabular}


Table 32. Geologic and hydrologic information for the Sakonnet Point Quadrangle

\begin{tabular}{|c|c|c|c|c|}
\hline Information & Date & Publication & Scale & Remarks \\
\hline Surficial geology ............................ & 1964 & GWM 21 & $1: 24,000$ & $\begin{array}{l}\text { Till and stratified-drift deposits. Not on topographic } \\
\text { base. }\end{array}$ \\
\hline \multirow[t]{3}{*}{ 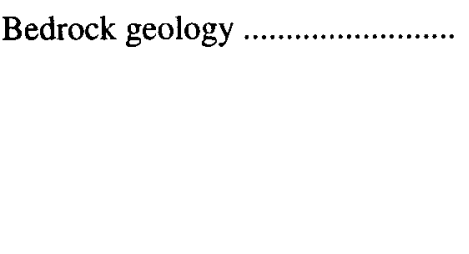 } & 1964 & GWM 21 & $1: 24,000$ & $\begin{array}{l}\text { Approximate contact between Pennsylvanian and pre- } \\
\text { Pennsylvanian bedrock. Not on topographic base. }\end{array}$ \\
\hline & 1971 & В 1295 & $1: 125,000$ & Bedrock geologic map of Rhode Island. \\
\hline & 1975 & OFR $75-562$ & $1: 24,000$ & $\begin{array}{l}\text { Preliminary bedrock map for northwest corner of } \\
\text { quadrangle. Handwritten information on topographic } \\
\text { base. }\end{array}$ \\
\hline \multirow[t]{2}{*}{ Subsurface materials ........................ } & 1953 & GB 6 & $1: 122,000$ & $\begin{array}{l}\text { Records of wells and test borings show principal aquifer. } \\
\text { Not on topographic base. }\end{array}$ \\
\hline & 1964 & GWM 21 & $1: 24,000$ & $\begin{array}{l}\text { Shows area of till greater than } 50 \mathrm{ft} \text { thick. Not on } \\
\text { topographic base. }\end{array}$ \\
\hline \multirow[t]{2}{*}{ Altitude of bedrock surface ........... } & 1953 & GB 6 & $1: 122,000$ & $\begin{array}{l}\text { Records of wells and test borings give land-surface } \\
\text { altitude and depth to bedrock. Not on topographic } \\
\text { base. }\end{array}$ \\
\hline & 1964 & GWM 21 & $1: 24,000$ & $\begin{array}{l}\text { Bedrock outcrops shown. Depth to bedrock shown at } \\
\text { well locations. Not on topographic base. }\end{array}$ \\
\hline \multirow[t]{2}{*}{ 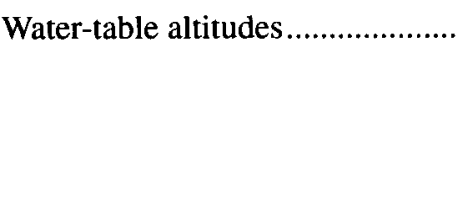 } & 1953 & GB 6 & $1: 122,000$ & $\begin{array}{l}\text { Well records give land-surface altitude and depth to } \\
\text { water. Not on topographic base. }\end{array}$ \\
\hline & 1964 & GWM 21 & $1: 24,000$ & $\begin{array}{l}\text { Depth to water shown at well locations. Not on } \\
\text { topographic base. Data on wells collected chiefly in } \\
1949 \text { and } 1963 \text {. }\end{array}$ \\
\hline Saturated thickness.............................. & 1964 & GWM 21 & $1: 24,000$ & $\begin{array}{l}\text { Can be estimated from depth to bedrock and depth to } \\
\text { water at some well locations. Not on topographic base. } \\
\text { Data on wells collected chiefly in } 1949 \text { and } 1963 \text {. }\end{array}$ \\
\hline Drainage divides............................. & 1990 & WRIR 89-4164 & $1: 125,000$ & For coastal areas. Not on topographic base. \\
\hline \multirow[t]{2}{*}{ 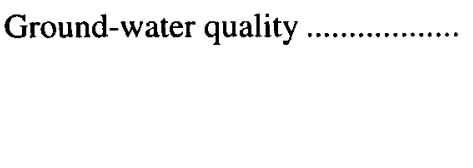 } & 1953 & GB 6 & $1: 122,000$ & $\begin{array}{l}\text { Major inorganic constituents, physical properties. For } 2 \\
\text { wells. Not on topographic base. }\end{array}$ \\
\hline & 1964 & GWM 21 & $1: 24,000$ & $\begin{array}{l}\text { Shows wells that yield water with high iron content and } \\
\text { wells that yield salty water. }\end{array}$ \\
\hline
\end{tabular}


Table 33. Geologic and hydrologic information for the Slocum Quadrangle

\begin{tabular}{|c|c|c|c|c|}
\hline Information & Date & Publication & Scale & Remarks \\
\hline \multirow[t]{9}{*}{ Surficial geology ............................... } & 1948 & SC 2 & $1: 53,400$ & $\begin{array}{l}\text { Till and stratified-drift deposits. For area near Exeter. } \\
\text { Not on topographic base. }\end{array}$ \\
\hline & 1957 & GQ 106 & $1: 31,680$ & Detailed surficial map. Geology mapped 1953-54. \\
\hline & 1959 & GWM 2 & $1: 24,000$ & Till, stratified drift, and mixed deposits. \\
\hline & 1966 & HB 6 & $1: 24,000$ & $\begin{array}{l}\text { Till and stratified-drift deposits. For the South Branch } \\
\text { Pawtuxet Basin. }\end{array}$ \\
\hline & 1966 & WSP 1821 & $1: 24,000$ & $\begin{array}{l}\text { Till, stratified drift, and mixed deposits. For Upper } \\
\text { Pawcatuck Basin. }\end{array}$ \\
\hline & 1976 & WISR 2 & $1: 12,000$ & Till and stratified-drift deposits. For Chipuxet Basin. \\
\hline & 1977 & WISR 3 & $1: 12,000$ & Till areas. For Beaver Basin. \\
\hline & $\mathrm{U}$ & RAR 2 & $1: 24,000$ & $\begin{array}{l}\text { Till and stratified-drift deposits. For Hunt and } \\
\text { Annaquatucket Basins. Unpublished report, available } \\
\text { at Rhode Island Subdistrict Office, U.S. Geological } \\
\text { Survey. }\end{array}$ \\
\hline & U & RAR 3 & $1: 24,000$ & $\begin{array}{l}\text { Till and stratified-drift deposits. For Chipuxet Basin. } \\
\text { Unpublished report, available at Rhode Island } \\
\text { Subdistrict Office, U.S. Geological Survey. }\end{array}$ \\
\hline \multirow[t]{2}{*}{ 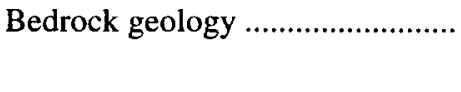 } & 1959 & GQ 114 & $1: 31,680$ & Detailed bedrock map. Geology mapped 1953-54. \\
\hline & 1971 & В 1295 & $1: 125,000$ & Bedrock geologic map of Rhode Island. \\
\hline \multirow[t]{9}{*}{ 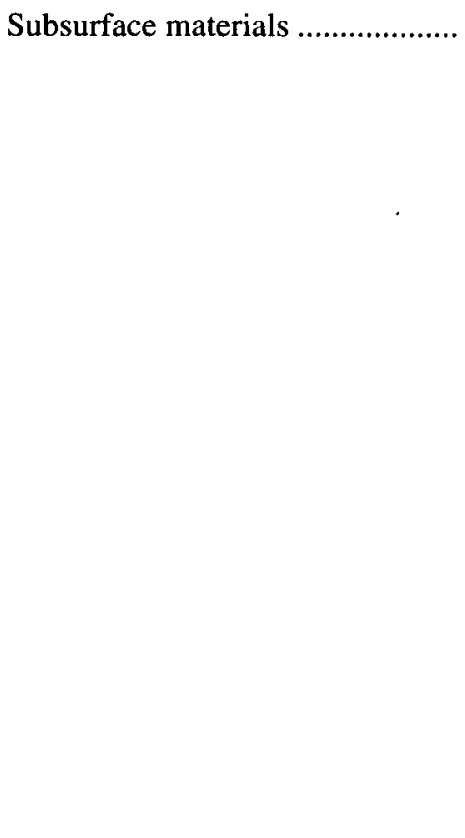 } & 1948 & SC 2 & $1: 53,400$ & $\begin{array}{l}\text { Generalized geologic sections. Records of wells show } \\
\text { materials penetrated for } 32 \text { wells. Lithologic logs for } 7 \\
\text { wells. Analyses of particle-size distribution for } 42 \\
\text { lithologic samples from } 5 \text { wells. For area near Exeter. } \\
\text { Not on topographic base. }\end{array}$ \\
\hline & 1953 & GB 6 & $1: 122,000$ & $\begin{array}{l}\text { Records of wells and test borings show principal aquifer. } \\
\text { Lithologic logs for } 4 \text { wells. Not on topographic base. }\end{array}$ \\
\hline & 1960 & HB 3 & $1: 148,000$ & Lithologic log for 1 well. \\
\hline & 1961 & GB 11 & $1: 61,400$ & $\begin{array}{l}\text { Shows thickness of stratified-drift deposits in ranges of } \\
0-50,50-100 \text {, and } \geq 100 \mathrm{ft} \text {. Not on topographic base. }\end{array}$ \\
\hline & 1963 & GB 13 & $1: 24,000$ & $\begin{array}{l}\text { Well records show water-bearing material. Lithologic } \\
\text { logs for } 17 \text { wells. }\end{array}$ \\
\hline & 1966 & HB 6 & $1: 24,000$ & $\begin{array}{l}\text { Records of wells and test borings show water-bearing } \\
\text { materials for } 13 \text { wells. For South Branch Pawtuxet } \\
\text { Basin. }\end{array}$ \\
\hline & 1976 & WISR 2 & $1: 12,000$ & $\begin{array}{l}\text { Records of wells and test holes show water-bearing } \\
\text { materials for } 12 \text { wells. Lithologic logs for } 5 \text { wells. For } \\
\text { Chipuxet Basin. }\end{array}$ \\
\hline & 1984 & WRIR 83-4231 & various & Generalized geologic sections. For Chipuxet Basin. \\
\hline & 1985 & WRIR 84-4254 & various & Generalized geologic sections. For Chipuxet Basin. \\
\hline \multirow[t]{3}{*}{ Altitude of bedrock surface .......... } & 1948 & SC 2 & $1: 53,400$ & $\begin{array}{l}\text { Well records give approximate land-surface altitude and } \\
\text { depth to bedrock for } 4 \text { wells. Generalized geologic } \\
\text { sections show approximate altitude of bedrock. For } \\
\text { area near Exeter. Not on topographic base. }\end{array}$ \\
\hline & 1953 & GB 6 & $1: 122,000$ & $\begin{array}{l}\text { Records of wells and test borings give land-surface } \\
\text { altitude and depth to bedrock. Not on topographic } \\
\text { base. }\end{array}$ \\
\hline & 1959 & GWM 2 & $1: 24,000$ & $\begin{array}{l}\text { Approximate bedrock contours in stratified drift, } 50 \mathrm{ft} \\
\text { interval. Altitude of bedrock surface shown at well } \\
\text { locations. Bedrock outcrops in stratified drift shown. }\end{array}$ \\
\hline
\end{tabular}


Table 33. Geologic and hydrologic information for the Slocum Quadrangle--Continued

\begin{tabular}{|c|c|c|c|c|}
\hline Information & Date & Publication & Scale & Remarks \\
\hline \multirow[t]{4}{*}{ 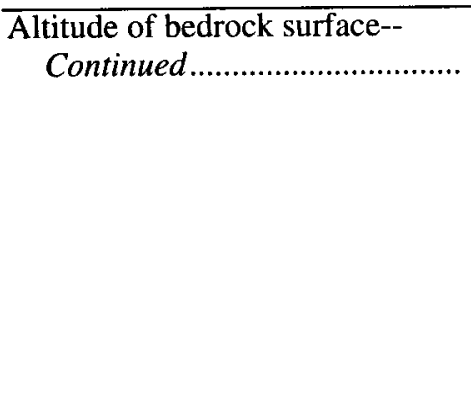 } & 1963 & GB 13 & $1: 24,000$ & $\begin{array}{l}\text { From seismic data and well records. For Upper } \\
\text { Pawcatuck Basin. }\end{array}$ \\
\hline & 1966 & HB 6 & $1: 24,000$ & $\begin{array}{l}\text { Records of wells and test borings give land-surface } \\
\text { altitude and depth to bedrock. For several wells. For } \\
\text { South Branch Pawtuxet Basin. }\end{array}$ \\
\hline & 1976 & WISR 2 & $1: 12,000$ & $\begin{array}{l}\text { Records of wells and test holes give land-surface altitude } \\
\text { and depth to bedrock. For } 1 \text { well. For Chipuxet Basin. }\end{array}$ \\
\hline & 1985 & WRIR 84-4254 & $1: 24,000$ & $\begin{array}{l}\text { Bedrock contours, } 25 \text { and } 50 \mathrm{ft} \text { intervals. For Chipuxet } \\
\text { Basin. }\end{array}$ \\
\hline \multirow[t]{6}{*}{ 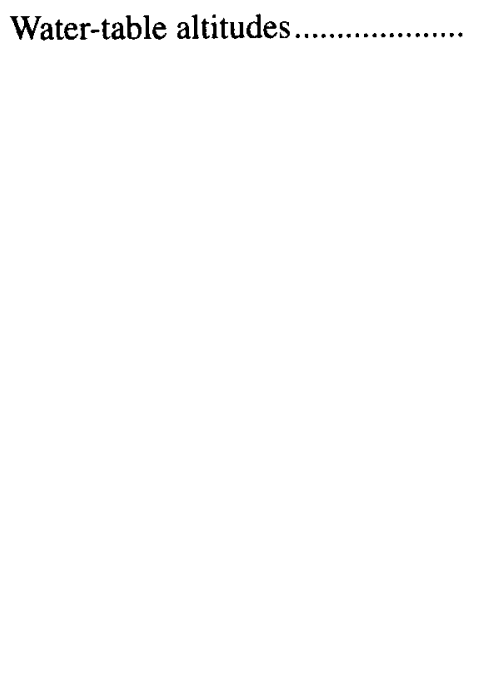 } & 1948 & $\mathrm{SC} 2$ & $1: 53,400$ & $\begin{array}{l}\text { Well records give approximate land-surface altitude and } \\
\text { depth to water for } 15 \text { wells. For area near Excter. Not } \\
\text { on topographic base. }\end{array}$ \\
\hline & 1953 & GB 6 & $1: 122,000$ & $\begin{array}{l}\text { Well records give land-surface altitude and depth to } \\
\text { water. Not on topographic base. }\end{array}$ \\
\hline & 1959 & GWM 2 & $1: 24,000$ & $\begin{array}{l}\text { Water-table altitudes shown at well locations. Data on } \\
\text { wells collected chiefly in } 1954 .\end{array}$ \\
\hline & 1963 & GB 13 & $1: 24,000$ & $\begin{array}{l}\text { Well records give land-surface altitude and depth to } \\
\text { water. Table of extreme values for some wells. For } \\
\text { Upper Pawcatuck Basin. }\end{array}$ \\
\hline & 1966 & HB 6 & $1: 24,000$ & $\begin{array}{l}\text { Well records give land-surface altitude and depth to } \\
\text { water. For several wells. For South Branch Pawtuxet } \\
\text { Basin. }\end{array}$ \\
\hline & 1976 & WISR 2 & $1: 12,000$ & $\begin{array}{l}\text { Descriptions of wells and test holes give land-surface } \\
\text { altitude and depth to water. For } 13 \text { wells. For Chipuxet } \\
\text { Basin. }\end{array}$ \\
\hline \multirow[t]{6}{*}{ Water-table contours.......................... } & 1959 & GWM 2 & $1: 24,000$ & $\begin{array}{l}\text { Approximate water-table contours in stratified drift and } \\
\text { mixed deposits, } 20 \mathrm{ft} \text { interval. Data on wells collected } \\
\text { chiefly in } 1954 \text {. }\end{array}$ \\
\hline & 1966 & WSP 1821 & $1: 24,000$ & $\begin{array}{l}\text { Water-table contours, } 5 \mathrm{ft} \text { interval. Based on } \\
\text { measurements made August 23, 1959. Water-table } \\
\text { altitudes shown at well locations. For Upper } \\
\text { Pawcatuck Basin. }\end{array}$ \\
\hline & 1968 & WSP 1775 & $1: 24,000$ & $\begin{array}{l}\text { Approximate contours, } 20 \mathrm{ft} \text { interval. For Hunt and } \\
\text { Annaquatucket Basins. }\end{array}$ \\
\hline & 1985 & WRIR 84-4254 & $1: 24,000$ & $\begin{array}{l}\text { Water-table contours, } 1,2 \text {, and } 5 \mathrm{ft} \text { intervals. For } \\
\text { Chipuxet Basin. }\end{array}$ \\
\hline & $\mathrm{U}$ & RAR 2 & $1: 24,000$ & $\begin{array}{l}\text { Water-table contours, } 20 \mathrm{ft} \text { interval. For Hunt, } \\
\text { Annaquatucket, and Queen Basins. Unpublished } \\
\text { report, available at Rhode Island Subdistrict Office, } \\
\text { U.S. Geological Survey. }\end{array}$ \\
\hline & $\mathrm{U}$ & RAR 3 & $1: 24,000$ & $\begin{array}{l}\text { Water-table contours, } 2 \text { and } 5 \mathrm{ft} \text { intervals. For Chipuxet } \\
\text { Basin. Unpublished report, available at Rhode Island } \\
\text { Subdistrict Office, U.S. Geological Survey. }\end{array}$ \\
\hline \multirow[t]{3}{*}{ 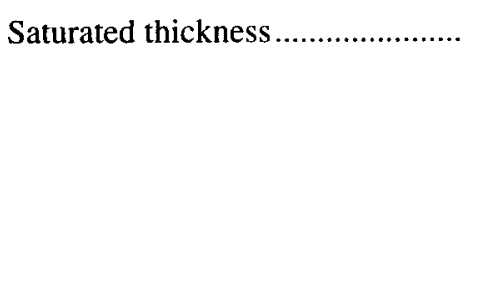 } & 1966 & WSP 1821 & $1: 24,000$ & $\begin{array}{l}\text { Lines of equal saturated thickness, } 25 \text { and } 50 \mathrm{ft} \text { intervals. } \\
\text { For Upper Pawcatuck Basin. }\end{array}$ \\
\hline & 1966 & HB 6 & $1: 24,000$ & $\begin{array}{l}\text { Can be estimated from water-table altitude and bedrock } \\
\text { altitude at well locations. For South Branch Pawtuxet } \\
\text { Basin. }\end{array}$ \\
\hline & 1968 & WSP 1775 & $1: 24,000$ & $\begin{array}{l}\text { Lines of equal saturated thickness, } 20 \mathrm{ft} \text { interval. For } \\
\text { Hunt and Annaquatucket Basins. }\end{array}$ \\
\hline
\end{tabular}


Table 33. Geologic and hydrologic information for the Slocum Quadrangle--Continued

\begin{tabular}{|c|c|c|c|c|}
\hline Information & Date & Publication & Scale & Remarks \\
\hline \multirow[t]{7}{*}{ Hydraulic conductivity ................ } & 1948 & SC 2 & NA & $\begin{array}{l}\text { Estimated from aquifer-test data for } 1 \text { site. Shown in } \\
\mathrm{gal} / \mathrm{d} / \mathrm{ft}^{2} \text {. For area near Exeter. }\end{array}$ \\
\hline & 1960 & HB 3 & $1: 148,000$ & $\begin{array}{l}\text { Computed from aquifer test on } 1 \text { well. Shown in } \\
\mathrm{gal} / \mathrm{d} / \mathrm{ft}^{2} \text {. }\end{array}$ \\
\hline & 1963 & GB 13 & $1: 24,000$ & $\begin{array}{l}\text { From laboratory analysis of sediment samples. Shown in } \\
\mathrm{gal} / \mathrm{d} / \mathrm{ft}^{2} \text {. For Upper Pawcatuck Basin. }\end{array}$ \\
\hline & 1966 & WSP 1821 & $1: 24,000$ & $\begin{array}{l}\text { Computed from aquifer tests, laboratory tests, and } \\
\text { specific capacity data. Shown in ranges of }<1-20 \text {, } \\
20-100,100-1,000, \text { and }>1,000 \mathrm{gal} / \mathrm{d} / \mathrm{ft}^{2} \text {. Well } \\
\text { locations shown. For Upper Pawcatuck Basin. }\end{array}$ \\
\hline & 1984 & WRIR 83-4231 & NA & $\begin{array}{l}\text { Estimated from lithologic logs and aquifer test data. } \\
\text { Shown in } \mathrm{ft} / \mathrm{d} \text {. For } 2 \text { sites. For Chipuxet Basin. }\end{array}$ \\
\hline & 1985 & WRIR 84-4254 & $1: 24,000$ & $\begin{array}{l}\text { Estimated from lithologic logs and aquifer-test data. } \\
\text { Shown in ranges of } 5-50,50-100, \text { and }>100 \mathrm{ft} / \mathrm{d} \text {. For } \\
\text { Chipuxet Basin. Maps in text show ranges for } 4 \text { layers } \\
\text { within aquifer. }\end{array}$ \\
\hline & 1992 & OFR $91-481$ & NA & Values for till in $\mathrm{cm} / \mathrm{s}$ for 1 site. \\
\hline \multirow[t]{6}{*}{ Transmissivity ............................... } & 1948 & $\mathrm{SC} 2$ & NA & $\begin{array}{l}\text { Estimated from aquifer-test data for } 1 \text { site. Shown in } \\
\mathrm{gal} / \mathrm{d} / \mathrm{ft} \text {. For area near Exeter. }\end{array}$ \\
\hline & 1960 & HB 3 & $1: 148,000$ & Computed from aquifer test on 1 well. Shown in $\mathrm{gal} / \mathrm{d} / \mathrm{ft}$. \\
\hline & 1966 & WSP 1821 & NA & $\begin{array}{l}\text { Estimated from aquifer tests and specific capacity data, } \\
\text { Shown in gal/d/ft. For Upper Pawcatuck Basin. }\end{array}$ \\
\hline & 1968 & WSP 1775 & $1: 24,000$ & $\begin{array}{l}\text { Lines of equal transmissivity, interval of } 20,000 \mathrm{gal} / \mathrm{d} / \mathrm{ft} \text {. } \\
\text { For Hunt and Annaquatucket Basins. }\end{array}$ \\
\hline & 1984 & WRIR 83-4231 & NA & $\begin{array}{l}\text { Estimated from lithologic logs, specific capacity data, } \\
\text { and aquifer-test data. Shown in } \mathrm{ft}^{2} / \mathrm{d} \text {. For } 2 \text { sites. } \\
\text { For Chipuxet Basin. }\end{array}$ \\
\hline & 1985 & WRIR 84-4254 & NA & $\begin{array}{l}\text { Estimated from lithologic logs, specific capacity data, } \\
\text { and aquifer-test data. For } 2 \text { sites. For Chipuxet Basin. }\end{array}$ \\
\hline \multirow[t]{9}{*}{ Drainage divides........................... } & 1963 & GB 13 & $1: 24,000$ & $\begin{array}{l}\text { Ground-water and surface-water divides. For Upper } \\
\text { Pawcatuck Basin. }\end{array}$ \\
\hline & 1966 & WSP 1821 & $1: 24,000$ & $\begin{array}{l}\text { Ground-water and surface-water divides. For Upper } \\
\text { Pawcatuck Basin. }\end{array}$ \\
\hline & 1966 & HB 6 & $1: 24,000$ & For South Branch Pawtuxet Basin. \\
\hline & 1968 & WSP 1775 & $1: 24,000$ & For Hunt and Annaquatucket Basins. \\
\hline & 1974 & WSP 2033 & $1: 48,000$ & For small area of Lower Pawcatuck Basin. \\
\hline & 1977 & WISR 3 & $1: 12,000$ & For Beaver Basin. \\
\hline & 1990 & WRIR 89-4164 & $1: 125,000$ & $\begin{array}{l}\text { For South Branch Pawtuxet, Hunt, and Annaquatucket } \\
\text { Basins. Not on topographic base. }\end{array}$ \\
\hline & $\mathrm{U}$ & RAR 2 & $1: 24,000$ & $\begin{array}{l}\text { For Hunt and Annaquatucket Basins. Unpublished } \\
\text { report, available at Rhode Island Subdistrict Office, } \\
\text { U.S. Geological Survey. }\end{array}$ \\
\hline & $\mathrm{U}$ & RAR 3 & $1: 24,000$ & $\begin{array}{l}\text { For Chipuxet Basin. Unpublished report, available at } \\
\text { Rhode Island Subdistrict Office, U.S. Geological } \\
\text { Survey. }\end{array}$ \\
\hline \multirow[t]{2}{*}{ Recharge areas............................. } & $\mathrm{U}$ & RAR 2 & $1: 24,000$ & $\begin{array}{l}\text { For Hunt ground-water reservoir. Unpublished report, } \\
\text { available at Rhode Island Subdistrict Office, U.S. } \\
\text { Geological Survey. }\end{array}$ \\
\hline & $\mathrm{U}$ & RAR 3 & $1: 24,000$ & $\begin{array}{l}\text { For Chipuxet ground-water reservoir. Unpublished } \\
\text { report, available at Rhode Island Subdistrict Office, } \\
\text { U.S. Geological Survey. }\end{array}$ \\
\hline
\end{tabular}


Table 33. Geologic and hydrologic information for the Slocum Quadrangle--Continued

\begin{tabular}{|c|c|c|c|c|}
\hline Information & Date & Publication & Scale & Remarks \\
\hline \multirow[t]{6}{*}{ Ground-water reservoirs................. } & 1948 & SC 2 & NA & $\begin{array}{l}\text { Aquifer-test data for } 1 \text { site near Exeter. For Usquepaug- } \\
\text { Queen ground-water reservoir. }\end{array}$ \\
\hline & 1966 & WSP 1821 & $1: 24,000$ & $\begin{array}{l}\text { Yields estimated for Usquepaug-Queen and Chipuxet } \\
\text { ground-water reservoirs. }\end{array}$ \\
\hline & 1976 & WISR 2 & $1: 12,000$ & $\begin{array}{l}\text { Aquifer test for } 1 \text { site. For Chipuxet ground-water } \\
\text { reservoir. }\end{array}$ \\
\hline & 1985 & WRIR 84-4254 & NA & $\begin{array}{l}\text { Estimated potential well yield for } 1 \text { site in Chipuxet } \\
\text { ground-water reservoir. }\end{array}$ \\
\hline & $\mathrm{U}$ & RAR 2 & $1: 24,000$ & $\begin{array}{l}\text { Shows Hunt ground-water reservoir. Unpublished report, } \\
\text { available at Rhode Island Subdistrict Office, U.S. } \\
\text { Geological Survey. }\end{array}$ \\
\hline & $\mathrm{U}$ & RAR 3 & $1: 24,000$ & $\begin{array}{l}\text { Shows Chipuxet ground-water reservoir. Unpublished } \\
\text { report, available at Rhode Island Subdistrict Office, } \\
\text { U.S. Geological Survey. }\end{array}$ \\
\hline \multirow[t]{7}{*}{ 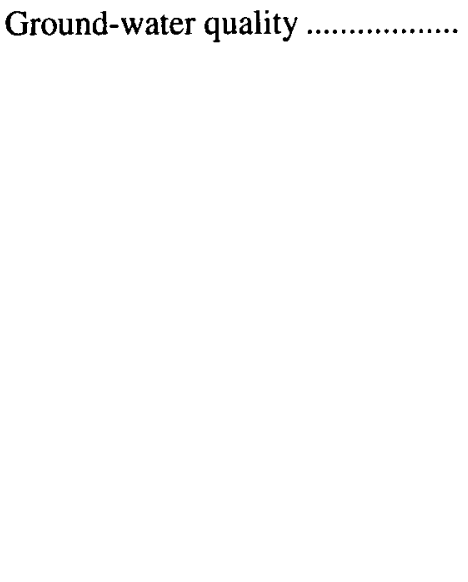 } & 1948 & SC 2 & $1: 53,400$ & $\begin{array}{l}\text { Major inorganic constituents for } 5 \text { wells. For area near } \\
\text { Exeter. Not on topographic base. }\end{array}$ \\
\hline & 1953 & GB 6 & $1: 122,000$ & $\begin{array}{l}\text { Major inorganic constituents, physical properties. For } 1 \\
\text { well. Not on topographic base. }\end{array}$ \\
\hline & 1963 & GB 13 & $1: 24,000$ & $\begin{array}{l}\text { Major inorganic constituents, physical properties. For } 16 \\
\text { wells. For Upper Pawcatuck Basin. }\end{array}$ \\
\hline & 1966 & WSP 1821 & $1: 24,000$ & $\begin{array}{l}\text { Dissolved solids, total hardness, iron, pH. For } 12 \text { wells. } \\
\text { For Upper Pawcatuck Basin. }\end{array}$ \\
\hline & 1966 & HB 6 & $1: 24,000$ & $\begin{array}{l}\text { Major inorganic constituents, physical properties. For } 1 \\
\text { well. For South Branch Pawtuxet Basin. }\end{array}$ \\
\hline & 1976 & WISR 2 & $1: 12,000$ & $\begin{array}{l}\text { Major inorganic constituents, physical properties. For } 2 \\
\text { wells. For Chipuxet Basin. }\end{array}$ \\
\hline & 1985 & WRIR 84-4254 & NA & $\begin{array}{l}\text { Summary of major inorganic constituents, detergents, } \\
\text { and physical properties. For Chipuxet Basin. }\end{array}$ \\
\hline
\end{tabular}


Table 34. Geologic and hydrologic information for the Thompson Quadrangle

\begin{tabular}{|c|c|c|c|c|}
\hline Information & Date & Publication & Scale & Remarks \\
\hline \multirow[t]{2}{*}{ Surficial geology ............................ } & 1961 & GB 12 & $1: 24,800$ & $\begin{array}{l}\text { Till and stratified-drift deposits. For Wallum Lake study } \\
\text { area. Not on topographic base. }\end{array}$ \\
\hline & 1962 & GWM 18 & $1: 24,000$ & $\begin{array}{l}\text { Till and stratified-drift deposits. For Rhode Island part of } \\
\text { quadrangle. }\end{array}$ \\
\hline \multirow[t]{2}{*}{ Bedrock geology ............................. } & 1971 & B 1295 & $1: 125,000$ & Bedrock geologic map of Rhode Island. \\
\hline & 1974 & GQ 1165 & $1: 24,000$ & $\begin{array}{l}\text { Detailed bedrock map. Geology mapped in } 1960,1962 \text {, } \\
\text { and } 1968 .\end{array}$ \\
\hline \multirow[t]{3}{*}{ Subsurface materials ..................... } & 1953 & GB 6 & $1: 122,000$ & $\begin{array}{l}\text { Well records show principal aquifer for } 1 \text { well. Not on } \\
\text { topographic base. }\end{array}$ \\
\hline & 1961 & GB 12 & $1: 24,800$ & $\begin{array}{l}\text { Well records give water-bearing materials for } \\
\text { approximately } 15 \text { wells. For Wallum Lake study area. } \\
\text { Not on topographic base. Generalized geologic } \\
\text { section. }\end{array}$ \\
\hline & 1974 & WRIR 18-74 & $1: 24,000$ & Shows areas of till $\geq 40 \mathrm{ft}$ thick. \\
\hline \multirow[t]{3}{*}{ Altitude of bedrock surface .......... } & 1953 & GB 6 & $1: 122,000$ & $\begin{array}{l}\text { Record for } 1 \text { well gives land-surface altitude and depth } \\
\text { to bedrock. Not on topographic base. }\end{array}$ \\
\hline & 1961 & GB 12 & $1: 24,800$ & $\begin{array}{l}\text { Altitude of bedrock surface given at well locations. } \\
\text { Wallum Lake study area. Not on topographic base. }\end{array}$ \\
\hline & 1962 & GWM 18 & $1: 24,000$ & $\begin{array}{l}\text { Approximate contours in stratified drift, } 100 \mathrm{ft} \text { interval. } \\
\text { Altitude of bedrock surface shown at well locations. }\end{array}$ \\
\hline \multirow[t]{2}{*}{ Water-table altitudes..................... } & 1953 & GB 6 & $1: 122,000$ & $\begin{array}{l}\text { Record for } 1 \text { well gives land-surface altitude and depth } \\
\text { to water. Not on topographic base. }\end{array}$ \\
\hline & 1962 & GWM 18 & $1: 24,000$ & $\begin{array}{l}\text { Water-table altitudes shown at well locations. Data on } \\
\text { wells collected chiefly in } 1961 .\end{array}$ \\
\hline \multirow[t]{2}{*}{ Water-table contours...................... } & 1961 & GB 12 & $1: 24,800$ & $\begin{array}{l}\text { Approximate water-table contours, } 40 \mathrm{ft} \text { interval. For } \\
\text { Wallum Lake study area. Not on topographic base. }\end{array}$ \\
\hline & 1962 & GWM 18 & $1: 24,000$ & $\begin{array}{l}\text { Approximate water-table contours in stratified drift, } 40 \mathrm{ft} \\
\text { interval. Data on wells collected chiefly in } 1961 \text {. }\end{array}$ \\
\hline Transmissivity ................................ & 1974 & WRIR 18-74 & $1: 24,000$ & $\begin{array}{l}\text { Estimated from lithologic logs. Shown in intervals of } \\
2,500 \mathrm{ft}^{2} / \mathrm{d} \text {. For Branch Basin. }\end{array}$ \\
\hline \multirow[t]{3}{*}{ Drainage divides........................... } & 1961 & GB 12 & $1: 24,800$ & $\begin{array}{l}\text { For subbasins of Quinebaug Basin. Not on topographic } \\
\text { base. }\end{array}$ \\
\hline & 1974 & WRIR 18-74 & $1: 24,000$ & For Branch Basin. \\
\hline & 1990 & WRIR 89-4164 & $1: 125,000$ & $\begin{array}{l}\text { For Blackstone, Branch, and North Branch Pawtuxet } \\
\text { Basins. Not on topographic base. }\end{array}$ \\
\hline
\end{tabular}


Table 35. Geologic and hydrologic information for the Tiverton Quadrangle

\begin{tabular}{|c|c|c|c|c|}
\hline Information & Date & Publication & Scale & Remarks \\
\hline Surficial geology ................................. & 1964 & GWM 21 & $1: 24,000$ & $\begin{array}{l}\text { Till, stratified drift, and mixed deposits. Not on } \\
\text { topographic base. }\end{array}$ \\
\hline \multirow[t]{3}{*}{ 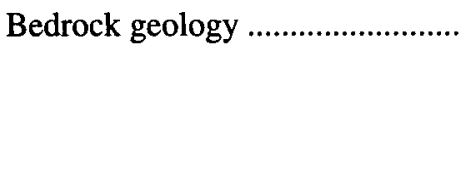 } & 1964 & B 1158-D & $1: 24,000$ & Detailed bedrock map. Geology mapped in 1955. \\
\hline & 1964 & GWM 21 & $1: 24,000$ & $\begin{array}{l}\text { Approximate contact between Pennsylvanian and pre- } \\
\text { Pennsylvanian bedrock. Not on topographic base. }\end{array}$ \\
\hline & 1971 & B 1295 & $1: 125,000$ & Bedrock geologic map of Rhode Island. \\
\hline \multirow[t]{2}{*}{ 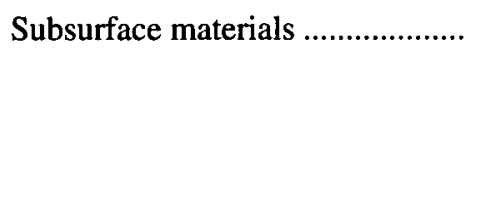 } & 1953 & GB 6 & $1: 122,000$ & $\begin{array}{l}\text { Records of wells and test borings show principal aquifer. } \\
\text { Lithologic logs for } 2 \text { wells. Not on topographic base. }\end{array}$ \\
\hline & 1964 & GWM 21 & $1: 24,000$ & $\begin{array}{l}\text { Shows areas of till greater than } 50 \mathrm{ft} \text { thick. Generalized } \\
\text { geologic section for small area. Not on topographic } \\
\text { base. }\end{array}$ \\
\hline \multirow[t]{2}{*}{ Altitude of bedrock surface .......... } & 1953 & GB 6 & $1: 122,000$ & $\begin{array}{l}\text { Records of wells and test borings give land-surface } \\
\text { altitude and depth to bedrock. Not on topographic } \\
\text { base. }\end{array}$ \\
\hline & 1964 & GWM 21 & $1: 24,000$ & $\begin{array}{l}\text { Depth to bedrock shown at well locations. Bedrock } \\
\text { outcrops shown. Not on topographic base. }\end{array}$ \\
\hline \multirow[t]{2}{*}{ Water-table altitudes ........................ } & 1953 & GB 6 & $1: 122,000$ & $\begin{array}{l}\text { Well records give land-surface altitude and depth to } \\
\text { water. Not on topographic base. }\end{array}$ \\
\hline & 1964 & GWM 21 & $1: 24,000$ & $\begin{array}{l}\text { Depth to water shown at well locations. Not on } \\
\text { topographic base. Data on wells collected chiefly in } \\
1949 \text { and } 1963 \text {. }\end{array}$ \\
\hline 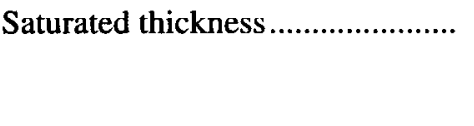 & 1964 & GWM 21 & $1: 24,000$ & $\begin{array}{l}\text { Can be estimated from depth to bedrock and depth to } \\
\text { water at some well locations. Not on topographic base. } \\
\text { Data on wells collected chiefly in } 1949 \text { and } 1963 \text {. }\end{array}$ \\
\hline 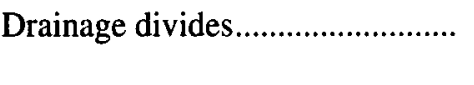 & 1990 & WRIR 89-4164 & $1: 125,000$ & $\begin{array}{l}\text { For Adamsville Basin and coastal areas. Not on } \\
\text { topographic base. }\end{array}$ \\
\hline Ground-water quality ......................... & 1964 & GWM 21 & $1: 24,000$ & $\begin{array}{l}\text { Shows wells that yield water with high iron content and } \\
\text { wells that yield salty water. }\end{array}$ \\
\hline
\end{tabular}


Table 36. Geologic and hydrologic information for the Uxbridge Quadrangle

\begin{tabular}{|c|c|c|c|c|}
\hline Information & Date & Publication & Scale & Remarks \\
\hline \multirow[t]{2}{*}{ Surficial geology ............................ } & 1961 & GB 12 & $1: 24,800$ & $\begin{array}{l}\text { Till and stratified-drift deposits. For Wallum Lake study } \\
\text { area. Not on topographic base. }\end{array}$ \\
\hline & 1962 & GWM 19 & $1: 24,000$ & $\begin{array}{l}\text { Till and stratified-drift deposits. For Rhode Island part of } \\
\text { quadrangle. }\end{array}$ \\
\hline Bedrock geology ............................... & 1971 & B 1295 & $1: 125,000$ & Bedrock geologic map of Rhode Island. \\
\hline Subsurface materials ....................... & 1961 & GB 12 & $1: 24,800$ & $\begin{array}{l}\text { Well records show water-bearing materials for a few } \\
\text { wells. For Wallum Lake study area. Not on } \\
\text { topegraphic base. }\end{array}$ \\
\hline \multirow[t]{2}{*}{ Altitude of bedrock surface .......... } & 1961 & GB 12 & $1: 24,800$ & $\begin{array}{l}\text { Approximate bedrock contours in stratified drift, } 50 \mathrm{ft} \\
\text { interval. For Wallum Lake study area. Not on } \\
\text { topographic base. }\end{array}$ \\
\hline & 1962 & GWM 19 & $1: 24,000$ & Altitude of bedrock surface shown at 3 wells. \\
\hline 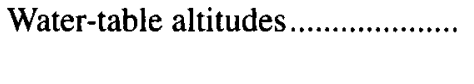 & 1962 & GWM 19 & $1: 24,000$ & $\begin{array}{l}\text { Water-table altitudes shown at well locations. Data on } \\
\text { wells collected chiefly in } 1961 \text {. }\end{array}$ \\
\hline \multirow[t]{2}{*}{ 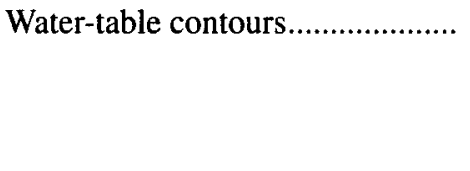 } & 1961 & GB 12 & $1: 24,800$ & $\begin{array}{l}\text { Approximate water-table contours, } 40 \mathrm{ft} \text { interval. For } \\
\text { Wallum Lake study area. Not on topographic base. }\end{array}$ \\
\hline & 1962 & GWM 19 & $1: 24,000$ & $\begin{array}{l}\text { Approximate contours in stratified drift, } 20 \mathrm{ft} \text { interval. } \\
\text { Data on wells collected chiefly in } 1961 .\end{array}$ \\
\hline Saturated thickness .......................... & 1974 & WRIR 18-74 & $1: 24,000$ & $\begin{array}{l}\text { Approximate lines of equal saturated thickness, } 20 \mathrm{ft} \\
\text { interval. For Branch Basin. }\end{array}$ \\
\hline 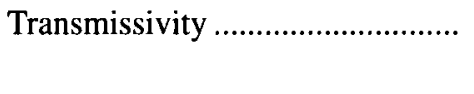 & 1974 & WRIR 18-74 & $1: 24,000$ & $\begin{array}{l}\text { Estimated from lithologic logs. Shown in intervals of } \\
2,500 \mathrm{ft}^{2} / \mathrm{d} \text {. For Branch Basin. }\end{array}$ \\
\hline \multirow[t]{2}{*}{ 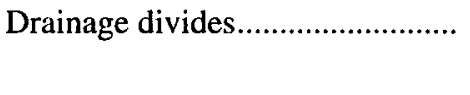 } & 1974 & WRIR 18-74 & $1: 24,000$ & For Branch Basin and subbasins. \\
\hline & 1990 & WRIR 89-4164 & $1: 125,000$ & For Branch Basin. Not on topographic base. \\
\hline 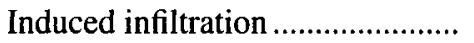 & 1974 & WRIR 18-74 & NA & Rates estimated for Branch Basin. \\
\hline
\end{tabular}


Table 37. Geologic and hydrologic information for the Voluntown Quadrangle

\begin{tabular}{|c|c|c|c|c|}
\hline Information & Date & Publication & Scale & Remarks \\
\hline \multirow[t]{4}{*}{ 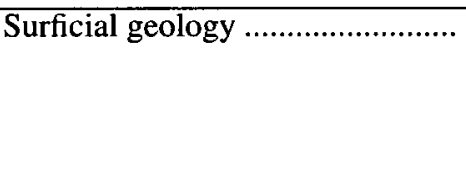 } & 1960 & GWM 13 & $1: 24,000$ & Till and stratified-drift deposits. \\
\hline & 1965 & GQ 469 & $1: 24,000$ & Detailed surficial map. Geology mapped 1962-64. \\
\hline & 1989 & WISR 5 & $1: 24,000$ & Till and stratified-drift deposits. For Upper Wood Basin. \\
\hline & 1993 & WRIR 92-4119 & $1: 68,700$ & Till and stratified-drift deposits. For Upper Wood Basin. \\
\hline \multirow[t]{2}{*}{ 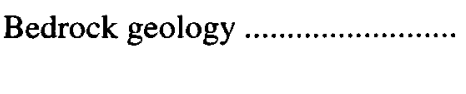 } & 1965 & GQ 436 & $1: 24,000$ & Detailed bedrock map. Geology mapped 1962-63. \\
\hline & 1971 & В 1295 & $1: 125,000$ & Bedrock geologic map of Rhode Island. \\
\hline \multirow[t]{3}{*}{ Subsurface materials ...................... } & 1953 & GB 6 & $1: 122,000$ & $\begin{array}{l}\text { Records of wells and test borings show principal aquifer. } \\
\text { Not on topographic base. }\end{array}$ \\
\hline & 1961 & GB 11 & $1: 61,400$ & $\begin{array}{l}\text { Shows stratified-drift deposits } 0-50 \mathrm{ft} \text { thick. For Rhode } \\
\text { Island part of quadrangle. Not on topographic base. }\end{array}$ \\
\hline & 1989 & WISR 5 & $1: 24,000$ & $\begin{array}{l}\text { Records of wells and test holes show principal water- } \\
\text { bearing material. For approximately } 50 \text { wells. For } \\
\text { Upper Wood Basin. }\end{array}$ \\
\hline \multirow[t]{5}{*}{ Altitude of bedrock surface ........... } & 1953 & GB 6 & $1: 122,000$ & $\begin{array}{l}\text { Records of wells and test borings give land-surface } \\
\text { altitude and depth to bedrock. Not on topographic } \\
\text { base. }\end{array}$ \\
\hline & 1960 & GWM 13 & $1: 24,000$ & Altitude of bedrock surface shown at well locations. \\
\hline & 1974 & WSP 2033 & $1: 48,000$ & $\begin{array}{l}\text { Approximate bedrock contours, } 50 \mathrm{ft} \text { interval. For Lower } \\
\text { Pawcatuck Basin. }\end{array}$ \\
\hline & 1989 & WISR 5 & $1: 24,000$ & $\begin{array}{l}\text { Records of wells and test holes give land-surface altitude } \\
\text { and depth to bedrock. For } 7 \text { wells. For Upper Wood } \\
\text { Basin. }\end{array}$ \\
\hline & 1993 & WRIR 92-4119 & $1: 54,100$ & $\begin{array}{l}\text { Bedrock contours, } 40 \text { and } 50 \mathrm{ft} \text { intervals. For Upper } \\
\text { Wood Basin. Not on topographic base. }\end{array}$ \\
\hline \multirow[t]{3}{*}{ 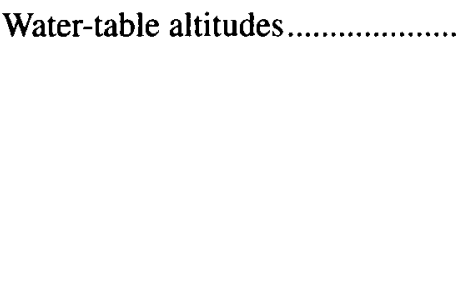 } & 1953 & GB 6 & $1: 122,000$ & $\begin{array}{l}\text { Well records give land-surface altitude and depth to } \\
\text { water. Not on topographic base. }\end{array}$ \\
\hline & 1960 & GWM 13 & $1: 24,000$ & $\begin{array}{l}\text { Water-table altitudes shown at well locations. Data on } \\
\text { wells collected in } 1953 \text { and } 1959 .\end{array}$ \\
\hline & 1989 & WISR 5 & $1: 24,000$ & $\begin{array}{l}\text { Records of wells and test holes give land-surface altitude } \\
\text { and depth to water. For approximately } 40 \text { wells. For } \\
\text { Upper Wood Basin. }\end{array}$ \\
\hline \multirow[t]{3}{*}{ 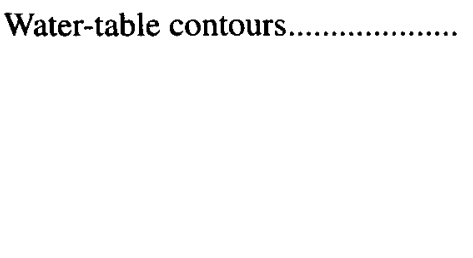 } & 1960 & GWM 13 & $1: 24,000$ & $\begin{array}{l}\text { Approximate contour in area near Beach Pond. Data on } \\
\text { wells collected in } 1953 \text { and } 1959 .\end{array}$ \\
\hline & 1974 & WSP 2033 & $1: 48,000$ & $\begin{array}{l}\text { Water-table contours in stratified drift, } 10 \mathrm{ft} \text { interval. For } \\
\text { Lower Pawcatuck Basin. }\end{array}$ \\
\hline & 1993 & WRIR 92-4119 & $1: 54,100$ & $\begin{array}{l}\text { Water-table contours in stratified drift, } 10 \mathrm{ft} \text { interval. For } \\
\text { Upper Wood Basin. Not on topographic base. }\end{array}$ \\
\hline 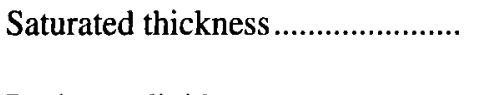 & 1974 & WSP 2033 & $1: 48,000$ & $\begin{array}{l}\text { Lines of equal saturated thickness, } 20 \mathrm{ft} \text { interval. For } \\
\text { Lower Pawcatuck Basin. }\end{array}$ \\
\hline \multirow[t]{3}{*}{ 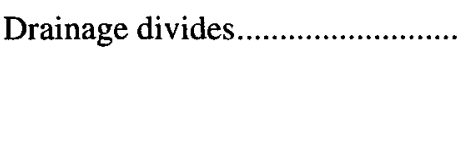 } & 1974 & WSP 2033 & $1: 48,000$ & For Lower Pawcatuck Basin. \\
\hline & 1989 & WISR 5 & $1: 24,000$ & For Upper Wood Basin. \\
\hline & 1993 & WRIR $92-4119$ & $1: 68,700$ & For Upper Wood Basin. \\
\hline 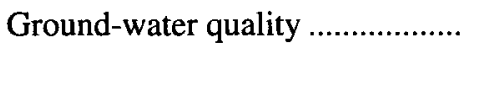 & 1989 & WISR 5 & $1: 24,000$ & $\begin{array}{l}\text { Major inorganic constituents, physical properties, } \\
\text { nutrients. For } 2 \text { wells. For Upper Wood Basin. }\end{array}$ \\
\hline
\end{tabular}


Table 38. Geologic and hydrologic information for the Watch Hill Quadrangle

\begin{tabular}{|c|c|c|c|c|}
\hline Information & Date & Publication & Scale & Remarks \\
\hline \multirow[t]{2}{*}{ Surficial geology .................................. } & 1961 & GWM 14 & $1: 24,000$ & Shows till, stratified drift, and mixed deposits. \\
\hline & 1965 & GQ 410 & $1: 24,000$ & Detailed surficial map. Geology mapped $1956,1959-60$. \\
\hline \multirow[t]{2}{*}{ Bedrock geology ............................. } & 1967 & GQ 655 & $1: 24,000$ & Detailed bedrock map. Geology mapped 1958-59. \\
\hline & 1971 & B 1295 & $1: 125,000$ & Bedrock geologic map of Rhode Island. \\
\hline \multirow[t]{2}{*}{ Subsurface materials ....................... } & 1953 & GB 6 & $1: 122,000$ & $\begin{array}{l}\text { Records of wells and test borings show principal aquifer. } \\
\text { Lithologic logs for } 7 \text { wells. Not on topographic base. }\end{array}$ \\
\hline & 1961 & GB 11 & $1: 61,400$ & $\begin{array}{l}\text { Shows stratified-drift deposits } 0-50 \mathrm{ft} \text { thick. For Rhode } \\
\text { Island part of quadrangle. Not on topographic base. }\end{array}$ \\
\hline \multirow[t]{3}{*}{ Altitude of bedrock surface........... } & 1953 & GB 6 & $1: 122,000$ & $\begin{array}{l}\text { Records of wells and test borings give land-surface } \\
\text { altitude and depth to bedrock. Not on topographic } \\
\text { base. }\end{array}$ \\
\hline & 1961 & GWM 14 & $1: 24,000$ & $\begin{array}{l}\text { Approximate bedrock contours in stratified drift and } \\
\text { mixed deposits, } 50 \mathrm{ft} \text { interval. Altitude of bedrock } \\
\text { surface shown at well locations. Bedrock outcrops } \\
\text { shown. }\end{array}$ \\
\hline & 1974 & WSP 2033 & $1: 48,000$ & $\begin{array}{l}\text { Approximate bedrock contours, } 50 \mathrm{ft} \text { interval. For Lower } \\
\text { Pawcatuck Basin. }\end{array}$ \\
\hline \multirow[t]{2}{*}{ Water-table altitudes... } & 1953 & GB 6 & $1: 122,000$ & $\begin{array}{l}\text { Well records give land-surface altitude and depth to } \\
\text { water. Not on topographic base. }\end{array}$ \\
\hline & 1961 & GWM 14 & $1: 24,000$ & $\begin{array}{l}\text { Water-table altitudes shown at well locations. Data on } \\
\text { wells collected chiefly in } 1958 .\end{array}$ \\
\hline \multirow[t]{2}{*}{ Water-table contours...................... } & 1961 & GWM 14 & $1: 24,000$ & $\begin{array}{l}\text { Approximate water-table contours in stratified drift and } \\
\text { mixed deposits, } 10 \text { and } 20 \mathrm{ft} \text { intervals. Data on wells } \\
\text { collected chiefly in } 1958 .\end{array}$ \\
\hline & 1974 & WSP 2033 & $1: 48,000$ & $\begin{array}{l}\text { Water-table contours in stratified drift, } 10 \mathrm{ft} \text { interval. For } \\
\text { Lower Pawcatuck Basin. }\end{array}$ \\
\hline 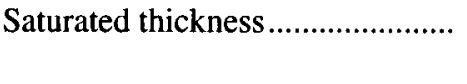 & 1974 & WSP 2033 & $1: 48,000$ & $\begin{array}{l}\text { Lines of equal saturated thickness, } 20 \mathrm{ft} \text { interval. For } \\
\text { Lower Pawcatuck Basin. }\end{array}$ \\
\hline Transmissivity ................................... & 1974 & WSP 2033 & $1: 48,000$ & $\begin{array}{l}\text { Lines of equal transmissivity, interval of } 2,500 \mathrm{ft}^{2} / \mathrm{d} \text {. For } \\
\text { Lower Pawcatuck Basin. }\end{array}$ \\
\hline Drainage divides................................ & 1974 & WSP 2033 & $1: 48,000$ & For Lower Pawcatuck Basin. \\
\hline
\end{tabular}

Table 39. Geologic and hydrologic information for the Westport Quadrangle

\begin{tabular}{ccccc}
\hline Information & Date & Publication & Scale & Remarks \\
\hline Surficial geology .......................... & 1964 & GWM 21 & $1: 24,000$ & $\begin{array}{c}\text { Till and stratified-drift deposits for Rhode Island part of } \\
\text { quadrangle. Not on topographic base. }\end{array}$ \\
Bedrock geology ........................ & 1971 & B 1295 & $1: 125,000$ & Bedrock geologic map of Rhode Island. \\
\hline
\end{tabular}


Table 40. Geologic and hydrologic information for the Wickford Quadrangle

\begin{tabular}{|c|c|c|c|c|}
\hline Information & Date & Publication & Scale & Remarks \\
\hline \multirow[t]{5}{*}{ Surficial geology ................................ } & 1959 & GWM 1 & $1: 24,000$ & Till, stratified drift, and mixed deposits. \\
\hline & 1961 & GQ 136 & $1: 24,000$ & Detailed surficial map. Geology mapped 1954-55. \\
\hline & 1966 & WSP 1821 & $1: 24,000$ & $\begin{array}{l}\text { Till and stratified-drift deposits. For small area of Upper } \\
\text { Pawcatuck Basin. }\end{array}$ \\
\hline & $\mathrm{U}$ & RAR 2 & $1: 24,000$ & $\begin{array}{l}\text { Till and stratified-drift deposits. For Hunt Basin. } \\
\text { Unpublished report, available at Rhode Island Subdis- } \\
\text { trict Office, U.S. Geological Survey. }\end{array}$ \\
\hline & $\mathrm{U}$ & RAR 3 & $1: 24,000$ & $\begin{array}{l}\text { Till and stratified-drift deposits. For Chipuxet Basin. } \\
\text { Unpublished report, available at Rhode Island } \\
\text { Subdistrict Office, U.S. Geological Survey. }\end{array}$ \\
\hline \multirow[t]{2}{*}{ 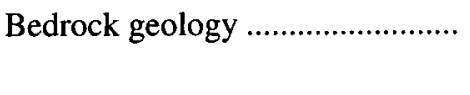 } & 1964 & B $1158-C$ & $1: 24,000$ & Detailed bedrock map. Geology mapped in 1956. \\
\hline & 1971 & В 1295 & $1: 125,000$ & Bedrock geologic map of Rhode Island. \\
\hline \multirow[t]{4}{*}{ Subsurface materials ...................... } & 1953 & GB 6 & $1: 122,000$ & $\begin{array}{l}\text { Records of wells and test borings show principal aquifer. } \\
\text { Lithologic logs for } 15 \text { wells. Not on topographic base. }\end{array}$ \\
\hline & 1960 & HB 3 & $1: 148,000$ & Lithologic $\log$ for 1 well. \\
\hline & 1961 & GB 11 & $1: 55,500$ & $\begin{array}{l}\text { Shows thickness of stratified-drift deposits in ranges of } \\
0-50,50-100 \text {, and }>100 \mathrm{ft} \text {. Not on topographic base. }\end{array}$ \\
\hline & 1963 & GB 13 & $1: 24,000$ & $\begin{array}{l}\text { Records of wells show water-bearing material. For } 4 \\
\text { wells. }\end{array}$ \\
\hline \multirow[t]{3}{*}{ Altitude of bedrock surface .......... } & 1953 & GB 6 & $1: 122,000$ & $\begin{array}{l}\text { Records of wells and test borings give land-surface } \\
\text { altitude and depth to bedrock. Not on topographic } \\
\text { base. }\end{array}$ \\
\hline & 1959 & GWM 1 & $1: 24,000$ & $\begin{array}{l}\text { Approximate bedrock contours in stratified drift, } 50 \mathrm{ft} \\
\text { interval. Altitude of bedrock surface shown at well } \\
\text { locations. Bedrock outcrops in stratified drift and } \\
\text { mixed deposits shown. }\end{array}$ \\
\hline & 1963 & GB 13 & $1: 24,000$ & From seismic data and well records. For 2 locations. \\
\hline \multirow[t]{3}{*}{ 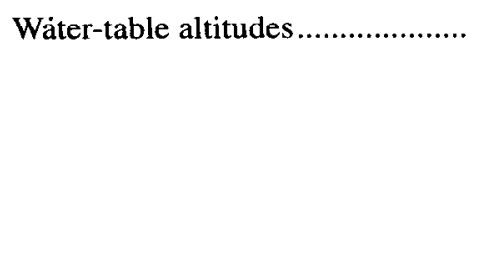 } & 1953 & GB 6 & $1: 122,000$ & $\begin{array}{l}\text { Well records give land-surface altitude and depth to } \\
\text { water. Not on topographic base. }\end{array}$ \\
\hline & 1959 & GWM 1 & $1: 24,000$ & $\begin{array}{l}\text { Water-table altitudes shown at well locations. Data on } \\
\text { wells collected chiefly in } 1954 .\end{array}$ \\
\hline & 1963 & GB 13 & $1: 24,000$ & $\begin{array}{l}\text { Well records give land-surface altitude and depth to } \\
\text { water. For } 2 \text { wells. }\end{array}$ \\
\hline \multirow[t]{5}{*}{ 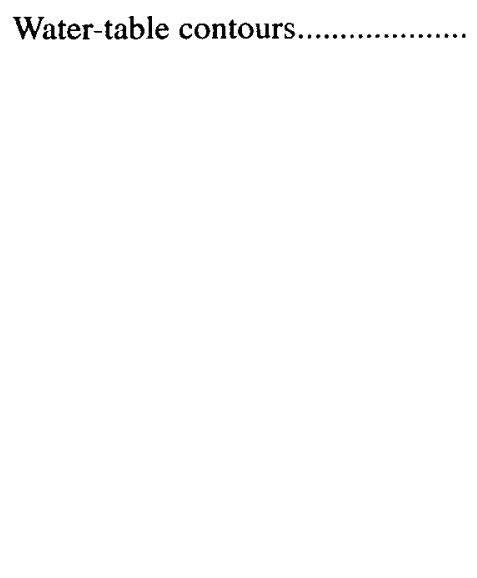 } & 1959 & GWM 1 & $1: 24,000$ & $\begin{array}{l}\text { Approximate contours in stratified drift and mixed } \\
\text { deposits, } 10 \text { and } 20 \mathrm{ft} \text { intervals. Data on wells } \\
\text { collected chiefly in } 1954 .\end{array}$ \\
\hline & 1966 & WSP 1821 & $1: 24,000$ & $\begin{array}{l}\text { Water-table contours, } 5 \mathrm{ft} \text { interval. Based on } \\
\text { measurements made August 23, 1959. For small area } \\
\text { of Upper Pawcatuck Basin. }\end{array}$ \\
\hline & 1968 & WSP 1775 & $1: 24,000$ & $\begin{array}{l}10 \text { and } 20 \mathrm{ft} \text { intervals. For Hunt, Annaquatucket, and } \\
\text { Pettaquamscutt Basins and coastal areas. }\end{array}$ \\
\hline & $\mathrm{U}$ & RAR 2 & $1: 24,000$ & $\begin{array}{l}\text { Water-table contours, } 10 \text { and } 20 \mathrm{ft} \text { intervals. For Hunt } \\
\text { Basin. Unpublished report, available at Rhode Island } \\
\text { Subdistrict Office, U.S. Geological Survey. }\end{array}$ \\
\hline & $\mathrm{U}$ & RAR 3 & $1: 24,000$ & $\begin{array}{l}\text { Water-table contours, } 5 \mathrm{ft} \text { interval. For Chipuxet Basin. } \\
\text { Unpublished report, available at Rhode Island } \\
\text { Subdistrict Office, U.S. Geological Survey. }\end{array}$ \\
\hline 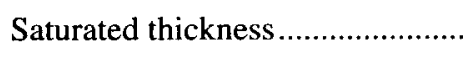 & 1966 & WSP 1821 & $1: 24,000$ & $\begin{array}{l}\text { Lines of equal saturated thickness, } 25 \text { and } 50 \mathrm{ft} \text { intervals. } \\
\text { For small area of Upper Pawcatuck Basin. }\end{array}$ \\
\hline
\end{tabular}


Table 40. Geologic and hydrologic information for the Wickford Quadrangle--Continued

\begin{tabular}{|c|c|c|c|c|}
\hline Information & Date & Publication & Scale & Remarks \\
\hline \multirow[t]{3}{*}{ Hydraulic conductivity ................. } & 1968 & WSP 1775 & $1: 24,000$ & $\begin{array}{l}\text { Lines of equal saturated thickness, } 20 \mathrm{ft} \text { interval. For } \\
\text { Hunt, Annaquatucket, and Pettaquamscutt Basins and } \\
\text { coastal areas. }\end{array}$ \\
\hline & 1960 & HB 3 & $1: 148,000$ & $\begin{array}{l}\text { Computed from aquifer test on } 1 \text { well. Shown in } \\
\mathrm{gal} / \mathrm{d} / \mathrm{ft}^{2} \text {. }\end{array}$ \\
\hline & 1966 & WSP 1821 & $1: 24,000$ & $\begin{array}{l}\text { Shows stratitied drift with average range of } \\
20-100 \mathrm{gal} / \mathrm{d} / \mathrm{ft}^{2} \text {. For small area of Upper Pawcatuck } \\
\text { Basin. }\end{array}$ \\
\hline \multirow{2}{*}{ 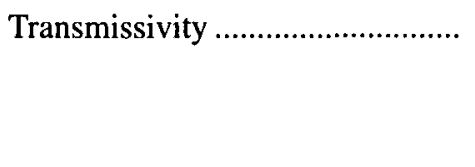 } & 1960 & HB 3 & $1: 148,000$ & Computed from aquifer test on 1 well. Shown in gal $/ \mathrm{d} / \mathrm{ft}$. \\
\hline & 1968 & WSP 1775 & $1: 24,000$ & $\begin{array}{l}\text { Lines of equal transmissivity, } 20,000 \text { and } \\
100,000 \mathrm{gal} / \mathrm{d} / \mathrm{ft} \text { intervals. For Hunt, Annaquatucket, } \\
\text { and Pettaquamscult Basins and coastal areas. }\end{array}$ \\
\hline \multirow[t]{6}{*}{ Drainage divides............................ } & 1963 & GB 13 & $1: 24,000$ & $\begin{array}{l}\text { Ground-water and surface-water divides. For small area } \\
\text { of Upper Pawcatuck Basin. }\end{array}$ \\
\hline & 1966 & WSP 1821 & $1: 24,000$ & $\begin{array}{l}\text { Ground-water and surface-water divides. For small area } \\
\text { of Upper Pawcatuck Basin. }\end{array}$ \\
\hline & 1968 & WSP 1775 & $1: 24,000$ & For Annaquatucket and Pettaquamscutt Basins. \\
\hline & 1990 & WRIR 89-4164 & $1: 125,000$ & $\begin{array}{l}\text { For Hunt and Annaquatucket Basins and small coastal } \\
\text { basins. Not on topographic base. }\end{array}$ \\
\hline & $\mathrm{U}$ & RAR 2 & $1: 24,000$ & $\begin{array}{l}\text { For Hunt Basin. Unpublished report, available at Rhode } \\
\text { Island Subdistrict Office, U.S. Geological Survey. }\end{array}$ \\
\hline & $\mathrm{U}$ & RAR 3 & $1: 24,000$ & $\begin{array}{l}\text { For small area of Chipuxet Basin. Unpublished report, } \\
\text { available at Rhode Island Subdistrict Office, U.S. } \\
\text { Geological Survey. }\end{array}$ \\
\hline \multirow[t]{2}{*}{ Recharge areas............................ } & $\mathrm{U}$ & RAR 2 & $1: 24,000$ & $\begin{array}{l}\text { For Hunt ground-water reservoir. Unpublished report, } \\
\text { available at Rhode Island Subdistrict Office, U.S. } \\
\text { Geological Survey. }\end{array}$ \\
\hline & $\mathrm{U}$ & RAR 3 & $1: 24,000$ & $\begin{array}{l}\text { For Chipuxet ground-water reservoir. Unpublished } \\
\text { report, available at Rhode Island Subdistrict Office, } \\
\text { U.S. Geological Survey. }\end{array}$ \\
\hline \multirow[t]{2}{*}{ Ground-water reservoirs................ } & 1968 & WSP 1775 & $1: 24,000$ & $\begin{array}{l}\text { Mathematical model used to evaluate yields for Hunt and } \\
\text { Annaquatucket ground-water reservoirs. Yield } \\
\text { estimated for Pettaquamscutt ground-water reservoir. }\end{array}$ \\
\hline & $\mathrm{U}$ & RAR 2 & $1: 24,000$ & $\begin{array}{l}\text { Shows Hunt ground-water reservoir. Unpublished report, } \\
\text { available at Rhode Island Subdistrict Office, U.S. } \\
\text { Geological Survey. }\end{array}$ \\
\hline Induced infiltration ....................... & 1968 & WSP 1775 & NA & $\begin{array}{l}\text { Potential streambed infiltration rates estimated for the } \\
\text { Hunt River. }\end{array}$ \\
\hline Ground-water quality ..................... & 1953 & GB 6 & $1: 122,000$ & $\begin{array}{l}\text { Major inorganic constituents, physical properties. For } 2 \\
\text { wells. Not on topographic base. }\end{array}$ \\
\hline
\end{tabular}


Table 41. List of publications pertaining to the geology and hydrology of Rhode Island

[Publications have been prepared and published by the U.S. Geological Survey, or prepared by the Survey and published in cooperation with State agencies. Many publications havc multiple maps or plates, which may be at different scales. Where a scale is shown in this table, it is the scale for the major map or plate in the report. Publications are listed numerically within each publication series, to facilitate reference from tables 4 through 40 . The abbreviation used for each publication series is shown in parentheses]

\section{BULLETINS (B)}

Published by the U.S. Geological Survey.

101 Insect fauna of the Rhode Island coal field, by S.H. Scudder, 1893, 27 p.

311 The green schists and associated granites and porphyries of Rhode Island, by B.K. Emerson and J.H. Perry, 1907, 74 p., 1 pl., scale 1:62,500.

354 The chief commercial granites of Massachusetts, New Hampshire, and Rhode Island, by T.N. Dale, 1908, $228 \mathrm{p}$.

597 Geology of Massachusetts and Rhode Island, by B.K. Emerson, 1917, 289 p., 10 pl., scale 1:250,000.

615 Rhode Island coal, by G.H. Ashley, 1915, 62 p., 1 pl., scale 1:312,500.

1071-I Surficial geology of the Kingston quadrangle, Rhode Island, by C.A. Kaye, 1960 (1961), p. 341-394, 3 pl., scale $1: 24,000$.

1158-A Bedrock geology of the Coventry Center quadrangle, Rhode Island, by G.E. Moore, Jr., 1963, p. A1-A24, 1 pl., scale $1: 24,000$.

1158-B Bedrock geology of the Crompton quadrangle, Rhode Island, by A.W. Quinn, 1963, p. B1-B17, 1 pl., scale $1: 24,000$.

1158-C Bedrock geology of the Wickford quadrangle, Rhode Island, by R.B. Williams, 1964, p. C1-C15, 1 pl., scale $1: 24,000$.

1158-D Bedrock geology of the Tiverton quadrangle, Rhode Island-Massachusetts, by S.J. Pollock, 1964, p. D1-D16, 1 pl., scale 1:24,000.

1158-E Bedrock geology of the Kingston quadrangle, Rhode Island, by G.E. Moore, Jr., 1964, p. E1-E21, 1 pl., scale 1:24,000.

1241-G Bedrock geology of the Chepachet quadrangle, Providence County, Rhode Island, by A.W. Quinn, 1967, p. G1-G26, 1 pl., scale 1:24,000.

1295 Bedrock geology of Rhode Island, by A.W. Quinn, 1971, 68 p., 1 pl., scale 1:125,000.

\section{GEOLOGIC QUADRANGLES (GQ)}

$1 \quad$ Bedrock geology of the Pawtucket quadrangle, Rhode Island-Massachusetts, by A.W. Quinn, R.G. Ray, and W.L. Seymour, 1949, scale 1:31,680.

2

Surficial geology of the Pawtucket quadrangle, Rhode Island-Massachusetts, by N.E. Chute, 1949, scale $1: 31,680$.

13

16

17

22

42

62

70

84

91

94

105

106

114

117
Bedrock geology of the North Scituate quadrangle, Rhode Island, by A.W. Quinn, 1951, scale 1:31,680.

Bedrock geology of the Georgiaville quadrangle, Rhode Island, by G.M. Richmond, 1952, scale 1:31,680.

Bedrock geology of the East Greenwich quadrangle, Rhode Island, by A.W. Quinn, 1952, scale 1:31,680.

Surficial geology of the Georgiaville quadrangle, Rhode Island, by G.M. Richmond, 1953, scale 1:31,680.

Bedrock geology of the Bristol quadrangle and vicinity, Rhode Island-Massachusetts, by A.W. Quinn and G.H. Springer, 1954, scale 1:31,680.

Surficial geology of the East Greenwich quadrangle, Rhode Island, by J.H. Smith, 1955, scale 1:31,680.

Surficial geology of the Bristol quadrangle and vicinity, Rhode Island-Massachusetts, by J.H. Smith, 1955, scale 1:31,680.

Surficial geology of the Providence quadrangle, Rhode Island, by J.H. Smith, 1956, scale 1:31,680.

Bedrock geology of the Narragansett Pier quadrangle, Rhode Island, by D.R. Nichols, 1956, scale 1:31,680.

Surficial geology of the Crompton quadrangle, Rhode Island, by J.H. Smith, 1956, scale 1:31,680.

Bedrock geology of the Hope Valley quadrangle, Rhode Island, by G.E. Moore, Jr., 1958, scale 1:31,680.

Surficial geology of the Slocum quadrangle, Rhode Island, by W.R. Power, Jr., 1957, scale 1:31,680.

Bedrock geology of the Slocum quadrangle, Rhode Island, by W.R. Power, Jr., 1959, scale 1:31,680.

Bedrock geology of the Carolina and Quonochontaug quadrangles, Rhode Island, by G.E. Moore, Jr., 1959, scale $1: 31,680$. 
Table 41. List of publications pertaining to the geology and hydrology of Rhode Island--Continued

\section{GEOLOGIC QUADRANGLES (GQ)--Continued}

\begin{tabular}{ll}
\hline Published by the U.S. Geological Survey. \\
118 & Bedrock geology of the Providence quadrangle, Rhode Island, by A.W. Quinn, 1959, scale 1:24,000. \\
136 & Surficial geology of the Wickford quadrangle, Rhode Island, by J.P. Schafer, 1961, scale 1:24,000. \\
140 & Surficial geology of the Narragansett Pier quadrangle, Rhode Island, by J.P. Schafer, 1961, scale $1: 24,000$. \\
143 & Surficial geology of the North Scituate quadrangle, Rhode Island, by C.S. Robinson, 1961, scale $1: 24,000$. \\
166 & Surficial geology of the Hope Valley quadrangle, Rhode Island, by T.G. Feininger, 1962, scale 1:24,000. \\
403 & Bedrock geologic map of the Ashaway quadrangle, Connecticut-Rhode Island, by T. Feininger, 1965, scale \\
& $1: 24,000$. \\
410 & Surficial geologic map of the Watch Hill quadrangle, Rhode Island-Connecticut, by J.P. Schafer, 1965, scale \\
& $1: 24,000$. \\
436 & Bedrock geologic map of the Voluntown quadrangle, New London County, Connecticut, and Kent and \\
& Washington Counties, Rhode Island, by T. Feininger, 1965, scale 1:24,000. \\
469 & Surficial geologic map of the Voluntown quadrangle, Connecticut-Rhode Island, by T. Feininger, 1965, scale \\
& $1: 24,000$. \\
655 & Bedrock geologic map of the Watch Hill quadrangle, Washington County, Rhode Island, and New London \\
& County, Connecticut, by G.E. Moore, Jr., 1967, scale 1:24,000. \\
712 & Surficial geologic map of the Ashaway quadrangle, Connecticut-Rhode Island, by J.P. Schafer, 1968, scale \\
& $1: 24,000$. \\
917 & Surficial geologic map of the Oneco quadrangle, Connecticut-Rhode Island, by D.S. Harwood and Richard \\
& Goldsmith, 1971, scale 1:24,000. \\
930 & Bedrock geologic map of the Oneco quadrangle, Connecticut-Rhode Island, by D.S. Harwood and Richard \\
Goldsmith, 1971, scale 1:24,000. \\
940 \\
Surficial geologic map of the Mystic quadrangle, Connecticut, New York, and Rhode Island, by J.E. Upson, \\
1971, scale 1:24,000. \\
Bedrock geologic map of the Thompson quadrangle, Windham County, Connecticut, and Providence County, \\
Rhode Island, by H.R. Dixon, 1974, scale 1:24,000. \\
Bedrock geologic map of the East Killingly quadrangle, Connecticut and Rhode Island, by G.E. Moore, Jr., \\
1983, scale 1:24,000.
\end{tabular}

MONOGRAPHS (M)

33 Geology of the Narragansett Basin, by N.S. Shaler, J.B. Woodworth, and A.F. Foerste, 1899, 402 p.

\section{OPEN-FILE REPORTS (OFR)}

75-562 Preliminary bedrock geologic maps of the Newport and Prudence Island quadrangles and part of the Sakonnet Point quadrangle, Rhode Island, by G.E. Moore, Jr., 1975, 12 p., 3 pl., scale 1:24,000.

75-602 Preliminary bedrock geologic map of the Mystic quadrangle, New London County, Conn.; Southold County, N.Y.; and Washington County, R.I., by Richard Goldsmith, 1975, 16 p., 1 pl., scale 1:24,000.

76-622 Preliminary bedrock geologic map of the Oxford quadrangle, Massachusetts, Connecticut, and Rhode Island, by P.J. Barosh, 1976, 5 p., 1 pl., scale 1:24,000.

77-131 Preliminary map showing bedrock geology superposed on an aeromagnetic base map of the Worcester region, Massachusetts, Connecticut, and Rhode Island, by P.J. Barosh, 1977, 46 p., 2 pl., scale 1:125,000.

77-561 Preliminary study of sources and processes of enrichment of manganese in water from University of Rhode Island supply wells, by W.D. Silvey and H.E. Johnston, 1977, 33 p.

77-816 Report on the bedrock geology of the Narragansett Basin, Massachusetts and Rhode Island, by P.C. Lyons, 1977 , scale $1: 31,250$.

84-725 Geohydrologic data for a low-level radioactive contamination site, Wood River Junction, Rhode Island, by

B.J. Ryan, R.M. DeSaulniers, D.A. Bristol, Jr., and P.M. Barlow, 1985, 296 p., 1 pl.

88-139 U.S. Geological Survey ground-water studies in Rhode Island, by H.E. Johnston, 1988, 1 sheet.

91-199 Ground-water resources of Rhode Island, by E.C.T. Trench, 1991, 169 p. 
Table 41. List of publications pertaining to the geology and hydrology of Rhode Island--Continued

\section{OPEN-FILE REPORTS--Continued}

Published by the U.S. Geological Survey.

91-481 The stratigraphy and hydraulic properties of tills in southern New England, by R.L. Melvin, Virginia de Lima, and B.D. Stone, 1992, 53 p.

92-49 Generalized water-table map of Block Island, Rhode Island, by H.E. Johnston and A.I. Veeger, 1994, 1 sheet, scale $1: 12,000$.

92-155 Hydrologic data for Block Island, Rhode Island, by Emily Burns, 1993, 141 p., 1 pl., scale 1:12,000.

\section{PROFESSIONAL PAPERS (PP)}

424-C A seismic record of Mesozoic rocks on Block Island, Rhode Island, by C.R. Tuttle, W.B. Allen, and G.W. Hahn, 1961, p. C254-C256.

813-T Summary appraisals of the Nation's ground-water resources--New England Region, by Allen Sinnott, 1982, p. T1-T23.

\section{WATER DATA REPORTS}

National ground-water records prior to water year 1975 were reported by geographic area in a 5-year Water-Supply Paper series. Data for Rhode Island are in Water-Supply Papers entitled "Ground-Water Levels in the United States, Northeastern States."

MA-RI-75-1 Water resources data for Massachusetts and Rhode Island, water year 1975, by U.S. Geological Survey, 1976, $321 \mathrm{p}$.

MA-RI-76-1 Water resources data for Massachusetts and Rhode Island, water year 1976, by U.S. Geological Survey, 1977, $300 \mathrm{p}$.

MA-RI-77-1 Water resources data for Massachusetts and Rhode Island, water year 1977, by U.S. Geological Survey, 1978, $304 \mathrm{p}$.

MA-RI-78-1 Water resources data for Massachusetts and Rhode Island, water year 1978, by U.S. Geological Survey, 1979, $310 \mathrm{p}$.

MA-RI-79-1 Water resources data for Massachusetts and Rhode Island, water year 1979, by U.S. Geological Survey, 1980, $349 \mathrm{p}$.

MA-RI-80-1 Water resources data for Massachusetts and Rhode Island, water year 1980, by U.S. Geological Survey, 1981, $348 \mathrm{p}$.

MA-RI-81-1 Water resources data for Massachusetts and Rhode Island, water year 1981, by U.S. Geological Survey, 1982, $292 \mathrm{p}$.

MA-RI-82-1 Water resources data for Massachusetts and Rhode Island, water year 1982, by R.A. Gadoury, G.G. Girouard, and D.F. Letty, 1983, 237 p.

MA-RI-83-1 Water resources data for Massachusetts and Rhode Island, water year 1983, by R.A. Gadoury, G.G. Girouard, and K.G. Ries, III, 1985, 237 p.

MA-RI-84-1 Water resources data for Massachusetts and Rhode Island, water year 1984, by R.A. Gadoury, G.G. Girouard, and K.G. Ries, III, and H.L. White, 1986, 212 p.

MA-RI-85-1 Water resources data for Massachusetts and Rhode Island, water year 1985, by R.A. Gadoury, D.J. Kent, K.G. Ries, III, and H.L. White, 1987, 235 p.

MA-RI-86-1 Water resources data for Massachusetts and Rhode Island, water year 1986, by R.A. Gadoury, D.J. Kent, K.G. Ries, III, and H.L. White, 1988, 251 p.

MA-RI-87-1 Water resources data for Massachusetts and Rhode Island, water year 1987, by R.A. Gadoury, R.S. Socolow, D.J. Kent, and J.P. Russell, 1989, 243 p.

MA-RI-88-1 Water resources data for Massachusetts and Rhode Island, water year 1988, by R.A. Gadoury, R.S. Socolow, R.W. Bell, and T.J. Calderini, 1990, 231 p.

MA-RI-89-1 Water resources data for Massachusetts and Rhode Island, water year 1989, by R.S. Socolow, R.A. Gadoury, L.R. Ramsbey, and R.W. Bell, 1991, 227 p.

MA-RI-90-1 Water resources data for Massachusetts and Rhode Island, water year 1990, by R.S. Socolow, R.A. Gadoury, L.R. Ramsbey, and R.W. Bell, 1991, 260 p.

MA-RI-91-1 Water resources data for Massachusetts and Rhode Island, water year 1991, by R.A. Gadoury, R.S. Socolow, and L.R. Ramsbey, 1992, 247 p. 
Table 41. List of publications pertaining to the geology and hydrology of Rhode Island--Continued

\section{WATER-RESOURCES INVESTIGATIONS REPORTS (WRIR)}

4-74 Availability of ground water in the Blackstone River area, Rhode Island and Massachusetts, by H.E. Johnston and D.C. Dickerman, 1974, 2 sheets, scale 1:24,000.

18-74 Availability of ground water in the Branch River Basin, Providence County, Rhode Island, by H.E. Johnston and D.C. Dickerman, 1974, 39 p., 1 pl., scale 1:24,000.

83-4231 Aquifer tests in the stratified drift, Chipuxet River Basin, Rhode Island, D.C. Dickerman, 1984,39 p.

83-4251 A modification of the finite-difference model for simulation of two-dimensional ground-water flow to include surface-ground water relationships, by M.M. Ozbilgin and D.C. Dickerman, 1984, 98 p.

84-4254 Hydrology, water quality, and ground-water-development alternatives in the Chipuxet ground-water reservoir, Rhode Island, by H.E. Johnston and D.C. Dickerman, 1985, 100 p., 1 pl., scale 1:24,000.

84-4367 Water quality of Rhode Island streams, by J.C. Briggs and J.S. Feiffer, 1986, 51 p.

85-4190 Hydrogeology, water quality, and ground-water-development alternatives in the Beaver-Pasquiset groundwater reservoir, Rhode Island, by D.C. Dickerman and M.M. Ozbilgin, 1985, 104 p.

89-4031 Hydrogeology, water quality, and ground-water-development alternatives in the lower Wood River groundwater reservoir, Rhode Island, by D.C. Dickerman, E.C.T. Trench, and J.P. Russell, 1990, 109 p.

89-4164 Estimating surface-water runoff to Narragansett Bay, Rhode Island and Massachusetts, by K.G. Ries, III, 1990, 44 p., scuale $1: 125,000$.

90-4082 Rhode Island streams-1978-88, an update on water-quality conditions, by J.C. Briggs, 1990, 39 p.

90-4207 Plan for developing a water-use data program in Rhode Island, by M.A. Horn and P.A. Craft, 1991,26 p.

92-4119 Hydrogeology, water quality, and ground-water-development alternatives in the Upper Wood River groundwater reservoir, Rhode Island, by D.C. Dickerman and R.W. Bell, 1993, 87 p.

\section{WATER-SUPPLY PAPERS (WSP)}

National ground-water records prior to water year 1975 were reported by geographic area in a 5-year Water-Supply Paper series. Data for Rhode Island are in Water-Supply Papers entitled "Ground-Water Levels in the United States, Northeastern States."

102 Notes on the wells, springs, and general water resources of certain eastern and central States--Rhode Island, by W.O. Crosby, 1904, in Contributions to the hydrology of eastern United States, 1903, p. 119-125.

114 Massachusetts and Rhode Island, by W.O. Crosby, 1905, in Underground waters of eastern United States, p. $68-75$.

1499-A Water resources of the Providence area, Rhode Island, by H.N. Halberg, C.E. Knox, and F.H. Pauszek, 1961, 50 p., 1 pl., scale 1:125,000.

1775 Hydrologic characteristics and sustained yield of principal ground-water units, Potowomut-Wickford area, Rhode Island, by J.S. Rosenshein, J.B. Gonthier, and W.B. Allen, 1968, 38 p., 5 pl., scale 1:24,000.

1800 The role of ground water in the national water situation, by C.L. McGuinness, $1963,1121 \mathrm{p} ., 4 \mathrm{pl}$; Rhode Island, p. 753-762.

1821 Availability of ground water, upper Pawcatuck River Basin, Rhode Island, by W.B. Allen, G.W. Hahn, and R.A. Brackley, 1966, 66 p., 3 pl., scale 1:24,000.

2033 Availability of ground water in the lower Pawcatuck River Basin, by J.B. Gonthier, H.E. Johnston, and G.T. Malmberg, 1974, 40 p., 5 pl., scale 1:48,000.

2062 Geohydrologic impacts of coal development in the Narragansett Basin, Massachusetts and Rhode Island, by M.H. Frimpter and Anthony Maevsky, 1979, 35 p.

2250 Rhode Island water issues, 1984, in U.S. Geological Survey, National Water Summary 1983, p. 203-205.

$2270 \quad$ Low-level radioactive ground-water contamination from a cold scrap recovery operation, Wood River Junction, Rhode Island, by B.J. Ryan and K.L. Kipp, Jr., 1985, in Selected Papers in the Hydrologic Sciences, Seymour Subitzky, ed., 1985, p. 21-33.

2270 An electromagnetic method for delineating ground-water contamination, Wood River Junction, Rhode Island, by P.M. Barlow and B.J. Ryan, 1985, in Selected Papers in the Hydrologic Sciences, Seymour Subitzky, ed., 1985 , p. $35-49$. 
Table 41. List of publications pertaining to the geology and hydrology of Rhode Island--Continued

\section{WATER-SUPPLY PAPERS (WSP)-Continued}

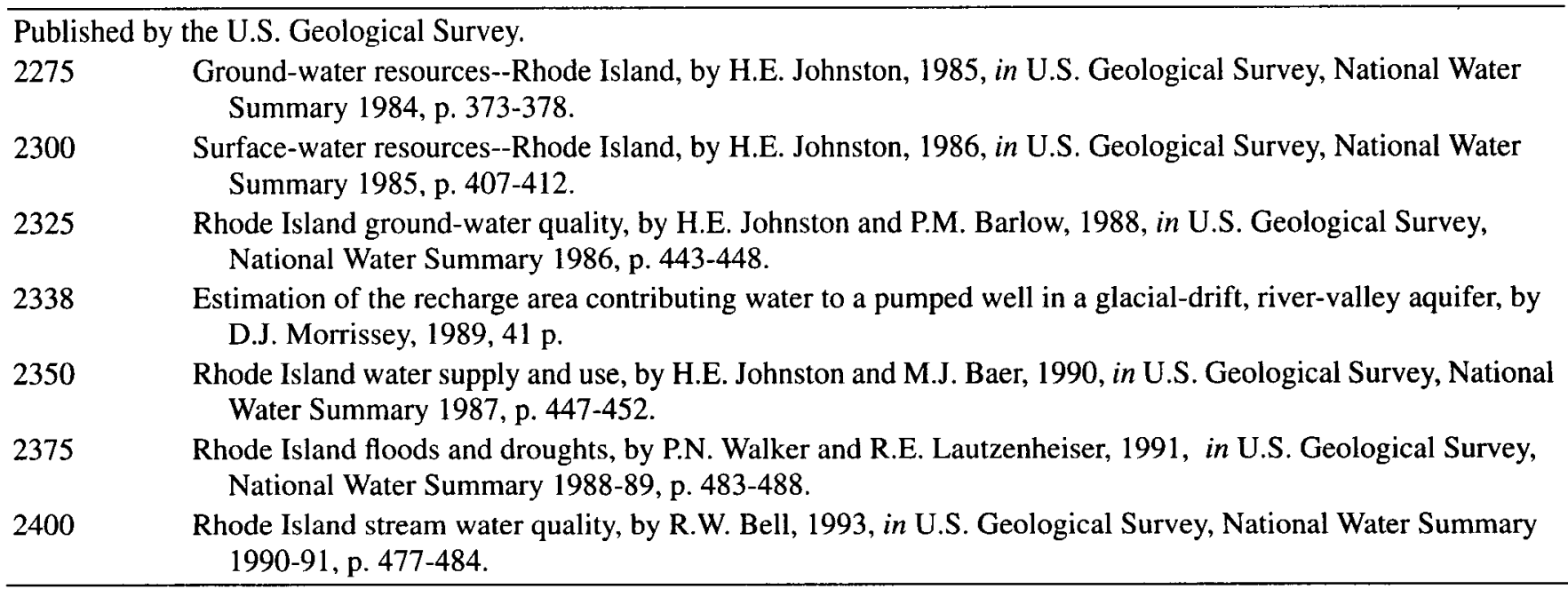

\section{GEOLOGICAL BULLETINS (GB)}

Prepared by the U.S. Geological Survey in cooperation with State agencies in Khode Island and published by State agencies. Geological Bulletins 1-3 were published by the Rhode Island Industrial Commission; Bulletins 4 and 5 by the Rhode Island Port and Industrial Development Commission; and Bulletins 6-9 by the Rhode Island Development Council. Bulletins 10-14 were published by the Rhode Island Water Resources Coordinating Board.

1 Progress report on the ground-water resources of Providence, Rhode Island, by C.M. Roberts and M.L. Brashears, Jr., 1945, 35 p., 2 pl., scale 1:31,680.

2

3

4

5

6

7

8

9

10

11

12

13

14

Well and test hole records for Providence, Rhode Island, by C.M. Roberts and H.N. Halberg, 1945, 52 p., 2 pl., scale $1: 31,680$.

The geology and ground-water resources of the Pawtucket quadrangle, Rhode Island, by A.W. Quinn, R.G. Ray, W.L. Seymour, N.E. Chute, and W.B. Allen, 1948, 85 p., 3 pl., scale 1:31,680.

The geology and ground-water resources of the Georgiaville quadrangle, Rhode Island, by G.M. Richmond and W.B. Allen, 1951, 75 p., 3 pl., scale 1:31,680.

The geology and ground-water resources of Woonsocket, Rhode Island, by A.W. Quinn and W.B. Allen, 1950, 40 p., 2 pl.

The ground-water resources of Rhode Island-a reconnaissance, by W. B. Allen, with a section on surface-water resources, by H.B. Kinnison, 1953, 170 p., 1 pl.

Ground-water resources of the Bristol quadrangle, Rhode Island-Massachusetts, by W.H. Bierschenk, 1954, 98 p., 2 pl., scale 1:31,680.

Ground-water resources of the East Greenwich quadrangle, Rhode Island, by W.B. Allen, 1956, 56 p., 2 pl., scale $1: 31,680$.

Ground-water resources of the Kingston quadrangle, Rhode Island, by W.H. Bierschenk, 1956, 60 p., 2 pl., scale $1: 31,680$.

Ground-water resources of the Providence quadrangle, Rhode Island, by W.H. Bierschenk, 1959, 104 p., 3 pl., scale $1: 31,680$.

Appraisal of the ground-water reservoir areas in Rhode Island, by S.M. Lang, 1961, 38 p., 5 pl.

Ground-water resources in the vicinity of Wallum Lake, Rhode Island, by G.W. Hahn, 1961, 34 p., 4 pl.

Geohydrological data for the upper Pawcatuck River Basin, Rhode Island, by W.B. Allen, G.W. Hahn, and C.R. Tuttle, 1963, 68 p., 1 pl., scale 1:24,000.

Ground-water resources of Block Island, Rhode Island, by A.J. Hansen, Jr., and G.R. Schiner, 1964, 35 p., 1 pl. 
Table 41. List of publications pertaining to the geology and hydrology of Rhode Island--Continued

\section{GROUND-WATER MAPS (GWM)}

Prepared by the U.S. Geological Survey in cooperation with State agencies in Rhode Island and published by State agencies. Published by the Rhode Island Water Resources Coordinating Board.

1 Wickford quadrangle, Rhode Island, by K.E. Johnson and L.Y. Marks, 1959, scale 1:24,000.

2 Slocum quadrangle, Rhode Island, by G.W. Hahn, 1959, scale 1:24,000.

3 Crompton quadrangle, Rhode Island, by W.B. Allen, K.E. Johnson, and R.A. Mason, 1959, scale 1:24,000.

$4 \quad$ East Providence quadrangle, Massachusetts-Rhode Island, by W.B. Allen and L.A. Gorman, 1959, scale $1: 24,000$.

$5 \quad$ Narragansett Pier quadrangle, Rhode Island, by G.W. Hahn, 1959, scale 1:24,000.

$6 \quad$ Hope Valley quadrangle, Rhode Island, by W.H. Bierschenk and G.W. Hahn, 1959, scale 1:24,000.

7

Fall River quadrangle, Massachusetts-Rhode Island, by W.B. Allen and D.J. Ryan, 1960, scale 1:24,000.

Coventry Center quadrangle, Rhode Island, by R.A. Mason and G.W. Hahn, 1960, scale 1:24,000.

Carolina quadrangle, Rhode Island, by A.M. LaSala, Jr., and G.W. Hahn, 1960, scale 1:24,000.

Oneco quadrangle, Connecticut-Rhode Island, by K.E. Johnson, R.A. Mason, and F.A. DeLuca, 1960, scale $1: 24,000$.

Quonochontaug quadrangle, Rhode Island, by A.M. LaSala, Jr., and K.E. Johnson, 1960, scale 1:24,000.

North Scituate quadrangle, Rhode Island, by S.J. Pollock, 1960, scale 1:24,000.

Voluntown quadrangle, Connecticut-Rhode Island, by A.D. Randall, W.H. Bierschenk, and G.W. Hahn, 1960, scale $1: 24,000$.

Watch Hill quadrangle, Connecticut-Rhode Island, by K.E. Johnson, 1961, scale 1:24,000.

Chepachet quadrangle, Rhode Island, by G.W. Hahn and A.J. Hansen, Jr., 1961, scale 1:24,000.

Rhode Island part of the Ashaway quadrangle and some adjacent areas of Connecticut, by K. E. Johnson, 1961, scale 1:24,000.

17 Clayville quadrangle, Rhode Island, by A.J. Hansen, Jr., 1962, scale 1:24,000.

18 Rhode Island parts of the Thompson and East Killingly quadrangles, by A.J. Hansen, Jr., 1962, scale 1:24,000.

19 Rhode Island parts of the Attleboro, Blackstone, Franklin, Oxford, and Uxbridge quadrangles, by K.E. Johnson, 1962, scale 1:24,000.

20 Prudence Island and Newport quadrangles, Rhode Island, by G. R. Schiner and J.B. Gonthier, 1964, scale $1: 24,000$.

21 Tiverton and Sakonnet Point quadrangles, Rhode Island, and the Rhode Island portion of the Westport quadrangle, Massachusetts, by G.R. Schiner and J.B. Gonthier, 1964, scale 1:24,000.

\section{HYDROLOGIC BULLETINS (HB)}

\section{Published by the Rhode Island Water Resources Coordinating Board.}

1 Ground-water levels in Rhode Island, 1956, by W.B. Allen and S.M. Lang, 1957, 21 p.

2 Ground-water levels in Rhode Island, 1957, by G.W. Hahn and J.A. Wosinski, 1960, 32 p.

3 Hydraulic characteristics of glacial outwash in Rhode Island, by S.M. Lang, W.H. Bierschenk, and W.B. Allen, 1960, 38 p., 1 pl.

4 Ground-water levels in Rhode Island, 1958-1959, by K.E. Johnson, 1961, 46 p.

5 Ground-water levels in Rhode Island, 1960-1962, by A.J. Hansen, Jr., and G.R. Schiner, 1963, 49 p.

6 Hydrologic data for the South Branch Pawtuxet River Basin, Rhode Island, by J.B. Gonthier, 1966, 35 p., 2 pl., scalc 1:24,000.

7 Geologic and hydrologic data for the Blackstone River area, Rhode Island, by H.E. Johnston and D.C. Dickerman, 1974, 42 p., 1 pl., scalc 1:24,000.

\section{RECHARGE-AREA REPORTS (RAR)}

Published by the Rhode Island Department of Environmental Management.

$1 \quad$ Classification and delineation of recharge areas to the Blackstone and lower Blackstone-Moshassuck groundwater reservoirs in northeastern Rhode Island, by E.C.T. Trench and D.J. Morrissey, 1985, 21 p., 1 pl., scale $1: 24,000$. 
Table 41. List of publications pertaining to the geology and hydrology of Rhode Island--Continued

\section{RECHARGE-AREA REPORTS (RAR)--Continued}

Prepared by the U.S. Geological Survey in cooperation with State agencies in Rhode Island and published by State agencies. Published by the Rhode Island Department of Environmental Management.—Continued

2

Classification and delineation of recharge areas for the Hunt ground-water reservoir in central Rhode Island, by E.C.T. Trench and D.J. Morrissey. Unpublished report, available at Rhode Island Subdistrict Office,

U.S. Geological Survey, 1 pl., scale 1:24,000.

3

Classification and delineation of recharge areas for the Chipuxet ground-water reservoir in southern Rhode

Island, by E.C.T. Trench and P.M. Barlow. Unpublished report, available at Rhode Island Subdistrict Office, U.S. Geological Survey, 1 pl., scale 1:24,000.

\section{SCIENTIFIC CONTRIBUTIONS (SC)}

Scientific Contribution 1 was published by the Rhode Island Industrial Commission;

Contributions 2 and 3 by the Rhode Island Port and Industrial Development Commission.

1 Ground-water conditions in the vicinity of Mashapaug Pond, Providence, Rhode Island, by R.M. Jeffords and W.B. Allen, 1947, $61 \mathrm{p}$.

2 Ground-water resources in the vicinity of Exeter, Rhode Island, by W.B. Allen and R.M. Jeffords, 1948, 42 p.

3 Ground-water resources of Bristol, Warren, and Barrington, Bristol County, Rhode Island, by W.B. Allen and J.A. Blackhall, 1950, 14 p., 1 pl.

\section{WATER INFORMATION SERIES REPORTS (WISR)}

Published by the Rhode Island Water Resources Board.

2 Geohydrologic data for the Chipuxet River ground-water reservoir, by D.C. Dickerman, 1976, 86 p., 1 pl., scale $1: 12,000$.

3 Geohydrologic data for the Beaver-Pasquiset ground-water reservoir, Rhode Island, by D.C. Dickerman and H.E. Johnston, 1977, 128 p., 1 pl. (2 sheets), scale 1:12,000.

4 Geohydrologic data for the lower Wood River ground-water reservoir, Rhode Island, by D.C. Dickerman and P.J. Silva, 1980, 193 p., 1 pl. (2 sheets), scale 1:12,000.

Geohydrologic data for the upper Wood River ground-water reservoir, Rhode Island, by D.C. Dickerman, R.W. Bell, K.D. Mulvey, E.L. Peterman, and J.P. Russell, 1989, 274 p., 2 pl., scale 1:24,000. 